\author{
Universidade de São Paulo \\ Instituto de Estudos Brasileiros \\ Programa de Pós-Graduação \\ Culturas e Identidades Brasileiras
}

\title{
Flores, algumas com espinhos, para o rei: \\ controvérsias acerca de d. Pedro II (1920-1940)
}

Lucas Santiago Rodrigues De Nicola

São Paulo

2014 


\author{
Universidade de São Paulo \\ Instituto de Estudos Brasileiros \\ Programa de Pós-Graduação
}

Culturas e Identidades Brasileiras

\title{
Flores, algumas com espinhos, para o rei: \\ controvérsias acerca de d. Pedro II (1920-1940)
}

\author{
Lucas Santiago Rodrigues De Nicola
}

Dissertação apresentada ao Programa de PósGraduação em Culturas e Identidades Brasileiras do Instituto de Estudos Brasileiros da Universidade de São Paulo, para a obtenção do título de Mestre em Filosofia.

Área de concentração: Estudos Brasileiros

Orientador: Prof. Dr. Stelio Alessandro Marras

São Paulo

2014 


\section{DADOS DE CATALOGAÇÃO NA PUBLICAÇÃO (CIP)}

Serviço de Biblioteca e Documentação do

Instituto de Estudos Brasileiros da Universidade de São Paulo

(C) reprodução total

De Nicola, Lucas Santiago Rodrigues

Flores, algumas com espinhos, para o rei: controvérsias acerca de d. Pedro II (1920-1940) / Lucas Santiago Rodrigues De Nicola -- São Paulo, 2014.

Orientador : Prof.Dr. Stelio Alessandro Marras.

Dissertação (Mestrado) - Universidade de São Paulo. Instituto de Estudos Brasileiros. Programa de Pós-Graduação. Área de concentração: Estudos Brasileiros. Linha de pesquisa: Brasil: a realidade da criação, a criação da realidade.

Versão do título para o inglês: Flowers, some with thorns, to the king: controversies about d. Pedro II (1920-1940).

Descritores: 1. História do Brasil 2. Historiografia 3. Primeira República (1889-1930) 4. Segunda República (1930-1964) 5. Política 6. Memória I. Universidade de São Paulo. Instituto de Estudos Brasileiros. Programa de Pós-Graduação II. Título. 


\section{$\underline{\text { ÍNDICE }}$}

Resumo, p. 7

Introdução Um arranjo de duplos, p. 9

PRIMEIRA PARTE: Pressupostos

Capítulo $1 \mathrm{O}$ itinerário da pesquisa, p. 25

Capítulo 2 Apontamentos teóricos: História e Memória, p. 51

SEGUNDA PARTE: Flores para o rei

Capítulo 3 A memória de d. Pedro II, um espectro ronda a República, p. 79

Capitulo 4 Um monarca, muitas versões (1920-1940), p. 105

4. 1. Flores sem espinhos

4. 1. 1. Carlos Magalhães de Azeredo: um imperador bastante pessoal, p. 107

4. 1. 2. Pedro Calmon: d. Pedro II, entre dois tempos e duas edições, p. 121

4. 1. 3. Max Fleiuss: um rei prometido, para uma terra prometida, p. 135

4. 1. 4. Heitor Lyra: um monumento feito de palavras, p. 146

4. 2. Flores com espinhos

4. 2. 1 Vicente Licínio Cardoso: as bases precárias, p. 172

4. 2. 2. Capistrano de Abreu: outra sorte de espinhos, espinhos do sertão, p. 186

4. 2. 3. Medeiros e Albuquerque: muito além de uma impostura literária, p. 201

4. 2. 4. Carlos Sussekind de Mendonça: o julgamento do monarca, p. 212

Em vias de conclusão, mais algumas flores, p. 229

Agradecimentos, p. 239

Bibliografia, p. 241

Obs.: Lançado em 2006, o quarto álbum da banda Devotos, grupo pernambucano de punk rock e hardcore, chama-se Flores com espinhos para o rei; o título desta dissertação foi, como se pode perceber, daí inspirado. 


\title{
RESUMO
}

A presente pesquisa consiste em, a partir da ideia de dois corpos do rei e de seus possíveis arranjos politicamente produtivos, pensar as interpretações historiográficas e as imagens literárias acerca de d. Pedro II elaboradas no Brasil, desde o começo dos anos 1920, época conturbada da vida política e cultural, até o início da década de 1940, quando se vivia, sob o governo de Getúlio Vargas, nos tempos do Estado Novo. São duas décadas carregadas de significados e memórias, nas quais se viveu a celebração e a fixação de marcos históricos para a ainda bastante jovem nação brasileira. Analisar as obras feitas neste período possibilita compreender a maneira como cada autor lidava com a ambiguidade do imperador, como cada um trabalhava, a partir de interesses específicos, o risco e a produtividade da política no monarca enfeixada. Indo além, é possível entender como cada um pensava e criticava, dessa maneira, mais do que o Segundo Reinado e seu monarca, o próprio regime republicano. A partir de apontamentos teóricos referentes às relações entre história e memória, são analisadas obras variadas, numa tentativa de mapear controvérsias que emergem em textos de gêneros diversos. Com a leitura e análise dos documentos, fica claro que a memória do imperador passou por uma série de disputas e debates, por interpretações que alternaram o tom positivo com a crítica mais satírica e corrosiva; entendimentos que, no contexto de sua produção, adquiriam eminente caráter político. Além disso, por conta de seu aspecto emblemático, muitas das questões e problemáticas levantadas no período possibilitam entendimentos amplos sobre a cultura política brasileira, inclusive de assuntos que tocam os nossos dias. Pensar essas elaborações e arranjos, seus riscos e produtividades, sua memória e longa duração, tais são os principais objetivos desta pesquisa.

\begin{abstract}
This research consists in, based on the idea of the king's double body and its political arrangements, read and analyze the historical interpretations and literary images of d. Pedro II produced in Brazil since the early 1920s, a tumultuous time of political and cultural life, until the early 1940 s, period when the country was under the government of Getúlio Vargas, in the times of Estado Novo. These two decades are full of meanings and memories; during these years, celebrations and historical marks were established for the until too young Brazilian nation. Analyze these works allows us to understand the way each author dealt with the ambiguity of the emperor, with the risk and the productivity of his policy. In this way, it is possible to understand how each author thought and criticized more than the Second Empire and its monarch, the republican regime itself. From theoretical approaches concerning the relationship between history and memory, various works are analyzed in an attempt to map out controversies that emerge in texts from various genres. This documents show clearly how the memory of the Emperor went through a series of disputes and debates; they also show how, in the context of its production, those interpretations acquired eminent political character. Furthermore, many of the problems raised in the studied period enable understandings about Brazilian political culture, including issues that reach our days. Think those elaborations and arrangements, their risks and productivity, their memory and long duration; such are the main objectives of this research.
\end{abstract}




\section{RESUMEN}

Esta investigación consiste en, a partir de la idea de los dos cuerpos del rey y de sus posibles arreglos políticamente productivos, pensar las interpretaciones historiográficas y las imágenes literarias producidas sobre d. Pedro II en Brasil, desde principios de la década de 1920, época turbulenta de la vida política y cultural, hasta el inicio de la década de 1940, cuando se vivía bajo el gobierno de Getúlio Vargas, en los tiempos del Estado Novo. Son dos décadas cargadas de significados y memorias, en las que se vivió la celebración y el establecimiento de marcos históricos para la aún muy joven nación brasileña. Analizar esas obras nos permite entender cómo cada autor lidiaba con la ambigüedad del emperador, cómo cada uno trabajaba, a partir de sus intereses específicos, el riesgo y la productividad de la política agavillada en el monarca. Al ir más allá, es posible entender cómo cada uno pensaba o criticaba, más que el que el Segundo Imperio y su emperador, la propia República. A partir de literatura vinculada a las relaciones entre historia y memoria, se analizan obras de diferentes autores, para intentar mapear las controversias que emergen en textos diversos. Autores estos que, dentro de los marcos temporales establecidos y en textos de diversos géneros, revelan visiones muy específicas acerca de d. Pedro II y del contexto en el que vivían. Con la lectura y el análisis de tales documentos, es evidente que la memoria del emperador atravesó una serie de controversias y debates; interpretaciones que alternaron el tono positivo con la crítica más satírica y corrosiva; entendimientos que, en el contexto de su producción, adquirieron un carácter eminentemente político. Además, por su aspecto emblemático, muchas de las cuestiones y problemáticas abordadas durante el período permiten un amplio entendimiento acerca de la cultura política brasileña, de temas aún presentes en nuestros días. Pensar tales elaboraciones y arreglos, sus productividades y trampas, su memoria y larga duración es el principal objetivo de esta investigación. 


\section{INTRODUÇÃO}

\section{Um arranjo de duplos}

"Restam, naturalmente, os traços físicos que poderão verificar nos quadros da família: tenho a beiçada. Minha mandíbula avança, disfarçada sob a barba há trinta e cinco anos, e minha fronte proeminente coroa uma face visivelmente côncava. Se determinismo há, prefiro este, ditado pela forma original de meu crânio, e creio mais na frenologia do sr. Lavater do que na hereditariedade austríaca. Meu rosto, tal como se apresenta, é uma alegria para os caricaturistas. Desenharam-me como uma lua crescente, como uma banana, como uma castanha de caju. Um Habsburgo, um verdadeiro, teria trancafiado os autores dessas brincadeiras de mau gosto. Deixei-os em paz, do que me gabo".

\section{Jean Soublin, em D. Pedro II, Memórias imaginárias do último imperador.}

O banana, o caju - frutas, não sem motivo, tropicais. Daquelas que, quando não bem maduras, amarram a boca de quem vai com muita vontade; daquelas, ainda, que viram adjetivos, no mais das vezes, e como se pode notar pela citação, usados para desqualificar e dar forma a brincadeiras. O beiçada com seu queixo proeminente, sintomaticamente avançado nas caricaturas e, a partir de determinada época, oculto sob a famosa, emblemática e incontornável barba - barba esta que, como para realçar a força do conjunto, embranquecera com notável precocidade. O tipo de sangue azul com posições que se entendiam como liberais. Um Habsburgo abaixo da linha do Equador, amaciado e adocicado como melaço de cana, como a infinidade de quitutes açucarados com os quais se regalava - costume que, diabético que era, sempre lhe complicou a saúde, além de carear os dentes. Não esquecer, claro, do temperamento comedido e dos conhecimentos científicos e filosóficos, da tolerância e sapiência toda deste distinto monarca, legítimo neto de Marco Aurélio, tal como teria dito, durante um comentado encontro, o escritor Victor Hugo (1802-1885). "Creio mais na frenologia do sr. Lavater do que na hereditariedade austríaca”, caso típico de polímata autodidata dos oitocentos, falante de línguas várias, algumas já mortas há bocado de tempo, praticante de astronomia e filologia, estudioso de história e geografia. ${ }^{1}$ Era de seu interesse, conforme

\footnotetext{
${ }^{1}$ De acordo com Roderick J. Barman, "D. Pedro II atingiu a vida adulta em um período em que o polímata e o sábio amador e autodidata floresciam. A experiência em uma série de campos era tão plausível quanto disseminada. A abrangência e a diversidade dos interesses literários, artísticos e científicos do imperador despertavam a admiração geral, uma vez que os monarcas da Europa se destacavam mais por seu interesse na arte da guerra, na caça e nos flertes do que na busca pelo 
gostava de dizer, ao invés de imperador, ocupar, no máximo, vaga no Senado; vontade, mesmo, era ser professor e viajar pelo mundo, livre das enfadonhas obrigações dinásticas. Um monarca que, além de símbolo sagrado e representante da nação, era também a encarnação da imagem pública do conhecimento, um sábio supostamente afastado dos interesses imediatos, desprendido de paixões políticas. Disso tudo, salta aos olhos não o imperador como um elemento estável, mas um tipo criado a partir das tramas políticas e sociais do Segundo Reinado; uma figura que tomou forma e ganhou contornos, manteve-se firme no poder e, difundida que foi, tornou-se presença corrente na historiografia brasileira e na memorialística nacional.

No trecho das "memórias imaginárias" de d. Pedro II (1825-1891), obra fictícia do escritor francês Jean Soublin - e como a ficção permite, mais ainda quando assume a primeira pessoa, certas generosidades e algumas flexibilidades que o historiador tem de olvidar -, já vem expresso muito daquilo que motiva esse trabalho: o imperador e suas interpretações, suas variadas releituras e apropriações ideológicas; da mesma forma que, consequência direta dessas múltiplas elaborações, as controvérsias e disputas em torno de sua memória e história. O foco desta pesquisa são as representações historiográficas e as imagens literárias acerca de d. Pedro II elaboradas no Brasil, desde o começo dos anos 1920, época conturbada da vida política e cultural, até o início da década de 1940, quando se vivia, sob o governo de Getúlio Vargas (1882-1954), nos tempos do Estado Novo (1937-1945) - momento no qual a pessoa de um presidente republicano atinge um alto nível de dramaticidade e de consequente elaboração memorialística, sendo capaz de estabelecer interessante diálogo com as representações do imperador. ${ }^{2}$

São duas décadas carregadas de significados e memórias; período de confluências, trata-se de um contexto de celebração e fixação de marcos históricos para a ainda bastante jovem nação brasileira. Desde 1920, os projetos de retorno dos despojos do segundo imperador e suspensão do banimento da família imperial

conhecimento. No final da década de 1840, D. Pedro II havia encontrado sua missão na vida. O conhecimento que conquistara e continuava a adquirir ele aplicaria para o benefício e o progresso de seu país. Ele se tornaria o agente da disseminação da 'civilização' (cultura europeia) no Brasil. Seria seu cidadão modelo". Roderick J. Barman. Imperador cidadão e a construção do Brasil. Tradução de Sonia Midori Yamamoto. São Paulo: Ed. UNESP, 2012, p. 178.

${ }^{2}$ Como diz Angela de Castro Gomes, em um comentário que ajuda a esclarecer este ponto, "Vargas é, não naturalmente, a primeira grande figura da República. Por dois motivos: por não ter antecedentes que o rivalizem em prestígio e por se constituir em mito, em modelo exemplar do que deve ser e fazer a autoridade presidencial, isto é, a autoridade máxima do país". Angela de Castro Gomes. "A política brasileira em busca da modernidade: na fronteira entre o público e o privado". In: Fernando A. Novais (coord.) e Lília M. Schwarcz (org.). História da vida privada no Brasil: contrastes da intimidade contemporânea. São Paulo: Companhia das Letras, 1998 (História da vida privada no Brasil, v. 4), p. 532. 
ganhavam contornos pragmáticos; entre 1922 e 1925, comemoravam-se os centenários da independência e do nascimento de d. Pedro II; em 1939 e 1940/41, atingiam-se, respectivamente, as marcas de cinquenta anos da proclamação da República, cem anos do início do Segundo Reinado e cinquenta anos da morte do imperador. Entre essas balizas temporais, que possibilitam fixar um recorte para a pesquisa, o Brasil viveu intensas mudanças, muitas das quais, por certo, escaparam aos limites das agendas políticas oficiais estabelecidas tanto pelo governo federal quanto pelos estaduais. Nos textos aqui abordados, em que história, memória e ficção - sempre respeitadas em suas particularidades, posto que, se é preciso evitar a subjugação de umas pelas outras, não se pode tomá-las como sinônimas - constituem um mesmo corpo de referências, revelam-se dois movimentos interpretativos que se cruzam e complementam. Em um sentido, decorrência do estabelecimento de marcos temporais, vários autores pensavam o Brasil em profundidade histórica, faziam novas interpretações e elaboravam balanços críticos sobre o presente; em outro, ao entender o momento presente usando o passado como referência, lançavam vistas largas e, no mais das vezes, esperançosas na direção do futuro. Assim, em tempos de, a uma só vez, celebração e crise, o passado, problematizado a partir do conflito presente, descortinava e dava corpo a possíveis futuros. A história e a memória nacional tornavam-se temas obrigatórios para realizar ações políticas e culturais; na encruzilhada do presente, quem almejava elaborar projetos para o porvir, precisava necessariamente encarar os dilemas do passado. Um momento, então, no qual a convergência entre crise e celebração, uma constante das sociedades ditas ocidentais e da modernidade, se adensava no Brasil. Afinal, como ressaltou o historiador francês Pierre Nora, com a brecha aberta pela celebração das grandes datas cronológicas, revelam-se desequilíbrios interpretativos e políticos, o que exige olhar mais de perto, de forma aguçada e combativa, a questão da memória. ${ }^{3}$

Entre os anos 1920 e 1940, o imperador vai ser, nesse intenso contexto de disputas, alvo de instigantes controvérsias. Um aspecto deve ser ressaltado de antemão: a figura de um monarca, por si só, dado o seu caráter duplo e, no caso de d. Pedro II, bastante ambíguo, é afeita a gerar polêmicas. Sendo um símbolo sagrado e representante da nação, emblema sobre-humano e homem físico, infalível e falível, o rei (juntamente com sua memória), entre concepções religiosas e políticas, caminha sobre tênue limite;

\footnotetext{
${ }^{3}$ Pierre Nora. "Présentation". In: NORA, Pierre (org). Les lieux de mémoire. Tome 1: La République. Paris: Éditions Gallimard, 1984, p. XIII.
} 
daí porque seu legado sempre pode ser disputado, criticado ou defendido a partir de fatores que, quando não bem combinados, geram discórdia. O historiador Ernst $\mathrm{H}$. Kantorowicz (1895-1963), em clássico estudo sobre teologia política medieval, tratou do tema dos dois corpos do rei; mesmo lidando com contextos bastante diversos, algumas questões levantadas por este estudioso podem servir de guia para o que está sendo tratado aqui. A ficção dos dois corpos do rei - passível de vários arranjos e novas elaborações, mas que mantém, ao longo dos tempos, um duplo fio condutor - está traçada nos relatórios do jurista Edmund Plowden (1518-1585), escritos e coligidos durante o reinado de Elisabeth, rainha inglesa do século XVI. Nesses textos, Kantorowicz encontrou, como ele mesmo define, o seu problema:

o Rei tem em si dois Corpos, a saber, um Corpo natural e um Corpo político. Seu Corpo natural (se considerado em si mesmo) é um Corpo mortal, sujeito a todas as Enfermidades que ocorrem por Natureza ou Acidente, à Imbecilidade da Infância ou da Velhice e a Defeitos similares que ocorrem aos Corpos naturais das outras Pessoas. Mas seu Corpo político é um Corpo que não pode ser visto ou tocado, composto de Política e Governo, e constituído para a Condução do povo e a Administração do bem-estar público, e esse Corpo é extremamente vazio de Infância e Velhice e de outros Defeitos e Imbecilidades naturais, a que o Corpo natural está sujeito, e, devido a esta Causa, o que o Rei faz em seu Corpo político não pode ser invalidado ou frustrado por qualquer Incapacidade em seu Corpo natural. ${ }^{4}$

O corpo político, assim, representa o "imutável no tempo", o que está fora do alcance dos súditos, aquilo que escapa à falibilidade da existência material e se arvora enquanto verdade; o corpo natural, por seu turno, é o que aproxima o rei de todas as demais pessoas, é o que, aspecto incontornável, revela seu lado humano e sujeito a paixões e mazelas, fraquezas e incoerências. ${ }^{5} \mathrm{O}$ poder de um monarca parece se apoiar precisamente na combinação desse duplo, em um arranjo bem feito e não excludente, no qual um fator sustenta, valoriza e dá sentido ao outro. Um rei, afinal, necessita de aptidão e carisma, firmeza e sutileza, força e dignidade, imanência e transcendência. Esta é uma amarração que, mesmo sendo arriscada, não deixa de ser produtiva e de dar sentido à autoridade monárquica; uma unidade de contrários que encontra estabilidade

\footnotetext{
${ }^{4}$ Ernst H. Kantorowicz. Os dois corpos do rei: um estudo sobre teologia política medieval. Tradução de Cid Knipel Moreira. São Paulo: Companhia das Letras, 1998, p. 21.

${ }^{5}$ Sobre esse assunto, Lilia M. Schwarcz comenta: “o 'corpo duplo do rei' associa de maneira excepcional o elemento transitório e humano ao corpo místico: perene, fundamento inatingível do reino. Lado a lado estão homem mortal e o rei divino, sujeitos a rituais de consagração, entre coroações, funerais, procissões e outras cerimônias da corte. É assim que, respaldada na teologia jurídica medieval, a imagem do rei se separa ao poucos da Igreja, em seu movimento de secularização, incorporando, porém, os atributos de um corpo místico". Lilia M. Schwarcz. As barbas do imperador: D. Pedro II, um monarca nos trópicos. São Paulo: Companhia das Letras, 2008, p. 28.
} 
provisória, mas que precisa, sempre, buscar novos meios de manter o equilíbrio, a legitimidade e a eficácia. Reexaminar esses arranjos de duplos para lançar luz sobre as razões que explicam o longo regime e a presença da memória de D. Pedro II, assim como a sua constante operacionalização política entre os anos do recorte, constitui um dos objetos importantes desta dissertação.

O caso do Segundo Reinado é emblemático dessa busca por novos meios de legitimidade, o que se potencializava pela história recente do país. Certa duplicidade do rei, em termos legais, era parte constituinte da própria monarquia brasileira; como notou Sérgio Buarque de Holanda (1902-1982), em "O pássaro e a sombra", livro segundo de seu Do Império à República, além de d. Pedro II ser um político habilidoso e estar sempre jogando com o poder pessoal e o apoio da "facção áulica",

a própria carta constitucional já oferece problemas embaraçosos, cuja solução se presta a infindáveis controvérsias. De conformidade com o artigo 102, para citar um exemplo, o imperador é o chefe do poder executivo e o exerce através dos seus ministros de Estado. Mas o artigo 99 declara que a pessoa do imperador é inviolável e sagrada, não se sujeitando a responsabilidade alguma. ${ }^{6}$

A situação, desde a própria Constituição, é bastante imbricada, quase fugidia. Mira-se no pássaro e o tiro vai dar com a sombra; argumenta-se sobre o corpo político e as palavras ressoam no corpo natural; critica-se a postura do chefe supremo da nação, mas ele é inviolável e sagrado; consequentemente, ao querer se equilibrar as relações entre história e memória, perdem-se os rastros seguros e encontra-se o terreno incerto e movediço - porém, bastante revelador - das diversas apropriações do passado.

Dentro desse quadro, principalmente no contexto da Guerra do Paraguai (186470), da primeira viagem de d. Pedro II ao exterior (1871) e da questão religiosa (187475), ao formular-se a atitude e a indumentária de rei-cidadão, estabeleceu-se uma situação ambígua e complexa. Ao se apegar a uma nova figura de legitimidade, a de sábio e homem de ciências, a imagem do imperador ganhava, a partir de todo o contexto no qual se inseria, um novo sentido, sobretudo no que diz respeito a seu corpo político inalcançável; as fontes de seu poder transcendente e de sua legitimidade, mesmo que

\footnotetext{
${ }^{6}$ Sérgio Buarque de Holanda. História geral da civilização brasileira - vol. 7. São Paulo: Difusão europeia de livros, 1983, p. 69. O historiador Heitor Lyra, em obra de 1939, salientara, também, esse aspecto: "De fato o Imperador não podia errar, pela ficção constitucional que o fizera sagrado e inviolável. Mas só por isso. Porque, ao contrário do Monarca inglês, ele fazia, e fazia muita coisa; não era apenas um símbolo, mas de fato o chefe supremo da nação, de fato e de direito, a primeira autoridade política e administrativa do regime". Heitor Lyra. História de Dom Pedro II. Volume II: Fastígio (18701880). Rio de Janeiro: Companhia Editora Nacional, 1939 (Coleção Brasiliana, vol. 133-A), p. 520.
} 
bem garantidas, passavam a ser mais mundanas do que sagradas. Os seus dois corpos, como nunca antes, passavam a estar concentrados num só. O imperador, ao assumir uma postura tão particular, encarava um risco; risco ainda mais evidente quando se pensa que a coroa não é - como jamais poderia ser - apenas o rei, mas um símbolo sustentado por um poder corporativo que, no limite, toca a todos, assume caráter público. ${ }^{7}$ Isso tudo é indício de que, ao acabar com uma, a figura de d. Pedro II consolidou, por assim dizer, outra imbricada e interessante assimetria. Entre tradição e modernidade, fundindo temporalidades e elementos distintos, emergia um renovado emaranhado político e simbólico. Pela Europa, é certo, havia reis que já se destacavam por sua caracterização mundana e cidadã; afinal, estar atrelado à modernidade figurava na ordem do dia, era acolher-se em um novo nicho de legitimidade. No Brasil, entretanto, antiga colônia que se tornara país independente, a relação com o mundo externo europeu e estadunidense, parâmetro de tudo aquilo que se julgava avançado e modelar, era assunto urgente da vida política e cultural; era o que fazia do rei-cidadão, sujeito curioso das coisas que estivessem na vanguarda do conhecimento mundial, um elemento formidável. Formidável, porém controverso; com essa ânsia por novidades, acabava assumindo posição central no debate político, ficava sempre no limite entre aceitação e deslocamento, admiração e repulsa: boa parte do que existe de bom se deve a ele, a seu conhecimento e cultura; boa parte do que há de ruim é culpa sua, ocorre por conta da sua alienação e alheamento dos temas nacionais. Trata-se, assim, e pensando em termos de um rearranjo do duplo corpo do rei, de uma ambiguidade que, mesmo bastante arriscada, era politicamente produtiva. ${ }^{8}$ Nesse arranjo, a política não aparece,

\footnotetext{
${ }^{7}$ Como disse Ernst H. Kantarowicz, "em muitos aspectos, a Coroa coincidia com o rei como cabeça do corpo político, e certamente coincidia dinasticamente com este, uma vez que a Coroa era transmitida ao rei por direito hereditário. Ao mesmo tempo, contudo, a Coroa manifestava-se também como um corpo composto, um agregado do rei e aqueles responsáveis pela manutenção dos direitos inalienáveis da Coroa e do reino. Como uma perpétua menor, a própria Coroa possuía caráter corporativo - com o rei como seu guardião, mas, por outro lado, não como rei isoladamente, mas como esse corpo composto de rei e magnatas que, juntos, eram referidos como a Coroa ou como seus representantes". Ernst H. Kantorowicz. Os dois corpos do rei. Op. cit., p. 220 e pp. 231-232.

${ }^{8}$ No que diz respeito às ambiguidades de d. Pedro II, Lilia Schwarcz comenta como a política do imperador era marcada por elas, sendo que, com a figura do imperador-cidadão, ele não negou os rituais e nem o poder monárquicos, e sim os suavizou. Segundo a autora, o monarca "renunciou na década de 70 ao título de soberano (porque a soberania era do povo); depois de sua primeira viagem à Europa, em 1871, deixou de lado o costume português do beija-mão; manteve a liberdade de imprensa, e rejeitou títulos e estátuas. Porém, resistiu ao debate político, compactuando com um parlamentarismo fraudulento e, apesar de afirmar-se publicamente contrário à escravidão, usou timidamente de seu poder de forma mais explícita no sentido de apressar a abolição desta. Com efeito, se o final da escravidão era matéria de maior apreensão, de toda maneira a política foi antes a de 'deixar correr, deixar passar', enquanto se caprichava, mesmo, na fachada europeizante do Império”. Lilia M. Schwarcz. As barbas do imperador. Op. cit., p. 324. Ressalte-se ainda que, ao longo de sua obra, Schwarcz aponta diversos elementos dessa
} 
ou não é percebida, como diretamente ligada ao campo dos interesses; ela é feita, em certas ocasiões, sob o manto do sagrado, em outras, sob o manto da ciência. ${ }^{9}$ São recursos e estratégias, portanto, que extrapolam a política estrito senso. A longa manutenção de d. Pedro II no poder, em algum sentido, talvez deva ser consequência da habilidade em bem jogar com essa ambiguidade; no entanto, a sua deposição se explicaria, dentre outros fatores, pelo fato de essa ambiguidade, além de não ter sido mais tão bem operacionalizada, ter perdido, enquanto articulada através da figura de um monarca, parte de seu significado e eficácia. Trata-se de um jogo de duplos, portanto, no qual risco e produtividade existem articulados, jamais separados. ${ }^{10}$

\footnotetext{
"fachada europeizante", tais como a indumentária de viés burguês do imperador, suas viagens ao estrangeiro, sua paixão pelo daguerreótipo e sua amizade com sábios europeus, assim como a participação do Brasil em algumas exposições universais.

${ }^{9}$ Sobre as articulações entre ciência e poder, o crítico literário Ivan Teixeira, em livro sobre a novela $O$ Alienista (1882), de Machado de Assis (1839-1908), mostra, por exemplo, como o conhecimento e a prática psiquiátricos só atingiram "estatuto verdadeiramente científico no Brasil quando legitimados pelo poder imperial, seja por meio de sua adoção nas escolas médicas, seja por meio de seu uso na política de estabelecimento do grande hospício do Segundo Reinado [no caso, o Hospício de Pedro Segundo, criado em 1852]. Assim, as noções de verdade, progresso, ciência e civilização fundem-se, de maneira indissociável, com a teoria e a prática do poder". Há, dessa forma, uma clara "identidade do monarca com as novas ideias científicas do tempo". Teixeira formula, nesse sentido, uma hipótese interpretativa intrigante: a de que Simão Bacamarte, o alienista da obra de Machado de Assis, seria - além de uma "alegoria humorística do núcleo de poder da ciência e da política da Corte" -, uma "paródia ou representação irônica de Pedro II em particular". Afinal, se o discurso psiquiátrico, concretizado no hospício que levava o nome do monarca, atribuía "importância essencial à Ciência, à modernidade, ao progresso e ao bem-estar coletivo, tanto mais forte será a figura do Imperador que propiciaria tudo isso e que de tudo se apropria para construir a própria imagem". Além disso, é preciso lembrar que, "muito associado à Academia Imperial de Medicina, o hospício do Imperador encontra sua contrapartida humanística no Institutito Histórico e Geográfico e no Colégio Pedro Segundo, instituições que participam do processo de disseminação da presença do Imperador pela capital do Império, solidificando a imagem do suposto compromisso com o saber e com a causa pública". Ivan Teixeira. $O$ Altar \& $o$ Trono: Dinâmica do Poder em O Alienista. Cotia: Ateliê; Campinas: Editora da Unicamp, 2010, pp. 283289. Ainda sobre as relações entre política e ciência, Lilia M. Schwarcz lembra a frase que d. Pedro costumava dizer: "A sciencia sou eu". Segundo a autora, tratava-se de uma "afirmação de claro impacto, já que constituía uma paródia à famosa expressão de Luís XIV, mas, também, o retrato fiel de um chefe de Estado que elegia a ciência como referencial, quase como modelo de conduta para um monarca célebre por sua 'rara ilustração"'. Lilia M. Schwarcz. O espetáculo das raças: cientistas, instituições e questão racial no Brasil (1870-1930). São Paulo: Companhia das Letras, 1993, p. 31.

${ }^{10}$ Acerca da perda de eficácia de d. Pedro II, Lilia Schwarcz lembra que, no período final do Segundo Reinado, várias das deficiências do monarca, antes relevadas, passavam, agora, a ser motivo para escândalos e críticas. Assim, "fazendo um paralelo com as análises clássicas de Lévi-Strauss sobre o feiticeiro, o que se pode dizer é que, quando se pergunta demais sobre a lógica das poções e cantos do xamã, é porque sua eficácia não é mais a mesma". Lilia M. Schwarcz. As barbas do imperador. Op. cit., p. 427. De acordo com Lévi-Strauss, em passagem do texto comentado pela autora, "a eficácia da magia implica a crença na magia, que se apresenta sob três aspectos complementares: primeiro, a crença do feiticeiro na eficácia de suas técnicas; depois, a do doente de que ele trata ou da vítima que ele persegue, no poder do próprio feiticeiro; e, por fim, a confiança e as exigências da opinião coletiva, que formam continuamente uma espécie de campo de gravitação no interior do qual se situam as relações entre feiticeiro e aqueles que ele enfeitiça". Claude Lévi-Strauss. "O feiticeiro e sua magia". In: Antropologia estrutural. Tradução de Beatriz Perrone-Moisés. São Paulo: Cosac \& Naify, 2012 (Coleção Portátil, 10), p. 239. Nesses "três aspectos complementares", como é possível perceber, revela-se todo o risco e produtividade do arranjo de duplos.
} 
A crítica do imperador, positiva ou negativa, parece ter sempre tratado com esse arranjo de duplos, tortuoso jogo de sombras e corpos, temporalidades e elementos que se encontram e misturam. Este é, por assim dizer, o grande tema dessa pesquisa: entender como a prática política enfeixada no segundo imperador, transitando entre imanências e transcendências muito particulares - o que, dessa forma, fazia com que ela não aparecesse explicita e puramente enquanto política, isto é, como desiderato feito de interesses e paixões -, foi operada, senão pelo próprio D. Pedro II, certamente pela memória e pela historiografia, e, mesmo que se estruturando a partir de constantes incertezas e riscos, adquiriu um caráter produtivo de longa duração na vida pública brasileira. A título de exemplo, tome-se o caso de Raul Pompeia (1863-1895), escritor anterior ao recorte temporal desta pesquisa, mas que serve como boa introdução. Entre março e maio de 1882, Pompeia publicou, em forma de folhetim, a novela As jóias da coroa, uma das mais cáusticas representações literárias de d. Pedro II e seu regime. Na esteira do crescente movimento republicano, a novela, baseada em fatos reais - o fait divers folhetinesco, no caso, se tratava do controverso desaparecimento de algumas joias guardadas na Quinta da Boa Vista -, constitui uma escandalosa crítica ao Império, ataque aguerrido e destemido; através do enfoque no episódico e no pessoal, trata-se de uma desqualificação total do monarca. A força devastadora do texto está exatamente na relação entre a escrita caricatural, as descrições sagazes e corrosivas, as situações imorais e a não identificação explícita dos personagens - Pedro II, por exemplo, emerge como o Duque de Bragantina, poderoso proprietário de terras que faz pouco caso da lei, corrompe a polícia, persegue impiedosamente seus adversários políticos e abusa sexualmente de meninas dopadas e indefesas. Se usasse os nomes verdadeiros para os personagens, certamente o folhetim não teria tanto impacto; ao ser explícito, não jogaria com a imaginação e a subversão do leitor, não faria dele parte constituinte da condenação - não alcançaria, enfim, a eficácia almejada pela crítica do escritor. A possibilidade de fazer críticas ferrenhas sem, para isso, se comprometer (mas já, evidente, se comprometendo) diretamente com a realidade, essa é a marca do texto.

O interesse na obra de Raul Pompeia, porém, transcende a pequena novela. Após o Quinze de novembro, as críticas que manifestava no que diziam respeito ao regime republicano fizeram seu ímpeto negativo em relação ao monarca perder vigor. Assim, na pena do escritor, através das diversas crônicas que escrevia, do canalha e corrupto inicial, o imperador converteu-se em vítima do conturbado processo histórico 
brasileiro. ${ }^{11}$ Pompeia é um paradigma no que diz respeito às representações de d. Pedro II, pois, além de evidenciar como crítica e elogia caminham muito próximos, deixa claro que, em grande parte das vezes, mais importante do que o próprio monarca e seu governo, é o republicanismo de quem escreve o elemento determinante na hora de interpretar o Segundo Reinado; é o republicanismo, em suma, que dá a medida do entendimento da ambiguidade. Percebe-se, em seu caso, um interessante movimento: quando o foco é o monarca e seu reinado, a crítica assume eminente caráter pessoal; quando o centro da questão é a República, o imperador é resgatado enquanto vítima de um processo histórico. Nesse jogo de variáveis, transita-se, de acordo com os interesses finais de quem escreve, do pessoal ao geral; da mesma forma, vai-se do jacobinismo exaltado à desilusão republicana. ${ }^{12}$

D. Pedro II, portanto, desde a última década do século XIX, é constantemente representado, qual seja o tema em questão, a partir da referência à República; vira, assim, uma espécie de baliza para se pensar o novo regime. Nessa lógica, em algumas representações ganha vultos de ídolo da vida pública e social brasileira; surge como um exemplo, modelo a ser louvado e seguido - conforme disse Oliveira Lima (1867-1928), d. Pedro está "entre as principais figuras morais" do século XIX, amante "da paz sem desonra e da justiça a todo custo", severo "sem arrogância" e honesto "sem limites", seu nome é caro "aos que se deixam seduzir pelos aspectos superiores da humanidade"; sem

\footnotetext{
${ }^{11}$ Leia-se, nesse sentido, a breve crônica que Pompeia escreveu em 7 de dezembro de 1891 no Jornal do Comércio, na qual tratava da morte de d. Pedro II, fato ocorrido dois dias antes, em Paris; temos, aqui, um Pompeia muito diferente daquele ardoroso e jovem republicano de dez anos antes, autor das Joias da Coroa. A começar pelo título, "O Brasil está de luto", toda a crônica é positiva no que diz respeito ao falecido: "O Brasil está de luto. A esta hora, até onde chega o alcance das comunidades telegráficas, sem distinção de opiniões políticas ou simpatias pessoais, não há um brasileiro que não lamente a morte daquele que foi para o Brasil, não um monarca, mas o Monarca D. Pedro II. O movimento histórico da emancipação nacional levou-nos à necessidade de nos separar do paternal soberano. Aqueles mesmos, porém, que personificaram a obra do destino, nessa terrível contingência, impondo-a pessoalmente ao príncipe deposto tinham o coração trespassado de mágoa. Agora aumenta-se irremediavelmente essa separação. Atenue o nosso pesar a certeza que podemos ter de que o ex-imperador morreu, sabendo que era ainda prezado daqueles que foram o seu povo, e cheio de consciência de que nos legava, como preciosa herança, um exemplo e um precedente de honestidade feita poder supremo, que fazendo o seu renome, seria para os seus continuadores, no governo do Brasil um imponentíssima lição". Raul Pompeia. As melhores crônicas de Raul Pompeia. Seleção e prefácio de Cláudio Murilo Leal. São Paulo: Global, 2011, p. 176.

${ }^{12}$ Sobre as opiniões de Raul Pompeia acerca de d. Pedro II, e de como elas mudaram ao longo do tempo, ver: Raul Pompeia. As joias da coroa. Introdução e comentários José De Nicola. São Paulo: Scipione, 2005; Sergio Goes de Paula. Um monarca da fuzarca: três versões para um escândalo na Corte. Rio de Janeiro: Relume-Dumará, 1993; Raul Pompeia. As melhores crônicas de Raul Pompeia. Op. cit, pp. 3132, pp. 81-83, pp. 116-121, pp. 177-178.
} 
maiores dúvidas, "foi o mais nobre dos homens e o mais perfeito dos monarcas". ${ }^{13}$ Trata-se, sem mais, de um rei excelente, impoluto e sublime. Tanto o é que chega às margens do paradoxo: um governante que parece negar o governo, político avesso à política. Esse, aliás, um traço que será marcante nas idealizações positivas de Pedro II: sua aparente abnegação e desprezo pelo poder, sua exaltação através de fatores que escapam da órbita política, mas que são arranjados enquanto tais. O imperador estava, assim, em posição superior quando comparado a deputados, senadores, ministros; era um ser que beirava o transcendental, dedicado ao saber e à prática da boa conduta, que não se rebaixava aos aspectos mesquinhos do debate político-partidário. A idealização e seria esta uma constante em grande parte do imaginário nacional, o que permitiria entender a ânsia pelo salvador da pátria, assim como a adesão ao militarismo ou a obseção pela corrupção em toda parte? - é sempre pelo ser que parece avesso às seduções do dinheiro e do poder, moralmente elevado, de princípios inflexíveis e não maleáveis, apartidário e incorruptível, por aquele alguém que não se modifica no curso das ações e negociações. Pelo político, em suma, que não é político. ${ }^{14}$

Nessa linha de admiração, um breve exemplo: em artigo acerca da vida e obra do pintor Pedro Américo (1843-1905), escrito no ano de 1916 e publicado na grande imprensa, Monteiro Lobato (1882-1948), preocupado que estava em discutir temas como o empreendedorismo e a liberdade de expressão no Segundo Reinado, faz o seguinte comentário:

A casa de Bragança redimia suas taras mentais e morais cumulando no monarca [d. Pedro II] virtudes que raro soem concorrer num homem só - e nas repúblicas ao molde da nossa nem numa grosa de paredros supremos. ${ }^{15}$

O autor, ao invés de fazer crítica política a d. Pedro II, elabora uma concepção específica de fazer política, focada em virtudes mentais e morais, que evidenciam o caráter único do monarca - ao que tudo indica, se distinguia de seus lamentáveis antecessores dinásticos - e repercutem no regime republicano, notadamente nos líderes paulistas embebidos por certo caboclismo imaginário e politicamente insustentável. Trata-se, como desponta dessas poucas linhas, de monarca exemplar e altivo, modelo

\footnotetext{
${ }^{13}$ Oliveira Lima. Formação histórica da nacionalidade brasileira. Rio de Janeiro: Topbooks; São Paulo: Publifolha, 2000 (Coleção Grandes nomes do pensamento brasileiro), p. 201.

${ }^{14}$ Sobre isso, lembre-se do comentário de Renato Janine Ribeiro: "Os brasileiros enxergam sua política como uma dimensão alienada, sobre a qual não têm controle. Contra ela, supervalorizam a moral do esforço e da dedicação - mas que, apesar de tudo, é apenas uma moral. Imaginam que seja possível conduzir a sociedade sem política". Renato Janine Ribeiro. "O Brasil pela novela". In: A sociedade contra o social: o alto custo da vida pública no Brasil. São Paulo: Companhia das Letras, 2000, p. 136.

${ }^{15}$ Monteiro Lobato. "Pedro Américo". In: Ideias de Jeca Tatu. São Paulo: Globo, 2008, p. 83.
} 
perdido de governante, contraposto notório aos dirigentes capciosos do novo regime. A crer nessa leitura, após a proclamação da República, a vida política brasileira fora desvirtuada, estavam perdidos os dias áureos do bom governo. Agora era tecer memória louvável, lamentar o que já se fora e exaltar o exemplo de Pedro II.

Noutras representações, entretanto, o monarca é perniciosa influência, baliza a ser rompida e superada; por essa perspectiva, ao trazer à baila a memória do imperador, é necessário livrar-se desse espectro que nos assombra. Nessa linha de entendimento, ou ele fica confinado no passado, bem guardado nos dias de ontem e longe das reverberações saudosistas, ou emerge no presente para ser alvo de interpretações sugestivas, chacotas e pilhérias. Algumas até bastante bem humoradas e elaboradas a partir de um refinado jogo de imagens. É o caso da frase imaginária que Paulo Mendes Campos (1922-1991) coloca na boca do imperador (o escritor costumava escrever frases que personalidades históricas poderiam ter dito em situações inusitadas): Se ao menos houvesse um estádio aqui perto, o domingo não seria tão aborrecido - Dom Pedro II em São Cristóvão. ${ }^{16}$ Com sua brincadeira, algo corriqueira e aparentemente despretensiosa, Paulo Mendes Campos provoca uma desconfiança e, através disso, revela os riscos da ambiguidade do monarca. A graça da "frase que poderia ter sido dita" - e perceba-se, algo intrigante, como a brevidade e o estranhamento abrem margens para variadas interpretações - não reside no anacronismo da situação ou, até mesmo, em seu absurdo; está no inusitado e na carga de sentidos subentendidos. À semelhança de figuras como Oswald de Andrade (1890-1954) e Murilo Mendes (19011975 ) - autores que serão abordados ao longo desta pesquisa -, Paulo Mendes Campos opera com a história, ressignifica o passado e toma d. Pedro II a partir de uma colocação fundada sobre o humor. O cerne de sua blague está no deslocamento dessa figura entediada, cansada da vida palaciana e da poeira dos livros. Nessa linha de pensamento, o imperador emerge, então, e levando a sério a piada da frase que poderia ter sido dita, como um ser enfadado e desejoso de romper com os limites de sua vida sem emoções, de sua rotina pautada em livros e obrigações; um rei que, ao invés de ser legitimado por sua ciência e sabedoria, encontra nisso tudo uma chateação. Talvez, indo um pouco mais além, seja possível reconhecer nessa frase um d. Pedro que gostaria de experimentar algo de novo, pois se vê incapaz de levar adiante seu arranjo de duplos -

\footnotetext{
16 Paulo Mendes Campos. Alhos e bugalhos: crônicas humorísticas. Rio de Janeiro: Civilização Brasileira, 2006, p. 195.
} 
lembre-se que em algumas de suas crônicas, numa nítida evidência dos riscos de se tomar a sabedoria como um fator de legitimidade, Mendes Campos retrata o monarca como autor dos "piores sonetos da língua portuguesa", cultor de "virtudes que podiam ser banidas da nossa formação, virtudes bastante monótonas ou bobocas". ${ }^{17}$ Pensar o monarca, esse cultor de letras e versos, em um estádio de futebol se torna algo tão inusitado quanto o imperador na cadeia, tal como quis Oswald de Andrade no seu poema "Senhor Feudal". A graça da frase que poderia ter sido dita é que o entediado monarca, apesar de lá querer ir, não combina com o estádio, não vai para o meio da gente, não vibra nas arquibancadas e nem festeja a alegria dos gols. Simplesmente, é algo muito estranho para ser plausível. É como se, no caso de d. Pedro II, a legitimidade garantida pelo conhecimento passasse a tudo dominar e não deixasse margens para alternativas; como se o aspecto apolítico tivesse se sobreposto ao político; a transcendência à imanência. Com isso, rompe-se o equilíbrio, emergem a vaidade e o enfado de um monarca dedicado à ciência e ao saber. Desponta a caricatura. ${ }^{18}$

Cada representação feita do imperador, portanto, não constitui apenas mero jogo de imagens e figuras; pelo contrário, são tramas e tessituras elaboradas a partir de escolhas e, consequentemente, carregadas, mesmo as mais modestas, de sentidos históricos e significados político-sociais. Feitas a partir do intricado arranjo de duplos, são interpretações controversas de nosso passado nacional, versões que vão ganhando, no momento em que foram criadas e divulgadas, formas, filiações, contornos ideológicos. Pautadas em referências comuns e em processos sociais, são noções engajadas que, como parte constituinte do jogo político e memorialístico, tornam-se constantes e produtivas.

\footnotetext{
17 As crônicas são "Brasil brasileiro" e "História do Brasil", ambas pertencentes ao livro Brasil brasileiro: crônicas do país, das cidades e do povo. Organização de Flávio Pinheiro. Rio de Janeiro: Civilização Brasileira, 2005, pp. 15-17 e pp. 23-24.

${ }^{18}$ Sobre a frase criada por Paulo Mendes Campos e que d. Pedro II poderia ter dito, ainda uma observação - ou outra tentativa de interpretação. A Quinta da Boa Vista, localizada no bairro de São Cristóvão, fica a meio caminho entre os dois estádios mais importantes, ao menos em termos de tamanho e reconhecimento, da cidade do Rio de Janeiro: o de São Januário, inaugurado em 1927 e local de importantes comícios de $1^{\circ}$ de maio durante o Estado Novo; e o Maracanã, monumental estádio inaugurado em 1950, por ocasião da Copa do Mundo realizada no mesmo ano. Ou seja, pode-se imaginar que, desejoso de ir a assistir um jogo de futebol, d. Pedro II ficaria dividido entre, por um lado, a herança lusitana (afinal, São Januário pertence ao Clube de Regatas Vasco da Gama) e o local favorito das manifestações populistas de Getúlio Vargas; e, por outro, o estádio que, além de grande palco popular, é símbolo de um Brasil grande, moderno e aberto ao mundo. Dividido, portanto (tal como é o caso de Vargas em seus dois governos, e talvez seja esse o foco indireto de Paulo Mendes Campos), entre a tradição ibérica e a modernidade cosmopolita, entre o populismo autoritário e a democracia liberal.
} 
Essa pesquisa está dividida em quatro capítulos, encerrados em duas partes: Pressupostos (capítulos 1 e 2) e Flores para o rei (capítulos 3 e 4).

No primeiro capítulo, há o que chamei de itinerário da pesquisa, no qual tentei esclarecer o percurso que me levou à formulação dos problemas abordados. Este é um trajeto que, como não poderia deixar de ser, partiu de um diálogo com a bibliografia mais recente e difunda sobre $\mathrm{d}$. Pedro II para, daí sim, chegar ao recorte e às fontes - os rastros de muitos dos autores trabalhados nesta dissertação, assim como muitas das indagações e questionamentos, foram estabelecidos, como se verá, a partir da leitura das obras comentadas neste capítulo.

No segundo, trato de questões teórico-metodológicas ligadas às relações entre história e memória; este é um tema que, caro à historiografia, apareceu frequentemente ao longo da pesquisa e demandou maior atenção. Optei por fazer uma leitura esmiuçada da obra de três autores, de épocas e áreas diversas; tal procedimento permitiu entender como, ao invés de tomar memória e história a partir de uma oposição, talvez seja mais produtivo entendê-las, através de certo equilíbrio garantido pelo próprio objeto de estudo, enquanto relacionadas e complementares. Isso possibilita que textos de diferentes gêneros possam ser utilizados como fontes de um trabalho comum, sem que para isso tenham de ser hierarquizados e discriminados em suas especificidades. Dessa forma, é possível mapear com maior riqueza e diversidade as controvérsias que surgem a partir dos mais variados escritos sobre d. Pedro II.

No terceiro, trato de forma mais abrangente a maneira como a memória de $\mathrm{d}$. Pedro II foi, entre os anos 1920 e 1940, elaborada e disputada no regime republicano.

No quarto, foco alguns intérpretes não abordados nos capítulos anteriores. Estes são autores que, dentro do recorte temporal proposto e em textos dos mais variados gêneros, revelam visões bastante específicas acerca de d. Pedro II. São eles: Carlos Magalhães de Azeredo, Pedro Calmon, Max Fleiuss, Heitor Lyra, Vicente Licínio Cardoso, Capistrano de Abreu, Medeiros e Albuquerque e Carlos Sussekind de Mendonça. Os critérios de seleção das obras e autores foram os seguintes: esses são autores que dão conta de uma boa diversidade de opiniões, além de não serem - exceto, talvez, os casos de Capistrano de Abreu e Pedro Calmon - constantemente abordados pela historiografia; são textos publicados entre 1920/40; são obras nas quais os autores 
demonstram intenso envolvimento com o assunto, não se fazendo de rogados no momento de tecer comentários, seja a favor ou contra o monarca. Optou-se por usar somente textos que, mesmo tendo aparecido anteriormente em revistas ou periódicos, foram publicados e circularam, entre os anos do recorte temporal, no formato de livro; um critério que, se não resolve todos os problemas no trato da documentação, ao menos permite um controle maior sobre as fontes e não impede a constatação da diversidade de opiniões - o que por si só já é um fato interessante, pois revela que argumentos favoráveis e contrários ao imperador transitavam, às vezes, em meios muito próximos. 


\section{Primeira parte}

\section{Pressupostos}




\section{CAPÍTULO 1}

\section{O itinerário da pesquisa}

"Como deve ser doce granjear o sorriso dos pobres, os vivas de uma multidão, o amor de um povo! A história julga os resultados, é claro, mas onde estão suas recompensas? Devo contentar-me com os elogios de um compêndio do próximo século? A própria ideia de que um escrevinhador do futuro tencione esquadrinhar minha vida e compreender o meu pensamento horripila-me".

\section{Jean Soublin, em D. Pedro II, memórias imaginárias do último imperador}

Tão importante quanto a pesquisa em si, enquanto trabalho intelectual e produto de conhecimento, é o itinerário que ela seguiu, desde o momento de sua concepção, até a elaboração dos resultados finais. O itinerário desta pesquisa foi tortuoso - como, suspeito, sejam os de todas - e marcado por diálogos dos mais interessantes. Um aspecto, porém, foi fundamental: as indagações acerca da história e memória de d. Pedro II partiram sempre do tempo presente, de documentos e problemas pertencentes aos dias atuais. Por conta disso, o percurso que levou - com seus constantes equívocos de rota e eventuais acertos de direção, excessos de paixão e esforços de moderação - ao recorte dos anos 1920 a 1940 passou pela leitura da bibliografia mais conhecida e recente feita sobre o imperador, principalmente as biografias, para, daí sim, lançar atenções sobre o passado. Se aparecem, neste texto, autores tão diferentes quanto Carlos Magalhães de Azeredo, Sussekind de Mendonça, Max Fleiuss, Capistrano de Abreu, dentre outros, é preciso esclarecer a tessitura que os aproximou - dessa maneira, talvez, possa ser possível entender como esses autores conseguem ser, a um só tempo, tão parecidos e tão controversos. Esse movimento é fundamental, constitui o cerne da pesquisa, esclarece o seu feitio e a sua razão; afinal, foram as críticas e admirações suscitadas pelo presente e pelas paixões atuais que abriram o caminho para as críticas e admirações rastreadas no passado. Sem essa transição de temporalidades, a história não seria feita enquanto esforço interpretativo, e sim enquanto reverberação passadista. Além do mais, como bem alertou Peter Gay, "a paixão, famosa como a ameaça mais prejudicial do historiador, pode se tornar seu bem mais precioso. Nem toda consciência é falsa consciência". 19

\footnotetext{
${ }^{19}$ Peter Gay. O estio na história: Gibbon, Ranke, Macaulay e Burckhardt. Tradução de Denise Bottmann. São Paulo: Companhia das Letras, 1990, p. 179.
} 
O mote desta pesquisa surgiu no último semestre da graduação, mais precisamente durante a elaboração do trabalho final para o curso de Ensino de História - Teoria e Prática, ministrado pela professora $\mathrm{Dr}^{\mathrm{a}}$. Antônia Terra, no Departamento de História da Faculdade de Filosofia, Letras e Ciências Humanas da Universidade de São Paulo. A proposta da atividade final era conceber uma sequência didática (algo como uma série de aulas focadas em problematizar determinado tema a partir de documentos diversos) para turmas de ensino médio. A partir de um documento de nossa época retirado de uma revista de grande circulação, Veja, e motivo, ao menos para mim, de grande estranhamento -, o objetivo era abordar a temática do Segundo Reinado e da imagem veiculada de d. Pedro II. O passo seguinte foi contrapor o artigo jornalístico selecionado a um texto de matiz completamente diverso, mas que, necessariamente, fizesse referência ao imperador; o documento escolhido foi, naquele momento, a poesia "Senhor feudal", de Oswald de Andrade. Aquele trabalho se baseava, da mesma forma que este, na premissa de que toda pesquisa histórica tem de partir de problemas e inquietações, ser uma história-problema, questionadora e crítica, com preocupações e sentidos que alcancem o momento presente. Uma pesquisa que se limite a ser exercício de erudição ou mera especialização, não teria motivos e nem justificativas aceitáveis.

Dois foram os pontos iniciais, as problemáticas primeiras que pautaram a elaboração da sequência didática:

a) Seria d. Pedro II um paradigma de governante para a República brasileira? $\mathrm{Ou}$, em outras palavras, teria sido o Segundo Reinado, com seu monarca à frente, o ápice da formação nacional brasileira, um processo que teria entrado em decadência após o Quinze de novembro?

b) A partir de todas as acirradas disputas por d. Pedro II no período republicano, sob quais aspectos o monarca foi resgatado? Quais imagens dele foram elaboradas?

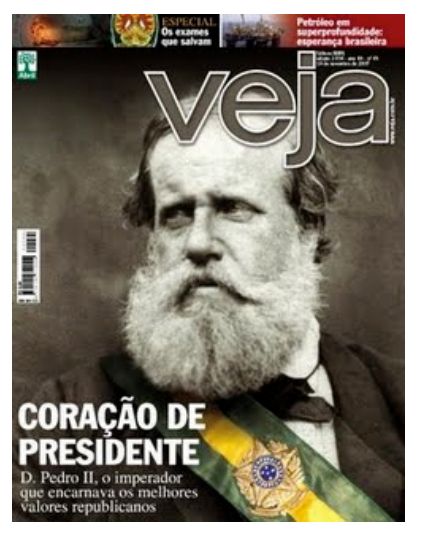

Capa da revisa Veja, edição de 14 de novembro de 2007. 
A reportagem, assinada por Vilma Gryzinsky - à época, editora-executiva da revista $V e j a$-, deixa claro como a figura de d. Pedro II é constantemente reinterpretada de acordo com os posicionamentos políticos de quem escreve sua história. A começar pela própria data de publicação - véspera do feriado de Quinze de novembro -, o texto revela aspectos intrigantes e controversos. Na capa, Pedro II aparece trajado na famosa casaca de "monarca-cidadão" e, em verde e amarelo, contrastando com o branco e preto da foto, uma faixa presidencial atravessada no peito. No correr da leitura, nos deparamos com observações como a seguinte:

De todas essas características [de d. Pedro II], a mais surpreendente é a fé republicana. Como um monarca, de coroa, cetro e manto, além de mais poderes constitucionais do que sua prima e contemporânea, a rainha Vitória (o Poder Moderador, mas não falemos nisso para não lembrar dos tempos de escola), poderia defender um sistema de governo que implicaria sua própria extinção? Em defesa da tese republicana, pesam escritos do próprio Pedro II. "Nasci para consagrar-me às letras e às ciências, e, a ocupar posição política, preferiria a de presidente da República ou ministro à de imperador", escreveu numa espécie de autorretrato feito em 1861 no diário habitualmente dedicado a registrar fatos mais rotineiros. ${ }^{20}$

Para parte da boa sociedade brasileira, a quem a leitura da revista em questão é elemento constante de informação, está redivivo o fantasma que assombrou a República. Como ressalta Gildo Marçal Brandão, para determinados grupos conservadores, o Império, principalmente o Segundo Reinado, funciona "como uma espécie de idade do ouro da política". ${ }^{21}$ Ainda mais se o monarca for uma figura neutralizada, letrada e zelosa. O fenômeno, contudo, não é de hoje; a antropóloga Regina Abreu, estudando as relações entre memória e história que estiveram na base da formação, em 1922, do Museu Histórico Nacional - cujo projeto expositivo, coordenado por Gustavo Barroso (1888-1959), deu amplo destaque ao período imperial, principalmente ao reinado de d. Pedro II -, já identificava essa valorização do Império, que surgia como grande formador da nacionalidade brasileira:

O culto do passado implicava uma visão nostálgica do passado, onde alguns momentos eram especialmente glorificados em detrimento de outros. Ao período do Império corresponderia um passado tranquilo e magnífico. A civilização nos trópicos brasileiros teria sido aquisição da nobreza brasileira,

\footnotetext{
${ }^{20}$ Vilma Gryzinsky. "O rei e nós”, In: Veja, edição no 2034, 14 de novembro de 2007, p. 111. (Texto disponível em versão digital no site $\underline{w w w . v e j a . a b r i l . c o m . b r) ~}$

${ }^{21}$ Gildo Marçal Brandão. "Linhagens do pensamento político brasileiro", In: Dados-Revista de Ciências Sociais, Rio de Janeiro, Vol. 48, n 2, 2005, p. 256 (texto consultado em www.scielo.com.br).
} 
consolidada durante o reinado de D. Pedro II, o monarca esclarecido e culto. ${ }^{22}$

Nessa toada, em que vigora efetivo culto do passado - e vamos sem muito exagero, para não lembrar as chatas aulas de História -, d. Pedro II emerge como o republicano avant la lettre, abolicionista convicto, sujeito ilustradíssimo, entusiasta das ciências, mecenas das artes, esclarecido e culto. Figura admirável, o imperador, como vem dito no texto da reportagem, "tinha opiniões honrosas sobre praticamente todos os assuntos importantes. Era a favor de eleições livres e ardoroso defensor da educação como instrumento democrático". ${ }^{23}$ É importante elucidar como a autora do artigo, ao mesmo tempo em que vangloria as preocupações de d. Pedro II com a democracia e a educação, não tece nenhuma reflexão acerca da forma como se davam as eleições no Segundo Reinado e sobre quem eram as pessoas capazes de usufruir e frequentar as instituições de ensino. Ou seja, não há a menor preocupação em criar perspectivas, em projetar densidade histórica nos temas abordados. O problema a ser colocado, ao menos aqui, não é tanto o fato de um monarca ser republicano, ou de o imperador de uma nação escravocrata se dizer abolicionista (afinal, a história comporta algumas contradições das mais espantosas, que devem sempre ser questionadas e pensadas criticamente). ${ }^{24} \mathrm{O}$ grande problema é o uso que se faz dessas informações, a maneira de abordá-las e difundi-las. O texto publicado na revista Veja, ao se basear em estereótipos e lugares comuns, tratando assuntos complexos sem a devida densidade histórica, termina por naturalizar uma imagem positivada de d. Pedro II. Costura, com notável interesse político, tudo aquilo que é ambíguo e dúbio, que é motivo de disputa e debate.

No Brasil, o voto, por exemplo, apesar de avançado quando comparado a outros lugares, era censitário e pautado nas propriedades materiais, o que fazia o grosso dos

\footnotetext{
${ }^{22}$ Regina Abreu. A fabricação do imortal: memória, história e estratégias de conservação no Brasil. Rio de Janeiro: Rocco: Lapa, 1996, p. 187.

${ }^{23}$ Vilma Gryzinsky. "O rei e nós". Op. cit., p. 112.

24 Além do mais, quando se trata de política, não estão em questão as "opiniões honrosas sobre os assuntos importantes" que os governantes possam ter. Mesmo tratando de um contexto distinto (o autor não fala de uma monarquia), lembro as palavras de André Singer, que podem ser esclarecedoras: "Por definição, o dirigente político não é autêntico, pois representa algo geral. O seu papel é condensar os pontos de vista da unidade política que lidera, desde uma facção partidária, um partido inteiro, uma região, até um país. Em qualquer hipótese, não cumprirá bem a função para a qual foi destinado se decidir simplesmente dizer o que 'verdadeiramente' pensa sobre cada assunto. Creio até que aquilo que ele 'verdadeiramente pensa' pode não ser importante, a menos que venha a influenciar decisões, o que por vezes ocorre, mas não é comum. Daí deriva uma questão delicada: como satisfazer a exigência de transparência que acompanha a democracia com a verificação empírica de que a política real é sempre uma arte de 'representação'?" André Singer. Os sentidos do lulismo: reforma gradual e pacto conservador. São Paulo: Companhia das Letras, 2012, p. 243.
} 
envolvidos no processo eleitoral participar enquanto votantes, e não eleitores. Richard Graham vai além e ressalta que as eleições eram controladas pelo jogo político imperial, sendo que o partido colocado no gabinete pelo monarca certamente ia ter sempre a maioria do Congresso no pleito seguinte. Em uma abordagem bastante original, o historiador entende que, mais do que efetivo sufrágio, as eleições cumpriam uma função social, posto que reafirmavam hierarquias, autoridades e poderes locais. Tudo isso feito em meio a um cenário teatral, efetiva performance dramática, lição visual de poder afeita a um público majoritariamente analfabeto e em constante movimentação geográfica. ${ }^{25}$ A partir da problematização histórica, por breve que seja, fica notório, no texto da reportagem, como ocorre uma deliberada simplificação, uma elaboração de estereótipos que não revela a complexidade do tema abordado. D. Pedro II, em nenhum momento, parece ser entendido enquanto figura política lançada em seu contexto; não há uma distinção entre o indivíduo e a pessoa, o detalhe e o geral, o objetivo e o subjetivo. A relação entre memória e a história não é, assim, problematizada e pensada em sua complexidade. Mesmo que se entenda o monarca como um democrata, qual era sua margem de ação, quais suas possibilidades? Mais ainda, qual a noção de democracia vigente no Brasil da segunda metade do século XIX?

Com essas indagações, entretanto, não se quer dizer que seja legítimo tomar tudo em separado; o arranjo de duplos não pode ser simplesmente desfeito ou ignorado. Uma face está invariavelmente ligada e arvorada sobre outra: o homem não se separa do imperador, a admirável figura humana não escapa à instigante figura política. Uma complexidade não pode anular a outra, não pode redundar em nova simplificação. $\mathrm{O}$ dilema está concentrado na maneira de fazer a abordagem. Nelson Werneck Sodré (1911-1999), em obra de 1939, já lançava luz ao problema:

[D. Pedro II] era um bom, com certeza, porque protegeu outros indivíduos, menos afortunados. Era um justo - mas um justo doméstico. Exemplar chefe de família, educador correto dos filhos, simples no trato dos demais - virtudes de homem particular. A auréola que o cerca não se apoia senão nessa moral individual rígida e pura. Ela será o derradeiro entrave para a república. Mas do homem público, do chefe de um regime, que gesto de lucidez conhecemos que o faça grande na marcha dos acontecimentos? ${ }^{26}$

\footnotetext{
${ }^{25}$ Richard Graham. "O teatro da eleições no Brasil imperial". In: Stelio Marras (org.). Atualidade de Sérgio Buarque de Holanda. São Paulo: Edusp / Instituto de Estudos Brasileiros, 2012, pp. 133-150.

${ }^{26}$ Nelson Werneck Sodré. Panorama do segundo império. Rio de Janeiro: Ed. Graphia, 1998, p. 127.
} 
Ainda nesse mesmo Panorama do Segundo Império, Sodré fez aquela que, até então, era uma das mais contundentes apreciações a respeito da historiografia sobre d. Pedro II:

[O imperador] não foi estudado ainda por quem quisesse ou pudesse situá-lo no ambiente do seu tempo. O quadro apresentá-lo-ia, então, emoldurado pela agitação e pelos acontecimentos de seu tempo. A figura ressaltaria, em linhas precisas, justamente desse contraste e desse confronto com o panorama político e social que o cercou. Tendo influído pouco no desenrolar dos eventos, ele sofreu, entretanto, fundamente as influências desses eventos. Era humano e, conquanto pretendesse viver à margem da torrente, ela o dominou e conduziu - assoberbou-o por vezes. ${ }^{27}$

A observação retratava com precisão aquilo que fora a tônica oficiosa dos estudos sobre o monarca e aquilo que era preciso mudar. Ao mesmo tempo em que toma d. Pedro II como humano, como sujeito condicionado por uma criação rígida e pelo exercício precoce do poder, Sodré lança-o na esfera do mundo público, ressalta que, para além de fatores biográficos pessoais, o homem era também imperador e, como tal, enfeixava imenso poder e responsabilidades em suas mãos. Não se pode entendê-lo somente a partir de "poses", "através das anedotas e da história dos pequenos episódios em que se envolveu"; ${ }^{28}$ para o historiador, mais do que saber se tecia belos comentários a favor da abolição, gostava de ciências e lia muitos e volumosos livros, é preciso encarar o monarca como representante máximo do Estado brasileiro. Além de escrever nas margens dos textos, fez algo com os assuntos e com as ideias, atuou no mundo que o cercava? Seguindo tal linha de pensamento, é possível desvendar, ao fazer questões desse tipo, como era produtiva a ambiguidade sobre a qual o imperador se legitimava.

Note-se ainda uma questão fundamental e reveladora acerca da historiografia sobre d. Pedro II: Nelson Werneck Sodré escreveu o seu Panorama no momento em que se aproximavam os cem anos de Segundo Reinado e os cinquenta da morte do monarca, época em que surgiam importantes e volumosas biografias de d. Pedro II, tais como as escritas por Pedro Calmon (1902-1985) e Heitor Lyra (1893-1973). Por conta disso, a obra de Sodré tem um eminente aspecto de balanço e revisão; com seus capítulos curtos e propositivos, é um panorama amplo, conjunto de diversas - e, quando da publicação do livro, ainda abertas - críticas, questões e proposições. Uma delas, entretanto, merece destaque: ao longo de toda obra, o autor denuncia os excessos centralistas do Segundo Reinado - "o segundo império foi apenas o panorama de uma

\footnotetext{
${ }^{27}$ Nelson Werneck Sodré. Panorama do segundo império. Op. cit., p. 126.

${ }^{28}$ Nelson Werneck Sodré. Panorama do segundo império. Op. cit., p. 134.
} 
centralização total e enorme", "a centralização foi o império" 29 -, que debilitavam todo resto do país para satisfazer os interesses das oligarquias escravocratas e cafeeiras. $\mathrm{O}$ colapso do regime imperial, segundo Sodré, se deu quando o centralismo atingiu seus limites de tensão e uma elite letrada, porém afastada dos centros de decisão, conquistou espaço na vida pública; quando, portanto, se debilitaram, ainda mais, os fracos alicerces da monarquia. Não é de espantar que uma das personalidades mais admiradas pelo autor seja Aureliano Tavares Bastos (1839-1875), figura sempre lembrada, ao longo do texto, enquanto impopular e solitária, um político empenhado na defesa do federalismo e no diagnóstico da "apoplexia do centro e paralisia nas extremidades" - essa, aliás, uma constante: os intérpretes críticos de d. Pedro II, na maior parte das vezes, tecem loas a Tavares Bastos.

Inevitável entender, nessa linha de pensamento, como a realidade vivida e a experiência presente interferiram diretamente na interpretação que Sodré elaborou sobre o Segundo Reinado. Ao fim da década de 1930, no contexto do Estado Novo, vivia-se, de forma autoritária e antidemocrática, um cenário de clara centralização política. Além do mais, Getúlio Vargas se aproximava deliberadamente de d. Pedro II, não só pela predominância na paisagem política, mas pelo próprio culto do passado. Em 1943, iria ser criado o Museu Imperial; antes disso, em 5 de dezembro de 1939 - o monarca falecera exatos 48 anos antes, em 5 de dezembro de 1891 -, com todas as pompas de uma cerimônia oficial, fora inaugurado o mausoléu imperial de Petrópolis. Era um momento em que, através da exaltação memorialística, passado e presente se aproximavam para celebrar o Estado nacional; como ressalta Roderick Barman, "a participação do chefe de Estado no novo sepultamento do imperador sinalizou a total reabilitação de D. Pedro II como governante e a plena aceitação de seu reinado como parte do passado da nação". ${ }^{30}$ A esse respeito, lembre-se do que disse o historiador Max Fleiuss (1868-1943), eminente membro do Instituto Histórico e Geográfico Brasileiro (IHGB), em Alocução proferida no dia da inauguração do mausoléu:

\footnotetext{
${ }^{29}$ Nelson Werneck Sodré. Panorama do segundo império. Op. cit., pp. 270-271.

${ }^{30}$ Roderick J. Barman. Imperador cidadão e a construção do Brasil. Op. cit., p. 573. Sobre o mausoléu e a aproximação de Vargas a d. Pedro II, escreveu Lilia Schwarcz: "Foi só em 5 de dezembro de 1939, com a presença do presidente Getúlio Vargas, que se inaugurou a capela mortuária em Petrópolis. Sobre o túmulo esculpido por Leão Veloso estendiam-se os corpos de d. Pedro II e da imperatriz, feitos em mármore. À frente, os vitrais (segundo desenho de Carlos Oswald) representavam a ascensão e queda do reinado. Mais ao lado o poema-lamento de d. Pedro, o qual pede 'a justiça de Deus na voz da História'. Nesse cenário, ideal para o teatro de consagração, eis que d. Pedro, pelas mãos de um presidente forte como Getúlio Vargas, volta como um rei popular, um herói nacional, que como tal não tem nem data, nem local, nem condição". In; Lilia M. Schwarcz. As barbas do imperador. Op. cit., p. 513.
} 
A pátria brasileira - a República, para integrar definitivamente na alma nacional os nossos últimos soberanos, fez erigir-lhes aqui, no recinto sagrado da cidade serrana, que eles tanto amaram - a cripta - que exprime o coração do povo brasileiro.

Ante a dupla majestade da morte e da realeza do monumento, vai descobrir-se, reverente e grato, o Brasil do Estado Novo, na pessoa do primeiro e insigne magistrado, o sr. Getúlio Vargas, a quem se deve, sob múltiplos aspectos, a inauguração do mausoléu de piedade cristã e do mais puro sentimento patriótico.

$[\ldots]$

A nação - a que ele [d. Pedro II] chamava - a sua grande família brasileira - e o governo da República nova, do Brasil forte, cada vez maior em nome do passado, do presente e da posteridade, glorifica o Brasil, exprimindo hoje seu julgamento definitivo sobre a figura do Magnânimo e de d. Teresa Cristina. Assim revela a justiça que ele aguardou sereno na sublimidade do seu famoso verso: A justiça de Deus na voz da História. ${ }^{31}$

Nelson Werneck Sodré, ao que tudo indica, estava bem consciente dessa operação com o passado; através de d. Pedro II - a quem, na mesma Alocução, Max Fleiuss tão sugestivamente chamou "figura messiânica do estadismo brasileiro" 32 - e do Segundo Reinado, transita entre temporalidades, entre questões que perpassam a história política do Estado nacional brasileiro, mas o faz na contramão do culto da memória. Seu Panorama do Segundo Império, acima de tudo, revela como não havia um consenso no que dizia respeito a d. Pedro II, assim como não deixa dúvidas acerca da presença do monarca na vida política brasileira de então - note-se como Max Fleiuss se exprime em termos de "dupla majestade", da morte e do monumento. O debate sobre a memória, o culto do passado e a escrita da história emergem, assim, como elementos fundamentais de prática política.

Dessas leituras iniciais, pode-se inferir um apontamento que servirá de baliza para a pesquisa. Existem interpretações do Segundo Reinado feitas a partir de duas matrizes distintas: uma republicana; outra, de tendência monarquista. O imperador, em meio a opiniões diversas, é disputado por perspectivas conflitantes, contrapostas em princípios e objetivos. Luís Martins (1910-1981), no seu livro O patriarca e o bacharel, cuja versão inicial é de 1932 e a definitiva, de 1953, enfileirando um cortejo de adjetivos, demonstra bem essa duplicidade:

É como se houvéssemos tido dois Pedro II. Um, o Pedro II dos depoimentos monarquistas, era bom, liberal, erudito, inteligente, grave,

\footnotetext{
${ }^{31}$ Max Fleiuss. "Alocução". In: Dom Pedro Segundo. Rio de Janeiro: Imprensa Nacional, 1940, p. 185 e p. 194.

${ }^{32}$ Max Fleiuss. "Alocução". Op. cit., p. 188.
} 
honesto, tolerante e sábio. O outro, o Pedro dos republicanos históricos, teria sido mau, mesquinho, medíocre, invejoso, pérfido, grotesco, tirânico e ao mesmo tempo "banana", sem noção exata da dignidade imperial, que the competia. ${ }^{33}$

Novamente, efetiva constante, surge o dilema do duplo. Esse parece ser o maior desafio de todos os intérpretes do monarca: quando o personagem parece ter sido dois, é preciso unificá-lo em um; quando surge uno, é preciso identificar as tramas do arranjo que o forma. Entre o pássaro e a sombra, a memória e a história, há uma distância que, incontornável, necessita ser percorrida e destrinchada. A partir dessa inferência inicial que pode ser sintetizada da seguinte maneira: as interpretações, feitas a partir de matizes políticas rivais, variam de acordo com o posicionamento de quem escreve em relação à República -, ficou evidente um fator: a necessidade básica, a fim de evitar entendimentos personalistas ou caricaturais, de identificar a maneira como se arranjam adaptando, aqui, a ideia de Kantorowicz - os dois corpos de d. Pedro II. É isso o que permite, de início, não tomar uma coisa pela outra (foi mau imperador por ter sido diletante e desinteressado; foi exemplo de governante por ter sido homem sábio e bom pai de família. Daí por diante, de acordo com as intenções de quem ajusta os fatores, é possível fazer as mais diversas combinações). Assim, de maneira sutil, é possível entender que um aspecto está sempre ligado ao outro; compreender como uma perspectiva neutraliza e justifica a outra, tornando o conjunto politicamente produtivo (por ser um homem ligado ao saber é que se legitimou enquanto governante; não se tornou cidadão por desagradar-lhe o fato de ser rei, mas sim para o ser).

Por conta dessa necessidade de bem elucidar os arranjos, chama atenção a postura adotada por José Murilo de Carvalho ao biografar, há poucos anos, o imperador - notese como, novamente, é preciso retornar ao tempo presente a fim de formular problemas, consolidar um recorte e selecionar as fontes. O historiador divide o monarca em dois, fia-se nessa cisão e vai tecendo, com elaborada narrativa, linguagem fluida, capítulos curtos, estilo leve e bem humorado, a vida do imperador. Salta aos olhos, conforme avança a leitura, que a combinação entre uma obra de divulgação - o que é fundamental para expandir a reflexão histórica - com as ideias defendidas no texto, torna-se complexa. Em forma e conteúdo, vem à tona, por meio das escolhas do autor, uma

\footnotetext{
${ }^{33}$ Luís Martins. O patriarca e o bacharel. São Paulo: Alameda, 2008, p. 63.
} 
figura positivada. ${ }^{34}$ Desde o começo, assim como uma advertência ao leitor, está explícito que se trata, na verdade, de dois biografados: d. Pedro II e Pedro d'Alcântara. Por trás da pompa das cerimônias e das obrigações de governante, das festas e das falas do trono - com tudo isso se ocupava o imperador d. Pedro II -, havia "um ser humano marcado por tragédias domésticas, cheio de contradições e paixões, amante das ciências e das letras, apaixonado pela condessa de Barral" - era este o Pedro d'Alcântara. ${ }^{35} \mathrm{O}$ imperador e o cidadão, a coroa e a cartola, a murça de penas de galo da serra e a casaca cinzenta, o governante todo poderoso da nação e o viajador pedante do mundo. Todo esse dilema expresso no subtítulo da obra: ser ou não ser. Segundo José Murilo, havia um único elemento de fusão, fator que ligava esses dois Pedros em um só: a paixão pelo Brasil, país ao qual se sacrificou e governou "com os valores de um republicano, a minúcia de um burocrata e com a paixão de um patriota”. Fruto dessa dedicação, ao fim de seu governo, quando foi deposto e exilado, deixou "consolidada a unidade do país, abolidos o tráfico e a escravidão, e estabelecidas as bases do sistema representativo graças à ininterrupta realização de eleições e à grande liberdade de imprensa". Ainda segundo José Murilo, "pela longevidade do governo e pelas transformações efetuadas em seu transcurso, nenhum outro chefe de Estado marcou mais profundamente a história do país". Apesar de tudo, trata-se de um injustiçado: "respeitado por quase todos, não foi amado por quase ninguém". ${ }^{36}$

O autor, em sua interpretação, entende o monarca como um idealista frustrado, a quem desgostava as disputas político-partidárias e os interesses mundanos do poder.

\footnotetext{
${ }^{34}$ A relação primordial entre forma e conteúdo, estilo e interpretação, não pode ser negligenciada em textos historiográficos. Sobre isso, os comentários de Peter Gay são esclarecedores: "O estilo é um centauro, reunindo o que a natureza como que decretou que se mantivesse apartado. É forma e é conteúdo, entrelaçados para formar a tessitura de toda a arte e todo ofício - e também a história. Salvo por alguns artifícios mecânicos de retórica, a maneira se encontra indissoluvelmente ligada à matéria; o estilo molda e é por sua vez moldado pelo conteúdo". Mais adiante, completa: "deve o historiador lembrar que a própria ideia de estilo vem afetada por uma ambiguidade central: há que dar informação e prazer. Abre janelas para a verdade e a beleza - um duplo panorama atordoante". Peter Gay. O estilo na história. Op. cit., p. 11 e p. 20.

35 José Murilo de Carvalho. D. Pedro II: ser ou não ser. São Paulo: Companhia das Letras, 2007, p. 10. Mais adiante, o autor acentua esse conflito entre d. Pedro II e Pedro d'Alcântara: "Este tinha paixão pelos livros, leituras, conversas com sábios, considerava o ofício de imperador um destino ingrato, uma pesada cruz, e os rituais do poder uma grande maçada. Era o Pedro que emergia com força assim que o monarca transpunha as fronteiras do país, transmutado num viajante comum. O outro, d. Pedro II, dizia que, uma vez que o destino lhe reservara o papel de imperador, ele o cumpriria rigorosamente, de acordo com a Constituição e com as leis do país. Era a identidade que predominava dentro do Brasil, onde era visto como um governante cioso de suas obrigações e de sua autoridade, ao ponto de concentrar excessivamente o poder e ofuscar todos ao redor. A imagem de imperador era reforçada pelo recurso a meios de exaltação de sua figura pública, como rituais, cerimônias, retratos, fotos, quadros, bustos”, pp. 80-81.

${ }^{36}$ José Murilo de Carvalho. D. Pedro II: ser ou não ser. Op. cit, pp. 9-10.
} 
Tanto assim que o imperador teria sido incapaz de entender os motivos que levaram ao Quinze de novembro; para Pedro II, estariam todos malucos, pois "só podia ser maluco quem não reconhecesse que ele passara 49 anos trabalhando intensamente pelo progresso do país" ${ }^{37}$ Repercutem, dessa forma, os ecos de um Oliveira Lima, que entendia o imperador como individualidade necessária, "figura que ressalta a todos os olhos", "um relevo tão palpitante", o único a encher a tela do Império. ${ }^{38}$ Surge, neste ponto, uma questão fundamental: os elogios ao monarca evidenciam sua unicidade, seu destaque, sua busca pelo progresso, a longevidade de seu mandato; dessa forma, mais do que pensar em um imperador dividido entre ser ou não ser, talvez seja o caso de entender o seu dilema de outra forma: ser e não ser, um arranjo entre fatores assimétricos, estratégia de diferenciação e legitimidade. O poder sagrado do monarca casava-se com a modernidade de homem do mundo e com suas obrigações dinásticas, não resultando isso em uma síntese excludente ou em crise pessoal, mas na emergência de um lugar privilegiado de governo.

A leitura do livro de José Murilo de Carvalho, a partir da qual foram levantados problemas, exigiu a busca de novas referências e textos diversos; a expansão, em suma, do repertório. Noutra biografia, essa escrita pelo brasilianista Roderick J. Barman, a divisão do imperador, de certa forma, já vem contida no próprio título: Imperador cidadão. Mais do que isso, grande parte da interpretação de Barman se baseia - um caminho que parece obrigatório quando se trata de d. Pedro II, rei apaixonado pela modernidade, progressista avesso a mudanças abruptas - em outra divisão inerente ao próprio poder monárquico: um rei deve ser símbolo de ordem política e social e, além disso, a personificação da identidade nacional - deve, através da transcendência, tornar uno o múltiplo. A partir de símbolos e rituais, que o colocavam acima dos meros mortais, o monarca expõe sua aura misteriosa e realiza sua dupla função. O rei, assim, é um símbolo nacional e uma sentinela vigilante da vida política. O historiador britânico elabora narrativa de fôlego e encontra meios, às vezes arriscados, para entender e

\footnotetext{
37 José Murilo de Carvalho. D. Pedro II: ser ou não ser. Op. cit, pp. 82-83. Vale lembrar, aqui, das sempre interessantes palavras de Gilberto Freyre; segundo este autor, o Quinze de novembro não representou, em essência, um movimento contra o imperador. De acordo com o sociólogo, não havia, no Brasil, nenhuma grande animosidade contra o monarca; a tônica do novo regime foi a conservação da estrutura social nacional: "o descontentamento era difusamente social, e não especificamente político, muito menos contra o imperador ou o Império em particular. [...] Tratava-se, por conseguinte, de uma revolução paradoxalmente conservadora". Gilberto Freyre. Ordem e progresso. São Paulo: Global, 2004, p. 229.

${ }^{38}$ Oliveira Lima. Formação histórica da nacionalidade brasileira. Op. cit, p. 217.
} 
explicar essa cisão - a sua ideia central, no entanto, é bastante clara: "se o imperador chegou a se esforçar para ser um cidadão, o cidadão nunca deixou de ser um imperador". 39

É interessante perceber como Barman, levando em conta os diferentes momentos vividos por d. Pedro enquanto governante - algo bastante razoável quando se pensa em alguém que foi imperador dos 14 aos 63 anos -, ressalta a capacidade política do imperador, mostrando a maneira como ele soube criar um padrão de cidadania, interferir na vida política nacional e manter o Brasil conectado à política internacional. Sobre esse último aspecto, o exemplo mais bem acabado é o da escravidão; após a emancipação dos escravos nos Estados Unidos da América, em 1863, e a derrota dos confederados na guerra civil, tornara-se assunto primordial para o imperador discutir a mudança de regime de trabalho no Brasil - diante do contexto econômico mundial e da opinião internacional, era inaceitável restar o Brasil como único Estado soberano escravista das Américas. As posições políticas de d. Pedro II, portanto, longe de meramente serem - o que não quer dizer que não fossem - os tão propalados símbolos de humanismo e ilustração, são características de um político sagaz e conectado ao contexto externo Barman credita, por exemplo, a nomeação, mesmo após quatro ministérios liberais sucessivos, do gabinete de Francisco de Paula Sousa e Melo, "o mais antigo e prestigioso dos líderes liberais" à época, ao contexto europeu de 1848, uma tentativa de articular o cenário externo ao interno, mesmo que isso criasse problemas e instigasse a insatisfação dos conservadores.

Chama atenção a forma como Barman lança um olhar minucioso sobre o monarca, tomando-o, em todos os seus aspectos, como um elemento fundamental para entender a vida política brasileira e a formação do Estado nacional - o título completo do livro, não nos esqueçamos, é bastante claro: Imperador cidadão e a construção do Brasil (no original, isso fica ainda mais evidente: Citizen Emperor: Pedro II and the Making of Brasil). Para o autor, o legado de d. Pedro II teria sido amplo; as suas principais realizações - "a promoção de uma cultura e de um ideal de cidadania" sobreviveram à mudança de regime em 1889, e foram diretrizes importantes da política brasileira no século XX. Dessa maneira, não só a Primeira República (1889-1930), como a Era Vargas (1930-1945) e os governos liberais seguintes, mas até mesmo “o Regime Militar (1964-1985) foi profundamente influenciado pela visão estabelecida por

\footnotetext{
${ }^{39}$ Roderick J. Barman. Imperador cidadão e a construção do Brasil. Op. cit, p. 9.
} 
D. Pedro II. Somente na década de 1980 essa visão começaria a ser superada" ${ }^{40}$ Sintomaticamente, o autor não comenta o quão excludente esses padrões de cultura e cidadania podiam ser; a ponto de que somente nos anos 1980, com o fim da ditadura militar e a promulgação da Constituição de 1988, as coisas começariam a mudar, ao menos em termos legais, de forma significativa.

Outro aspecto merece destaque. Em alguns casos, esses os mais controversos, Barman elabora explicações psicológicas e clínicas, ligadas à formação pessoal, família, saúde e educação de Pedro d'Alcântara, o que leva a interpretação para campos incertos e pessoais. Nesse sentido, por ter sido, desde muito jovem, figura de poder, centro das atenções - habitava "torre envidraçada", seu ciclo de vida ocorria "em público, sob escrutínio do mundo", havia "disparidade entre crescimento intelectual e emocional" - e foco de disputas políticas durante a adolescência - os embates todos da regência, a exposição de sua imagem pelo gabinete do Regresso e a antecipação da maioridade -, o que se potencializou ainda mais por ser órfão de pais, o imperador criou um complexo de poder e autoridade que lhe impedia aceitar frustrações e contradições, assim como o abandono. A explicação tem, inegavelmente, valor e sentido, mas pode gerar controvérsias quando usada como base de uma interpretação historiográfica. Barman, apesar do rigor com que perscruta Pedro II, em alguns momentos acaba se imiscuindo, mergulhando na intimidade e nos dilemas pessoais do biografado. Isso, porém, não interfere na qualidade de sua análise; além do mais, o autor confessa que, a princípio, não pretendia escrever uma biografia do imperador; seu foco, portanto, nunca recaiu no estritamente pessoal. Após anos de estudos sobre a sociedade brasileira do século XIX, contudo, foi levado, “de modo relutante porém inexorável, de volta a D. Pedro II como a chave para compreender o desenvolvimento do Brasil como Estado-nação". ${ }^{4}$

\footnotetext{
${ }^{40}$ Roderick J. Barman. Imperador cidadão e a construção do Brasil. Op. cit, p. 10.

${ }^{41}$ Roderick J. Barman. Imperador cidadão e a construção do Brasil Op. cit, p. 10 e p. 24. Talvez seja o caso de comentar o fato de que a biografia feita por Roderick J. Barman se insere, com as devidas diferenças, em uma linhagem interessante. É grande o número de estudos sobre d. Pedro II realizados por estrangeiros. O monarca, sempre preocupado em fazer boa figura fora do Brasil, parece ter conseguido realizar seus intentos a proveito. Paralelo a isso (ou incentivado por isso), há o fenômeno da monarquia brasileira, algo que, de forma talvez equivocada, guarda certo exotismo. Eric J. Hobsbawm dá monta disso ao lembrar que, no final do século XIX, "fora da Europa, os dirigentes da China, Japão, Pérsia e talvez com maior cortesia diplomática internacional - Etiópia e Marrocos eram normalmente autorizados a usar esse título [imperador], ao passo que, até 1889, sobreviveu um imperador americano, o do Brasil". In: A era dos impérios (1875-1914). Tradução de Sieni Maria Campos e Yolanda Steidel de Toledo. São Paulo: Paz \& Terra, 2007, p. 88. Tratava-se, sem dúvida, de algo diferente. O francês Jean Soublin, autor de romance sobre o imperador, captou muito bem esse ponto nas "memórias imaginárias": "Se os franceses compreendem facilmente que uma velha inglesa torne-se imperatriz das Índias, relutam em admitir que um curista [o personagem fala do exílio, mais precisamente da estância termal de Vichy] de
} 
Nessa linha de pensamento - e tratando-se de gênero que fora recorrente entre os anos 1920 e 40 -, vale levantar indagações acerca do próprio gênero textual biografia, principalmente quando feito no escopo de um estudo historiográfico. Qual a motivação de um trabalho desse tipo? Até que ponto é interessante ao pesquisador entrar em aspectos íntimos do biografado? A partir de que momento os temas privados passam a ser abordados de forma especulativa ou incoerente, sobrepondo-se aos assuntos públicos? No caso da vida de um monarca, então, na qual os aspectos públicos e privados não têm fronteiras bem definidas (a tal "torre envidraçada" de que fala Barman), a situação é ainda mais complexa. Como impedir a análise de resvalar no sentimentalismo, a subjetividade de recair no subjetivismo?

Em tempos de crise, quando as grandes narrativas e interpretações históricas são postas em questão, quando a informação se apresenta pelo fragmento e pelo detalhe, o biográfico, o apelo ao personalismo, a memorialística e o anedótico, todos são caminhos que se oferecem insinuantes e confortáveis. As abordagens focadas em aspectos residuais vão dar, algumas vezes, em textos capazes, a partir da lógica do entretenimento, de criar um mínimo de referências comuns. Esse quase consumo do passado, podemos entendê-lo como uma obsessão passadista, uma distorção que se faz ao amplificar tudo que é peculiar e dar destaque desproporcional às singularidades. ${ }^{42}$ Esse passadismo, entretanto, não se sustenta sozinho, porque está arvorado sobre um presentismo; ou seja, a obsessão pelo passado se faz a partir de dúvidas atuais, que atingem a subjetividade e os interesses contemporâneos. A transição entre passado e presente - fundamental para, de acordo com Robert Darnton, abrir novas perspectivas e problemas -, se feita sem problematizações e de forma acrítica, conduz a entendimentos equívocos e utilitários. Nos momentos de mudanças - como as que ocorreram no Brasil com a proclamação da República, nos anos 1930 ou na última década, a primeira do século XXI -, mais do que perspectivas de futuro, é o passado que vem à tona. Assim, o segundo imperador - da mesma forma que muitas personalidades do passado - emerge enquanto emblema, como referência e parâmetro.

barba branca, amável e meigo, possa reinar num país que imaginam povoado de índios nus". Jean Soublin. D. Pedro II - o defensor perpétuo do Brasil. Memórias imaginárias do último imperador. Tradução: Rosa Freira d'Aguiar. São Paulo: Paz \& Terra, 1996, p. 10.

${ }^{42}$ Robert Darnton. Os dentes falsos de George Washington: um guia não convencional para o século XVIII. Tradução de José Geraldo Couto. São Paulo: Companhia das Letras, 2005, p. 11. 
Na historiografia contemporânea, essa busca de significados presentes no passado é símbolo de desconforto com a própria contemporaneidade, de medo do futuro, temor da perda e do esquecimento. Segundo Pierre Nora, num famoso texto escrito em 1984:

Como não ver, nesse gosto pelo cotidiano passado, o único meio de nos restituir a lentidão dos dias e o sabor das coisas? E nessas biografias de anônimos, o meio de nos fazer compreender que não é pelas massas que se consagram as massas? Como não ler, nessas bolhas de passado que nos remetem tantos estudos de micro-história, a vontade de igualar a história que nós reconstituímos com a história que nós vivemos? Memória-espelho, dirse-ia, se os espelhos não refletissem a imagem do mesmo, quando, ao contrário, é a diferença que nela procuramos descobrir; e no espetáculo desta diferença, o brilho súbito de uma inencontrável identidade. Não mais uma gênese, mas o decifrar do que nós somos à luz do que nós não somos mais. ${ }^{43}$

Ou, conforme afirma o historiador italiano Paolo Rossi,

entre as razões que explicam as paixões atuais pelo tema da memória há, sem dúvida, uma grande "demanda de passado" e uma renovação do interesse pelos argumentos e temas que pareciam superados ou marginais, tanto para os teóricos da invasão geral da técnica no mundo moderno, quanto para os teóricos da superação do capitalismo e da revolução mundial: o localismo, o nacional, o regional, o urbano, o bairro, as minorias, os grupos, suas culturas etc. ${ }^{44}$

Curiosamente, assim como esse interesse pelos temas locais e específicos, a retomada dos discursos histórico-personalistas, mesmo não tratando de anônimos, e sim de celebridades cheias de subjetividade - o que, talvez, iguale um pouco as coisas; afinal, um anônimo tornado conhecido pode equivaler a uma figura pública cuja vida íntima é trazida à luz -, segue essa mesma linha de "demanda de passado" e apelo memorialístico. São os dois lados de uma mesma moeda. Da mesma forma que se rastreia uma identidade nos grupos e temas que antes estavam excluídos da História, criam-se superpessoas na interpretação do passado e nos espaços públicos, tornando,

\footnotetext{
43 «Comment ne pas voir, dans ce goût du quotidien au passe, le seul moyen de nous restituer la lenteur des jours et la saveur des choses? Et dans ces biographies d'anonymes, le moyen de nous faire saisir que ce n'est pas par masses que se livrent les masses? Comment ne pas lire, dans ces bulles de passe que nous livrent tant d'études de micro-histoire, la volonté d'égaler l'histoire que nous reconstruisons à l'histoire que nous vivons? Mémoire-miroir, dirait-on, si les miroirs ne réfletaient l'image du même, quand, au contraire, c'est la différence que nous cherchons à y découvrir; et dans le spectacle de cette différence, l'éclat soudain d'une introuvable identité. Non plus une genèse, mais le déchiffrement de ce que nous sommes à la lumière de ce que nous ne sommes plus ». Pierre Nora. "Entre mémoire et Histoire: la problématique des lieux". In: NORA, Pierre (org). Les lieux de mémoire. Op. cit., p. XXXIII.

${ }^{44}$ Paolo Rossi. O passado, a memória e o esquecimento: seis ensaios da história das ideias. Tradução de Nilson Moulin. São Paulo: Editora UNESP, 2010, p. 25.
} 
através da referência e exaltação do outro modelar, palatável a complexa e necessária relação entre memória, individual e/ou coletiva, e a história. ${ }^{45}$

As representações de d. Pedro II, ao tratarem de um controverso arranjo de duplos, transformaram o imperador numa efetiva "superpessoa" da história nacional. Para o bem ou para o mal - o que revela a produtividade e o risco desse arranjo -, $\mathrm{d}$. Pedro sempre está em pauta, é uma pessoa-instituição; os mesmos temas, tal como a sua famosa e elevada cultura, são usados para criticá-lo ou para elogiá-lo. O monarca é, em suma, um memorável "patrimônio brasileiro" - Lilia Schwarcz, inclusive, parafraseia Roberto Da Matta e diz que “d. Pedro II não nasceu, foi fundado; tornou-se patrimônio nacional". ${ }^{46}$ Nesse mesmo sentido, talvez se possa acrescentar um novo fator ao porquê de o recorte temporal da pesquisa terminar nos anos Vargas: a hipótese é de que, com esse governante, surgia um novo paradigma de "superpessoa" na história brasileira, um diverso e poderoso marco memorativo, tão forte e abrangente que rivalizava com o monarca. ${ }^{47}$ São personalidades reconhecíveis, cruzamentos de crenças e esperanças, patrimônios nacionais que viveram momentos de glórias, crise e a consagração póstuma. Há, talvez, uma diferença fundamental e significativa entre eles, algo que agrega sentido ao recorte: se Pedro II foi fundado, Vargas fez-se fundar. Em outras palavras, trata-se da diferença entre a prática de uma política implícita para uma explícita. Explica-se, assim, o porquê de o monarca, no campo da representação memorialística e da celebração pessoal, transitar com maior facilidade entre classes

\footnotetext{
${ }^{45}$ Ressalte-se que a noção de superpessoa foi inspirada nas ideias de Roberto DaMatta; segundo esse autor: "Num sistema de pessoas, todos se conhecem, todos são 'gente', todos se respeitam e nunca ultrapassam seus limites. [...] É nesse universo de pessoas que encontramos os medalhões, os figurões, os ideólogos, as pessoas-instituições (com o perdão da redundância): aqueles que não nasceram, foram fundados. É ainda aqui que encontramos os líderes, eles mesmos encarnando - como já havia observado Lévi-Strauss - as correntes sociais que defendem e desejam implementar. De fato, a superpessoa no Brasil tende a entrar num plano que chamei Nirvana social, uma área onde ela fica acima e além das acusações, passando a ser o que gostamos de chamar de 'nosso patrimônio' ou, melhor ainda, 'patrimônio brasileiro nacional'”. Roberto DaMatta. Carnavais, malandros e heróis: para uma sociologia do dilema brasileiro. Rio de Janeiro: Rocc, 1997, pp. 232 e 233.

${ }^{46}$ Lilia M. Schwarcz. As barbas do imperador. Op. cit, p. 45.

${ }^{47}$ Interessante notar como d. Pedro II parece ter sido, efetivamente, um paradigma. Francisco Doratioto comenta a respeito disso; para ele, entretanto, a primeira personalidade pública que conseguiu ir além do paradigma não foi Vargas, e sim o Barão de Rio Branco (1845-1912). Este, porém, não rompeu o paradigma, pois, exímio diplomata que era, conseguiu ficar suspenso entre a Monarquia e a República: "O resultado da arbitragem sobre Palmas, que garantiu ao país a posse de 30.621 quilômetros quadrados, tornou o barão de Rio Branco popular no Brasil e impulsionou sua carreira. Essa vitória também o qualificou para ocupar a posição de figura patriótica paradigmática no imaginário brasileiro, que antes fora de Pedro II. Ademais, ele tinha entre seus melhores amigos expoentes monarquistas que o viam como um deles, e, graças a seu instinto de sobrevivência, Rio Branco também não se indispôs com os republicanos, tanto que ocupava cobiçada função pública em Paris". Francisco Doratioto. "O Brasil no mundo: idealismos, novos paradigmas e voluntarismo". In: Lilia M. Schwarcz (coord.) A abertura para o mundo (1889-1930). Rio de Janeiro: Objetiva, 2012, p. 140.
} 
diferentes, grupos culturais distintos e adversários políticos. Com Getúlio Vargas, a relação é um pouco diferente, mais tensa. ${ }^{48}$

Retomando algumas ideias, após esse breve parêntese, é possível dizer que as superpessoas da memória operam, com bom aproveitamento, como conectores entre o passadismo e o presentismo. Pode-se pensar, ainda, que, compondo o pano de fundo da voga biográfica e da presença memorial de superpessoas, desse "interesse quase espasmódico pela memória e pelo olvido", está “o terror que temos da amnésia”, as "dificuldades renovadas que se interpõem em nossas tentativas de conectar num conjunto, aceitável de algum modo, o passado, o presente e o futuro". ${ }^{49}$ Daí, das desilusões com o presente e das aflições com o porvir, é que emerge o interesse por um passado suave e curioso, assim como apego à memória da superpessoa, ao modelo humano de conduta, ao exemplo que não se quer perder e que se deseja ver no futuro. ${ }^{50}$ Precisa-se do texto que negue a perda do exemplo e que, também, sustente o reconhecimento com o leitor, resgate a personalidade humana em todos os seus detalhes polêmicos, sensuais, anedóticos - segue-se, assim, a lógica da informação, daquilo que, segundo Walter Benjamin, aspira à verificação imediata, compreensível em si e para si, mas que, na medida em que se difunde, declina com o entendimento da experiência. ${ }^{51}$

\footnotetext{
${ }^{48}$ Sobre isso, vem ao caso uma passagem emblemática. Quando solicitado por Gilberto Freyre, em 1940, a responder um dos inquéritos que serviriam de base para a elaboração do monumental Ordem e progresso, Getulio Vargas “observou maliciosamente, depois de o ler [ler o questionário], a princípio com um meio-sorriso, de certa altura em diante, sério e concentrado: 'Este inquérito descobre qualquer um. E eu não sou homem que se descubra, mas que deve ser descoberto"”. In: Gilberto Freyre. Ordem e progresso. $O$ p. cit, p. 60 . As dezessete perguntas do questionário, que abordam temas diversos, desde assuntos biográficos/pessoais até políticos/culturais, estão reproduzidas na página 65 da edição consultada de Ordem e progresso.

${ }^{49}$ Paolo Rossi. O passado, a memória e o esquecimento. Op. cit, p. 30.

${ }^{50}$ As palavras de Beatriz Sarlo, sobre esse assunto, são bastante reveladoras: "As últimas décadas deram a impressão de que o império do passado se enfraquecia diante do 'instante' (os lugares-comuns sobre a pós-modernidade, com suas operações de 'apagamento', repicam o luto ou celebram a dissolução do passado); no entanto, também foram as décadas de museificação, da heritage, do passado-espetáculo, das aldeias Potemkin e dos theme-parks históricos; daquilo que Ralph Samuel chamou de 'mania preservacionista'; do surpreendente renascer do romance histórico, dos Best-sellers e filmes que visitam desde Tróia até o século XIX, das histórias da vida privada, por vezes indiferenciáveis do costumbrismo, da reciclagem de estilos, tudo isso que Nietzsche chamou, irritado, de história dos antiquários. 'As sociedades ocidentais estão vivendo uma era de auto-arqueologização', escreveu Charles Maier. Esse neo-historicismo deixa os historiadores e ideólogos inconformados, assim como a história natural vitoriana deixava inconformados evolucionistas darwinistas. Indica, porém, que as operações com a história entraram no mercado simbólico do capitalismo tardio com tanta eficiência como quando foram objeto privilegiado das instituições escolares desde o fim do século XIX ". Beatriz Sarlo. Tempo passado: cultura da memória e guinada subjetiva. Tradução de Rosa Freire d'Aguiar. São Paulo: Companhia das Letras; Belo Horizonte: UFMG, 2007, p. 11.

${ }^{51}$ Walter Benjamin. "O narrador: considerações sobre a obra de Nikolai Leskov". In: Magia e técnica, arte e política: ensaios sobre literatura e história da cultura. Tradução de Sérgio Paulo Rouanet. Prefácio
} 
Há a necessidade da conduta, do grande homem, da figura que mostra como poderíamos ser melhores; no entanto, como se trata de um ser pontuado por dilemas existenciais e pequenas tragédias domésticas, é alguém que nos alivia das frustrações cotidianas, porque se parece tanto conosco, é tão familiar e também sofre os desgostos do dia-a-dia. Uma personalidade, portanto, que conecta tempos históricos, possibilita comparações e cria laços de identidade. Trata-se, assim, de um passado que, tramado a partir de diversos interesses e atento às expectativas, adentra o presente e se afirma pela negação; nessa lógica, como comenta o historiador Julio Pimentel Pinto, "visita-se o passado para neutralizar o presente enquanto lugar de mudança e reafirmar a tradição, não a que engendra o presente não aceito, mas a que pode significar seu banimento". ${ }^{2}$

Dessa maneira, ao invés da crítica e da problematização, teme-se o escoamento do tempo; busca-se o passado com ansiedade e sede de informação, como quem vai a uma feira de curiosidades ou, mesmo, como quem vai às compras. A personalidade mais inusitada, a que se destaca em meio às outras, desponta como extravagante, é a mercadoria mais atrativa e valiosa - e d. Pedro II, esse duplo repleto de ambiguidades, cumpre bem o papel. Surge, assim, uma historiografia que se desequilibra em sua relação com a memória, que atende às crenças de um público desejoso de passado; o que, não se pode negar, "não a torna pura e simplesmente falsa, mas ligada ao imaginário social contemporâneo, cujas pressões ela recebe e aceita mais como vantagem do que como limite". ${ }^{53}$ Esse tipo de historiografia não oferece hipóteses ou indagações, mas certezas e segurança; no mesmo pacote, o excesso, o notável, o insólito, o distante, se convertem em próximos e palatáveis, a alteridade se familiariza em igual. Segundo afirma Beatriz Sarlo, "esses modos de história respondem à insegurança perturbadora causada pelo passado na ausência de um princípio explicativo forte e com capacidade inclusiva"; e o incômodo causado por essa ausência fecha o ciclo mercadológico, pois, “como a dimensão simbólica das sociedades em que vivemos está organizada pelo mercado, os critérios são o êxito e o alinhamento com o senso comum dos consumidores". 54

\footnotetext{
de Jeanne Marie Gagnebin. São Paulo: Brasiliense, 1994, p. 203. O texto em questão foi escrito no ano de 1936, num contexto complexo e trágico, mas que, de certa forma, mantém boa parte de sua atualidade.

52 Julio Pimentel Pinto. Uma memória do mundo: ficção, memória e história em Jorge Luis Borges. São Paulo: Estação Liberdade: Fapesp, 1998, p. 144.

${ }^{53}$ Beatriz Sarlo. Tempo presente. Op. cit., p. 13.

${ }^{54}$ Beatriz Sarlo. Tempo presente. Op. cit., p. 15.
} 
No entanto, seria incongruente, quase uma cegueira purista, querer tomar a escrita da história como uma tarefa que consegue se alhear plenamente dos interesses que a circundam. Peter Gay, em um texto elegante e original, revela muitas das duplicidades e polaridades do ofício do historiador; faz mais do que isso, mostra como, ao invés de completamente negativas, tal como poderiam parecer em um primeiro momento, essas duplicidades - "a natureza dual da história" - são constituintes do próprio ofício e podem, quando bem problematizadas, se tornar produtivas. O autor, ao focar o tema do estilo - algo que, ao mesmo tempo em que é próprio do indivíduo, não deixa de ser pensado e aprimorado ao longo da prática; como ele mesmo diz, "o estilo é o homem, durante boa parte do tempo" - acerta em cheio um dilema crucial: seria equivocado fazer uma distinção absoluta entre subjetividade e objetividade, da mesma forma que seria leviano ver nisso uma simples relação de interesses no fazer historiográfico. $\mathrm{O}$ ofício do historiador, como afirma, "é permeado pelo paradoxo". Paixão e consciência, literatura e ciência, estilo e objetividade, pressão social e interesse pessoal, profissionalização e amadorismo, todos são fatores incontornáveis que, de certa forma, permitem ao historiador encontrar meios de formular novas indagações e se lançar em perspectivas inexploradas. Isso fica bem expresso naquilo que diz a respeito da memória:

\begin{abstract}
dizem-nos amiúde, e com razão, que muitos historiadores presidem à construção da memória coletiva. E não são arquitetos que tenham recebido carta branca de seus patronos. Sofrem pressão para projetar uma fachada grandiosa, e até gloriosa, que possa guardar apenas uma ligeira semelhança com a estrutura dos fatos ocultos por trás. A memória, como sabemos, é o dócil ministro do interesse próprio, e a memória coletiva, neste como em outros aspectos, é igual à memória dos indivíduos. Grande parte da memória coletiva é uma distorção conveniente ou uma amnésia de idêntica conveniência; frequente tarefa, até em demasia, do historiador tem sido a de auxiliar sua cultura a lembrar fatos que não ocorreram, a esquecer eventos que existiram. A cultura quer um passado que possa usar. Seria quase dispensável acrescentar que tal prática cosmética raramente é venal ou sequer consciente; parafraseando George Bernard Shaw, não é preciso pagar aos historiadores para fazer o que estão loucos para oferecer de graça ${ }^{55}$.
\end{abstract}

As polaridades da história, porque reveladoras, são fundamentais. Na maneira de aceitá-las, contorná-las, problematizá-las, negá-las, é que está contida boa parte do ofício do historiador. Nelas, apesar de todos os caminhos possíveis, está expresso um aspecto fundamental: a história é escrita nas fronteiras e a partir da alteridade. Quando se trata do tema da memória, isso jamais pode ser obliterado. Lembro, aqui, das

\footnotetext{
${ }^{55}$ Peter Gay. O estilo na história. Op. cit., p. 186.
} 
palavras de Michel de Certeau acerca de todos os fatores epistemológicos e científicos envolvidos no próprio ato de pesquisar e escrever a história. Segundo esse pensador, a pesquisa historiográfica, enquanto articulada “com um lugar de produção socioeconômico, político e cultural”, faz surgir interrogações acerca do real em duas posições bem diferentes daquilo que se possa entender como procedimento científico:

o real enquanto é o conhecimento (aquilo que o historiador estuda, compreende ou "ressuscita" de uma sociedade passada) e o real enquanto implicado pela operação científica (a sociedade presente a qual se refere a problemática do historiador, seus procedimentos, seus modos de compreensão e, finalmente, uma prática de sentido). De um lado o real é o resultado da análise e, do outro, é o seu postulado. Estas duas formas de realidade não podem ser nem eliminadas nem reduzidas uma a outra. A ciência histórica existe, precisamente, na sua relação. Ela tem como objetivo próprio desenvolvê-la em um discurso. Certamente, segundo os períodos ou os grupos, ela se mobiliza, de preferência, em um de seus dois polos. ${ }^{56}$

Dessa forma, por transitar entre temporalidades distintas e interesses objetivos, é inviável pensar a escrita da história sem ambiguidades; afinal, "fundada sobre o corte entre um passado, que é seu objeto, e um presente, que é o lugar de sua prática, a história não para de encontrar o presente no seu objeto, e o passado, nas suas práticas". Entende-se, então, como a história está fundada em territórios duplos, em "fronteiras que articulam uma sociedade com o seu passado" e que, ao mesmo tempo, distingue-os; a atualidade encontra no passado o seu outro, que quer explicar mas do qual precisa para entender a si mesma. ${ }^{57}$ É por ser tecida através de um arranjo e a partir de um lugar, este território de fronteira, e por se realizar somente em relação com o outro, que a escrita da história, no seu trato com a linguagem, não pode ser entendida como mera ficção ou reflexão epistemológica; por isso, também, que as questões dos limites são profícuas em levantar debates, revelar ambiguidades, polaridades e controvérsias, todas, como não poderia deixar de ser, repletas de sentidos e proposições. ${ }^{58}$

O gênero biográfico, portanto, ainda mais quando inserido no escopo do trabalho historiográfico, apesar de fundamental, é repleto de armadilhas e caminhos tortuosos em meio aos quais é preciso buscar alternativas e se orientar. Novamente, é preciso ampliar

\footnotetext{
${ }^{56}$ Michel de Certeau. A escrita da história. Tradução de Maria de Lourdes Menezes. Revisão técnica de Arno Vogel. Rio de Janeiro: Forense Universitária, 2007, p. 45.

${ }^{57}$ Michel de Certeau. A escrita da história. Op. cit., p. 46 e p. 48.

${ }^{58}$ Sobre os temas da fronteira e do lugar, tanto na perspectiva da história quanto da literatura, ver o excelente livro de Julio Pimentel Pinto, Uma memória do mundo: ficção, memória e história em Jorge Luis Borges. Op. cit., obra que inspirou boa parte dessas reflexões.
} 
o repertório, procurar novas questões e referências. Lília Moritz Schwarcz, por exemplo, em outra pesquisa de grande fôlego, perscruta a vida do segundo imperador, mas sem o fazer somente em perspectiva biográfica. $\mathrm{O}$ interessante é notar como $A s$ barbas do imperador se trata, dessa forma, de uma biografia não biográfica; o foco do estudo não é a pessoa do imperador, e sim a sua representação pública, o seu regime, a constituição de uma monarquia de matriz europeia em terras tropicais, em uma antiga colônia - o subtítulo evidencia tal enfoque: D. Pedro II, um monarca nos trópicos. Trata-se, portanto, de um livro sobre a constituição e consolidação - ou a "grande inauguração" - da monarquia brasileira, uma experiência partilhada, através de leituras e interpretações, por diferentes segmentos da população; afinal, "não basta imaginar apenas uma recepção cultural passiva por parte dos grupos populares e nem mesmo um estranhamento absoluto da cultura oficial. A cultura é dinâmica na medida em que está sempre em movimento, alimentada por um jogo contínuo". ${ }^{59}$ Daí porque o livro aborda todo um cabedal simbólico e representativo, a saber, rituais, roupas, residências oficiais, corte, festas, acessórios, pinturas, fotografias. O interesse é perceber como o monarca, segundo a autora, parece aglutinar representações e sentidos distintos em uma só pessoa, é um depositário de crenças e esperanças várias; perceber, da mesma forma, como a monarquia brasileira se estabeleceu sobre a fusão, e fez disso o traço distintivo da nacionalidade, entre elementos rituais de origem medieval e práticas e fatores locais diversos, tais como os símbolos de matriz tropical - os títulos nobiliárquicos referentes à cultura indígena e à natureza, a murça de papo de tucano (ou papo de galos da serra, como Heitor Lyra não abre mão de dizer), ramos de café e tabaco na heráldica, são exemplos, todos, dessa fusão.

Surgem, dessa combinação de fatores distintos, dificuldades próprias desse regime. Primeiro, se assumir diferente em meio a repúblicas. Segundo, a necessidade de partilhar dos ideais de cultura e civilização europeia, mesmo sendo um Estado escravocrata; uma questão que passa longe de ser simples, pois, se é necessário afirmarse externamente, é preciso convencer, também, a população local a participar do regime. São necessárias, assim, referências internas, tais como respeitar os reis africanos e as práticas populares; é preciso, então, negociar para se afirmar. Trata-se de um jogo de trocas simbólicas, sem regras bem definidas e no qual as datas cívicas se confundem com as festividades populares, o ritual regrado da corte liga-se às práticas da rua, $\mathrm{o}$

\footnotetext{
${ }^{59}$ Lilia M. Schwarcz. As barbas do imperador. Op. cit., p. 41 e p. 31.
} 
europeu ao indígena e ao africano. É um caminho de mão dupla, percorrido sempre pela relação entre o comum e o peculiar; trata-se, portanto, de redefinição e recriação de fatores já existentes, formação de uma cultura dinâmica e alimentada constantemente pelo uso de modelos herdados de civilização, mas reinterpretados num contexto tropical e sincrético. Em outras palavras: "aqui tudo se deu ao contrário, primeiro surgiu a forma e depois tratou-se de preenchê-la com conteúdo ao mesmo tempo comum e particular". Mais adiante, complementa a autora: "se o imaginário popular se nutriu da realeza, e de certa forma se 'europeizou', também é possível supor o oposto: a monarquia brasileira se impregnou de elementos da cultura local". ${ }^{60}$

A proposta formulada por Lilia Schwarcz, fomentada sobre o diálogo entre história e antropologia, é aquela que contorna melhor a confusão entre a duplicidade do rei, porque evidencia que tudo o que envolve o monarca é usado para explicar a construção do seu poder e de sua figura pública. A combinação de história e antropologia, a busca pela dimensão social do pensamento e dos símbolos, a extração de significados dos documentos, passando do texto ao contexto e voltando ao primeiro, porém, é uma proposta árdua. ${ }^{61}$ Nesse sentido, é interessante perceber como a leitura em paralelo das obras de Roderick Barman e Lilia Schwarcz revelam traços particulares e intenções distintas. Nisso não há esquecimentos nem falhas, e sim escolhas, especificidades, características que, ao invés de contrapostas, devem ser tomadas, antes, como complementares. Importante notar, nesse sentido, como as áreas do conhecimento estão umbilicalmente ligadas, uma servindo de termômetro à outra; logo, não se trata de insistir sobre a interdisciplinaridade, pois as disciplinas sempre são, inevitavelmente, interdisciplinares - uma não se define, sequer existe sem a outra, mesmo quando se preocupam excessivamente em estabelecer fronteiras entre si. O fundamental é estar aberto ao olhar distinto e tomá-lo como complementar, revelador em sua particularidade; essa, talvez, a maior beleza das ciências humanas: compreender como os diferentes modos de pensar precisam, sempre, reconhecer a diferença, dialogar, alertar e afetar uns aos outros. As características dos textos, assim, ao invés de oposições, revelam, muitas vezes, necessidades de aproximação. ${ }^{62}$

\footnotetext{
${ }^{60}$ Lilia M. Schwarcz. As barbas do imperador. Op. cit., p. 204 e p. 520.

61 Robert Darnton. O grande massacre de gatos e outros episódios da história cultural francesa. Tradução de Sonia Coutinho. Rio de Janeiro: Graal, 1986, p. 17.

${ }^{62}$ É pertinente lembrar, sobre esse assunto, das palavras de Claude Lévi-Strauss que - em um texto cuja publicação francesa data de 1949 -, tratando da relação entre história e etnologia, argumentou que "a diferença fundamental entre elas não é nem de objeto, nem de objetivo, nem de método e que, tendo o
} 
O historiador britânico aborda de forma menos profunda as questões culturais que envolvem o monarca, seu foco é a política; na obra de Lilia Schwarcz, são os temas simbólicos e rituais que predominam. O primeiro, por entender o monarca como peça fundamental da formação do Estado-nação, utiliza-se de ampla documentação diplomática e pessoal, o que o acaba conduzindo ao nível da minúcia, do íntimo, da doença, do trauma. A segunda, a partir de extensa pesquisa, majoritariamente iconográfica e de cultura material, parte do imperador para entender a redefinição cultural que marca a formação da monarquia brasileira. Percebe-se como o movimento das obras é distinto, como trilham caminhos diversos para decifrar o enigma do imperador. Por não focar em análise simbólica, os comentários de Barman sobre a intimidade de d. Pedro parecem estranhos e geram desconfiança. $\mathrm{O}$ oposto vale para a obra de Lilia Schwarcz: as pertinentes interpretações do simbólico e das representações do monarca, em alguns momentos, não realizam aprofundamentos políticos. Note-se, por exemplo, como o livro de Barman faz uma análise detida da infância de d. Pedro, ressaltando os conflitos da regência e da maioridade; Lilia Schwarcz, por sua vez, trabalha muito bem a vida adulta do imperador, quando sua imagem foi difundida e, em muitos momentos, autoelaborada. Enquanto foi centro de intensa disputa política, o imperador é mais bem entendido através de um enfoque; ao se consolidar como político, criador de símbolos e produtor de mitos, por outro. Unidas, essas duas interpretações distintas se aproximam da proposta defendida por Robert Darnton, transitar entre passadismo e presentismo abrindo perspectivas e fugindo de armadilhas. O pai da pátria de Darnton usava uma dentadura - os dentes falsos de George Washington -, e, pior, de madeira; nosso Pedro II, uma barba volumosa, mas que era denunciada enquanto símbolo pela voz fina. ${ }^{63}$ São aspectos que compõem um todo - um mito e uma história -

mesmo objeto, que é a vida social, o mesmo objetivo, que é a melhor compreensão do homem, e um método em que varia apenas a dosagem dos procedimentos de pesquisa, elas se distinguem sobretudo pela escolha de perspectivas complementares. A história organiza seus dados em relação às expressões conscientes, e a etnologia, em relação às condições inconscientes da vida social”. Mais adiante, completa: "No entanto, num caminho em que seguem no mesmo sentido o mesmo percurso, apenas sua orientação é diversa. Os etnólogos caminham para frente, buscando, através de um consciente que nunca deixam de considerar, chegar cada vez mais perto do inconsciente a que se dirigem. Os historiadores, por sua vez, avançam, por assim dizer, em marcha a ré, mantendo o olhar fixo nas atividades concretas e particulares, das quais só se afastam para encará-las sob um ângulo mais rico e mais complexo. Verdadeiro Janus de duas faces, de qualquer modo é a solidariedade entre as disciplinas que permite manter a visão da totalidade do percurso". Claude Lévi-Strauss. "História e etnologia". In: Antropologia estrutural. Op. cit., p. 42 e pp. 51-52.

63 "No final de 1849, o imperador havia deixado a barba cobrir-lhe o rosto, e esse estilo foi mantido pelo restante de sua vida. A barba cheia dava-lhe um ar de dignidade e uma presença que mascaravam sua juventude. D. Pedro II, porém, nada podia fazer para mudar a voz, que um visitante norte-americano ao 
, têm sua importância e devem ser conectados a interpretações amplas; se entendidos enquanto desarticulados, porém, poderiam levar, no limite, a um passadismo ensimesmado. Mais ainda, poderiam conduzir a uma antropologia de "povos sem história", ou a uma história de "povos sem cultura"; não seria preciso dizer, ambas ultrapassadas. $^{64}$

Os textos mais recentes e difundidos são aqueles que forneceram a moldura, a maneira para entender os assuntos abordados. São, em outras palavras, os que dão fundamento ao repertório do historiador. A pesquisa parte do presente e do conhecido para atingir o passado e o desconhecido; do debate atual e mais difundido para a abordagem do debate anterior e de autores menos famosos. Foi, nesse sentido, a leitura dos textos de Nelson Werneck Sodré, Sérgio Buarque de Holanda, Lilia M. Schwarcz, Roderick J. Barman, José Murilo de Carvalho e da revista Veja, com suas especificidades contextuais, teóricas, estilísticas, metodológicas e temáticas, os que permitiram levantar problemas, buscar novos documentos e estabelecer o recorte temporal - este último foi pensado, sobretudo, a partir do livro de Sodré e dos capítulos finais das obras de Schwarcz e Barman, sendo que todos os três textos evidenciam a importância que a memória de d. Pedro II assumiu entre os anos de 1920/40. Da mesma forma, foram as indagações levantadas a partir do tema da biografia que abriram perspectiva para novos entendimentos. Assim, o itinerário da pesquisa segue sempre sentido retrospectivo, jamais evolutivo. O repertório do historiador, fundado sobre o tempo presente, é o que lhe permite buscar um novo e mais amplo conjunto de textos e inquietações. Dessa maneira, levando em conta essa rica bibliografia inicial, acredito que mais do que lançar o homem no seu contexto histórico, conforme a proposta de Nelson Werneck Sodré, é preciso compreender como d. Pedro II foi representado pela historiografia e, principalmente, pela cultura brasileira - mais do que a história do personagem, é preciso, de acordo com Lilia Schwarcz, indagar "acerca da memória produzida sobre d. Pedro II", “ou melhor, a seleção de determinadas memórias

Rio de Janeiro em 1846 caracterizou como 'um tanto feminina'. Um político, ao escrever após a morte do imperador, teve muito menos tato em abordar o assunto: 'instintivamente estremecemos ao ouvir aquela voz fina, aflautada, desarmoniosa, que não parecia sair de corpo tão volumoso e opulento"'. Roderick J. Barman. Imperador cidadão. Op. cit, pp. 166-167.

${ }^{64}$ Marshall Sahlins. Esperando Foucault, ainda. Tradução de Marcela Coelho de Souza e Eduardo Viveiros de Castro. São Paulo: Cosac \& Naify, 2013 (Coleção Portátil, 17), p. 105. 
nacionais" que perpassam suas representações. ${ }^{65} \mathrm{O}$ problema central que move este trabalho, portanto, são as interpretações que foram feitas do imperador, e não propriamente o seu regime. Somente abordando essas representações é possível perscrutar o nevoeiro que paira sobre a sua figura e a torna tão complexa de ser apreendida. Somente assim é possível desconstruir discursos demagógicos, apelos saudosistas e contrassensos memorialísticos. Isso é um problema de primeira monta para o historiador, entender como esse tipo de construção discursiva foi e é empregada na memória e na cultura de um país. Problematizar as representações que foram feitas de d. Pedro II é, talvez, um passo importante para entendermos a forma como a política brasileira se organiza em torno do arranjo produtivo de ambiguidades, da articulação e valorização de um política sem política.

Seguindo essa linha de pensamento, surge, no horizonte, um tema incontornável: as relações entre história e memória.

\footnotetext{
${ }^{65}$ Lilia M. Schwarcz. As barbas do imperador. Op. cit, p. 520 e p. 21 . Nessa linha de pensamento, a autora argumenta: "Artífice e parte, ao mesmo tempo, dos jogos simbólicos que se travavam em torno de sua pessoa (seja pela crítica, seja pela exaltação), o fato é que foi ganhando lugar no imaginário nacional a figura de um rei que, tal qual um fetiche, no limite independia de sua atuação. Sua representação tornouse maior do que a própria pessoa, na medida em que a ‘idealização' se sobrepunha à própria realidade”. Assim, quando se trata do segundo imperador, "talvez a resposta esteja menos na 'história' de d. Pedro na comprovação documental e biográfica - e mais presa à sua memória, e à reelaboração de determinadas imagens em detrimento de outras". A partir dessa constatação, "parte-se da história em direção ao mito, privilegiando a forma como a memória se apropria da história para neutralizá-la, ou torná-la, ela própria, um mito", pp. 519-520.
} 


\section{CAPÍTULO 2}

\section{Apontamentos teóricos: História e Memória}

"O passado é sempre conflituoso. A ele se referem, em concorrência, a memória e a história, porque nem sempre a história consegue acreditar na memória, e a memória desconfia de uma reconstituição que não coloque em seu centro os direitos da lembrança (direito de vida, de justiça, de subjetividade). Pensar que poderia existir um entendimento fácil entre essas perspectivas sobre o passado é um desejo ou um sensocomum".

Beatriz Sarlo, em Tempo passado

As interpretações do longo reinado de d. Pedro II se manifestam enquanto arranjos, tramas que assumem aparência de um todo; a sua história, permeada de detalhes e pequenos dramas, é um cruzamento de variadas intenções e recortes, o que torna difícil, muitas vezes, identificar as vozes que o perpassam e erigem sua memória. Nessa encruzilhada, faz-se necessário traçar alguns apontamentos acerca das relações existentes entre memória e história. Trata-se de um tema complexo, que envolve termos polissêmicos, aponta múltiplas possibilidades e fomenta debates. Memória e história seriam sinônimas? Ou, pelo contrário, maneiras opostas de operar com o passado? Estaria uma tentando superar a outra, revelando, assim, uma intensa disputa pelo passado? Qual é a relação entre o individual e o coletivo nessa suposta disputa? São muitas as questões que podem surgir. Para entrar nessa seara, um bom começo é dar ouvidos a um comentário de aspecto geral:

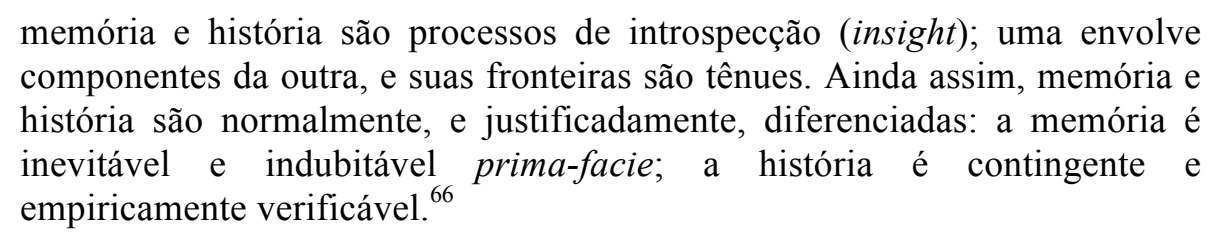

À luz do comentário de David Lowenthal, é possível dizer, em uma abordagem mais objetiva e direta, que a memória, individual ou coletiva, esta ligada umbilicalmente à vida e à percepção pessoal, trata-se de um constituinte fundamental de identidade e de experiência do mundo. A história, mesmo que também seja necessária para configurar identidade, é uma interpretação a ser lançada no mundo público, exposta ao diferente e ao julgamento do "outro", daí porque deve sempre estar pautada em

\footnotetext{
${ }^{66}$ David Lowenthal. "Como conhecemos o passado". In: Revista Projeto História, PUC/SP, no 17, nov. 1998, p. 66.
} 
princípios teóricos e metodológicos consistentes. A consciência que temos do passado, quando baseada na memória, tende para pessoalidade e sensibilidade, sustenta-se pelo vivido e pela experiência. Quando pensamos em narrativas históricas, a base é a interpretação, o recorte do tempo, a perspectiva crítica e a relação de alteridade. ${ }^{67} \mathrm{De}$ acordo com David Lowenthal, a escala de significados comumente ligados à memória transcende e, algumas vezes, obscurece as relações com o passado, pois transforma acontecimentos públicos em experiências, no mais das vezes, pessoais; com a história pode ocorrer o mesmo, mas isso se dá no campo de um discurso compartilhado e entendido a partir de regras comuns; um domínio passível, então, de questionamento e objeções de matriz teórica. Talvez seja possível condensar a questão em uma imagem: enquanto a memória fecha o horizonte na dimensão pessoal ou compartilhada, a história abre a percepção para amplitudes maiores e, na medida em que se possa alcançar, impessoais.

Essa imagem, contudo, apesar de útil e sintética, não é definitiva. É inviável pensar memória e história como elementos completamente estanques, que não se influenciam e que não podem ser, ambos, manipulados e recriados. Da mesma forma, pode ser equívoco entendê-las uma como fenômeno subjetivo; outra, como plenamente objetivo. Ambas tratam da permanência e do esquecimento, assim como se manifestam por meio de narrativas; logo, as duas guardam certo grau de indeterminação temporal, posto que toda narrativa que se refere ao passado é feita a posteriori. No que diz respeito às relações com o passado, portanto, certo grau de anacronismo é inevitável; sem isso, não haveria a mínima possibilidade de dar profundidade humana à vivência presente, assim como seria inconcebível a existência de um pensamento histórico pensamento que deve ser entendido, antes de tudo, enquanto interpretação. Seria impossível, em suma, transformar o passado em narrativa, em linguagem, experiência e conhecimento. Essa necessidade intrínseca de um anacronismo bem medido e pensado, que se constitui na tessitura do próprio narrar, seja para a história, seja para a memória, é um fator fundamental, que dá complexidade à relação existente entre elas. Ter

\footnotetext{
${ }^{67}$ Ulpiano Toledo Bezerra de Meneses, ao tratar do tema dos museus históricos, trabalha com uma chave interpretativa que opõe "teatro da memória" e "laboratório da história"; suas palavras, quando tomadas para pensarmos a relação entre memória e história, são muito elucidativas dos objetivos deste projeto: "Se o Teatro da Memória é um espaço de espetáculo que evoca, celebra e encultura, o Laboratório da História é o espaço de trabalho sobre a memória, em que ela é tratada, não como um objetivo, mas como objeto de conhecimento". Ulpiano Toledo Bezerra de Meneses. "Do teatro da memória ao laboratório da História: a exposição museológica e o conhecimento histórico". In: Anais do Museus Paulista: história e cultura material. São Paulo, v. 2, 1994, p. 41.
} 
consciência disso é o primeiro passo para deslindar as operações com o passado, não ser enredado em seu feitiço e ter consciência do valor das reminiscências e do esquecimento. ${ }^{68}$

Uma questão importante - e incontornável - dos temas da memória e da história, como se vai percebendo, e a fim de não cair em relativismos improdutivos e subjetivistas, é marcar as especificidades de cada uma, mas sem fazer disso limites para as indagações, nem motivo para sugerir verdades pré-estabelecidas. Trata-se de uma relação complexa de proximidade e afastamento, que precisa ser constantemente problematizada. Os comentários de Julio Pimentel Pinto são elucidativos:

História e memória, apesar das aparentes semelhanças, como é insistentemente repetido, diferem. O substrato de ambas talvez seja igual: o passado. É, em primeiro lugar, a ele, passado enquanto temporalidade, que remetem a construção da memória ou a operação histórica. A dissonância entre os dois fazeres, porém, é grande: a memória tecida sobre um determinado evento ou conjunto de eventos dificulta a percepção histórica que se pode ter desses episódios, refaz o itinerário de atribuições de sentidos, constrói um fato oferecendo explicação coerente a episódios, na origem, desconexos. Constrói-se, assim, a memória histórica que, do apelo individual, atinge dimensão coletiva. Memória histórica que (re)cria o passado, operando temporalidade com textualidade, fundindo referencias que estabilizam o presente. ${ }^{69}$

Historia e memória, portanto, inevitavelmente, remetem ao mesmo substrato: o passado. Cada uma possui características específicas, formas diversas de abordá-lo, de elaborar uma teia que aproxime os tempos idos ao vivido no presente. Interessante é pensar uma maneira de, revelando as limitações de ambas, fazer com que uma lance luz sobre a outra. Quando uma cobre seus rastros e esconde seus passos, cabe à outra expô-

\footnotetext{
${ }^{68}$ Sobre a memória enquanto tessitura do narrado e relação com o esquecimento, lembre-se do que disse Walter Benjamin, em ensaio de 1929, a respeito da obra de Marcel Proust: "o importante, para o autor que rememora, não é o que ele viveu, mas o tecido de sua rememoração, o trabalho de Penélope da reminiscência. Ou seria preferível falar do trabalho de Penélope do esquecimento? [...] Não seria esse trabalho de rememoração espontânea, em que a recordação é a trama e o esquecimento a urdidura, o oposto do trabalho de Penélope, mais que sua cópia? Pois aqui é o dia que desfaz o trabalho da noite. Cada manhã, ao acordarmos, em geral fracos e apenas semiconscientes, seguramos em nossas mãos apenas algumas franjas da tapeçaria da existência vivida, tal como o esquecimento a teceu para nós. Cada dia, com suas ações intencionais e, mais ainda, com suas reminiscências intencionais, desfaz os fios, os ornamentos do olvido". Essas colocações completam-se com o que diz Benjamin acerca da tessitura do escrito, pois a forma em que se revela a lembrança, aquilo que emerge do trabalho de Penélope ao inverso, é mais reveladora do que o próprio agente da lembrança: "um acontecimento vivido é finito, ou pelo menos encerrado na esfera do vivido, ao passo que o acontecimento lembrado é sem limites, porque é apenas uma chave para tudo o que veio antes e depois. Num outro sentido, é a reminiscência que prescreve, com rigor, o modo de textura. Ou seja, a unidade do texto está no actus purus da própria recordação, e não na pessoa do autor, e muito menos na ação". Walter Benjamin. "A imagem de Proust". In: Magia e técnica, arte e política. Op. cit., p. 37.

${ }^{69}$ Júlio Pimentel Pinto. Uma memória do mundo. Op. cit., pp. 291-292.
} 
los novamente. Se o apelo individual está na base da memória coletiva, a história deve revelar os interesses envolvidos e subentendidos; se a história carece de pessoas e se torna sufocante para as particularidades, as memórias individuais, dando-lhe substrato humano, podem ser uma alternativa ao pesadume de um passado monolítico. Há, sobre esse assunto, um tema recorrente: a maneira como a memória consegue dar consistência ao passado a partir da experiência e do relato individual. Lembre-se, contudo, que a memória é carregada de significados; que ela pode seguir caminhos distintos e opostos. Pode inundar o passado, se impor e acabar com a diversidade, ou, indo noutra direção, ressaltar o diferente, resistir ao apagamento, corroer o passado oficial. O caso dos regimes autoritários, por exemplo, revela essa dupla face: de um lado, a história estável, supostamente sem rebarbas, a memória oficial que se quer onipresente, a tentativa de justificar a brutalidade, de fundir a história em uma memória única; por outro, a instabilidade, as vítimas e seus relatos, a resistência, a negação do esquecimento, a revelação de outras versões dos fatos, a evidência dos fios soltos. Em meio a essa disputa, a história, em complexo movimento de abertura e fechamento, tem de ser constantemente reescrita.

Pensar os temas da memória e da história exige o retorno aos textos clássicos resgatar, portanto, a memória da própria memória; inserir, ao menos em parte, o tema em uma determinada tradição, a fim de mostrar que, ele mesmo, não pode ser abordado sem a problematização de sua história. Nesse sentido, três obras serão abordadas, aqui, de forma mais detida; isso porque revelam, cada qual com sua especificidade, um viés e uma abordagem do tema - sociológica, historiográfica e filosófica aplicada -, as quais serão importantes para o seguimento da pesquisa. Um dos mais notáveis e pioneiros estudos sobre o assunto é La mémoire collective, obra do sociólogo francês Maurice Halbwachs (1877-1945). O livro, um conjunto de cinco ensaios enfeixados pelo tema da memória e escritos, provavelmente, entre 1925 e 1944, por si só, já é um acontecimento. $^{70}$ Sua primeira publicação se deu postumamente, em 1950 - Halbwachs, tragicamente, morreu em março de 1945, quando estava sendo deportado para Buchenwald, um campo de concentração nazista localizado no leste da Alemanha. Em consequência, o texto ficou incompleto; editores e organizadores, a fim de cumprir

\footnotetext{
${ }^{70}$ Maurice Halbwachs. La mémoire collective. Édition critique établie par Gérard Namer. Paris: Éditions Albin Michel, 1997 (Bibliothèque de L'Évolution de l'Humanité, 28), p. 12 e p. 239.
} 
obrigações profissionais, interferiram diretamente na obra, o manuscrito original passou por modificações, alguns trechos foram omitidos, outros acrescentados. Trata-se de um livro, portanto, cercado de certa mitologia.

No pensamento de Halbwachs, a memória deve estar sempre atrelada diretamente ao tema da consciência, do pertencimento e integração a um coletivo social. O primeiro capítulo do livro, "La mémoire collective chez les musiciens", escrito em 1939, deixa isso claro, pois, a fim de mostrar o aspecto coletivo da questão, vai ao nível da sensibilidade, trata da relação entre a memória e os sons, entre o registro mental e a percepção humana (segundo Gérard Namer, organizador da edição crítica, este texto, anteriormente colocado no fim do livro como anexo, deveria, segundo declaração do próprio Halbwachs, abrir o volume; alteração que, no conjunto da obra, faz todo o sentido). Para o autor, é preciso compreender que a memória musical está baseada em convenções; mesmo que seja possível decorar partituras ou reconhecer os sons apenas ouvindo-os, não se pode escapar do fato de que, antes de tudo, eles não são sonoridades naturais; são, em outra perspectiva, sons criados a partir de símbolos compartilhados. Ou seja, ao tratar da memória musical e das modificações cerebrais emanadas dela, algo que afetaria, num primeiro momento, diretamente a sensibilidade individual, Halbwachs demonstra o caráter coletivo da percepção. O caso limite citado pelo sociólogo é o de Ludwig van Beethoven (1770-1827) que, se inexistisse um código musical compartilhado, não conseguiria compor devido à sua deficiência auditiva. Esse exemplo, por conta de seu aspecto paradoxal, é chave para o estudo de Halbwachs, pois evidencia que não existe memória individual que não seja, de alguma forma e simultaneamente, compartilhada e coletiva. Beethoven, ao que tudo indicava, poderia ser tomado enquanto um sujeito isolado e um gênio por essência, o que seria uma explicação fácil e limitada; mais interessante, contudo, é perceber como ele participou de uma memória cultural coletiva, e isso quer dizer que a memória individual existe somente a partir do cruzamento de muitas outras.

É importante notar que, na argumentação de Halbwachs, não há oposição, e sim uma relação essencial entre memória individual e memória coletiva. No segundo texto do livro, "Mémoire individuelle et mémoire collective", o autor expande essa ideia e afirma que só conseguimos ter memória das coisas quando nos colocamos no ponto de vista de um ou mais grupos, quando contatamos uma ou mais correntes de pensamento coletivo. E, questão fundamental, "uma 'corrente de pensamento' social, normalmente, 
é tão invisível quanto a atmosfera que respiramos"; "somente reconhecemos sua existência, na vida normal, quando resistimos a ela". ${ }^{71}$ Nessa relação entre individual e coletivo, o suporte de uma memória não precisa ser necessariamente material; sensações, emoções, medos, tabus, todos são fatores que conectam a memória de um indivíduo a um coletivo, são sombras que se projetam sobre qualquer um, mesmo que de forma imperceptível. Usando termos metafóricos, assim se exprime o autor: "da mesma forma que é preciso introduzir um germe no meio saturado para que ele cristalize, o mesmo ocorre com esse conjunto de testemunhos exteriores a nós, é preciso lançar uma semente de rememoração para se obter uma massa consistente de lembranças". ${ }^{72}$ De acordo com Halbwachs, como a lembrança aparece por conta do efeito de séries de pensamentos coletivos emaranhados, muitas vezes é difícil identificar sua origem, daí porque pensamos que a memória individual pode ser independente. Isso, contudo, seria o mesmo que - outra metáfora - "supor que um objeto pesado, suspenso no ar por uma quantidade de fios finos e entrecruzados, esteja no vazio, sustentado por si mesmo". 73

Tais reflexões vão ser aprofundadas nos textos sobre "Mémoire collective et mémoire historique" e "La mémoire collective et le temps"; neles, Halbwachs aborda temas como, por exemplo, a relação entre memória de grupo e memória nacional. Segundo o autor, ao longo da vida, uma pessoa participa de um coletivo nacional; este é como um teatro no qual certo número de memórias é compartilhado, mas quase nunca de forma direta. Sempre se conhece o passado nacional através de testemunhos, relatos ou documentos, principalmente de pessoas que estiveram envolvidas nos fatos mais relevantes. Ou seja, nesse caso, a relação coletivo/individual assume uma dimensão quase inviável, pois sempre é necessário se referir às memórias dos outros para ter alguma memória nossa; sem isso, é impossível o pertencimento nacional. Todos têm uma "bagagem de recordações históricas" que pode ser aumentada pela conversa com os outros ou pela leitura; invariavelmente, se trata sempre de uma memória emprestada, de uma memória que deixou marcas profundas, seja pela mudança que promoveu em alguma instituição, seja pela tradição que manteve viva em um grupo. Interessante é notar que Halbwachs entende essa bagagem como composta de noções e símbolos representados de forma popular, de forma inteligível e transmissível; é impossível se

\footnotetext{
${ }^{71}$ Maurice Halbwachs. La mémoire collective. Op. cit., p. 65 e p. 70.

${ }^{72}$ Maurice Halbwachs. La mémoire collective. Op. cit., p. 55.

${ }^{73}$ Maurice Halbwachs. La mémoire collective. Op. cit., p. 96.
} 
lembrar deles com precisão, mas é viável utilizá-los para compor um conjunto de referências mais amplo. ${ }^{74}$

A relação dos indivíduos com os acontecimentos e marcos históricos, assim, sempre ocorre de forma estranha, porque somente é possível conectar a vida presente a um passado nacional através da condição inicial de sair completamente de si mesmo; dessa maneira, a dinâmica fundamental da memória se perde. No pensamento de Halbwachs, um aspecto não deve ser negligenciado, a fim de evitar confusões: ele se colocava em posição oposta ao que se praticava, correntemente à época, como história factual e personalista. Nesse sentido, e apesar das críticas que recebeu de Marc Bloch (1886-1944) por conta de seu livro de estreia, Les cadres sociaux de la mémoire (1925), o sociólogo se aproxima, mesmo que por caminhos bastante diversos, dos combates feitos pela primeira geração da Escola dos Annales a uma historiografia ortodoxa e historicista - havia, portanto, do outro lado, um adversário comum. Dessa forma, ao defender que a memória se baseia não na história aprendida, mas na vivida, Halbwachs deixa claro que por história não se pode entender somente uma sucessão de datas e eventos, personalidades e épocas desconexas; é preciso compreendê-la como tudo aquilo que, pensado a partir das correntes de pensamento, "faz um período se distinguir de outros". Assim, sua constatação é clara: "os livros e narrativas apenas nos apresentam, em geral, um quadro bem esquemático e incompleto". Nas narrativas nacionais, os eventos do passado, transformados em imagens, perpassam as consciências individuais; o problema é que, ao tomar conhecimento desse passado de dimensão coletiva, é possível ser englobado por um esquema de entendimento que foi elaborado a partir de, como disse Paul Ricoeur, "um olhar trazido de lugar nenhum". ${ }^{75}$ Logo, o contato com a memória coletiva é perdido por conta de uma generalização preocupada em captar intensos momentos de ruptura, buscar transformações e fazer

\footnotetext{
${ }^{74}$ Maurice Halbwachs. La mémoire collective. Op. cit., pp. 98-99. Paul Ricoeur, comentando o texto de Halbwachs, ressalta certa tensão existente nessa relação entre memória pessoal e a história exterior: "no início, certa violência vinda do exterior é exercida sobre a memória. A descoberta do que se chamará de memória histórica consiste numa verdadeira aculturação à exterioridade. Essa aculturação é a de uma familiarização progressiva com o não familiar, com a inquietante estranheza do passado histórico". Paul Ricoeur. A memória, a história, o esquecimento. Tradução de Alain François et al. Campinas: Editora da Unicamp, 2007, p. 405.

75 “Assim, o texto de Maurice Halbwachs descreve uma curva: da história escolar, exterior à memória da criança, elevou-se para uma memória histórica que, idealmente, funde-se na memória coletiva que, por sua vez, ela amplia, e in fine desemboca numa história universal que se interessa pelas diferenças de época e reabsorve as diferenças de mentalidade, sob um olhar trazido de lugar nenhum. A história, assim reconsiderada, merece ainda o nome de 'memória histórica'? Memória e história são condenadas a uma coabitação forçada?’. Paul Ricoeur. A memória, a história, o esquecimento. Op. cit., p. 408.
} 
segmentações. É como se, a fim de fomentar identificação com um conjunto, se criasse um "meio artificial, exterior a todos os pensamentos pessoais, mas que os envelopa, um tempo e um espaço coletivos, em uma história coletiva". ${ }^{76}$

Indo contra essa história esquemática, Halbwachs vai pensar uma memória coletiva que esteja em relação com "correntes de pensamento", com "camadas do passado" que afloram em mais de um lugar do presente. Assim, ao invés de mudanças esquemáticas e incompletas, ele pensa em uma história mais próxima do vivido, da qual a memória emerge através de uma relação entre o individual e o coletivo, sendo que nenhum desses dois polos é autorreferente. Memória coletiva e história, então, não são termos sinônimos; da mesma forma, é inviável falar em uma memória histórica, pois isso seria a junção de fatores distintos em um mesmo termo. Para o sociólogo, se é possível dizer que a história é o conjunto de fatos de maior destaque na memória dos homens, essa operação só é feita a partir de escolhas, comparações e classificações que escapam aos interesses vividos. Mais ainda, diz que a escrita da história só passa a ser uma necessidade a partir do momento em que o passado se afasta demais, o que cria o risco de perda de testemunhos e tradições; ou seja, é a partir do momento em que o passado deixou de ser memória social, deixou de ser sustentado por um grupo e não é mais uma corrente de pensamento, que ele é envelopado pelos esquemas da história. Dessa maneira, a história factual e progressiva surgiria exatamente da interrupção do fluxo de memória, da fragmentação do passado em períodos que se fecham em si mesmos como um todo. Como diz o autor:

A história, que se coloca fora dos grupos e acima deles, não hesita em introduzir, na corrente dos fatos, divisões simples, cujo lugar é fixado de uma vez por todas. Ela não obedece, assim fazendo, a nada além de uma necessidade didática de esquematização. Parece que considera cada período como um todo, independente, em grande parte, daquele que precede e daquele que se segue, porque ela tem uma obra, boa, má ou indiferente, a realizar. Na medida em que essa obra não está realizada, na medida em que tais situações nacionais, políticas, religiosas, não desenvolveram todas as consequências que comportam, a despeito das diferenças de idade, os jovens como os homens de idade se encerram no mesmo horizonte. ${ }^{77}$

\footnotetext{
${ }^{76}$ Maurice Halbwachs. La mémoire collective. Op. cit., p. 102, p. 105 e p. 107.

77 « L'histoire, qui se place hors des groupes et au-dessus d'eux, n'hésite pas à introduire dans le courant des faits des divisions simples, et dont la place est fixée une fois pour toutes. Elle n'obéit pas, ce faisant, rien q'à un besoin didactique de schématisation. Il semble qu'elle envisage chaque période comme un tout, indépendant en grande partie de celle qui précède et de celle qui suit, parce qu'elle a une oeuvre, bonne, mauvaise, ou indifférent, à accomplir. Tant que cette oeuvre n'est point achevée, tant que telles situations nationeles, politiques, religieuses, n'ont point développé toutes les conséquences qu'elles comportaient en dépit des différences d'âge, les jeunes gens comme les hommes âgés s'enfermeraient dans le même horizon ». Maurice Halbwachs. La mémoire collective. Op. cit., pp. 132-133.
} 
A preocupação de Halbwachs, portanto, é com a escrita de uma história que seja feita sem substrato humano, na qual a divisão do passado se faça a partir de ideias e interesses pré-estabelecidos, o que faz com que as memórias coletivas sejam repartidas de forma arbitrária. É necessário, um dado fundamental, não esquecer que estas reflexões foram escritas no período do entre guerras e da ascensão do nazismo; ou seja, a crítica a uma história esquemática, irregular e incerta, e a defesa de uma memória coletiva baseada em um desenvolvimento contínuo e compartilhado têm eminente caráter político. É como se, a partir da experiência vivida e do compartilhamento de memórias, fosse possível recusar operações arbitrárias com o passado e questionar tradições inventadas. Os grupos, assim, podem compreender a pluralidade de sua memória, entender mudanças e semelhanças com os tempos anteriores, aderir a correntes de pensamento, marcar seu próprio ritmo de transformação e conhecer o passado a partir de si mesmos, e não somente aceitá-lo como uma unidade, uma imposição vinda de fora. Nas palavras do autor: "o grupo, no momento em que examina seu passado, sente bem que continua o mesmo e toma consciência de sua identidade através do tempo". ${ }^{78}$ Com isso, Halbwachs não nega a história, mas uma forma específica de entendê-la; seu questionamento assume-se, antes de qualquer coisa, como um apelo democrático, um questionamento ao autoritarismo. A memória coletiva, assim, é um meio para se fazer a resistência, para se combater os mitos políticos.

Comentando o tema da complexidade que envolve os contatos entre memória e história, Eclea Bosi, inspirada pelas ideias de Maurice Halbwachs - sobretudo para as relações entre memória coletiva e história nacional -, alerta para o fato de que parece haver "sempre uma narrativa coletiva privilegiada no interior de um mito ou de uma ideologia. E essa narrativa explicadora e legitimadora serve ao poder que a transmite e difunde". Segundo a mesma autora, a memória de acontecimentos políticos e figuras notáveis tende a ser estabelecida a partir de aglomeração de recordações factuais enlaçadas por pressupostos ideológicos, algo semelhante à história envelopada e esquemática da qual fala Halbwachs. Tal construção acerca do passado evidencia que somente aquilo que possui significado para determinadas pessoas ou grupos sociais é passível de se transformar em objeto de memória, em matéria para uma narrativa histórica - assim, “uma das faces da memória pública tende a permear as consciências

\footnotetext{
${ }^{78}$ Maurice Halbwachs. La mémoire collective. Op. cit., p. 139.
} 
individuais. É preciso sempre examinar matizando os laços que unem memória e ideologia”. ${ }^{79}$ Com o segundo imperador do Brasil esses laços são variados: fragmentos de sua vida e de sua atuação política são costurados e arranjados para elaborar uma determinada imagem de governante, que pode ser, de acordo com interesses específicos de quem seleciona a memória e detém condições suficientes para construir o discurso, positiva ou negativa. Ao esmiuçar as representações de d. Pedro II, transformando-as em documentos históricos, é possível lançar luz aos arranjos que sustentam sua memória; compreender, então, o grau de estranhamento que existe na ligação estabelecida entre memória nacional e as correntes de pensamento.

Um aspecto interessante, no que diz respeito às relações entre história e memória, é que as mudanças na definição de uma delas traz consigo, invariavelmente, transformações na definição da outra. Isso fica claro quando se pensa, tendo em mente os textos de Maurice Halbwachs, nos estudos feitos sobre o tema a partir da segunda metade do século XX. Na historiografia contemporânea, um dos trabalhos mais importantes e difundidos acerca da relação entre história e memória é Lieux de mémoire, obra coletiva coordenada pelo historiador Pierre Nora, cujo primeiro volume foi publicado em 1984. Tal obra foi concebida para propor questionamentos a respeito de ideias consolidadas no imaginário francês, tais como nação, pátria e república; tudo isso feito, importante lembrar, com as comemorações do bicentenário da Revolução Francesa raiando no horizonte. Trata-se de um contexto, portanto, que impunha a necessidade de balanços e clamava por uma releitura da historiografia. $\mathrm{Na}$ abertura do tomo primeiro, intitulado A República, Nora escreveu o clássico ensaio "Entre história e memória: a problemática dos lugares", no qual deu a tônica e as referências teóricas de toda a obra. Na sua linha de raciocínio, memória e história figuram como elementos quase opostos, mesmo que, como não poderia deixar de ser, diretamente relacionados. A história aparece como o conhecimento necessário para racionalizar e criticar os excessos memorialísticos, revelando que, para além dos espaços evidentes de celebração, a memória, com todos seus apelos, estava difundida por diversos lugares. Em outras palavras, para Nora, a história precisaria retirar a memória de certo inconsciente

\footnotetext{
${ }^{79}$ Eclea Bosi. O tempo vivo da memória: ensaios de psicologia social. São Paulo: Editorial Ateliê, 2003, p. 18 e pp. 21 e 22.
} 
coletivo e, de forma desmistificadora, evidenciar seu caráter de constructo políticosocial. $^{80}$

Os lugares da memória - levando em conta que, na concepção de Pierre Nora, é preciso entender essas palavras em sentido amplo - são arquivos, monumentos, desfiles, feriados, festas, emblemas e comemorações, assim como, também, discursos elogiosos, dicionários, obras literárias, instituições, etc. Por conta dessa multiplicidade de manifestações, percebe-se que, como afirma o historiador, trata-se sempre de uma memória que não se opõe ao esquecimento, porque o engloba, assim como não se confunde com as lembranças em si, pois estas já estão subentendidas na própria constituição dos lugares. A memória, na lógica de Pierre Nora, não se limita a manifestações pessoais ou ao esquecimento; tudo o que compõe a celebração do passado, mesmo aquilo que falta, já está entendido no conceito de "lugares de memória". Está-se lidando, então, com lugares-cruzamentos, encruzilhadas atravessadas por dimensões múltiplas - históricas, etnográficas, psicológicas, políticas. Configura-se um fenômeno complexo, que se manifesta de diversas formas, em diversos lugares, mas que jamais deixa de ser um "lugar", jamais prescinde de um suporte. A complexidade da ideia de lugar está no fato de que se trata mais de uma combinação de fatores do que de uma materialidade; é um "conjunto de estratégias", algo que "vale menos pelo que é do que pelo que dele se faz". Nesse sentido, se percebe a "dimensão literária dos lugares de memória", na qual, além de identificar o suporte, o interesse fundamental é esclarecer o sentido da combinação e o engajamento pessoal de quem opera com o passado. ${ }^{81}$ Tome-se, como exemplo, os nomes das ruas, algo tão cotidiano e tão pouco pensado. $\mathrm{O}$ decreto de nomeação, a placa que fica na esquina, a região da cidade onde está localizada a via, os nomes que foram esquecidos para que um fosse escolhido, tudo isso compõe um lugar de memória; no entanto, não é o bastante, pois é preciso

\footnotetext{
${ }^{80}$ Ressalta-se que, segundo Paul Ricoeur, no texto de Pierre Nora, "a memória, da qual se fala no começo, não é a capacidade geral investigada pela fenomenologia, mas uma configuração cultural [...]; e a história não é a operação objetiva abordada pela epistemologia, mas a reflexão de segundo grau para a qual, muitas vezes, se reserva, na França, o termo 'historiografia', no sentido de história da história". Paul Ricoeur. A memória, a história, o esquecimento. Op. cit., p. 413.

${ }^{81}$ Pierre Nora. "Entre mémoire et Histoire: la problématique des lieux". Op. cit., p. VIII. A complexidade dos lugares da memória está em que, conforme argumenta Paul Ricoeur, eles acumulam três sentidos: material, simbólico e funcional. "O primeiro fixa os lugares de memória em realidades que consideraríamos inteiramente dadas e manejáveis; o segundo é obra de imaginação e garante a cristalização das lembranças e sua transmissão; o terceiro leva ao ritual que, no entanto, a história tende a destruir, como se vê com os acontecimentos fundadores ou com os acontecimentos espetáculos, e com os lugares refúgios e outros santuários". Paul Ricoeur. A memória, a história, o esquecimento. Op. cit., p. 416.
} 
operacionalizar esses fatores: talvez existam celebrações em homenagem à pessoa que dá nome à rua, na placa podem constar informações biográficas ou profissionais, às vezes há alguma estátua ou monumento. Além disso, a homenagem precisa ser, de alguma forma, entendida como relevante; do contrário, podem surgir propostas para, por exemplo, mudar o nome da via. Trata-se de uma operação que passa quase incógnita, mas que, para ter o mínimo de profundidade, precisa ser operada e sustentada por certas práticas. Afinal, lembrando as palavras de Maurice Halbwachs, apenas se anda sozinho pelas ruas em aparência; sempre estamos acompanhados, de alguma maneira, de memórias que temos em comum com outras pessoas. ${ }^{82}$ A desconstrução dos "lugares de memória", assim, passa por tornar claro o arranjo de certas operações com o passado, evidenciar aquilo que faz com que determinadas memórias apareçam ao presente de maneira quase natural. Da mesma forma que as placas de esquina, quantos outros desses lugares não passam despercebidos? Nesse sentido, Beatriz Sarlo é bastante enfática: "O questionamento do que é costumeiro é a condição de um conhecimento dos objetos mais próximos, que ignoramos justamente porque permanecem ocultos pela familiaridade que os encobre. Isso vale também para o passado". ${ }^{83}$

Mesmo a celebração de uma data pátria, algo que pode parecer normal, nada tem de evidente. Quantos arranjos estão envolvidos nisso que surge tão necessário? Tome-se o emblemático caso da Revolução Francesa. No primeiro centenário, em 1889, a revolução foi rememorada pelo viés da república, como o movimento que derrubou a sociedade do Antigo Regime; no final do século XIX, a Terceira República francesa ainda estava lidando com os embates e atribulações da Guerra Franco-Prussiana e da Comuna de Paris, daí porque se celebrava 1789 como momento de fundação de um regime político, não como período de guerras e conflitos sociais. Em 1939, no sesquicentenário, o contexto era completamente outro; às vésperas da Segunda Guerra Mundial, a Revolução Francesa era tomada como símbolo nacional, superação das diferenças internas, resistência às ofensivas externas e mobilização bélica, o que vai ser potencializado ao máximo pela subsequente ocupação nazista. ${ }^{84}$ No bicentenário, em

\footnotetext{
${ }^{82}$ Maurice Halbwachs. La mémoire collective. Op. cit., p. 53.

${ }^{83}$ Beatriz Sarlo. Tempo passado. Op. cit, p. 41.

${ }^{84}$ Em crônica de fevereiro de 1938, o cineasta Jean Renoir (1894-1979), ao comentar seu filme La Marseillaise, realizado entre 1937 e 1938, com grande lucidez e por um viés de esquerda, mostra como uma obra sobre a Revolução podia ser extremamente atual. Diz ele: "Perseguimos um objetivo muito claro e muito simples: apresentar ao público um filme sobre a Revolução Francesa, sobre a primeira parte da Revolução, porque, devido às aproximações fáceis de fazer com a situação atual, devido às preocupações e ideias dos homens daquela época, pensamos que esse filme podia parecer atual. Seria
} 
1989, no fim do breve século $X X$, no crepúsculo da era dos extremos, a revolução vai ser celebrada, após terrível histórico de guerras, ditaduras, massacres e desmantelamento de Estados nacionais e impérios coloniais, pelo viés da Declaração dos Direitos do Homem e do Cidadão, uma tentativa de dar voz aos que não tinham publicidade - ou, também, será anticelebrada, como na bela cena do filme Les amants $d u$ Pont-Neuf (1991), de Leos Carax, quando, à medida em que estouram os fogos de artifício do bicentenário, um morador de rua e uma pintora em vias de ficar cega, os tais amantes da ponte (aliás, ao longo do filme, a Pont-Neuf, a mais antiga de Paris, está fechada para reformas), embriagados e loucos, vivem uma efetiva catarse que nada tem a ver com a celebração nacional. ${ }^{85}$ Em suma, nada há de evidente em cultuar a pátria, a

impossível para nós fazer uma fita sobre a situação política atual, isso poderia levantar polêmicas e ser desagradável para um público que vai ao cinema simplesmente para se distrair. Mas pode-se dizer que os homens da Revolução começaram a se dividir como os de hoje e encontra-se neles, um pouco, a preocupação dos franceses de agora. Uma maneira de lançar um pouquinho de luz sobre certos problemas que não se pode abordar no cinema, era então fazer um filme sobre a Revolução Francesa. [...] Quando se faz um filme histórico, melhor que ele o seja... Mas, a nosso ver, a verdade sobre os fatos, das coisas, dos personagens reside numa certa maneira de torná-los vivos". Jean Renoir. "A forma e o espírito de $L a$ Marseillaise". In: O passado vivo. Tradução de Raquel Ramalhete. Rio de Janeiro: Nova Fronteira, 1991, pp. 44-46.

Marie-Claire Lavabre. "Usages du passé, usages de la mémoire". In: Revue française de science politique. 44e année, $\mathrm{n}^{\mathrm{o}} 3$, 1994, pp. 480-493; pp. 488 e 489 . Colsultado no site: http://www.persee.fr/web/revues/home/prescript/article/rfsp_0035-2950_1994_num_44_3_394841,

Como diz Eric J. Hobsbawm, sobre os significados e interpretações da Revolução Francesa, houve uma efetiva "refração da Revolução através de prismas políticos contemporâneos"; "em resumo, todos tiveram a sua Revolução Francesa, e o que foi nela celebrado, condenado ou rejeitado dependeu não da política ou da ideologia de 1789, mas do tempo e lugar dos próprios comentaristas". Eric Hobsbawm. Ecos da Marselhesa: dois séculos reveem a Revolução Francesa. Tradução de Maria Celia Paoli. São Paulo: Companhia das Letras, 1996, pp. 82-83. No que diz respeito à anticelebração da memória, tal como comentada há pouco, é interessante notar que ela pode assumir várias formas e facetas; por vezes, pode até ser uma iniciativa oficial. Sobre esse assunto, o filósofo Renato Janine Ribeiro, em um intrigante ensaio sobre o Real, a moeda adotada no Brasil a partir de 1994, mostra como, em vários aspectos simbólicos que o envolvem, tentou-se negar a memória do período anterior à sua circulação. A começar pelo nome, o Real dava a entender que aquilo que viera antes - o governo Collor e a galopante inflação tinha algo de irreal e imaginário; assim, "o que o novo nome indica é que a moeda pretende sair da fantasia e ingressar no mundo das coisas como elas são". Com isso, de certa forma, conseguia-se obliterar parte dos conflitos anteriores e criar uma estabilidade financeira e imaginária; missões nas quais, aliás, a nova moeda foi bem sucedida. Um símbolo concreto dessa anticelebração foi que, ao contrário do que ocorria antes, não foram personalidades históricas que estamparam as novas notas, e sim animais da fauna brasileira. Uma fauna, não sem motivo, de aparência sugestivamente pré-colonial; anterior, portanto, à própria História do Brasil (entendida, esta, em um sentido conservador e tradicional). Como diz o autor: "De modo que o real, assim concebido, é sonho: o sonho de que possamos nos desfazer do passado simplesmente relegando-o à esfera da fantasia e do erro ou errância, e apostando, como fundamento, na natureza prévia ao civilizado". O mais interessante é perceber como, após a estabilização político-econômica ser consolidada, a anticelebração perde o sentido e a história volta a figurar, se não nas notas, ao menos no novo conjunto de moedas. No entanto, ao contrário do que se poderia esperar, haja em vista as mudanças na historiografia contemporânea e a presença de um sociólogo na presidência, é a história oficial a que aparece nas moedas apresentadas em 1998 (Cabral, Tiradentes, d. Pedro I, Deodoro e, figura mais representativa do Estado, Rio Branco). Assim, aquilo que fora legado ao esquecimento, volta com carga cheia; no espaço de poucos anos, vai-se da anticelebração à celebração. Ou seja, "depois do esvaziamento da imagem humana promovido pelo papel-moeda de 1994, a história 
nação ou a república; são sempre arranjos preenchidos literariamente e operacionalizados a partir do presente. No caso brasileiro, como veremos, entre os anos 1920 e 1940, tempos de crise do regime republicano, d. Pedro II foi referência fundamental na tessitura da memória e na celebração do passado. Cada um de seus intérpretes tomou dele aquilo que bem entendia como importante e deu a isso ares de memória coletiva.

Em sua argumentação, feita nas vésperas do bicentenário da Revolução Francesa, Pierre Nora parte da ideia de que os meios de memória foram destruídos no mundo contemporâneo; foi em um contexto contraditório e conturbado, marcado pelo surgimento de novas nações e etnias, pela midialização e mundialização, democratização e massificação, que ficou evidente o sentimento de ruptura com o passado, de esfacelamento da memória. O autor vê o seu contexto como um tempo de aceleração, no qual o modo de percepção histórica foi dilatado e, ao invés das tradições recolhidas na herança das memórias, é a própria "película efêmera da atualidade" o que molda o olhar lançado sobre o passado. Dessa forma, o que se procura na história, aquilo que se busca avidamente, é um passado nostálgico, que forneça rituais (entendido, aqui, como algo que possa ter amplo e estável significado coletivo) para uma sociedade sem rituais, o sagrado para o dessacralizado, o diferenciado e particular para uma sociedade nivelada e na qual não se reconhecem mais os indivíduos. Foi isso a instabilidade entre o desejo de pertencimento e a realidade do afastamento - o que deixou evidente o desgaste das grandes "sociedades-memórias" e das "ideologiasmemórias"; foi isso que fragmentou o passado em uma infinidade de pequenas histórias. $^{86}$

Nessa busca por um passado perdido, a memória e a história terminaram por se adequar uma à outra, ambas representando a busca por algo ideal, por tradições que poderiam se sustentar a partir da frágil película do presente. De acordo com Nora, seria por aquilo que falta que se formulou uma concepção de memória histórica, que se

dos homens volta à moeda sob sua forma mais convencional. Não estranha que o nosso passado, quando as instituições assim o celebram, desperte tão pouco interesse". Renato Janine Ribeiro. "O real e seu imaginário ou $\mathrm{O}$ fim da esquerda iluminista". In: A sociedade contra o social. Op. cit, pp. 65-91.

${ }^{86}$ Pierre Nora. "Entre mémoire et Histoire: la problématique des lieux". Op. cit., p. XVIII e pp. XXIV e XXV. Sobre esse assunto, leia-se o interessante comentário de Beatriz Sarlo, que ressalta os perigos da pluralidade: "quando ninguém está disposto a aceitar a verdade de uma história (o que Benjamin denominou 'fatos' reificados), todos parecem mais dispostos à crença nas verdades de histórias no plural (o plural: essa inflexão no paradigma que alcançou a mais alta categoria, o que é muito bom, mas também se propõe como solução verbalista a qualquer questão conflituosa)". Beatriz Sarlo. Tempo passado. Op. cit, p. 40. 
buscou no passado alguns traços de identidade. Há, nisso tudo, nessa forma de relação entre passado e presente, um paradoxo, uma proporção invertida: à medida que a memória se torna mais fragmentária - ou, melhor dizendo, que se perdem os princípios explicativos únicos ${ }^{87}$-, ela se infla hipertroficamente; não sem motivo, portanto, que, pela urgência e necessidade de se reconhecer no passado, uma historiografia de matriz detalhista e diversificada ganhou, estabelecida sobre narrativas muito bem elaboradas e espalhada por outros meios de comunicação além dos impressos, uma ampla difusão e uma penetração profunda, em um nível que jamais havia conhecido. Há uma explosão de passado; conforme diz Nora, "o fim da história-memória multiplicou as memórias particulares que reclamam sua própria história". 88

Como comentado anteriormente, não se pode esquecer que a memória tem uma dupla face; logo, se, por um lado, muitos dos esquecidos do passado conquistam um louvável espaço nos estudos historiográficos, por outro, abriu-se a brecha para o culto e celebração da memória. Daí porque é possível entender o gosto excessivo pelo passado como sinal de uma crise; colar-se ao confortável e aparentemente absoluto, ao que, erigido sobre o especifico, surge como um todo, é tarefa mais gratificante e aprazível que o esforço da crítica e do relativo. Quando o chão sob os pés balança, nesse momento é que se busca algo no que se agarrar; quando os interesses estão majoritariamente voltados para um futuro incerto, os olhos lançam-se à cata do passado, querem evitar o horror do esquecimento. Paralelamente a isso, como diz Julio Pimentel Pinto, há certa insensibilidade, por assim dizer, dos historiadores para com as demandas pelo passado; dessa maneira, a historiografia profissional "sufoca a memória e força o surgimento de lugares de memória, espaços de culto e recuperação de um passado deserdado pelo ofício crítico do historiador". 89

Por conta da crise e da confusa demanda por passado, Pierre Nora trilha o caminho oposto ao da aproximação entre história e memória, realizando esforços em diferenciar, teórica e praticamente, cada uma das duas. É por flagrar contradições e ausência de parâmetros, por entender os riscos envolvidos na fragmentação e nos usos do passado, que o historiador se preocupa em conceituar uma memória que está

\footnotetext{
${ }^{87}$ Pierre Nora. "Entre mémoire et Histoire: la problématique des lieux". Op. cit., p. XXXII.

88 "La fin de l'histoire-mémoire a multiplié les mémoires particulièrres qui réclament leur propre histoire". Pierre Nora. "Entre mémoire et Histoire: la problématique des lieux". Op. cit., pp. XXVII e XXVIII. Sobre a difusão da história pelos meios de comunicação, ver, por exemplo, Georges Duby. "Da televisão". In: A história continua. Tradução de Clóvis Marques. Rio de Janeiro: Jorge Zahar; Ed. UFRJ, 1993, pp. 129-135.

${ }^{89}$ Julio Pimentel Pinto. Uma memória do mundo. Op. cit., p. 297.
} 
difundida por diversos lugares, e em traçar os limites existentes entre história e memória, reconhecendo na primeira a necessidade de fazer críticas à segunda. Diferente do que se poderia imaginar no calor das celebrações, não se trata de sinônimos:

Memória, história: longe de ser sinônimas, nós tomamos consciência que tudo as opõem. A memória é a vida, sempre sustentada por grupos viventes e, em razão disso, ela está em evolução permanente, aberta à dialética da lembrança e da amnésia, inconsciente de suas deformações sucessivas, vulnerável a todas as utilizações e manipulações, susceptível de longas latências e súbitas revitalizações. A história é a reconstrução sempre problemática e incompleta do que não é mais. A memória é um fenômeno sempre atual, um laço vivido no presente eterno; a história, uma representação do passado. Porque ela é afetiva e mágica, a memória apenas se acomoda nos detalhes que a confortam; ela se nutre de lembranças vagas, telescópicas, globais ou flutuantes, particulares ou simbólicas, sensível a todas transferências, invólucros, censuras ou projeções. A história, posto que operação intelectual e laicizante, clama por análise e discurso crítico. A memória instala a lembrança no sagrado, a história a retira, ela sempre prosaiza. A memória emerge de um grupo que ela une, o que quer dizer, como Halbwachs o fez, que há tanto de memórias quanto de grupos; que ela é, por natureza, múltipla e desacelerada, coletiva, plural e individualizada. A história, pelo contrário, pertence a todos e a ninguém, o que lhe dá vocação ao universal. A memória se enraíza no concreto, no espaço, gesto, imagem e objeto. A história se liga apenas às continuidade temporais, às evoluções e aos indícios das coisas. A memória é um absoluto e a história só conhece o relativo. ${ }^{90}$

De acordo com o autor, elemento fundamental para esclarecer isso tudo é a prática de uma história consciente, ou, em outras palavras, uma história que reconheça sua própria historicidade, seu intrínseco aspecto historiográfico. Vai se revelando, assim, qual seria a grande sagacidade dos "lugares de memória": sua capacidade de se colocar além da história, além das referências e das possibilidades de crítica. Segundo Nora, diferente de todos os objetos da história, os "lugares de memória" não têm

\footnotetext{
${ }^{90}$ « Mémoire, histoire: loin d'être synonymes, nous prenons conscience que tout les oppose. La mémoire est la vie, toujours portée par des groupes vivants et à ce titre, elle est en évolution permanente, ouverte à la dialetique du souvenir et de l'amnésie, inconsciente de sés déformations successives, vulnérable à toutes lês utilisations et manipulations, suceptible de longues latences et soudaines revitalisations. L'histoire est la reconstruction toujours problématique et incomplète de ce qui n'est plus. La mémoire est um phénomène toujours actuel, um lien vécu au present éternel; 1'histoire, une représentation du passe. Parce qu'elle est affective et magique, la mémoire ne s'accommode que des détails qui la confortent; elle se nourrit de souvenirs flous, télescopants, globaux ou flottants, particuliers ou symboliques, sensible à tous les transferts, écrans, censure ou projections. L'histoire, parce que opération intellectuelle et laïcisante, appele analyse et discours critique. La mémoire installe le souvenir dans le sacré, l'histoire l'en débusque, elle prosaïse toujours. La mémoire sourd d'un groupe qu'elle soude, ce qui revient à dire, comme Halbwachs l'a fait, qu'il y a autant de mémoires que de groupes; qu'elle est, par nature, multiple et démultipliée, collective, plurielle et individualisée. L'histoire, au contraire, appartient à tous et à personne, ce qui lui donne vocation à l'universel. La mémoire s'enracine dans le concret, dans l'espace, le geste, l'image et l'object. L'histoire ne s'attache qu'aux continuités temporelles, aux évolutions et aux rapports dês choses. La mémoire est un absolu et l'histoire ne connaît que le relatif ». Pierre Nora. "Entre mémoire et Histoire: la problématique des lieux". Op. cit., p. XIX.
} 
referentes na realidade. Ou, melhor dizendo, eles são, por si só, seus próprios referentes, signos que remetem apenas à sua própria referência; signos, portanto, em estado puro daí porque assumem uma aura de eternidade, parecem existir desde sempre e ser inquebrantáveis. Ao mesmo tempo em que se esforçam por conter o que é fluido, materializar o que não tem matéria, enfeixar o máximo de significados no mínimo de signos, "fica claro, e é isso o que os torna tão apaixonantes, que os lugares de memória só vivem de sua aptidão à metáfora, nas incessantes voltas de suas significações e nos emaranhados imprevisíveis de suas ramificações". Assim, por aparentemente escaparem da história é que se constituem enquanto "lugares de memória"; ou, trocando em miúdos, "o que os constitui é um jogo entre a história e a memória, uma interação de dois fatores que acaba por lhes subdeterminar reciprocamente". Nesse jogo, para estabelecer o lugar de memória, a memória recita e a história escreve. ${ }^{91}$

Cabe ao historiador, nessa lógica de pensamento, seguir sentido contrário, negar a autorreferência, se inserir na historiografia e assumir um posicionamento. Antes de se prender a uma tradição, é preciso, em nome de uma consciência crítica, questionar essa mesma tradição. Antes de se encantar pelo passado e pela memória, é preciso criar distância e perspectiva. Trata-se de uma "dinâmica interna do princípio crítico", que desestabiliza o lugar social e intelectual do historiador e evita que ele se perca no paradoxo da hipertrofia memorialística:

O estudos dos lugares de memória se encontra, assim, no cruzamento de dois movimentos que lhe dão, na França e atualmente, seu lugar e seu sentido: por um lado, um movimento puramente historiográfico, o momento de um retorno reflexivo da história sobre ela mesma; de outro, um movimento propriamente histórico, o fim de uma tradição de memória. ${ }^{92}$

Dessa forma, o olhar pode se lançar para aquilo que de mais simbólico há no passado, os resíduos nos quais subsiste uma comemoração, sem, com isso, estar ludibriado por uma necessidade urgente de retomar o que foi perdido. Cria-se uma dupla ação: historiográfica e histórica, intelectual e pragmática, pensamento e ação. Tendo consciência do cruzamento dos dois movimentos, a memória e a história não se confundem, nem se negam; de maneira diversa, se inter-relacionam de forma criativa e

\footnotetext{
${ }^{91}$ Pierre Nora. "Entre mémoire et Histoire: la problématique des lieux". Op. cit., p. XXI, pp. XXXIVXXXV, p. XLI, p. XXI e p. XXXVIII.

92 «L'étude des lieux de mémoire se trouve ainsi à la croisée de deux mouvements qui lui donnent, en France et aujourd-hui, sa place et son sens: d'une part um mouvement purement historiographique, le moment d'un retour réflexif de l'histoire sur elle-même; d'aure part um mouvement proprement historique, la fin d'une tradition de mémoire ». Pierre Nora. "Entre mémoire et Histoire: la problématique des lieux". Op. cit., p. XXIII.
} 
consciente. Através desse exercício crítico, o historiador não mistifica o passado; República, Nação e Pátria, da mesma forma que diversas outras ideias e práticas como, por exemplo, d. Pedro II, o rei-cidadão -, podem ser pensadas, não como "lugares de memória", mas como arranjos a serem entendidos em sua tessitura.

Essas colocações podem parecer um tanto enrijecidas e fundadas sobre uma concepção excessivamente crente na racionalidade, mesmo que relativa, da história; podem tomar como opostos - "no coração da história, trabalha um criticismo destruidor da memória espontânea", "a memória é sempre suspeita à história" - fatores que, talvez, sejam complementares; contudo, elas não deixam de ser provocativas em vários aspectos - daí, provavelmente, o seu caráter clássico. Como já ressaltado, faz-se necessário relativizar essa oposição, não entendê-la como consolidada; principalmente, é preciso compreender que se trata, aqui, de uma definição de memória feita a partir de uma concepção de trabalho historiográfico. ${ }^{93}$ Não há, portanto, uma pura e simples oposição; o próprio Pierre Nora afirma que os historiadores e a sociedade precisam, evidentemente, da memória, mas desde que ela seja esvaziada daquilo que a transforma em "lugar de memória". ${ }^{94}$ Toca-se, assim, em um ponto fundamental: da mesma forma que história e memória não são sinônimos, tampouco memória e "lugar de memória" o são. Esse parece ser um dado dos mais importantes na argumentação de Nora: jamais se devem entender os elementos, mesmo que tomados como opostos, de forma isolada; as diferenças entre história e memória só se tornam claras a partir dos arranjos nos quais estão inseridas. Nesse sentido, salta aos olhos um fato interessante: apesar de suas especificidades, as propostas de Maurice Halbwachs e Pierre Nora são bastante próximas. O primeiro, nos anos 1930 e 40, diante de uma história sufocante e arranjada para justificar regimes autoritários, vai em busca de "correntes de pensamentos", "memórias coletivas" e "camadas de passado". O segundo, nos anos 1980, em face de uma historiografia fragmentada pelos excessos memorialísticos, formula a noção de "lugares de memória" em oposição ao exercício crítico do historiador. Cada um, a seu modo e em seu contexto, define suas ideias a fim de negar os desmandos sufocantes vindos do outro lado. Assim, não existe uma concepção de memória sem uma de história, e vice-versa - ou seja, conceitual e praticamente, a memória e a história se

\footnotetext{
93 Marie-Claire Lavabre. "Usage et mésusage de la notion de mémoire”. In: Critique internationale. Année 2000, Vol. 7, Num. 7, p. 50. Consultado no site: http://www.persee.fr/web/revues/home/prescript/article/criti_129078392000 num7 1 1560

${ }^{94}$ Pierre Nora. "Entre mémoire et Histoire: la problématique des lieux". Op. cit., pp. XIX e XX.
} 
retroalimentam. O que Halbwachs e Nora revelam, acima de tudo, não é uma oposição incontornável, e sim a necessidade do equilíbrio.

As reflexões teóricas acerca das relações entre história e memória, sobretudo no que diz respeito à necessidade de um equilíbrio entre elas, a fim de ganharem corpo definido, precisam abordar um caso prático. Nesse sentido, um dos textos mais impressionantes, quando lido pelo viés da memória, é Eichmann em Jerusalém, de Hannah Arendt (1906-1975), cuja primeira publicação em livro se deu no ano de 1963. Trata-se de um relato fundado em visão pessoal, que repercute o sofrimento e o drama de quem narra, mas que, em nenhum momento, deixa de demonstrar profunda preocupação coletiva. É uma abordagem de um acontecimento sem precedentes, no qual diversas expectativas estão em disputa, para o qual terríveis reminiscências foram trazidas à tona. Todos os fatores que tornam a memória tão complexa, portanto, estão dados; é um cruzamento entre passado, presente e futuro, em que o encantamento da memória se faz tentador e arriscado. ${ }^{95}$

A argúcia demonstrada por Hannah Arendt em sua narrativa é notável, tanto que, para ela, o julgamento de Adolf Eichmann (1906-1962), desde o começo permeado por excessiva teatralidade, corria o risco de se tornar um lamentável espetáculo. Havia muita coisa em jogo, muitos sofrimentos e muitas memórias estavam sendo mobilizados; além disso, havia falta de precedentes e complicadas questões em aberto no que diz respeito à legitimidade, jurisprudência e justiça. Era, assim, um evento de confluências: o que viera antes deveria passar por ele, aquilo que viesse depois traria suas marcas. No entanto, nessa tentativa de fazer um marco, de fazer justiça pelo passado e projeções para o futuro, quanto não ficaria de fora; quantas questões, algumas das mais fundamentais e candentes, restariam sem resposta; quantos interesses contemporâneos reforçariam injustiças passadas; quantas ideias contestáveis não seriam reafirmadas e quantas não seriam criadas? Antigermanismo, antiarabismo, antissemitismo, povos com ou sem cultura, concepções de crimes contra a humanidade e a forma de puni-los; todos eram temas espinhosos que poderiam emergir, ou simplesmente desaparecer, a partir da má condução dos acontecimentos. Arendt, que fora para Jerusalém como correspondente da revista The New Yorker, desde o princípio

\footnotetext{
95 Agradeço a Lilia M. Schwarcz que, no exame de qualificação - realizado em 08 de agosto de 2013 -, sugeriu a leitura do livro de Hannah Arendt pela perspectiva da memória.
} 
do relato se incomoda com certos aspectos do tribunal, levanta interrogações e vai levando a argumentação ao limite.

O terror dos atos que estavam sendo julgados se sobrepunha às estratégias do "julgamento-espetáculo", subvertendo, assim, a ideia de fazer dele um exemplo para a juventude israelense; no mais das vezes, o que se conseguia era tornar as situações extremamente vexatórias e humilhantes para as vítimas. Em alguns casos, por exemplo, o julgamento recaía sobre o tema da suposta covardia demonstrada por alguns judeus diante da certeza da morte; teriam, em face de todos os indícios, se comportado como carneiros rumo ao abate. Tomando de antemão uma verdade, a de que era preciso ter resistido a mais este ataque contra o povo judeu - verdade que surgia inabalável diante dos próprios relatos e do espetáculo criado -, não havia maneira de entender questões pertinentes que possibilitaram a ocorrência do terror. A violência mais terrível se pautava na destruição da identidade da vítima; como diz uma testemunha que fora prisioneira de um campo de concentração, os algozes sabiam "que o sistema que consegue destruir suas vítimas antes que elas subam ao cadafalso... é incomparavelmente melhor para manter todo um povo em escravidão. Em submissão". 96 A memória que vigorava no julgamento, a que era conduzida pelos acusadores, tornava-se bastante falha nesse tipo de situação: ao se apegar aos exemplos de bravura e resistência de alguns poucos, mesmo que tenham sido atos praticamente suicidas, propalava-se um heroísmo no qual somente alguns estavam em condições de se empenhar. Enquanto isso, não se conseguia ter a sensibilidade suficiente para compreender a situação daqueles que tiveram suas vidas destruídas antes mesmo de sofrer quaisquer agressões físicas. A coragem rememorada e propalada resultava não apenas em um difuso e infrutífero motivo de orgulho, mas também em demérito das vítimas que, supostamente, não teriam reagido e, dessa maneira, seguido submissas para a própria morte. Quem, afinal, estava sendo julgado? ${ }^{97}$

\footnotetext{
${ }^{96}$ Hannah Arendt. Eichmann em Jerusalém: um relato sobre a banalidade do mal. Tradução de José Rubens Siqueira. São Paulo: Companhia das Letras, 1999, p. 22.

${ }^{97}$ Como diz Celso Lafer, em um comentário que permite vislumbrar os perigos do desequilíbrio entre história e memória: "Hannah Arendt critica a posição da promotoria apontando que esta, vendo no indiciado o agente e o executor de uma lei geral - o ódio aos judeus no correr da História - fundamentou a acusação no que 'os judeus sofreram, não sobre o que Eichmann fizera'. Ela insiste, no epílogo do livro, em que uma postura desta natureza, calcada no conceito de crimes contra o povo judeu, leva a um equívoco básico: o de ver precedente num crime sem precedente. Este equívoco, para Hannah Arendt, deriva de uma falta de foco frequente na historiografia judaica, que privilegia a memória genérica da perseguição aos judeus em detrimento da especificidade dos contextos históricos. Daí uma peculiar dissociação do mundo, que impede uma avaliação e um juízo adequado da ruptura totalitária, ainda que
} 
Em certos momentos, como relata a autora, havia no tribunal uma atmosfera, senão de "julgamento-espetáculo", de "reunião de massa". A acusação convocava testemunhas que tinham toda liberdade para falar; orador após orador, abordavam, em boa parte das vezes, assuntos da resistência, tais como o gueto de Varsóvia e ações semelhantes, casos que, objetivamente, "não tinham nenhuma relação com os crimes do acusado". Por um lado, nessa sequência de relatos, há uma evidente necessidade de tornar as histórias conhecidas, de dar voz a todos aqueles que sofreram violências absurdas; quem seria capaz, "humanamente falando, de negar a qualquer dessas pessoas seu dia na corte?" Por outro, era uma instrumentalização dos testemunhos, posto que, conforme alerta Arendt, o governo de Israel tinha claro interesse em atrelar a resistência ao nazismo à atuação dos sionistas, como se fossem estes os que, quando não podiam mais salvar suas vidas, se sacrificavam pela honra do povo. Esta é uma situação limite, que torna ainda mais complicada a valorização de uma resistência idealizada; há, nisso, uma operação com o passado e, às vezes, uma terrível distorção, uma perda de foco, uma produção de culpas e esquecimentos. Como afirma a autora, "sob esse aspecto, talvez até mais significativamente do que sob outros, a tentativa deliberada de contar apenas o lado judeu da história no julgamento distorcia a verdade, até mesmo a verdade judaica". 98

Hannah Arendt, indo na direção contrária à da verdade pré-estabelecida, negou as distorções e reuniu coragem para lançar perguntas que não foram feitas no tribunal. Foi ousada a ponto de compreender como a questão "por que você não se rebelou?", feita a muitas das testemunhas, no fundo era uma pergunta irrespondível, uma "cortina de fumaça” e, não obstante, uma crueldade. Diante daquilo que se via no julgamento, da tentativa de vingar o passado e formular justificativas políticas para o contexto atual, a filósofa, em seu relato, bloqueia o espetáculo, inverte a lógica, pensa criticamente a história e põe o dedo na ferida que estava ficando esquecida - é possível dizer,

uma postura com estas características, provocada pela auto-referibilidade da catástrofe, possa ser compreensível nos planos sociológico e psicológico". Mais adiante, complementa: "Hannah Arendt critica a promotoria por querer subsumir o Caso Eichmann na memória genérica do antissemitismo, uma posição facilitada pela lei israelense, que previa crimes contra o povo judeu [...]. Esta crítica tem como objetivo mostrar que, desta maneira, não se esclarece o que foi o genocídio perpetrado pelos nazistas, ou seja, como diz Hannah Arendt, "um crime contra a humanidade, perpetrado no corpo do povo judeu"'. Celso Lafer. A reconstrução dos direitos humanos: um diálogo com o pensamento de Hannah Arendt. São Paulo: Companhia das Letras, pp. 175-177.

${ }^{98}$ Hannah Arendt. Eichmann em Jerusalém. Op. cit., p. 23 e p. 137. 
retomando o que foi dito a pouco, que ela estabelece o justo equilíbrio entre a história e a memória.

Há, portanto, em tudo o que envolve o julgamento, a dificuldade de se conseguir encontrar uma medida adequada na relação com o passado, um foco que não esteja encoberto pela projeção das sombras das perseguições antissemitas, pelo terror dos relatos e testemunhos, pela vontade de vingança, pela condenação das atitudes pessoais, pela inconsequente valorização de certos eventos. Além disso, a fala modelar de Eichmann, pautada em clichês e termos oficiais, revela as características mais perniciosas que a memória pode assumir: o bloqueio em relação ao outro, a negação da alteridade, o relato ensimesmado e a incapacidade de entender as consequências dos atos - daí se pode compreender, como diz Celso Lafer, que o entendimento de Hannah Arendt sobre o julgamento se baseia em uma concepção de "mundo centrífugo", que só existe pela pluralidade, diversidade e esperança; se pode entender, também, que o que deveria estar em julgamento neste tribunal, antes de qualquer coisa, era o genocídio enquanto "crime contra a humanidade perpetrado no corpo do povo judeu".99

No final do relato, contudo, a memória - novamente se revelando polissêmica surge aos olhos e ouvidos de Hannah Arendt como elemento imprescindível; desta vez, não como fator de confusão, mas como revelador da importância de dar vazão a certos relatos. Em meio a inúmeras falas de testemunhas, muitas das quais abordando assuntos que nada tinham a ver com o julgamento ou proferidas por pessoas extremamente traumatizadas, a autora consegue captar testemunhos de sofrimento que não poderiam restar no silêncio, falas que, apesar de curtas e feitas sem excessos, expunham dramas profundos. Surge, assim, uma consideração essencial: todos os relatos são importantes, mas é preciso encontrar a forma de transmiti-los, a maneira de narrá-los. Nesse sentido, "logo se descobriu, nas sessões intermináveis que se seguiram, como era difícil contar uma história, como - pelo menos fora do reino transformador da poesia - era necessário ter uma pureza de alma, uma irrefletida inocência de coração e mente que só os justos possuíam". ${ }^{100}$ Tal comentário permite compreender que, no contexto de um “julgamento-espetáculo", que progressivamente se transformava em "reunião de massa", em deliberada utilização do passado, eram os relatos feitos com certa simplicidade - a experiência não exposta em termos apelativos - aqueles que permitiam

\footnotetext{
${ }^{99}$ Celso Lafer. A reconstrução dos direitos humanos. Op. cit., pp. 181-182.

${ }^{100}$ Hannah Arendt. Eichmann em Jerusalém. Op. cit, p. 251.
} 
evidenciar as tragédias de uma falência moral, que traziam à tona as perguntas mais incômodas. Além disso, ficava claro que, se, por um lado, era preciso entender a fala, por outro, era preciso problematizar o ouvinte do relato.

A certa altura dos eventos, quando crescia um sentimento negativo em relação aos alemães e se exacerbavam ódios revanchistas, era possível, de maneira quase imperceptível, pontuar momentos de lucidez, instantes nos quais uma testemunha relatava que, vivendo perdida em meio ao caos e sem esperanças, fora ajudada por um alemão. Assim, envolta pela raiva crescente, emergia uma memória que indicava o contrário, que nem todos os alemães eram nazistas, que nem todos desprezavam os judeus, que as generalizações são inócuas e espelham aquilo que, justamente, se quer negar. Que, apesar de tudo, era possível nutrir um sentimento de esperança - seria este um momento, então, no qual o equilíbrio entre história e memória fora finalmente estabelecido? Hannah Arendt escreve que, durante o relato de um judeu, que contava como sobrevivera devido ao auxílio de um sargento alemão, baixou o silêncio sobre o tribunal, como se se quisesse prestar uma homenagem ao exemplo do sargento. E nesse vislumbre de dois minutos,

que eram como uma explosão de luz em meio à impenetrável, insondável escuridão, um único pensamento se recortava claro, irrefutável, além de qualquer questão - como tudo seria tão absolutamente diferente nesse tribunal, em Israel, na Alemanha, em toda a Europa, e talvez em todos os países do mundo, se mais dessas histórias pudessem ser contadas. ${ }^{101}$

São relatos como estes, que sobreviveram à dominação totalitária e escaparam aos interesses de apropriação política, que não foram destruídos no passado e nem instrumentalizados no presente, aqueles que justificam a necessidade de ouvir os testemunhos, de dar vazão à memória. Do terror, tragédia, sofrimento e falência moral, emergiam narrativas que se recusavam a ser esquecidas, que negavam a "banalidade o mal". Com diz a autora, em passagem das mais belas do livro:

Os buracos do esquecimento não existem. Nada humano é tão perfeito, e simplesmente existem no mundo pessoas demais para que seja possível o esquecimento. Sempre sobra um homem para contar a história. Portanto, nada pode ser "praticamente inútil", pelo menos a longo prazo. Seria de grande utilidade prática para a Alemanha de hoje [meados dos anos 1960], não meramente para o seu prestígio no estrangeiro, mas para a sua condição interna tristemente confusa, se houvesse mais dessas histórias para contar. Pois a lição dessas histórias é simples e está ao alcance de todo mundo. Politicamente falando, a lição é que em condições de terror, a maioria das pessoas se conformará, mas algumas pessoas não, da mesma forma que a

\footnotetext{
${ }^{101}$ Hannah Arendt. Eichmann em Jerusalém. Op. cit, p. 253.
} 
lição dos países no qual a Solução Final foi proposta é que ela "poderia acontecer" na maioria dos lugares, mas não aconteceu em todos os lugares. Humanamente falando, não é preciso nada mais, e nada mais pode ser pedido dentro dos limites do razoável, para que este planeta continue sendo um lugar próprio para a vida humana. ${ }^{102}$

Somente a memória tomada a contrapelo, no sentido benjaminiano da palavra, permite entender que não existem os "buracos do esquecimento". Essa é, possivelmente, uma das lições mais marcantes desse livro: existem memórias diversas, mas é preciso pensar suas narrativas e saber ouvi-las a fim de encontrar sinais de esperança. Quem entende a contrapelo deve ter a vontade do equilíbrio, compreender a medida da memória e do esquecimento, saber ouvir e balancear, escapar de verdades estabelecidas de antemão e procurar sempre por alternativas. No caso do julgamento, tais atitudes evitariam ódios generalistas e crueldades para com as vítimas. Da mesma forma, podese perguntar: não chegou a hora de saber ouvir e filtrar os excessos que circundam eventos como o nazismo, pelo menos o nazismo que é superdifundido e abordado de qualquer maneira? Como disse Hannah Arendt, o nazismo pertence ao "passado indomado"; os relatos, memórias e história que dele surgem não podem ser todos bem pensados. Hoje, décadas após a tragédia, basta ir a bancas de jornal ou livrarias para constatar o fenômeno: o nazismo está em toda parte, passou a ser, antes de uma falência moral e um crime terrível, uma espécie de curiosidade histórica. Em meio a essa profusão de informações e subinformações, quantos testemunhos não se perdem, quantas reflexões críticas ficam por fazer, quantos buracos de esquecimento não se acabam tentando cavar? Daí a necessidade de começar a pensar a redução ao invés da abundância, a aridez voluntária em lugar do afogamento na memória informativa; ou, como diz Beatriz Sarlo, retomando algumas palavras de Primo Levi (ele próprio, um exprisioneiro de Auschwitz): "nunca, diz Levi, um testemunho verdadeiro deve abrir a possibilidade para que um testemunho exagerado tome seu lugar". ${ }^{103} \mathrm{O}$ mesmo não acontece, por exemplo, com as ditaduras militares latino-americanas? A romantização do passado, a vitimização ou a heroicização, assim como a consequente fragilidade do debate, não deixam relegados ao esquecimento os relatos de muitos sofrimentos, não tornam impunes muitos dos crimes do terrorismo de Estado? Quando a história passa a ser entendida como anedotário ou como mera idealização do passado, não se está ratificando um culto empobrecedor da memória? Há, aqui, uma nota de aparente

\footnotetext{
${ }^{102}$ Hannah Arendt. Eichmann em Jerusalém. Op. cit, p. 254.

${ }^{103}$ Beatriz Sarlo. Tempo passado. Op. cit, p. 34.
} 
paradoxo, pois pensar o esquecimento é qualificar a própria memória, é torná-la crítica, menos revanchista e mais propositiva; é fomentar a justiça, e não simplesmente dar vazão a rancores, ódios e, pior, oportunismos. É não somente imputar culpas, mas, acima de tudo, cobrar responsabilidades. Dessa maneira, a memória, em busca do equilíbrio e permeada pelo esquecimento crítico, abre novas perspectivas; segue um sentido diverso e positivo, ao invés de se fechar sobre si mesma. Acerca de d. Pedro II, o excesso memorialístico que o envolve e se renova constantemente não esteriliza a reflexão e o entendimento histórico, não o torna cada vez mais uma "superpessoa" da memória? Esquecer, pois o esquecimento também é polissêmico, pode se tornar uma renovada forma de entendimento e pensamento, uma maneira de problematizar a memória; uma maneira, principalmente, de superar uma memória fácil, abusiva, apelativa e segmentária. Ou, como afirma Beatriz Sarlo - inspirada em uma reflexão de Susan Sontag, qual seja: "talvez se atribua valor demais à memória e valor insuficiente ao pensamento" -, "é mais importante entender do que lembrar, embora para entender também seja preciso lembrar". ${ }^{104}$ Afinal, se a política não é nenhum jardim de infância, como diz Hannah Arendt na sentença que teria proferido a Adolf Eichmann caso tivesse tido a oportunidade de o fazer, a memória, pelo fato de que não se deve lembrar sem entender, também não o é.

\footnotetext{
${ }^{104}$ Beatriz Sarlo. Tempo passado. Op. cit, p. 22. Para dar profundidade a essas ideias, lembre-se das palavras de Renato Janine Ribeiro: "Toda identificação excessiva a si mesmo supõe, enfim, uma identificação quase insuportável das dores, uma disposição a não esquecer nada; e penso que seria mais que tempo de substituir aquela frase cruel - 'posso perdoar, mas não esquecer' - por outra, quase cômica, porque expressa uma impossibilidade - 'posso esquecer, mas não perdoar'. Porque, se esqueço, nem tenho mais como, ou por que, ou para que perdoar... Só o esquecimento, de fato, põe fim à dor; ou então, melhor ainda, o riso". Renato Janine Ribeiro. "Grandeza e miséria do "politicamente correto"'. In: $A$ sociedade contra o social. Op. cit, pp. 43-44. Em outro momento, diz ainda o filósofo: "O desejo de vingança é um anseio de desfazer o que aconteceu de mau, e de retomar a um passado miticamente bom. Punindo quem nos feriu, ele reequilibra o que foi perturbado na balança das coisas e restaura uma ordem que pensamos recordar, mas que, na verdade, fantasiamos. Já a busca da justiça está voltada para o futuro. Ela exige, pois, que esqueçamos. Não há justiça sem esquecimento. Esquecimento quer dizer também anistia. Não há justiça sem algum grau de perdão pelo passado, porque o que ela busca é construir um tempo futuro. Por isso todo anseio de justiça tem algo de utópico, na medida em que sua matéria-prima, seu terreno de intervenção, é o mais feito de imprevistos, o tempo por vir. Isso significa, finalmente, um certo paradoxo. Para haver justiça - no futuro - é preciso perdoar o passado: ou seja, a justiça jamais é simples retribuição exata do que aconteceu. Por isso é que a lei de Talião, ou retaliação, produz injustiça. Porque, ainda que pareça, a curto prazo, reequilibrar a perturbação que o crime cometeu, punindo-o na medida adequada, ela esquece que a justiça não está na restauração de um equilíbrio sempre mítico, mas na produção de um futuro que tenda, mesmo nunca o realizando, a algum equilíbrio. Insisto no termo 'produção', que é o que permite entender que algo somente surja porque entre de tudo na sua composição: entre, inclusive, o que do passado ficou de injusto, e que perdoamos, para evitar maior injustiça no futuro". Renato Janine Ribeiro. "O Brasil pela novela”. In: A sociedade contra o social. Op. cit, pp. 139140.
} 


\section{SEGUNDA PARTE}

\section{Flores para o rei}




\title{
CAPÍTULO 3
}

\section{A memória de d. Pedro II, um espectro ronda a República}

\author{
Tu, cuja vida vivifica os germens \\ Da glória nacional que Te circunda; \\ Defensor do Brasil, Tu que, instruído \\ Dos deveres de Rei, sabes que o trono, \\ Barreira de paixões desordenadas, \\ $\mathrm{O}$ apoio deve ser da liberdade, \\ Da justiça e da paz, e o altar sagrado, \\ Cujo fogo perene animar deve \\ Ciências, letras, artes e virtudes; \\ Monarca Brasileiro, aceita o canto \\ Que te dedica o vate agradecido; \\ E faze que outros muitos mais ditosos, \\ Porém não mais da nossa terra amigos, \\ Eterna glória deem a Ti e à Pátria.
}

Gonçalves de Magalhães, em 1856, na última estrofe de $A$ Confederação dos Tamoios

A República tratou da memória imperial, de maneira mais incisiva e com maior pragmatismo, quando, no começo da década de 1920, permitiu novamente a entrada de membros da família imperial no Brasil, assim como, evento principal, o translado para o país dos restos mortais d. Pedro II e Da. Teresa Cristina (1822-1889). Desde antes da morte do imperador, ocorrida em 5 de dezembro de 1891, o Instituto Histórico e Geográfico Brasileiro (IHGB), órgão fundado em 1838 e que sempre lhe fora fiel, se encarregara da missão de preservar e exaltar sua memória. Como diz Lilia Schwarcz, estavam sendo dados, já bem cedo, "os primeiros passos em direção ao 'culto da memória do imperador', a sua 'consagração póstuma"”; o imperador seria, dessa maneira, "recuperado não por sua face de governante, mas como um rei místico e sagrado". ${ }^{105}$ Um monarca, portanto, sábio e imparcial, governante sem paralelo, moderno e apolítico. Essa indistinção, esse arranjo entre aspectos de esferas diferentes, é isso, talvez, o que caracteriza o resgate de d. Pedro II, o que acaba por lhe dar imenso efeito político.

A campanha, propriamente dita, pelo retorno dos despojos de Pedro II fora iniciada já em 1892; contudo, nos primeiros momentos da República, essa era uma questão espinhosa, deixava nítidas as dificuldades do novo regime em operar com o passado monárquico. Constantemente prorrogada, anos a fio arrastou-se o dilema, até

\footnotetext{
${ }^{105}$ Lilia M. Schwarcz. As barbas do imperador. Op. cit, p. 496.
} 
ser tratado, em 1916, pelo então presidente Venceslau Brás (1868-1966), como assunto a ser decidido "para a ocasião do centenário da independência" 106 - deixar, portanto, as questões do passado para os anos festivos, para os momentos de sagração da memória. Cabe, neste ponto, uma pergunta: qual era a real necessidade, para o regime republicano, de trazer os despojos para o Brasil? A resposta pode estar no contexto celebratório e no culto do passado, o que era feito a serviço do presente e com vistas no futuro. Logo no início da década de 1920, constituía-se um novo marco para a memória nacional: o centenário da independência do Brasil. Era preciso, então, forjar heróis, tradições, símbolos, cerimônias pátrias e museus históricos. D. Pedro II, certamente, ocupava papel de destaque nessa equação memorialística, pois exercera função chave na formação do Estado nacional; o culto de sua memória, se bem ritualizado, poderia fomentar uma celebração positivada, constituir suporte de idealizações, indicar uma via para tangenciar polêmicas. A presença de evidências físicas era o argumento inalcançável, efetivo fetiche pelo passado; diante do apelo da prova material, era difícil encontrar meios de refutar a versão oficial dos fatos. Era uma maneira, por assim dizer, de tentar controlar as evidências, enterrar o passado, lançar a pá de cal definitiva.

O grande problema, contudo, é que, além de festividades e celebrações, as comemorações pelos cem anos de autonomia política, invariavelmente, exigiam uma reinterpretação da história nacional; como afirma o historiador Francisco Iglésias (19231999), "as grandes datas impõem balanços e projetos". Pautado no conceito de "geração" - formulado pelo filósofo espanhol Ortega y Gasset (1883-1955) - Iglésias argumenta que o centenário da Independência foi um evento histórico capaz de instigar a crítica política e cultural em setores desprestigiados da Primeira República, assim como nos dissidentes das elites oligárquicas. Cem anos depois da liberdade política, era possível perguntar se era esse realmente o país que se queria, se era aceitável o que dele se tinha feito. ${ }^{107}$ Nesse sentido, até mesmo para os críticos, o problema do retorno se

\footnotetext{
${ }^{106}$ Lilia M. Schwarcz. As barbas do imperador. Op. cit, p. 499.

${ }^{107}$ Francisco Iglésias. História e Literatura. São Paulo: Perspectiva; Belo horizonte: Cedeplar-FACEUFMG, 2009 (Estudos: 269), pp. 247-249. Sobre esse assunto, atentar também para as palavras de Angela de Castro Gomes: "Comemorações como essa [o Centenário da Independência] costumam mobilizar os governantes e a sociedade em geral, pois são sempre uma oportunidade e um convite especiais à realização de balanços, quer com objetivos de engrandecimento, quer com explícita intenção crítica. Por isso, políticos e intelectuais estão particularmente nelas envolvidos, uma vez que têm como atribuição específica a produção de análises que permitam a compreensão da realidade do país, com base nas quais serão construídos projetos visando seu maior progresso. Em síntese, explicações sobre as causas do 'atraso' e ideias sobre as possibilidades de 'modernização"”. Angela de Castro Gomes. "A política brasileira em busca da modernidade: na fronteira entre o público e o privado". In: Fernando A. Novais
} 
impunha: dependendo da maneira com que conduzisse o assunto, a prova física podia ser motivo, ao invés de culto, de questionamentos e expressão de descontentamentos se o imperador, lembrando aqui das palavras de Pierre Nora, enquanto um elemento de memória, podia ser, para o bem ou para o mal, retomado quase como um signo em estado puro, a presença do significante (no caso, os próprios restos mortais) passava a ser um assunto de grande importância. Parafraseando a socióloga e crítica literária argentina Beatriz Sarlo, é possível dizer que "os mitos (distintos) que se alimentavam" de d. Pedro II "precisavam ver esse corpo como uma dimensão fundamental: suas qualidades não esgotavam nenhum mito, mas sustentavam todos". 108

Chamo a atenção, neste sentido, para um ponto interessante: a argumentação original de Beatriz Sarlo fala de Eva Perón (1919-1952), e não do monarca brasileiro. São dois casos distintos, épocas e cenários diferentes, mas ambos marcados pelo espectro de mitos políticos que surgem, se alimentam e se erigem a partir de corpos corpos que, mesmo depois de mortos, seguem bastante vivos e atuantes na vida política. Algumas palavras da socióloga, quando fala a respeito da primeira-dama argentina, podem servir de referência para se pensar e indagar acerca do caso de d. Pedro. Por exemplo: “o seu [de Eva Perón] caráter excepcional é um efeito do 'fora do lugar', que prefere silenciar o óbvio (o fato de que ela vinha de fora da classe, do sistema), e suas qualidades, insuficientes num cenário (o artístico), tornavam-se excepcionais em outro cenário (o político)" ${ }^{109}$ D. Pedro II, de alguma forma, também fora marcado por certo deslocamento: seu tão propalado descontentamento com a posição de imperador, com as obrigações de sua condição, com os enfadonhos compromissos monárquicos; sua sempre lembrada vontade de ser professor ou senador e viajar livremente pelo mundo. Percebe-se, em tudo o que envolve sua memória, essa relação entre insuficiência e excepcionalidade, notas de negação e sacrifício. Cria-se uma situação que alimenta incertezas e ambiguidades (e lembre-se, aqui, da frase elaborada por Paulo Mendes Campos e que poderia ter sido dita pelo imperador): para alguns, era um monarca insuficiente, mas um sábio excepcional; para outros, um sábio insuficiente, mas um

(coord.) e Lília M. Schwarcz (org.). História da vida privada no Brasil: contrastes da intimidade contemporânea. Op. cit., p. 492.

${ }^{108}$ Beatriz Sarlo. A paixão e a exceção: Borges, Eva Perón, Montoneros. Tradução de Rosa Freire d'Aguiar, Heloisa Jahn, José Marcos Macedo, Rubia Prates Goldoni e Sérgio Molina. São Paulo: Companhia das Letras; Belo Horizonte: Editora UFMG, 2005, p. 21.

${ }^{109}$ Beatriz Sarlo. A paixão e a exceção. Op. cit., p. 24. 
político bastante sagaz; para outros, ainda, não era nenhuma das duas coisas, ou, até mesmo, as duas ao mesmo tempo. ${ }^{110}$

Curiosamente, note-se que Beatriz Sarlo vai usar a ideia dos dois corpos do rei, estudada por E. H. Kantorowicz, para falar em “dois corpos de Eva”. A um só tempo, conseguia ser corpo natural e corpo político: Virgem e mulher, moça simples e esposa do presidente, humildade em pessoa e personalização do regime, sensibilidade e poder. $\mathrm{Na}$ fusão dessas diferentes densidades, reside sua força e sua excepcionalidade; logo, "seu corpo material é indissolúvel de seu corpo político". No caso de Eva, argumenta Sarlo, foi o corpo material que produziu o corpo político e, a partir de certo momento, um não se sustentava mais sem o outro. Ou seja, foi seu estilo, sua beleza, sua agonia e, por fim, seu espantoso drama físico, que alimentaram o mito, que criaram meios de identificação e encantamento com a população. Era a materialidade humana, enquanto uma estrutura ímpar de sustentação, que a fazia - "a esbeltez e depois a doença pesam em favor de seu estilo e diferença" -, atriz de cinema, irmã de caridade, fada madrinha,

${ }^{110}$ Sobre o deslocamento de $d$. Pedro II, um dos autores que mais insistiu sobre esse tema foi Gilberto Freyre. O imperador, na interpretação de Freyre, não foi o arquipatriarca que deveria comandar a nação e mantê-la ligada às suas origens históricas e culturais. Teria sido, por outro lado, - tal como escreveu em sua tese de mestrado, realizada em 1922 -, antes de qualquer coisa, "uma espécie de Rainha Vitória de calças - apenas mais poderosa que a austera rainha inglesa - que fiscalizava os estadistas à maneira de um agente e até de um detetive de polícia: polícia moral. Polícia de costumes. É demais conhecido que ele recusava indicar homens públicos para posições de destaque no país e no estrangeiro por causa de irregularidades na vida privada - tradição que os líderes republicanos achariam caturrice conservar" (Vida social no Brasil nos meados do século XIX. São Paulo: Global, 2008, p. 85). Em 1925 (entre, vale ressaltar, a realização da Semana Regionalista de 1924 e a publicação do Manifesto Regionalista de 1926), na Biblioteca Pública de Recife - pois não haveria lugar mais apropriado, segundo o palestrante, para falar de um adorador dos livros -, Freyre proferiu um sugestivo discurso em homenagem ao centenário do imperador: "Dom Pedro II, imperador cinzento de uma terra de sol tropical". Nele dizia que, apesar de suas inúmeras qualidades, conhecimentos e retidão de caráter, o monarca não fora $o$ governante que o Brasil do século XIX precisava, pois "faltou-lhe o ânimo, faltaram-lhe as qualidades pessoais para ser o que a tradição do Brasil patriarcal, a necessidade do momento e o próprio futuro brasileiro pediam que ele fosse: um coordenador das divergências necessárias”. D. Pedro II teria sido, "em desacordo com o meio e as tradições de nosso país, uma figura de burguês liberal feito para governar a Suíça". Viria daí seu aspecto trágico, esse desacordo com o mundo que o envolvia; para comandar um país de senhores escravocratas, era preciso alguém que lhes entendesse, fosse rigoroso no comando e coordenasse as "divergências necessárias". Não era, portanto, o momento adequado para liberalismos acadêmicos desenraizados da cultura brasileira, de "pacifismo mórbido" e de "sacrifício das divergências saudáveis de que ele deveria ser coordenador e nunca o destruidor" ("Dom Pedro II, imperador cinzento de uma terra de sol tropical". In: Perfil de Euclides e outros perfis. Rio de Janeiro: Record, 1987, pp. 130 e 131). Nessa visão, o monarca teria sido sempre um brasileiro meio deslocado, tentado demais por teorias inócuas e pelo pathos da modernidade, incapaz de compreender a importância de conservar os laços com o passado. Seu reinado, como diria o sociólogo em Sobrados e mucambos, teria sido, em grande parte, "antipatriarcal"; o imperador "temia pouco os oligarcas das casas-grandes do Império", porque "temia mais a opinião dos europeus a seu repeito". Essa postura se concretizava em uma "valorização do moço de vinte anos", uma proposta de renovação da ordem social e jurídica que se faria alijando do poder "os grandes interesses do patriarcado agrário, às vezes turbulento e separatista, antinacional e antijurídico". Era, em outras palavras, "o começo daquilo a que Joaquim Nabuco chamou de neocracia", "a transcrição do patriarcalismo para o individualismo" (Sobrados e Mucambos. São Paulo: Global, 2004, pp. 433-434). 
princesa plebeia, mártir da nação, todas essas mulheres ao mesmo tempo. Ao longo de sua obra, Beatriz Sarlo escrutina a construção desse mito, desde a elegância e as vestes, consagradas no "traje público", um (e seria isso uma contradição?) uniforme especialíssimo - o tailleur modelo príncipe de Gales -, até a apresentação do corpo, penteado, iconografia, propaganda, representação pública. Eva tinha, segundo a autora, um corpo político e alegórico, um físico que foi trabalhado, moldado e vestido; foi, em suma, estrategicamente planejado e testado junto à população. Sem excessos, era um suporte que, por não ser artístico nem inexpressivo demais, nem sensual nem comum, foi aceito pela grande maioria e se adequou tão bem à tarefa de ser um negócio de Estado.

Após a morte dessa personagem marcante, ocorrida em julho de 1952, quando contava fatídicos 33 anos, depois do sofrimento imputado pelo câncer ter se tornado espetáculo nacional, inúmeras homenagens ganharam os espaços públicos celebrações, ressalte-se, “cuja magnitude só foi comparável ao enterro de um monarca ou à pomposa cenografia fúnebre dos líderes totalitários". ${ }^{111} \mathrm{O}$ seu corpo, na expectativa de eternizá-lo enquanto instrumento político, foi embalsamado - seria, talvez, uma tentativa, por parte do regime peronista, através da fusão de corpo político e corpo natural em um só, de controlar a difusão do signo pelo domínio do significante? Dessa maneira, estava consolidado, ou assim se imaginava e queria, uma referência por cujo raio teria de passar a vida política argentina, um expoente que filtrava e enfeixava todos os debates; "os restos materiais conservados no auge de sua beleza (que a morte transforma em sublime)", eram, em suma, "a representação de uma autoridade e de um tipo de regime". Contudo, mesmo "perfeito, com indelével perfeição do petrificado, o corpo de Eva, que continuava a ser duplo", era uma presença sufocante. Como não poderia deixar de ser, tornou-se alvo de adoração e ódio, um objeto de disputa; todos o desejavam para si. ${ }^{112}$ A partir dessa efetiva relíquia, emerge um turbilhão de eventos e conflitos, que vão desde o sequestro do corpo embalsamado, até ações dos Montoneros e impressionantes assassinatos políticos. Como bem atestado pela história e por uma intrigante literatura - obras de autores como Jorge Luis Borges, Rodolfo Walsh, Copi, Néstor Perlongher, Tomás Eloy Martínez ${ }^{113}$-, a tentativa de controlar o signo e unificar

\footnotetext{
${ }^{111}$ Beatriz Sarlo. A paixão e a exceção. Op. cit., p. 30, p. 72, p. 82, p. 90 e p. 94.

112 Beatriz Sarlo. A paixão e a exceção. Op. cit., p. 109.

113 Jorge Luis Borges. "O simulacro". Tradução de Joseny Vianna Baptista. In: Obras de Jorge Luis Borges. Volume 2. São Paulo: Globo, 1999, p. 186; Rodolfo Walsh. "Essa mulher". In: Essa mulher e
} 
o duplo, fora insuficiente; ao invés de abafar discórdias e superar o passado, a memória fora potencializada, tornara-se matriz de ações políticas e disputas no presente. Como comentado em capítulo anterior ao se falar do julgamento de Eichmann, a memória, quando se trata de um evento de confluências e repleto de significados, pode ser empregada de diferentes formas, dar margens a muitos entendimentos. Pode, enfim, se tornar incontrolável e excessiva.

Guardadas as devidas proporções, é possível perguntar: com d. Pedro II - que, enquanto monarca, já era em si um duplo fundamental - não aconteceu, notadamente após o exílio, algo semelhante ao que ocorreria com Eva Perón? O martírio do corpo físico não foi matriz de mitos políticos? A República teve de conviver com um espectro, contornar o pesar causado pela morte do imperador, figura comovente: senhor de idade, aparência de ancião, abatido, viúvo, solitário, vivendo longe de casa, longas barbas brancas e com recursos parcos. Um convite ao desequilíbrio entre história e memória, o apelo ao espetáculo em detrimento da crítica; como diz Joaquim Nabuco (1849-1910), em uma de suas observações de síntese e efeito: "decerto o exílio do Imperador foi triste, mas também foi o que deu à sua figura a majestade que hoje a reveste". ${ }^{114}$ Em outras palavras, boa parcela do culto do monarca, como deixa perceber parte da documentação, se nutriu de um difuso sentimento de culpa. Mais ainda, como bem comenta Lilia Schwarcz, na esteira da vergonha, "morre o homem e nasce o mito, nesse movimento que vai transformando a história numa boa metáfora". ${ }^{115}$ Exemplo notório disso é o livro, já comentado anteriormente, de Luís Martins, O patriarca e o bacharel, em que o autor faz estudo de certo "complexo de remorso" manifestado por alguns republicanos que tinham derrubado Pedro II do trono. Apoiado em teses psicanalíticas e documentação histórica particular (o álbum, no qual amigos assinavam e deixavam recados, de José Pinto do Carmo Cintra, iniciado em 1869), Martins aponta como

a geração dos bacharéis românticos fez a República, assimilando a figura hostilizada do Pai, até então encarnada na do potentado rural, à do imperador

outros contos. Tradução de Sérgio Molina e Rubia Prates Goldoni. São Paulo: Editora 34, 2010, pp. 1829; Copi. Eva Perón. Traducción de Jorge Monteleone. Buenos Aires: Adriana Hidalgo Editora, 2000; Néstor Perlongher. "Evita vive". In: Evita vive e outras prosas. Tradução de Joseny Vianna Baptista. São Paulo: Iluminuras, 2001, pp. 23-28; Tomás Eloy Martínez. Santa Evita. Tradução de Sérgio Molina. São Paulo: Companhia das Letras, 1996.

114 Joaquim Nabuco. Minha formação. Apresentação de Alfredo Bosi. São Paulo: Editora 34, 2012, p. 216.

${ }^{115}$ Lilia M. Schwarcz. As barbas do imperador. Op. cit., p. 493. 
D. Pedro II, que passou a simbolizar, mais do que nunca (já era, pela situação de rei, um símbolo natural de paternidade), a entidade paterna. ${ }^{116}$

Em suma, segundo o autor, havia algo de "complexo de Édipo" no Quinze de novembro, o que era devido a uma "consciência patriarcal" que medrava no Brasil a partir das estruturas de poder legadas pelos tempos coloniais:

sem a estrutura da colônia, que fez do pater-familias um senhor quase absoluto em seus domínios rurais, o complexo de Édipo teria tido, em seus filhos, uma projeção normal. Não criaria aquela hostilidade aguda, que apenas se saciaria num ato de violência ${ }^{117}$.

A ação dos jovens e entusiasmados republicanos fora, dessa forma, desmedida e fruto de revolta filial. A lógica da família, referenciada na ideia de pessoa e no segmento, torna-se determinante para o mundo público. O resultado é que a república alcançada, decorrência de ação juvenil, virava motivo de frustração, não era aquela com a qual se tinha sonhado; restava, então, somente o remorso de quem vê um pai envelhecido e fraco fenecer longe de casa, num reles, e sempre impessoal, quarto de hotel. Era o arrependimento e a nostalgia, transbordantes, de quem cometera terrível injustiça contra o monarca bondoso, que tanto amara seu país e sua gente. O porte físico, a barba branca, o sofrimento, o abandono, as lágrimas escondidas quando da viuvez, a gangrena no pé esquerdo, o fim da existência em meio a livros, tudo isso criava certa aura, um imaginário que o envolvia e o tornava uma presença sufocante. No entanto, à diferença da primeira-dama argentina, não fora o Estado - ao menos não no primeiro momento -, quem moldara esse corpo; a triste figura imperial, antes e depois da morte, era usada para insuflar as críticas ao regime de Quinze de novembro. Virara um peso na consciência da República, uma culpa persistente. A volta dos restos mortais, no contexto do centenário da independência, evidencia a necessidade, por parte do regime republicano, de se redimir, fazer justiça ao passado e torná-lo passível de novas apropriações. De renegado, d. Pedro II passaria a herói. Estamos, assim, tratando de corpos capturados por ideias; corpos tornados fontes de interpretações e, consequentemente, objetos de disputa. Entende-se, então, a importância de ter o controle sobre a materialidade dos despojos; é preciso criar um sustentáculo para a memória, uma referência que a torne espetáculo e recurso político. Dessa maneira, pode-se dizer que Pedro II retornava a sua terra natal para se tornar um efetivo, na expressão de Pierre Nora, lugar de memória.

\footnotetext{
${ }^{116}$ Luís Martins. O patriarca e o bacharel. Op. cit., p. 27/28.

${ }^{117}$ Luís Martins. O patriarca e o bacharel. Op. cit., p. 158.
} 
O tema do fim do banimento e do retorno dos despojos, como é possível imaginar, ganhou grande publicidade; surgiram, na imprensa, artigos que tratavam da volta do imperador; aos poucos, uma campanha foi ganhando corpo. Em maio de 1920, cerca de um ano antes da morte da princesa Isabel (1846-1921), um jovem José Lins do Rego (1901-1957) apelava, nas páginas da revista recifense Vida Moderna, em favor dos exilados; carregando nas tintas do sentimentalismo, opondo a modorrenta Isabel ao regime impiedoso, o escritor emendava:

Isabel no seu desterro, com os seus olhos azuis cristalizando lágrimas, quando lhe fogem os filhos amados, outra vez estende seus braços imaculados para a terra ingrata. Quer o Brasil, o seu sol cruel, o seu céu estrelado, a sua paisagem bonita...

E o Brasil nega-se. Ele que tem em seu solo fecundo estadistas estrábicos e governantes espertos, mil vezes mais perigosos do que Isabel - a boa.

No seu rico e monótono castelo de França, Isabel, com a alma bipartida, chorou mais um pranto de mágoa. ${ }^{118}$

O artigo de José Lins do Rego cria um cenário impressionista, no qual Isabel representa toda pureza, desde os olhos azuis cristalizando lágrimas, até a morte dos filhos e o apelo saudosista pela terra natal, enquanto o Estado brasileiro é a crueldade encarnada; até mesmo o elemento natural da paisagem, o sol escaldante, é reafirmado pelos políticos insensíveis e perigosos. Fica bem claro, nesse jogo de opostos, qual o foco do jovem escritor: a referência à princesa vai dando contornos às críticas aos políticos de então.

Pouco tempo depois, cerca de um mês, em junho de 1920, um não menos jovem Sérgio Buarque de Holanda - e, como se verá, não menos entusiasta e exaltado pelas palavras -, aparecia na revista $A$ cigarra, publicação paulista, com um texto distante do rigor interpretativo dos anos futuros. Trata-se, nesse momento, de um rapaz enredado pelo mito do imperador e pelo olhar crítico lançado à Primeira República; a erudição e a capacidade analítica, porém, já estão bem nuançadas. No breve artigo, antes do apelo final pelo retorno, vem traçado um sucinto histórico da carreira política do imperador: Pedro de Alcântara subiu ao poder em cenário de incertezas, quando o Império atingira o ápice de seu "momento psicológico"; hora, portanto, de decisões inadiáveis. Havia dúvidas sobre quem era o novo monarca, qual seu caráter, como seria seu governo; um

\footnotetext{
118 José Lins do Rego. "Princesa dolorosa". In: Ligeiros traços: escritos de juventude. Seleção, introdução e notas de César Braga-Pinto. Rio de Janeiro: José Olympio, 2007, pp. 80-81.
} 
"terrível ponto de interrogação" que ficou em suspenso por "três lustros" - do nascimento à Maioridade. Pouco após a coroação, porém, a grata confirmação das melhores expectativas: o príncipe identificara-se com a pátria, participava "de todas as suas vicissitudes e todas as suas glórias"; “deu-lhe o que de melhor podia dar, deu-lhe a liberdade". No Brasil de d. Pedro II, campeava a liberdade e "pompeava" o progresso; o imperador era amado, seu prêmio era a devoção do povo. No entanto, "como sói acontecer sempre, não tardou o aparecimento de invejosos que tomaram a peito fazer campanha contra o homem a quem o Brasil tudo devia"; consequência dessa efervescência de ódio, o imperador foi deposto e expulso do país que tanto amava. "Assim, aquele que merecera a admiração de Vitor Hugo, Pasteur, Lamartine, Alexandre Dumas, Gladstone e Darwin era vítima da ingratidão de seus compatriotas”. Segundo o articulista, era tempo de suspender as paixões políticas e fazer as merecidas homenagens. Percebe-se, nesse texto de juventude, uma admiração pelo progresso, pelo avanço moral e cultural: era gente de ponta (escritores, cientistas, políticos) quem admirava o imperador; logo, os limites da nossa maneira de fazer política - o que revela a força memorialística e a produtividade do arranjo enfeixado em d. Pedro II -, tão arbitrária e tendente a paixões, a esquecimentos e rememorações, ficavam nítidos, vergonhosos e revelados em seu atraso. Bondade e justiça eram virtudes que escapavam a essa prática mesquinha, mas não aos sábios das nações modernas. Nesse sentido, não podia haver glória nem reconhecimento maior que a volta do rei a sua pátria:

Não se justifica mais a permanência em terra estranha dos restos mortais daquele que em vida foi a encarnação perfeita da bondade e da justiça. É uma covardia infanda, a de temerem que os despojos de Dom Pedro II como os de sua augusta esposa possam abalar algo, a nossa atual forma de governo. Esquecem-se os ingratos de que foi sob sua augusta sombra, protegidos por sua clemência incomparável, que os propagandistas da república pregaram e implementaram o atual regime. Felizmente, o sr. Epitácio Pessoa teve a feliz lembrança de, na última mensagem apresentada ao Congresso Nacional, contemplar devidamente essa questão.

Se o entusiasmo de minhas dezessete primaveras ainda não poluídas pelo vírus das paixões políticas pudessem projetar ondas de luz e eloquência sobre estas palavras, eu ousaria pedir a S. Excia. que estendesse a sua magnanimidade fazendo revogar o decreto, já sem razão de ser, do banimento da família imperial. ${ }^{19}$

São dois textos curtos, entusiasmados, dramáticos, nutridos de fervor juvenil; se são um tanto pueris em suas colocações e demasiado eloquentes na forma, não deixam

\footnotetext{
${ }^{119}$ Sérgio Buarque de Holanda. "Viva o Imperador". In: Sérgio Buarque de Holanda: escritos coligidos, livro I (1920-1949). Organização de Marcos Costa. São Paulo: Ed. UNESP; Fundação Perseu Abramo, 2011, pp. 3-7.
} 
de ser reveladores em seus objetivos. Perpassando o assunto do retorno e esbarrando no tema da culpa, o alvo das críticas recaía todo na República. Os políticos atuais seriam cruéis, invejosos, medrosos, estadistas estrábicos. Além do mais, lembre-se que aquele ano de 1920 era de celebração: se ainda vivo, o imperador, no começo de dezembro, completaria mais um lustro, 95 anos. O tema de seu retorno ao Brasil, então, era candente, pressionava a atualidade. Ficava sensível a necessidade de retomar temas do passado e problematizar as questões do presente. O dilema é que nesse assunto dos despojos do imperador, era o corpo da República aquele que, efetivamente, estava em debate. É preciso salientar mais um fato, uma questão interessante, que revela aspectos mais profundos desse dilema: José Lins do Rego fala de Isabel, e não sobre d. Pedro II; para o escritor paraibano, a princesa, por ser a redentora e católica, era quem merecia as homenagens e o direito de retornar, não seu pai. Isabel era a tradição, o Brasil profundo e religioso, enquanto Pedro II representara uma modernização difusa e artificial - Lins do Rego, ao contrário de Sérgio Buarque, não se preocupa, por exemplo, em listar nomes de sábios europeus a fim de elevar a memória do monarca. Ou seja, nesse cortejo de corpos, eram muitas as polêmicas que vinham a reboque; além disso, a ambiguidade do imperador, novamente, se revelava enquanto risco e produtividade. ${ }^{120}$

A Primeira Guerra Mundial (1914-1918), tornando perigosa a travessia atlântica e dificultando os contatos diplomáticos, impusera barreiras à continuidade do projeto de retorno. Apesar dos percalços, era consenso que o problema deveria ser resolvido antes de setembro de 1922; as comemorações do centenário da independência exigiam que um dos principais artífices do Estado brasileiro estivesse presente no país. Somente com o decreto número 4120, de setembro (o mês da pátria, portanto) de 1920, autorizou-se o retorno dos despojos mortais do imperador a sua terra natal, assim como ficou permitida

\footnotetext{
${ }^{120}$ A posição de José Lins do Rego em relação a d. Pedro II pode ser melhor notada em um texto escrito no ano de 1924, "Carta de uma geração aos srs. Gilberto Freyre e Jackson de Figueiredo". Nesta carta, ao falar sobre a proclamação da República, Lins do Rego faz estes emblemáticos comentários: "A obra [a proclamação do novo regime], em si, não reclama grandes artistas, mas a parte do Exército para esta república fora meramente material. O romantismo democrático e os negros libertos, a grosso, pela princesa Isabel, valeram muito mais que a parada militar de 15 de novembro. O próprio imperador só faltou sair do S. Cristóvão de vermelha, à Garibaldi, e dar seu grito à República. $\mathrm{O}$ mais, tudo fez ou consentiu que fizessem, para que não se partisse seu ar ingênuo de apóstolo de solidariedade humana". In: Ligeiros traços: escritos da juventude. Op. cit., p. 277. Outro caso emblemático: a prisão dos bispos de Olinda, d. Vital Maria de Oliveira, e do bispo do Pará, d. Antônio de Macedo Costa, em 1874. Enquanto o imperador é tratado como responsável por colocá-los no cárcere, a princesa Isabel, na pena do autor, não deixou de apoiá-los, indo, inclusive, à cadeia para fazer visitas. Esse é o tipo de caso que, aos olhos de José Lins do Rego, diferenciava profundamente os dois personagens.
} 
a entrada de seus familiares no Brasil ${ }^{121}$ - atendidos, assim, os apelos dos jovens José Lins do Rego e Sérgio Buarque de Holanda. O regime republicano, com isso, dava um passo tão largo quanto incerto: ia-se reintroduzir na vida nacional um elemento que fora banido; era uma atitude de atribuladas implicações políticas e simbólicas, pois se tratava de uma revisão de antigas posições. O banimento da família imperial, se fora uma necessidade pragmática em 1889, teve de ser seguido por uma série de ações que visavam marcar uma ruptura de regime político e dissolver o passado mais recente. Uma prática, nesse sentido, foi o leilão dos bens imperiais; sobre isso, Regina Abreu comenta:

O banimento da família imperial representou o ponto de partida de um projeto de dissolução. Com o objetivo de pulverizar a memória do Império, o governo republicano anunciou, em 1890, um grande leilão de todos os bens da família imperial a ser realizado no Paço de São Cristóvão. Após acalorado debate pela imprensa, onde simpatizantes de D. Pedro II reagiram à ideia do leilão, esse terminou ocorrendo em 13 etapas diferentes, com objetos que iam desde bibelôs até peças de mobiliário e um carro fúnebre. [...] Contudo, o governo republicano não logrou seu intento. As peças da família imperial configuravam emblemas, sintetizando valores de uma visão de mundo aristocrática. Especialmente os bens associados ao próprio imperador D. Pedro II, como objetos de uso particular, pinturas, retratos. Os amigos da família imperial adquiriram muitas dessas peças, afirmando o culto à nobreza e ao imperador. Muitos deles presentearam outros amigos da família imperial com bens adquiridos nos leilões, acionando um circuito de trocas simbólicas entre si que perdurou ao longo dos anos. Garantiram, com isso, a atualização do passado e preservação dos valores tradicionais. Muitos dos objetos adquiridos no leilão do Paço de São Cristóvão terminaram por serem alocados definitivamente no Museu Histórico Nacional ou, posteriormente, no Museu Imperial de Petrópolis, como resultado de doações dos herdeiros dos amigos da família imperial. ${ }^{122}$

Ou seja, mais do que rever uma posição, o regime republicano, antes de qualquer coisa, assumia sua inabilidade em tratar com o passado imperial; adotava, para isso, um tom contemporizador - "o banimento político da família imperial, em 1889”, como diria, naquela já citada Alocução de 1939, o historiador Max Fleiuss, "não foi propriamente um ato de proscrição, antes uma medida de ordem pública, providência emergente da segurança para o novo regime". ${ }^{123}$ Não conseguira cortar raízes, não

\footnotetext{
121 Lilia M. Schwarcz. As barbas do imperador. Op. cit., p. 499. Ver também Roderick J. Barman. Imperador cidadão. Op. cit, p. 571.

${ }^{122}$ Regina Abreu. A fabricação do imortal. Op. cit., pp. 171 e 172 . Sobre o leilão dos bens imperiais, ver também Lilia M. Schwarcz. As barbas do imperador. Op. cit., pp. 485-487.

123 Assim segue o discurso de Max Fleiuss: "A revogação do banimento da família imperial e transladação para o Brasil dos seus restos mortais é um ato não de reparação, nem de expiação, decerto, mas de soberana justiça histórica. Resgate de uma dívida de perene gratidão nacional”. Max Fleiuss. “Alocução". Op. cit., pp. 190-191.
} 
cavara um fosso entre passado e o presente; o Império e seu segundo monarca permaneciam como sombras. Logo, em lugar da ruptura, era mais interessante adotar a ambiguidade e torná-la proveitosa, recuperar do passado aquilo que fosse o mais interessante; ao invés de apagar a memória do imperador, era mais fácil englobá-la no panteão nacional, operar com as referências e os símbolos. Nesse sentido, perceba-se um detalhe lembrado por Regina Abreu: sintomaticamente, "o mesmo decreto presidencial que criou o Museu Histórico Nacional revogou o banimento da família imperial". Era uma situação temerária, pois, ao se criar um espaço para expor determinada memória (o museu nacional) e permitir novamente a entrada dos banidos no país, abria-se margem para julgar todos os governantes da República anteriores ao decreto. O primeiro diretor do museu, Gustavo Barroso, não deixou de ressaltar a direta relação dos fatores; em texto escrito para a grande imprensa, ele "enunciava uma visão restauradora, demarcando distância em relação aos republicanos positivistas". Contra o sectarismo de alguns exaltados republicanos, o melhor remédio era a celebração do passado imperial, o "culto da saudade". A memória, assim, se fazia presente através de uma perspectiva bastante conservadora, como fica evidente nas palavras de Barroso:

Para felicidade nossa, acabou-se no Brasil a era do descaso pelo passado. Coube ao Exmo. Sr. Presidente Epitácio Pessoa a glória de ter instituído no seu país natal, cujas tradições o estreito sectarismo positivista se tem esforçado por matar, o culto da saudade. Ele o iniciou, revogando o banimento da Família Imperial e fazendo com que viessem repousar na Pátria querida as cinzas daquele que, durante meio século de bondade, dirigira seus destinos. ${ }^{124}$

Os despojos do imperador e de sua consorte, apesar da permissão legal, só chegariam em janeiro de 1921, transportados por um navio de guerra; acompanhados pelo conde d'Eu (1842-1922) - por conta de sua debilidade física e idade avançada, Isabel ficara na França ${ }^{125}$-, foram recebidos com pompa, honrarias militares e um culto quase místico. Era espetáculo bem armado: coordenado pelos membros do IHGB, um grande cortejo seguiu da Praça Mauá à Catedral Metropolitana. A recepção dos despojos, certamente, era um impacto profundo nos corações e mentes: o sentimento cívico ia sendo exacerbado pelo espetáculo vivo da memória. Como disse o escritor e jurista Rodrigo Octavio (1866-1944), no seu livro Minhas memórias dos outros, publicado em 1934: “Os restos do Imperador voltaram para o Brasil, satisfazendo um anseio geral. Eu não protestei; ninguém protestou". Nesse clima de conciliação, conclui

\footnotetext{
${ }^{124}$ Apud: Regina Abreu. A fabricação do imortal. Op. cit., p. 171.

${ }^{125}$ Roderick J. Barman. Imperador cidadão. Op. cit, pp. 572.
} 
dizendo que, "depois de seu longo reinado, não poderia ele [d. Pedro II], em outro lugar, mais justificadamente dormir seu derradeiro sono, do que na terra em que nasceu, que tanto amou e a que tão desinteressadamente serviu". ${ }^{126}$

Nas comemorações, vigora sempre a lógica do espetáculo; afinal, “a realidade dos eventos do passado pouco importa", "é a representação que é privilegiada e, através dela, o imaginário, o que se pode chamar de o poder do sentimento"; mesmo que existisse um desejo de esquecer certos aspectos do passado, isso só podia ser feito através da vivência de "novas imagens". ${ }^{127}$ Assim, sobre a imagem do descaso com o imperador, que fora legado ao exílio, a República depositava outra, bastante gloriosa; neste espetáculo, uma memória era obscurecida pela outra. Além do mais, é possível pensar que, com o retorno, a deposição de d. Pedro II ganhava certo ar de interregno. Antes deposto, agora, era trazido de volta na condição de aliado. Uma antiga ameaça que se convertia em parceria, em propaganda positiva. Sob os auspícios da República, os dois corpos do rei, o político e o natural, voltavam a se encontrar no território da pátria. Capturado por uma nova relação de poder, o monarca retornava a seu lugar. D. Pedro II assumia, um tanto quanto forçadamente, ares de um d. Sebastião moderno; não é sem motivo, portanto, que alguns críticos dos excessos valorativos da memória do imperador, tal com Carlos Sussekind de Mendonça, vão chamar seus oponentes de sebastianistas.

Percebe-se, a partir desse ritual festivo, como d. Pedro II, apesar de todas as dificuldades, era figura interessante para cumprir o papel de herói resgatado, ídolo a ser recolhido às glórias da história nacional; tudo dependia do trato que os líderes republicanos tivessem com sua memória - dessa forma, como comenta Lilia Schwarcz, num “país tão carente de heróis”, d. Pedro II, pelas “mãos das novas elites republicanas,

\footnotetext{
${ }^{126}$ Rodrigo Octavio. Minhas memórias dos outros. Primeira Série. Rio de Janeiro: Civilização Brasileira; Brasília: INL, 1978 (Coleção Relatos do Brasil; v. 119), p. 41.

127 Louis Moreau de Bellaing. "Mémoires de la mémoire : la commémoration". In: L'Homme et la société, n. 75-76, 1985. Synthèse en sciences humaines. p. 243. Disponível no site: http://www.persee.fr/web/revues/home/prescript/article/homso 0018-4306 1985 num $75 \quad 1 \quad 2200$

(Consultado em 03/09/2013). Sobre os debates a respeito dos translado dos despojos, assim como os detalhes da recepção, ver Roderick J. Barman. Imperador cidadão. Op. cit, pp. 571-572; Lilia M. Schwarcz. As barbas do imperador. Op. cit., pp. 503-505. Ver também os textos de Luciana Pessanha Fagundes. "Memórias da monarquia: D. Pedro II no cenário político da década de 20". Anais do XIX Encontro Regional de História: Poder, Violência e Exclusão. ANPUH/SP-USP. São Paulo, 08 a 12 de setembro de 2008. Disponível no site: http://www.anpuhsp.org.br/sp/downloads/CD\%20XIX/PDF/Autores\%20e\%20Artigos/Luciana\%20Pessa nha\%20Fagundes.pdf (Consultado em 03/09/2013); "Entre comemorações, rituais e passados construídos: a Monarquia sob o olhar da Primeira República". Seminário cultura e política na Primeira República: Campanha Civilista na Bahia. UESC, 2010. Disponível no site: http://www.uesc.br/eventos/culturaepolitica/anais/lucianafagundes.pdf (Consultado em 03/09/2013).
} 
passava a figurar ao lado de outros heróis" no "recém-constituído panteão". ${ }^{128} \mathrm{O}$ imperador fora o mandatário de um longo governo no qual se forjaram as bases do Estado nacional; reconhecível a grande parte da população, não era lembrado como um sujeito passional e instável; sua identificação estava, pelo contrário, na figura de conciliador e mediador. Era o monarca ilustrado, sabido e equilibrado; junto a isso tudo - e também por conta disso tudo -, era sagrado e transcendental. Distinguia-se, sensivelmente, dos seus ilustres companheiros de culto patriótico: Tiradentes era o mártir que tinha dado a vida pela liberdade da colônia, porém, e mesmo sendo mito forjado pelos republicamos, podia ser facilmente identificado com ideias de rebeldia; Pedro I, o proclamador da independência, além de muito comentado pela vida privada, tinha a imagem manchada por certo autoritarismo e por ter deixado o Brasil para assumir a coroa portuguesa, a coroa da antiga metrópole (o primeiro imperador teve de aguardar o sesquicentenário da independência, em 1972, para, sob os cuidados dos militares, ter seus restos mortais trazidos ao Brasil). ${ }^{129}$

O espetáculo do retorno, entretanto, não significa um ponto final nas relações entre memória e história. Se entendermos que "a memória coletiva é não somente uma conquista, é também um instrumento e um objeto de poder" ${ }^{\text {"130 }}$, entendemos que, a partir da vinda dos restos mortais ao Brasil, inicia-se uma interessante disputa pela memória do monarca, uma contenda que reflete exatamente um país cuja vida política e cultural encontrava-se em significativa mutação - Se Pedro Segundo / vier aqui / Com história / Eu boto ele na cadeia, versos de Oswald de Andrade que se inserem tão bem nesse

\footnotetext{
${ }^{128}$ Lilia M. Schwarcz. As barbas do imperador. Op. cit., pp. 504-505.

129 A oposição entre pai e filho é um dos fatos que mais pesam no entendimento de d. Pedro II; contraposto ao pai, ele sempre aparece como um bom homem, honrado e correto. José Murilo de Carvalho destaca como, no âmbito pessoal, existiam algumas sensíveis diferenças, mas que, no fundo, escondiam algumas semelhanças: "Com o pai, d. Pedro II tinha pouco em comum por razões de temperamento e, sobretudo, de educação. D. Pedro I era comandado por emoções, às vezes contraditórias, a que não aprendera a impor barreira alguma. Era impulsivo, romântico, autoritário, ambicioso, generoso, grosseiro, sedutor. Era capaz de grandes ódios e grandes amores. D. Pedro II foi educado para não se parecer com o pai. Ensinaram-lhe a controlar ódios e amores, a ser contido, racional, equilibrado, previsível. Por trás do verniz da educação, no entanto, ferviam paixões, se não tão grandes quanto as do pai, pelo menos semelhantes a elas, tanto na vida privada como na vida pública". José Murilo de Casrvalho. D. Pedro II: ser ou não ser. Op. cit, p. 17. A diferença entre eles, mais do que de conteúdo foi, segundo José Murilo, de forma. Com tal fato, surge uma provável hipótese a ser explorada sobre a relação entre o público e o pessoal: talvez, o foco não seja a contradição entre pessoal e impessoal, subjetivo e objetivo, mas sim da possível continuidade entre essas ideias. Assim, quando um governante é bem sucedido, tudo que dele é pessoal retumba positivamente na esfera pública; ao passo que quando um governante é mal sucedido, ocorre o contrário.

${ }^{130}$ Jacques Le Goff. História e memória. Campinas: Editora da Unicamp, 2003, p. 470.
} 
contexto do retorno e das consequentes disputas pela memória. ${ }^{131}$ Somente Getúlio Vargas, um governante que possuía um forte apelo popular e em pleno regime do Estado Novo - quando a 'face pública da autoridade ganhava dimensão 'familiar', havendo identidade-intimidade com o poder" ${ }^{\prime 32}$-, conseguiu estabelecer o monumento (quase) definitivo a Pedro II: seu mausoléu na capela de Petrópolis. A provável intenção de Getúlio, que resultou na perpetuação do imperador, era se colocar como grande governante brasileiro, enterrando definitivamente aquele que poderia ser seu concorrente. O período da Primeira República, por sua vez, caiu em descrédito, sendo entendido como tempo de desvairado liberalismo, corrupção e caos político; tachada de república "velha", restou sombreada entre dois picos: d. Pedro II e Getúlio Vargas. ${ }^{133}$

\footnotetext{
${ }^{131}$ Oswald de Andrade. Pau-Brasil. São Paulo: Globo, 1991, p. 88. Apesar de o poema "Senhor Feudal" ter sido publicado em 1925, no escopo do livro Pau Brasil, pode-se levantar a hipótese de que ele tenha sido escrito alguns anos antes, no momento do retorno - se Pedro Segundo vier aqui com história - dos restos mortais do imperador. Entendido nesse contexto, a "voz poética" que se expressa nesses versos nega a valorização da memória de Pedro II, nega o retorno do espectro porque quer um país que supere as marcas negativas de seu passado. Aproveita o momento de exacerbação nacional e de incerteza política e cultural para apontar um caminho diferente, uma nova memória nacional.

${ }^{132}$ Angela de Castro Gomes. "A política brasileira em busca da modernidade: na fronteira entre o público e o privado". Op. cit., p. 536.

${ }^{133}$ De acordo com Angela de Castro Gomes, é preciso fazer uma releitura da Primeira República, "durante um bom tempo entendida como 'velha' e 'vazia' (a 'república que não foi') pelos próprios historiadores, que não se davam conta do quanto reverberavam acusações e ataques próprios de uma luta política empreendida pelos ideólogos autoritários do pós-1930, defensores de uma proposta antiliberal e centralizadora". In: A República, a História e o IHGB. Belo Horizonte: Argvmentvm, 2009, p. 14. Sobre o mesmo assunto, Lilia Schwarcz comenta o seguinte: "Muitas razões cercam a adoção costumeira de um nome, que não pode ser exclusivamente atribuída a um descuido ou descaso da historiografia. Para começar, não seria a primeira vez que um novo momento atribui a si mesmo os méritos da 'novidade' e jogou para outro período a designação de velho e ultrapassado. É o caso da Revolução de 1930 e do Estado que então se montou, prontamente designado como 'Novo' - Estado Novo. Segundo essa visão, caberia unicamente ao governo de Getúlio Vargas o estabelecimento de uma verdadeira res-publica e a introdução de uma realidade social, moral e política deveras moderna". Mais adiante, a autora completa: "A classificação de República Velha foi o nome que vingou durante bom tempo, foi a maneira como os homens do Estado Novo viram primeiro a si mesmos e, numa operação de contraposição, definiram tudo que os antecedeu. À maneira de Narciso, acharam feio o que não era espelho". Lilia M. Schwarcz. "As marcas do período". In: Lilia M. Schwarcz (coord.) A abertura para o mundo (1889-1930). Op. cit., p. 24 e pp. 32-33. Interessante lembrar, aqui, das palavras de Michel de Certeau: "cada tempo 'novo' deu lugar a um discurso que considera 'morto' aquilo que o precedeu, recebendo um 'passado' já marcado pelas rupturas anteriores. Logo, o corte é o postulado da interpretação (que se constrói a partir de um presente) e seu objeto (as divisões organizam as representações a serem reinterpretadas). O trabalho determinado por este corte é voluntarista. No passado, do qual se distingue, ele fez uma triagem entre o que pode ser 'compreendido' e o que deve ser esquecido para obter a representação de uma inteligibilidade presente. Porém, aquilo que esta nova compreensão do passado considera como não pertinente - dejeto criado pela seleção dos materiais, permanece negligenciado por uma explicação - apesar de tudo retorna nas franjas do discurso ou nas suas falhas: 'resistências', 'sobrevivências' ou atrasos perturbam, discretamente, a perfeita ordenação de um 'progresso' ou de um sistema de interpretação. São lapsos na sintaxe construída pela lei de um lugar. Representam aí o retorno de um recalcado, quer dizer, daquilo que num momento dado se tornou impensável para que uma identidade nova se tornasse pensável". Michel de Certeau. $A$ escrita da história. Op. cit., pp. 15 e 16.
} 
Difícil não lembrar, tratando desse assunto, da metáfora elaborada por Erwin Panofsky (1892-1968) quando fala do distanciamento histórico, materializado na técnica da perspectiva, dos renascentistas do século XVI para com a Antiguidade. De acordo com o crítico e historiador da arte, os renascentistas teriam enterrado o corpo da Antiguidade clássica e construído um monumento fúnebre em sua homenagem, a partir do qual podiam celebrar os antigos; ou seja, "pela primeira vez apareceu o passado clássico como totalidade desligada do presente". Os renascentistas perceberam que tinham perdido a Antiguidade, logo, a despojaram de realidade; dessa forma, "o mundo clássico deixou de ser uma possessão e uma ameaça para se converter em um objeto de nostalgia apaixonada que se revelou expressão simbólica". Os medievais, por sua vez, haviam velado o cadáver da Antiguidade e, tão presos à materialidade e aos detalhes do corpo, não conseguiam idealizá-lo, não criavam distanciamento e nem perspectiva. $\mathrm{O}$ peso do passado, entre o velório e o enterro, evidentemente, muda de carga; da mesma forma, se transforma a capacidade de indicar caminhos para o presente e o futuro. Como diz Panofsky:

A Idade Média tinha deixado insepulta a Antiguidade, e alternativamente galvanizou e exorcizou seu cadáver. O Renascimento chorou ante sua tumba e tratou de ressuscitar sua alma: no momento fatalmente propício, o conseguiu. Por isso o conceito medieval de Antiguidade foi tão concreto e, ao mesmo tempo, tão incompleto e deformado; enquanto que o moderno, elaborado gradualmente ao longo dos últimos trezentos ou quatrocentos anos, é completo e consequente, mas, se me permite dizê-lo, abstrato. E por isso os renascimentos medievais foram transitórios, enquanto que o Renascimento foi permanente. As almas ressuscitadas são intangíveis, mas têm as vantagens da imortalidade e da ubiquidade. Daí que o papel da Antiguidade clássica, depois do Renascimento, seja um tanto esquivo, mas, por outro lado, onipresente: e mutável somente ao custo de uma mutação de nossa civilização como tal. ${ }^{134}$

É quando se celebra o passado que se cria perspectiva sobre ele; é com essa perspectiva que se podem fazer projeções sobre o futuro. Até o centenário da

\footnotetext{
134 "La Edad Media había dejado insepulta a la Antigüedad, y alternativamente galvanizó y exorcizó su cadáver. El Renacimiento lloró ante su tumba y trató de resucitar su alma: y en un momento fatalmente propicio lo logró. Por eso el concepto medieval de la Antigüedad fue tan concreto y al mismo tiempo tan incompleto y deformado; mientras que el moderno, desarrollado gradualmente a lo largo de los últimos trescientos o cuatrocientos años, es completo y consecuente pero, si se me permite decirlo, abstracto. Y por eso los renacimientos medievales fueron transitorios, mientras que el Renacimiento fue permanente. Las almas resucitadas son intangibles, pero tienen las ventajas de la inmortalidad y de la ubicuidad. De ahí que el papel de la Antigüedad clásica después del Renacimiento sea un tanto esquivo pero, por otra parte, omnipresente: y mutable sólo a costa de una mutación de nuestra civilización como tal". Erwin Panofsky. Renacimiento y renacimientos en el arte occidental. Madrid: Alianza Universidad, 1994, p. 172 e 173. Sobre o assunto, ver também: Laura de Mello e Souza. "Idade Média e Época Moderna: fronteiras e problemas". In: Signum, Revista da Associação Brasileira de Estudos Medievais, nº7, 2005, pp. 223248.
} 
Independência, o regime republicano velara o corpo do monarca; com Vargas, foi dado o passo seguinte, a construção do monumento fúnebre, a tentativa de consolidar uma memória, uma periodização e uma idealização. Do concreto, incompleto e deformado, chegou-se a um d. Pedro II completo e consequente; foi-se, assim, do velório ao enterro. Dessa maneira, os ideólogos do Estado Novo elaboraram uma forma quase ideal de operar com a figura de d. Pedro, sem ter, para isso, de sofrer com nenhum peso na consciência, nenhum arrependimento ou culpa; mais que isso, conseguiram, no mesmo movimento, lançar culpas aos seus rivais, os políticos da Primeira República. Pode-se dizer que Vargas, tal qual um renascentista em relação à Antiguidade, criou perspectiva em relação ao monarca. Nesse sentido, talvez seja possível, então, pensando a partir das ideias de Maurice Halbwachs, imaginar que, com o Estado Novo, quebrou-se uma “corrente de pensamento" para se estabelecer uma história esquemática, envelopada em períodos.

Apesar de tudo, dessa tentativa de fixar a memória de d. Pedro II, o espectro do imperador continua a rondar, pois, conforme a argumentação de Panofsky, quando se opera com o passado, por um lado, é possível completá-lo; mas, por outro, ele fica mais abstrato e passa a ter os poderes da imortalidade e da ubiquidade. Logo, se o corpo do rei foi capturado pelo rito memorialístico oficial, o inverso não deixou de acontecer; afinal, como diz Beatriz Sarlo, "o retorno do passado nem sempre é um momento libertador da lembrança, mas um advento, uma captura do presente". ${ }^{135}$ Trata-se, portanto, de um jogo de capturas entre o passado e o presente; quer-se controlar o espectro, mas ele teima em continuar a rondar. Isso fica expresso no documento capital para a elaboração desta pesquisa: a reportagem laudatória publicada na revista Veja, em 14 de novembro de 2007. Quando se torna interessante, quando isso pode adquirir significado no presente, é permitido resgatar o monarca e repercutir os discursos que sobre ele fizeram. Essa utilização da memória indica como o modelo de política enfeixado na figura do monarca - o seu arranjo produtivo de duplos - não deixou de ser efetivo e, talvez, necessário para a vida pública. Fica, nessa linha de pensamento, uma pergunta no ar: estamos falando, então, e parafraseando novamente Panofsky, de um paradigma que só seria modificado a custo de uma mutação de nossa organização política enquanto tal? O certo é que, no jogo político brasileiro, o modelo duplo e ambíguo do imperador não perdeu a validade; Regina Abreu ressalta, mesmo que não

\footnotetext{
${ }^{135}$ Beatriz Sarlo. Tempo passado. Op. cit., p. 9.
} 
tratando dos mesmos termos aqui adotados, como d. Pedro II se tornou "um elo mediador" e "um modelo paradigmático de estadista":

no Brasil, o imperador D. Pedro II representou um modelo paradigmático de estadista. Pedro Calmon ressalta "seu perfil de magistrado, a mania de erudição, o gosto das letras, o irredutível gênio civil". O monarca representou para muitos o elo mediador entre a emergência da modernidade - seu caráter inovador e as bases da tradição. Europeu, amigo das ciências, de poetas, filósofos, gênios da música, D. Pedro II simbolizou, para seus contemporâneos e as gerações que se seguiram, a passagem do Brasilcolônia para o Brasil-nação moderno e soberano. Governando durante 40 anos, deixou, entre seus legados, para a nação republicana, seu próprio perfil de estadista, representado iconográfica e literariamente e seguido por muitos de seus colaboradores. ${ }^{136}$

Getúlio Vargas, ao fundir ambiguidades, fazia uma política excessivamente explícita, faltava-lhe a capa de imparcialidade e cultura do imperador, sua moderação e comedimento; o culto de Pedro II é uma tentativa de aproximação e, consequentemente, de purificação. Uma maneira, em suma, de suavizar o arranjo de duplos, de se assemelhar "ao segundo imperador em seu desprezo pelas armadilhas do poder, sua persistência silenciosa, sua capacidade de manipular homens e eventos e a concentração de poder em suas mãos". ${ }^{137}$ Isso, porém, não é tarefa fácil, haja em vista, por exemplo, os casos dos dois últimos presidentes do Brasil: Fernando Henrique Cardoso, o intelectual, e Luiz Inácio Lula da Silva, o popular. Ambos, cada qual com seu repertório, precisaram se adaptar, mudar e reforçar sua transcendência compactuando com o outro lado da moeda. As dificuldades e percalços desse processo, sintomaticamente, não ficam ligados à imagem pública (afinal, ambos saíram por cima). Os dilemas surgem, e não há ingenuidade nenhuma nessa leitura (afinal, não se está defendendo, aqui, uma "política sem políticos"), no intelectual que, como diz Paulo Arantes, coloca em cheque toda uma tradição crítica, transformando-a - através da autoridade do conhecimento -, em um punhado de ótimas formulações face à tragédia cotidiana, uma tradição de nada, mero instrumento de dominação de classe. ${ }^{138} \mathrm{Ou}$ no

\footnotetext{
${ }^{136}$ Regina Abreu. A fabricação do imortal. Op. cit., p. 51.

${ }^{137}$ Roderick J. Barman. Imperador cidadão. Op. cit, p. 573.

${ }^{138} \mathrm{O}$ texto, do qual foi retirada a citação a seguir, foi publicado em 27 de maio de 2001: "Os paulistas no poder não são quaisquer, tampouco a desgraça mental que patrocinam. À sua própria revelia, bem entendido, conforme aprofundavam o ponto final em que chafurdamos, iam avançando, com fins apologéticos os mais rasos, nos fundos críticos acumulados pela referida tradição e, por esse caminho de autodestruição do saber herdado, convertendo ponto por ponto o que antes esclarecia e prometia libertação, no seu exato oposto conformista, como se quisessem demonstrar numa derradeira pirueta, cínica ou asnática, vá lá saber, que, de fato, cedo ou tarde toda Ilustração, central ou periférica, acaba se convertendo no seu contrário. A nova mitologia dos fatos se expressa então no autodeslumbramento com que a feroz burrice dos inteligentes se congratula consigo mesma. Porém, o espírito crítico saqueado e
} 
líder sindical que abdicou da postura passada, elaborou novo arranjo focado nas necessidades pragmáticas, tornou-se estadista, virou uma ameaça que somente oferecia paz-e-amor e, apesar de não ter origens semelhantes às do seu antecessor (este gozava, novamente segundo Arantes, de "impunidade de classe" e de "um bem armado aparato sociológico"), continuou a aplicar, em alguma parte, a receita econômica herdada, alvo de tantas críticas nos oito anos anteriores. Assim, a pertinência dessas hibridizações, desse vivo legado do segundo imperador, mesmo com todos os problemas e paradoxos que possa trazer junto consigo, faz-se notar tão bem na

continuidade por assim dizer "espiritual" lograda por um sistema de dominação social tão acachapante que pode se dar ao luxo de se perpetuar entregando o comando primeiro a um sociólogo acometido de apoteose mental, depois a um líder sindical generosamente empenhado em levar todas as classes sociais à mesa da comunhão nacional. ${ }^{139}$

A questão central, portanto, quando se trata de d. Pedro II - e, por certo, de seu legado político -, é a dificuldade de encontrar um locus interpretativo presente nos arranjos entre a história e a memória, o indivíduo e a pessoa, o cidadão e o monarca; reconhecer o alguém que está entre o homem e a idealização, aquele que sobra quando se perscruta as combinações entre as diferentes instâncias. Lilia Schwarcz, lembrando todas as referências históricas e simbólicas que perpassam a pessoa do monarca, dá monta desses dilemas interpretativos:

Imperador de 1840 a 1889 , d. Pedro II teve sua vida contada a partir de episódios repletos de dramaticidade e destacada com base neles. Primeiro monarca nascido no Brasil, Pedro de Alcântara foi comparado ao Menino Jesus na tradição portuguesa, revisto como Imperador do Divino na ladainha brasileira, entendido como novo d. Sebastião pelos últimos fiéis das previsões de Vieira. Filho de Bragança, Habsburgo e parente direto dos Bourbon, d. Pedro era reconhecido como um pequeno deus europeu, cercado por mestiços. Órfão de mãe com um ano, de pai aos dez, imperador aos catorze e exilado aos 64 , no seu caminho é difícil notar onde se inicia a fala

barateado parece se vingar quando a antiga teoria crítica passa a funcionar como uma chinfrinzinha teoria tradicional de coisa nenhuma e ainda por cima mobilizada com a pompa e circunstância dos grandes acacianos para os fins da mais trivial dominação de classe". Paulo Eduardo Arantes. "Apagão". In: Zero à esquerda. São Paulo: Conrad, 2004 (Coleção Baderna), p. 24.

${ }^{139}$ Paulo Eduardo Arantes. "Beijando a cruz". In: Zero à esquerda. Op. cit, pp. 303 e 304 . Acerca da presença de d. Pedro II na vida política atual, a seguinte passage dá mostra clara disso: "Grande parte dos gastos nominais do bolsinho imperial, como se dizia, ia para esmolas, doações a entidades beneficentes e científicas, pensões. Muitos pobres de São Cristóvão eram sustentados por esmolas, que recebiam aos sábados, uma espécie de bolsa-família em pequena escala. No ano de 1857, foram gastos noventa contos com esmolas, muito mais do que os vencimentos anuais de todos os seis ministros. No mesmo ano, pensões e aposentadorias consumiam cinquenta contos". José Murilo de Carvalho. D. Pedro II: ser ou não ser. Op. cit, p. 98. 
mítica da memória, quando acaba o discurso político e ideológico; onde começa a história, onde fica a metáfora. A saída é acompanhar passo a passo as trajetórias que envolvem a figura de d. Pedro II, que de órfão da nação se transforma em rei majestático; de imperador tropical e mecenas do movimento romântico vira rei cidadão, para finalmente imortalizar-se no mártir exilado e em um mito depois da morte, com vistas a recuperar não tanto a sua história, mas antes sua memória, ou melhor, a seleção de determinadas memórias nacionais. ${ }^{140}$

Dessa maneira, como bem alertado por Schwarcz, com d. Pedro II - "que parece aglutinar representações distintas" - se vai e volta, em distâncias bastante curtas, do mito à história, do geral ao detalhe - "mito e história desenham igualmente uma memória nacional esculpida no detalhe"141 -, do macro ao micro, do fato à ficção. A partir do fatídico "lápis azul" que usava para rasurar as margens dos documentos, por exemplo, é possível fazer elogios a sua acuidade ou criticar sua completa falta de ação; da leitura de seus Sonetos do exílio, é viável tecer loas sobre seu domínio da arte poética ou, assumindo postura iconoclasta, denunciar a fraude de versos apócrifos e expandi-la para a fraude de um reinado apócrifo (assunto que será tratado mais adiante, quando se falar de Medeiros e Albuquerque). Contudo, apesar dos riscos envolvidos na tarefa, para a criação do mito, esse vai e volta entre o detalhe e o geral é movimento estruturante, pois, escondendo falhas e escamoteando as tramas, se trata de uma dinâmica que consolida a si própria, cria uma espécie de autolegitimação. Afinal, como bem comentado por Beatriz Sarlo, "a proliferação do detalhe individual fecha ilusoriamente as fendas da intriga e a apresenta como se ela pudesse ou devesse representar um todo, algo completo e consistente porque o detalhe o certifica, sem ter de mostrar sua necessidade". ${ }^{142}$

Não sem motivo, então, que nessa amálgama de referências, uma das representações mais correntes que se fez de Pedro II, à primeira vista uma contradição, é uma mescla de leituras positivadas e entendimentos críticos: o mesmo imperador que é

\footnotetext{
${ }^{140}$ Lilia M. Schwarcz. As barbas do imperador. Op. cit, p. 21.

${ }^{141}$ Lilia M. Schwarcz. As barbas do imperador. Op. cit, p. 12 e p. 487.

${ }^{142}$ Beatriz Sarlo. Tempo passado. Op. cit., p. 52. Sobre os detalhes, o seguinte comentário de Maurce Halbwachs vai no mesmo sentido: "Ce qui justifie aux yeux de l'historien ces recherches de détai, c'est que le détail ajouté au détail donnera um ensemble, que cet ensemble s'additionnera à d'autres ensembles, et que, dans le tableau total qui résultera de toutes ces sommations successives, rien n'est subordonné à rien, n'importe quel fait est aussi intéressant que tout autre, et mérite autant d'être releve et transcrit". ["O que justifica, aos olhos do historiador, essas procuras pelo detalhe, é que detalhe juntado a detalhe dará um conjunto; esse conjunto se adicionará a outros conjuntos; e que, no quadro total que resultará de todas essas somas sucessivas, nada está subordinado a nada, pouco importa se um fato é tão interessante quanto todos os outros, e mereça da mesma forma ser realçado e transcrito"]. Maurice Halbwachs. La mémoire collective. Op. cit., p. 136.
} 
reverenciado como honesto, correto e erudito, é, ao mesmo tempo, também tachado de demagogo, desinteressado e idealista. Uma imagem, assim, não exclui a outra; da mesma forma, uma memória não bloqueia a outra. Entre detalhes e generalizações, ambas constituem as duas faces de uma mesma moeda. É o risco da duplicidade, que pode lançar luz sobre brechas e fazer com que alguns aspectos se revelem indesejados. Mário de Andrade (1893-1945), para citar um caso curiosíssimo, ao falar da postura conciliadora que assumiram membros do Partido Democrático (PD) e correligionários do Partido Republicano Paulista (PRP) quando da eclosão da Revolução de 1930, transforma Pedro II em adjetivo:

Quando arrebentou a revolução, os democráticos exultaram. Xingaram o presidente de uma porção de culpas. Os perrepistas apreensivos secundavam que não era tanto assim. Entre boatos e comunicados oficiais, tudo mentira, não se sabia a quantas o Brasil andava e pela primeira vez, fora os casos de doença grave, a angústia sufocava o peito mansamente respirador da cidadinha. Oito dias, doze dias, não se aguentavam mais! Os chefes perrepistas se reuniram, confabularam bem pedros-segundos, depois saíram da Câmara e foram procurar os democráticos que se reuniam na porta do Comércio e Indústria. ${ }^{143}$

Confabular bem pedros-segundos, imagem das mais interessantes. O fato de transformar substantivo próprio em adjetivo é manobra que traz intrínseca enorme carga de significados. Para certa linha interpretativa, uma das mais marcantes características do governo adulto de Pedro II foi exatamente a conciliação, o abafamento de possíveis conflitos intraelites desestabilizadores da ordem nacional. O imperador, pela pena de Mário de Andrade, emerge como símbolo de politicagem e arranjos partidários. $\mathrm{O}$ adjetivo, dessa forma, demonstra como tais práticas tinham raízes profundas no Brasil; como o debate, muitas vezes, era esvaziado pela disputa de espaço nas esferas governamentais. Diante da ameaça maior, ficar sem poder algum no novo cenário, democráticos e perrepistas superam desavenças e selam o acordo:

- Olhem, vamos fazer uma coisa [diz o perrepista]: não vale a pena a gente derramar sangue, nem estar agora diz-que brigando por causa da revolução. O melhor é fazer assim: se a revolução ganhar, nós entregamos tudo para vocês, tomem conta da Câmara, da coletoria, do jornal, tá tudo em dia, só falta fechar o balanço do mês. Não se deve nada e tem vinte e dois contos de arrecadação em caixa. Mas se o governo ganhar, continua tudo na mesma, está feito? ${ }^{144}$

\footnotetext{
${ }^{143}$ Mário de Andrade. "Revolução Pascálica". In: Os filhos da Candinha. Rio de Janeiro: Agir, 2008, p. 94.

${ }^{144}$ Mário de Andrade. "Revolução Pascálica". Op. cit, p. 94.
} 
O potencial irônico, diretamente ligado à escrita solta e oralizada, é imenso. D. Pedro II, de exemplar segundo monarca do Brasil, é transformado em modelo, figura de linguagem, alegoria de poder, em uma concepção de fazer política. Portanto, não se trata de saber exatamente quem ele foi ou o que fez, e sim o que ele representou, aquilo que dele ficou na cultura política. Curiosamente - e acentuando mais a ironia desses adjetivos todos -, Menotti Del Pichia (1892-1988), em crônica publicada no ano de 1920 no Correio Paulistano, demonstrara todo o seu entusiasmo pela figura de Mário de Andrade chamando-o - além de Padre Vieira, o que já seria suficiente - de Pedro II: "músico, crítico arguto e sincero, franco sem ser ríspido - numa palavra esteta, profundamente esteta. Mário é modesto como Pedro II e estudioso como o Padre Vieira". ${ }^{145}$ Um Mário de Andrade, portanto, bem pedro-segundo. Entra em cena, agora, outra imagem do imperador, o arranjo se rearranja: o erudito e intelectual, aquele que, apesar de toda sapiência, sempre foi modesto e centrado. Intrigam as diferentes atitudes tomadas pelos dois escritores diante da memória do imperador; no entanto, intriga ainda mais saber que as duas posições dialogam com as ideias correntes que se tem sobre o personagem. Uma, a de Mário, foca o aspecto político, é sarcástica e negativa; a outra, a de Menotti, o erudito, é franca admiração e reconhecimento pelo homem. Qual delas a mais correta, a mais profunda e coerente? No contexto de uma política feita em "situação de fronteira", entre o pensamento social e o imaginário político, não estariam, ambas, muito bem arranjadas, uma retroalimentando a outra? ${ }^{146} \mathrm{O}$ fundamental, portanto, é entender o sentido que as representações adquirem, quais aspectos elas tocam, qual a carga de significados que carregam, quais controvérsias originam.

Nesse sentido, a relação entre memória e história, que emerge múltipla e variável, pode se converter em nevoeiro a pairar sobre o passado; a interpretação se vê em risco de desequilibrar-se, ainda mais quando centrada numa figura como Pedro II, tão propensa a personalismos e sentimentalismos. Tudo isso, entretanto, feito com certa intencionalidade; como afirma Jacques Le Goff: "tornar-se senhores da memória e do esquecimento é uma das grandes preocupações das classes, dos grupos, dos indivíduos que dominaram ou dominam as sociedades históricas". ${ }^{147}$ Dessa forma, o que ficou do passado não é mostra exata daquilo que existiu (o que, de qualquer forma, é impossível

\footnotetext{
145 Apud: Mário da Silva Brito. História do modernismo brasileiro: antecedentes da Semana de Arte Moderna. Rio de Janeiro: Civilização Brasileira, 1978, p. 172.

${ }^{146}$ Angela de Castro Gomes. "A política brasileira em busca da modernidade: na fronteira entre o público e o privado". Op. cit., p. 499.

${ }^{147}$ Jacques Le Goff. História e memória. Op. cit, p. 422.
} 
de acontecer), e sim resultado de escolhas intelectuais e ações pautadas em interesses específicos: tornar d. Pedro II ilustrado é ressaltar sua transcendência, seu aspecto apolítico (que, evidentemente, é bastante político); fazê-lo abolicionista é querer mostrar que a luta antiescravista esteve sempre em contato com a oficialidade; vesti-lo de republicano é tentar aproximá-lo do regime de 1889. Os monumentos em sua homenagem - tal como o mausoléu de Petrópolis -, qual seja a forma que tiverem, são tentativas de consolidar, controlar e adequar sua memória e legado. ${ }^{148}$

Seccionar d. Pedro II em monumentos, entretanto, para além de glórias e celebridade, favorece também, como no caso de Mário de Andrade, por paradoxal que pareça, todo tipo de subentendido, caricatura e gozação. Isso é prova de que a criação de símbolos e idealizações não é tarefa simples, não se dá no vazio; é preciso encontrar um chão firme sobre o qual agir e formular meios de manter impoluta a criação, uma "corrente de pensamento" na qual inseri-la. Ainda mais quando se trata de figura ambígua, um monarca que transitou entre temporalidades e concepções distintas de sociedade, que representava a unidade e continuidade com a tradição e, a partir de meados do século XIX, a própria inserção do Brasil na modernidade. Trata-se de um representante quase bifronte, que olha para duas direções e acumula, em si, contradições; como afirma Regina Abreu: “a aproximação de D. Pedro II com a ciência e os ventos da modernidade não impedia que o Império deixasse de estar identificado com o atraso colonial." ${ }^{149}$ Nessa situação, os riscos são infindos, as fronteiras entre a glória e a piada são porosas; caminha-se sobre o fio da navalha. As brincadeiras e piadas, por sua vez, também não condizem plenamente com o que foi o reinado de $d$. Pedro - obviamente que, nas construções humorísticas, a questão central não é o rigor histórico e documental, e sim a subversão dos fatos. Como o foco é a primeira metade

\footnotetext{
148 “O monumento tem como característica o ligar-se ao poder de perpetuação, voluntário ou involuntário, das sociedades históricas (é um legado à memória coletiva) e o reenviar a testemunhos que só numa parcela mínima são testemunhos escritos”. In: Jacques Le Goff. História e memória. Op. cit., p. 536.

149 "O peso das tradições escravista e colonial obstruía o desenvolvimento de um éthos burguês e moderno. A noção negativa da categoria trabalho, associada à escravidão, era questionada por segmentos das elites que pleiteavam uma nova ética do trabalho. Esses setores opunham-se à política paternalista do Estado monárquico, onde a população pobre era confinada à margem do sistema produtivo e organizada em torno dos senhores e dos coronéis do setor agrário-exportador. O que as elites modernizantes reivindicavam era a incorporação dos setores mais pobres no mercado de trabalho sob uma ótica individualista e burguesa. Os intelectuais da modernização defendiam a premência da constituição de uma base real para o exercício do contratualismo burguês. Por outro lado, as populações à margem nas grandes cidades constituíam ameaça para o conjunto das elites: as cidades assumiam feições potencialmente explosivas” Regina Abreu. A fabricação do imortal. Op. cit., p. 92; ver também p. 106.
} 
do século XX, citemos um exemplo, o poema "Quinze de novembro", de Murilo Mendes:

Deodoro todo nos trinques
bate na porta de Dão Pedro Segundo.
- Seu imperadô, dê o fora
que nós queremos tomar conta desta bugiganga.
Mande vir os músicos".
"Pois não meus filhos não se vexem
me deixem calçar as chinelas
podem entrar à vontade:
só peço que não me bulam nas obras completas de Vítor Hugo". ${ }^{150}$

É sabido que Murilo Mendes, ao relacionar as suas obras completas, buliu com os textos: deixou de fora poemas jocosos, vários dos quais tratam de episódios da história do Brasil. Isso, porém, não desqualifica seus versos, nem o teor agudo de sua crítica e gracejo. O poeta, livre e espirituoso, escancara o descaso das elites governantes com o país. Ao contrário de certa interpretação histórica, que destaca a desconfiança, por fidelidade ao imperador, de Deodoro da Fonseca (1827-1892) com o golpe, o marechal surge, nestes versos irregulares, em traje de gala, nos conformes para assumir o poder e, sem cerimônia ou qualquer formalidade, falando tal qual um soldado raso e como se tratasse com um, praticamente enxota Pedro II do trono. Assume a "bugiganga" sem meias palavras. O militar está com sede de poder e com pressa para assumi-lo. O velho monarca, enfadado, responde em tom educado e patriarcal (força do hábito?) que vai embora sem problema, não há motivo para desavença, é até alívio livrar-se de fardo tão pesado. Só pede, encarecidamente, única e absurda exigência para quem sai derrubado do poder: façam tudo, estejam à vontade, só não mexam - dezenas de imensos volumes, o que se materializa no comprimento do último verso - nas obras completas do Vítor Hugo.

O país, uma "bugiganga"; os republicanos, ansiosos demais por governar; o imperador, não resiste e não quer nada de importante, ou provavelmente nunca quis - ao invés de governar, ficou lendo a vasta obra completa do romântico francês; ou, talvez fosse o caso de dizer de maneira diferente: por ficar lendo e se assumir como sábio desinteressado é que governou por longo tempo, na surdina e oficiosamente. Murilo Mendes, dessa maneira, aborda d. Pedro como caricatura. ${ }^{151}$ No entanto, não se trata

\footnotetext{
${ }^{150}$ Murilo Mendes. "Quinze de novembro", In: Poemas e Bumba-meu-poeta. Rio de Janeiro: Nova Fronteira, 1988, p. 22.

${ }^{151}$ Lembro, aqui, de algumas palavras breves de José Paulo Paes: "Pode ser que esses adversários poéticos da Monarquia se tenham excedido nas objurgatórias contra alguém cujo maior crime foi a 
somente - e isso o mais importante - de uma crítica pessoal e direcionada; o foco é o marasmo a que o país se viu lançado durante décadas e no qual continuou a viver (afinal, o poema foi escrito na segunda metade da década de 1920). O que está em jogo, então, não é a crítica a um ou outro regime, esse ou aquele governante. Seu tema é amplo: escancarar uma concepção de política excludente e conservadora, que teria em d. Pedro II um de seus monumentos.

mediocridade. Mas o exagero é próprio da paixão e, ademais, gozam os poetas de certa liberdades que os historiadores, na sua imparcialidade compulsória, reprovam e desautorizam, muito embora, no íntimo, as invejem danadamente...". José Paulo Paes, "O régio saltimbanco". In: Armazém literário: ensaios. Organização de Vilma Arêas. São Paulo: Companhia das Letras, 2008, p. 149. O comentário diz respeito ao poema "O régio saltimbanco", de Fontoura Xavier, mas vem bem a calhar. Lembro, ainda, que no seu livro Novas cartas chilenas, de 1954, José Paulo Paes fez, ele também, alguns poemas sobre d. Pedro II. Um dos mais interessantes, que casa bem com o de Murilo Mendes, intitula-se "Cem anos depois": "Vamos passear na floresta / Enquanto D. Pedro não vem. / D. Pedro é um rei filósofo, / Que não faz mal a ninguém. // Vamos sair a cavalo, / Pacíficos, desarmados: / A ordem acima de tudo, / Como convém a um soldado. // Vamos fazer a República, / Sem barulho, sem litígio, / Sem nenhuma guilhotina, / Sem qualquer barrete frígio. // Vamos, com farda de gala, / Proclamar os tempos novos, / Mas cautelosos, furtivos, / Para não acordar o povo". In: Um por todos: poesia reunida. Introdução de Alfredo Bosi. São Paulo: Brasiliense, 1986, p. 183. 


\section{CAPÍTULO 4}

\section{Um monarca, muitas versões (1920-1940)}

\begin{abstract}
"Naturalmente, é do conhecimento corrente que os acontecimentos históricos costumam receber mais do que uma única interpretação. Mas gostaria de fazer dois comentários sobre este fato inegável da vida do historiador. As interpretações podem antes complementar do que contradizer umas às outras, assim como diferentes mapas do mesmo território podem ser igualmente corretos, sem conflitar em ponto algum. A coexistência das interpretações, em suma, é possível e mesmo provável, mesmo que tais interpretações sejam, no bom sentido do termo, parciais. Mas, quando as interpretações se contradizem mutuamente, o historiador não pode se resignar a esses conflitos sob a alegação de que são intrínsecos a seu material ou à natureza da pesquisa histórica. São precisamente os conflitos de interpretação que dão a medida do grau insatisfatório em que se encontram os conhecimentos da disciplina histórica, naquele aspecto específico".
\end{abstract}

Peter Gay, em $O$ estilo na história

Após traçar um quadro geral, o que evidencia a presença, entre as décadas de 1920 e 1940, da memória de d. Pedro II nos cenários político e cultural brasileiros, é preciso se deter com mais apuro sobre os textos, notadamente os historiográficos. Neste capítulo, o que se propõe são leituras cuidadosas de obras que tratam do imperador, cujos autores, oito ao todo, demonstram, em alguns momentos, ser complementares; em outros, se contradizem, revelando opiniões distintas e se inserindo em um debate. A intenção, em suma, é procurar proximidades e diferenças, a fim de identificar diálogos e controvérsias. O que se pode perceber, com essas leituras, são diferentes formas de tratar com o passado e com a história nacional; emergem, assim, memórias elaboradas a partir de instituições, posições e interesses políticos específicos, narrativas tecidas através de variados estilos e com distintas finalidades. Lançar vistas a essas obras é algo fundamental no escopo dessa pesquisa, não só por garantir-lhe uma base documental consistente, mas, também, por permitir pensar com cautela acerca das relações entre memória e história. Dessa maneira, tratando de textos em sequência e inseridos no contexto, é possível ter um entendimento crítico da memória elaborada a respeito de d. Pedro II. Tal trabalho revela que, antes de lançar novas interpretações e representações, é preciso olhar para trás; de certa forma, é preciso compreender o tecido bem tramado 
da memória antes de continuar a aumentá-lo. Somente com retidão se pode alcançar isso; só assim se identificam divergências e conflitos, se evita o excesso do entendimento fácil e a reiteração de idealizações e preconceitos.

Ao invés do critério cronológico, as obras foram organizadas por conta de sua opinião acerca do imperador. Textos favoráveis e tendentes a criar interpretações positivas, tais como os de Carlos Magalhães de Azeredo, Pedro Calmon, Max Fleiuss e Heitor Lyra, estão reunidos na seção Flores sem espinhos. Já aqueles que apresentam um entendimento negativo, alguns almejando mesmo ser devastadores, estes, estão na seção Flores com espinhos; nela, reúnem-se obras de Vicente Licínio Cardoso, Capistrano de Abreu, Medeiros e Albuquerque e Carlos Sussekind de Mendonça. A diferença fundamental está na maneira como os autores resgatam a memória de d. Pedro II: na primeira seção, o arranjo de duplos é retomado, sobretudo, por seu aspecto produtivo, apolítico e transcendente; na segunda, por sua face arriscada, política e imanente. Ressalte-se que, o fato de existirem dois grupos distintos, não significa que, no interior deles, não haja especificidades e características particulares; como se verá, mesmo que ocorram diálogos e existam temas em comum, nenhum texto é igual ao outro, nenhuma maneira de entender as ambiguidades é única. Além disso, nenhuma dessas abordagens está isenta de contradições e subentendidos - o que revela, acima de tudo, como querer pensar a política do monarca sem levar em conta a imbricada relação de seus aspectos múltiplos é uma postura temerária. Das opiniões à linguagem, do lugar de onde se fala ao caráter formal da obra, do contexto à documentação, do repertório às intenções políticas, é grande a gama de variedades. Isso revela, antes de qualquer coisa, a intensidade do tema, a importância que alcançava nesses anos de confluência; revela, também, constantes esforços de apropriação e arranjo da memória. E é isso que é preciso identificar, problematizar e, na medida do possível, compreender.

Obs.: A fim de dinamizar a leitura e evitar quaisquer mal-entendidos, desde que isso não fosse comprometer a ideia do autor, a ortografia dos textos citados foi atualizada. 


\section{1. FLORES SEM ESPINHOS}

\section{1. 1. Carlos Magalhães de Azeredo: um imperador bastante pessoal}

"Napoleão I, saudando Goethe, disse: Vous êtes un homme! Pôncio Pilatos, apresentando Jesus à turba urrante de Jerusalém, disse: Ecce homo! Contemplando a nobre figura de Dom Pedro II, na meditação e no trabalho, nos desígnios e nos atos, no fastígio do trono e na tristeza do exílio, podemos também dizer que ele foi, no mais belo, mais alto, mais compreensivo valor deste termo, um homem!"

Carlos Magalhães de Azeredo, em Dom Pedro II. Traços de sua physionomia moral.

Quando beirava o "décimo quarto lustro", o diplomata e escritor Carlos Magalhães de Azeredo começou a escrever suas Memórias. O livro que cobre a primeira parte de sua vida, o único que efetivamente chegou a público, carrega nas tintas da pessoalidade e da escrita literária, o que, de qualquer forma, já seria esperado quando se trata de um texto desse gênero. Isso, porém, ao invés de empecilho e subentendido, pode ser de grande ajuda; afinal, como se verá, o entendimento que Azeredo tem de d. Pedro II é bastante ligado à sua própria memória; sua vida e a do imperador, no decorrer de sua interpretação, possuem laços em comum. Nas suas obras, o pessoal e o histórico pertencem a um mesmo conjunto memorialístico, não havendo distinção notável e nem estranhamentos entre aquilo que diz respeito ao autor e aquilo que diz respeito ao país. Sobre isso, o início do livro autobiográfico é revelador, pois demonstra claramente o elo inegável, evidencia a conexão entre sujeito e nação: "nasci na cidade do Rio de Janeiro, a 7 de setembro de 1872. Era um dia de grande gala; um grande dia; um dia histórico. Marcava o primeiro meio século de vida independente e soberana do Brasil". Não se trata simplesmente de uma coincidência, mas de uma espécie de ligação profunda e emblemática. De acordo com o autor, mais do que o cinquentenário da independência, a época do seu nascimento era de esplendor e grandezas:

o Império estava no seu glorioso apogeu; uma guerra justa - guerra longa e justa - lhe granjeava os louros da vitória, corroborando a sua influência e o seu prestígio no continente americano; logo depois, uma lei consagrava a liberdade dos nascituros filhos de ventre escravo, estancando as fontes perpetuadoras da instituição nefanda, e atraindo sobre a nossa pátria os aplausos das outras nações cristãs e civilizadas. À hora em que eu nasci - ao romper da aurora - as fortalezas da baía salvavam, as bandas dos quartéis e outras espalhavam festivas e vibrantes as notas do hino nacional, o povo 
todo despertava num frêmito de júbilo e de orgulho... Era uma bela entrada, a minha, neste mundo. ${ }^{152}$

Fica perceptível, desde o princípio, do momento mesmo de seu próprio nascimento, ocorrido em dia de júbilo patriótico, que o autor tem uma perspectiva positivada acerca do Império, principalmente do Segundo Reinado. Percebe-se, ainda, de forma mais clara, aquilo que se comentara antes: aqui, o pessoal e o nacional estão diretamente conectados, são duas dimensões que se completam. Nesse sentido, Magalhães de Azeredo confessa que sua admiração pelo imperador é de caráter sentimental, uma sorte de veneração; por conta disso, chega a chamar seus sentimentos - o que revela a forma como vai tratar do arranjo enfeixado em d. Pedro II - de apolíticos ou antipolíticos, porque da política, segundo ele, deveria estar "excluída, ou separada, a moral". ${ }^{153}$

Ao narrar um caso dos tempos de escola, revela, apesar de qualquer decepção pueril, algo desse deslumbramento. Em 1886, o monarca fez uma desfeita aos alunos e professores do colégio São Luís, instituição jesuíta localizada em Itu, onde o autor frequentava as primeiras letras; em visita pela cidade, o imperador prosseguiu viagem

\footnotetext{
${ }^{152}$ Carlos Magalhães de Azeredo. Memórias. Transcrição, atualização ortográfica e introdução de Afonso Arinos, filho. Rio de Janeiro: Academia Brasileira de Letras, 2003, p. 3.

${ }^{153}$ Carlos Magalhães de Azeredo. Memórias. Op. cit., p. 118. A admiração de Magalhães de Azeredo pelo monarca é tão grande, toca tanto as raias do pessoal, que é curiosíssimo notar uma passagem de suas memórias. Ao falar da primeira vez em que viu neve, fato ocorrido em Paris, no início de 1898, e de como essa visão, para quem tem espírito poético e sensibilidade aflorada, é fato marcante, ao descrever como ficou animado, tal como uma criança, o poeta se lembra de outro exemplo semelhante: ninguém menos que o próprio d. Pedro II, da sensação que aquele tivera quando, ele também, vivera sua primeira experiência com a neve. Ao comentar o caso, no fim da segunda parte de suas memórias, Azeredo puxa uma grande nota de rodapé para dizer o seguinte: "O primeiro encontro com a neve é sempre uma revelação jubilosa para quem quer que possua o sentimento de poesia. Que tal tenha sido a minha impressão, é compreensível; não podia ser outra. Mas o que se dirá de um grande monarca, maduro de idade, ilustre já na sua pátria por notáveis atos de governo, no mundo inteiro pela fama de seu vasto saber e das virtudes pessoais, e que, ao ver pela primeira vez a neve, exulta e se diverte como criança?", p. 310. A partir daí, transcreve o depoimento de um certo Aurelio Gotti, diretor das régias galerias de Florença à época do ocorrido, que narra a alegria de menino do monarca quando, nessa cidade, viu neve pela primeira vez: "Eu [Gotti] estava com ele da manhã à noite; uma das vezes que veio a Florença, era no coração do inverno; marcara-me encontro para as seis da madrugada, e devíamos visitar os arrabaldes da cidade. Às cinco veio a carruagem buscar-me; era escuro, fazia frio, e havia neve alta. Apresentei-me no Hotel da Paz, onde se alojara sua majestade, seguríssimo de que renunciaríamos ao passeio, em tal escuridão e com tão áspero tempo. Esperei por ele alguns minutos, e depois de saudá-lo respeitosamente, disse-lhe que não era oportuno sair com tão copiosa nevada. E ele, tomando-me as mãos: 'Não sabe, disse-me todo alegre, que nunca vi a neve? Vamos, vamos, que é para mim uma fortuna vê-la; vamos aonde se possa gozar dela plenamente'. Descemos, entramos na carruagem, e dei ordem ao cocheiro de conduzir-nos à esplanada Miguel Ângelo. Quando lá chegamos, e o sol nascente iluminava aquela bela extensão de neve que branqueava diante de nós, o imperador apeou, pôs-se a caminhar no meio da neve, e quedou como extasiado em frente ao magnífico panorama; não proferia uma palavra, mas aquele sentimento novo lhe transparecia dos olhos, do gesto, de toda a sua atitude; depois começou a correr, a chapinhar na neve com um rapazote; voltamos para casa molhados até os ossos (Páginas destacadas da minha vida)", p. 310.
} 
sem prestar atenção às cuidadosas homenagens que lhe haviam preparado na escola. Era gesto de desinteresse e pouco reconhecimento. O desgosto fora grande. No entanto, mesmo com a frustração, Carlos Magalhães de Azeredo, a quem mais doera a soberana falta de consideração, não hesita em, pensando melhor o caso, tentar entender a fundo a situação. Medidos bem os fatores, após a frustração inicial, resurge uma redobrada admiração por d. Pedro II. Quando descreve seus sentimentos, ao menos na linguagem, trata-se quase uma veneração de cunho transcendental, espécie de culto; superada aquela decepção, "não perdia ensejo de vê-lo, colecionava retratos seus, estudava-lhe com empenho a história"; eram, como diz, "verdadeiros sentimentos de lealismo infantil". ${ }^{154}$

Tempos depois, em 1889, quando da queda da monarquia, Magalhães de Azeredo era calouro da Faculdade de Direito de São Paulo. As primeiras notícias e telegramas, vindos do Rio de Janeiro, informando a respeito da proclamação da República, "foram recebidos com surpresa, e com certa incredulidade sobre o bom sucesso daquele movimento de tropas rebeldes". Para muitos, apesar dos desgastes do regime imperial, "a monarquia duraria pelo menos até à morte do velho soberano... como fora natural se a justiça inspirasse a História”. Em um primeiro momento, e apesar do inesperado da notícia, "os rapazes, noventa por cento deles, se entregavam a irrefreáveis explosões de júbilo, e no tumulto das ruas e das praças, efervescentes como enormes colmeias viradas de cima para baixo, se distinguiam entre os mais barulhentos e infatigáveis gritadores". Acerca dessas comemorações, Azeredo se mostrava algo consternado: "o exílio parricida, de um homem de bem, de um grande homem, que dedicara cinquenta anos da sua vida a servir a pátria, com amor e abnegação nunca excedidos, e raríssimas vezes igualados, não passava de um detalhe sem importância...". Como dito anteriormente, para nosso autor, quando é o interesse político que faz girar a

\footnotetext{
${ }^{154}$ Carlos Magalhães de Azeredo. Memórias. Op. cit., p. 53. É interessante perceber como Rodrigo Octavio também demonstrou admiração e fascínio pelo imperador; diz ele: "Foi sempre com sobressalto e exaltação patriótica que, na minha mocidade, eu via o Imperador. Ver o Imperador era, aliás, ver passar a galope o cortejo imperial [...] O cortejo passava; toda a gente, instintivamente, parava, olhava, tirava o chapéu, e, como eu, sem dúvida, se inundava, com maior ou menor intensidade, de um eflúvio estranho, sobrenatural. O Imperador! Alguma coisa de diferente, de sobre-humano, de inacessível. Geralmente, na passagem do cortejo imperial, pouco se via do Imperador; dele, sentado no fundo do carro sombrio, na disparada em que passava, quando a vista o alcançava, apenas se vislumbrava o branco das grandes barbas". Depois, à semelhança de Magalhães de Azeredo, resgata uma lembrança da escola: "Uma vez no Colégio Pedro Segundo, tinha eu 10 anos, o Imperador, de visita, entrou em nossa classe. Levantamo-nos todos e eu pude vê-lo, alto, corpulento, de casaca, com a cartola na mão. Meu coraçãozinho ficou aos saltos e eu não pude tirar meus olhos do monarca. O Imperador! [...] Essa visita ficou em meu espírito por muito tempo". Rodrigo Octavio. Minhas memórias dos outros. Primeira Série. Op. cit., pp. 29-31.
} 
roda dos acontecimentos, está excluída a moral, não há sentimento de justiça a inspirar a história. Por isso, os jovens da Faculdade de Direito festejavam, insensatamente, a queda do monarca, o exílio parricida; estavam ludibriados pelo "paroxismo das paixões, que em semelhantes conjunturas desvaira cérebros bem sólidos e fortes, quanto mais os novos e ainda débeis". No entanto, para além das paixões e ilusões, não havia muito que celebrar; Azeredo conta que, "num daqueles dias febris", um pequeno grupo de alunos cruzou, por acaso, "com um dos nossos mestres da Faculdade, o venerado Américo Brasiliense" - jurista que, após a constituinte de 1891, ocuparia cargos importantes no governo de São Paulo. Respeitosamente, lhe perguntaram, os alunos daquele grupo, a sua opinião sobre tudo o que se passava nos últimos dias; foi com certa surpresa que "de seus lábios ouvimos, pela primeira vez, aquela confissão desiludida (já tão cedo!), que centenas de vezes havia de ser proferida, no futuro, por tantos republicanos históricos: 'Esta não é a República dos nossos sonhos"”. 155

Ao contrário de grande parte de seus colegas de faculdade, Azeredo não nutria "preconceito algum antimonárquico, mesmo em relação ao Brasil"; para ele, revelando certa desilusão com os apelos transformadores, tão propalados e celebrados à época, "era de todo estranha a crença incondicional, fanática, no mito republicano, e na sua ação regeneradora dos costumes públicos, propulsora de toda a sorte de adiantamentos materiais e morais". Além disso, não lhe agradava "o caráter militarista da revolução vitoriosa"; de acordo com suas palavras, "as classes armadas tinham usurpado as prerrogativas da soberania popular, declarando agir em nome da nação, que de maneira alguma as incumbira de tomar tal iniciativa". ${ }^{156}$ Com essas opiniões, ficam claras as tendências monarquistas de Azeredo - aliás, ele terá de conviver sempre com comentários desse tipo, alguns beirando a acusação, sobremaneira após entrar, em 1895, para a carreira diplomática. Percebe-se sua patente crença no Império; este seria, em sua visão, como que um regime ideal, no qual se mantinha a unidade nacional e se evitavam mudanças abruptas e arriscadas. Em sua linha de pensamento - uma postura, inclusive,

\footnotetext{
${ }^{155}$ Carlos Magalhães de Azeredo. Memórias. Op. cit., p. 117. Novamente, é oportuno dar ouvidos a Rodrigo Octavio, que diz ter sido um exaltado nos tempos de Faculdade de Direito, mas que depois mudou suas opiniões: "Meu sentimento em relação ao Imperador tem se modificado ao longo da movimentação de minha vida. Como destas notas se percebe, eu, a princípio, o via com olhos fetichistas. O Imperador! alguma coisa que não era humana; veio depois a influência demagógica; leituras liberais, ação de companheiros, instinto natural de revolta contra o poder, fumaças de estudante. [...] Todo esse ardor, entretanto, arrefeceu com os anos, com a reflexão e, sobretudo, com os acontecimentos". Rodrigo Octavio. Minhas memórias dos outros. Primeira Série. Op. cit., p. 38.

${ }^{156}$ Carlos Magalhães de Azeredo. Memórias. Op. cit., pp. 119-121.
} 
muito parecida com a que se costumava creditar ao próprio d. Pedro II -, Azeredo demonstra somente confiar em mudanças que viessem do povo, desde que este fosse soberano e educado para tal tarefa. Como, de acordo com sua lógica, isso não se dera, como o povo restara bestializado, não espanta, quase uma consequência lógica, a rapidez com que a República deixou de ser a dos sonhos, a ligeireza com que se perderam as virtudes do novo regime. Era, portanto, um governo de paixões, não de justiça.

De acordo com Azeredo, não havia parâmetros para comparar os regimes de antes e depois de 1889; na República, nem de longe, se encontravam vultos como os dos antigos senadores e conselheiros de Estado, tais como foram (esses os nomes que cita) Zacarias, Nabuco de Araújo, Rio Branco e Silveira Martins. No entanto, não era só isso; o problema atingia dimensões mais básicas, pois, e seria esse um sinal de fraqueza moral do novo regime, "quem ousa já ter a isenção, a hombridade, com que naquele tempo se falava aos poderosos, com que, não raro até incorretamente exorbitando da justa medida, os ministros falavam ao soberano, cuja autoridade moral e prática era tão grande?" Ou seja, perdera-se a antiga atitude de coragem e abnegação que existia no Império, virtudes que eram incentivadas pelo próprio imperador. Quem, nos dias atuais, como costumava ocorrer antes, "ousa dizer a sua verdade a um presidente da República?" Mostrando suas habilidades como escritor, usando adjetivos e descrevendo situações hipotéticas, Azeredo cria imagens expressivas para dar corpo a suas questões; o caso a seguir é emblemático: “as bocas desaprenderam o 'não' ponderado e corajoso, em proveito do 'sim' permanente e incondicional, e as cabeças sabem só menear-se de cima para baixo, e não da direita para a esquerda, da esquerda para a direita". ${ }^{157}$

Dessa maneira, não é de se admirar que, nos últimos anos do século XIX quando Magalhães de Azeredo já era diplomata em Roma, cargo que ocupará por quase toda a carreira - a reputação da jovem República brasileira, nas palavras e na perspectiva do autor,

estava longe de brilhante na Europa (e menos nos Estados Unidos); a sua origem de pronunciamento militar, os disparates iniciais da sua administração, a intolerância facciosa e cega de muitos dos seus paladinos, os choques dramáticos da opressão e da anarquia, sucedendo ao governo liberal e iluminado de Dom Pedro II, popularíssimo em todos os ambientes

\footnotetext{
${ }^{157}$ Carlos Magalhães de Azeredo. Memórias. Op. cit., p. 45.
} 
cultos do mundo, faziam crer que ela precipitara o Brasil no caos do despotismo latino-americano mascarado de democracia. ${ }^{158}$

Com esses comentários iniciais, retirados das Memórias de Magalhães de Azeredo, é possível perceber algumas características que serão marcantes em sua interpretação de d. Pedro II, tais como a admiração incondicional pelo Imperador, a desconfiança com relação à República e o entrelaçamento entre memória pessoal e memória nacional. Tudo isso tecido por uma boa habilidade narrativa, o que, talvez, justifique a sua presença, quando contava apenas 25 anos, dentre os fundadores da Academia Brasileira de Letras, tendo sido o criador da cadeira de número nove. Essa participação, contudo, também sempre fora questionada, posto que, a fim de que o jovem estivesse no grupo, algumas eminentes figuras, a exemplo do barão de Rio Branco (que só entraria na ABL em 1898, como segundo ocupante da cadeira 34), foram deixadas de fora - lembre-se de um fato bastante comentado: dentre os quarenta fundadores, Azeredo foi o último a falecer, o que se deu em 1963, na cidade de Roma, quando contava 91 anos de idade. ${ }^{159}$ Especulava-se que sua aceitação em meio aos imortais só ocorrera porque Azeredo era protegido de Machado de Assis (1839-1908), com quem, desde cedo, trocava vasta correspondência. Apesar de qualquer comentário mais ou menos maldoso, não se pode ignorar que sua escrita, mesmo que constantemente pontuada por exageros de estilo, apresenta características peculiares; como diz Alexandre Eulálio (1932-1988), Azeredo era um "escritor de talento desmaiado, sobriamente fosco em verso e prosa"; além do mais, "era ele também discreto diletante da História", tanto que pertencia às fileiras do Instituto Histórico e Geográfico Brasileiro. Ainda de acordo com Eulálio, por viver em Roma, nosso autor tornou-se "colaborador providencial da Enciclopédia Italiana, que começava a ser compilada, e para a qual contribuiu com verbetes sobre Literatura e outros temas brasileiros". No entanto, um traço (outra acusação?) sempre lhe marcou a biografia: à semelhança de seu antecessor na embaixada junto à Santa Sé, o poeta Gonçalves de Magalhães (1811-1882) - escritor escolhido, não sem motivo, para ser o patrono da cadeira nove da $\mathrm{ABL}^{160}$-, Azeredo, “cada vez mais imerso no absorvente mundo

\footnotetext{
${ }^{158}$ Carlos Magalhães de Azeredo. Memórias. Op. cit., p. 249.

${ }^{159}$ As informações biográficas acerca de Carlos Magalhães de Azeredo foram retiradas do site da Academia Brasileira de Letras (www.academia.org.br).

${ }^{160}$ A escolha dos patronos, na ABL, atendia à necessidade, fundamental em uma instituição como essa, de estabelecer uma tradição e um passado oficial da literatura brasileira. Como ressalta Alessandra El Far, a Academia Brasileira não se responsabilizava somente por estabelecer normas para a língua portuguesa, tal
} 
romano, fora progressivamente perdendo contato com a vida cultural do país de origem, apesar dos naturais esforços a fim de se manter informado do que ali acontecia, membro fundador que era afinal da Academia Brasileira". ${ }^{161}$

Sobre esse distanciamento do Brasil, ressalte-se que, longe de ser um detalhe sem maior importância, é bastante revelador. O frequente afastamento do país natal, de certa forma, molda o entendimento de Azeredo acerca da história do Brasil e, principalmente, a respeito de d. Pedro II. Por exemplo, ao tratar, em seu livro sobre o monarca, das viagens do imperador e da impressão que ele despertava por onde passava, sendo, inclusive, chamado rei itinerante, Azeredo aborda uma questão interessante note-se que há, nesta passagem, ecos das ideias e da linguagem de seu patrono Gonçalves de Magalhães: “a personalidade intelectual do imperador, não [era] um fenômeno de exotismo, como na Europa criam muitos, na ignorância de nossas coisas então ainda mais geral que hoje, mas um genuíno produto da civilização brasileira". ${ }^{162}$ O monarca era, portanto, em si mesmo, o mais bem acabado exemplo da civilização brasileira; ou seja, um caso notável de fusão entre cultura externa e especificidade interna, o que resultava em uma manifestação civilizacional de rica originalidade. Conseguia formular com mais clareza, essa imagem da particularidade nacional, quem enxergava as coisas de fora, quem se preocupava com a visão externa a respeito do Brasil. Dessa maneira, a um só tempo, o imperador - da mesma forma que o próprio Magalhães e Azeredo - conseguia ser cosmopolita e nacionalista. Como diz nosso autor:

Cosmopolita pela largueza e pela maleabilidade do espírito, ele foi nacionalista pelo fervor do sentimento cívico, e pela intransigência em tudo que concernia à honra, à dignidade, ao destino do país. Mais; foi um dos criadores do nacionalismo brasileiro, pela crença inabalável na missão histórica da sua jovem pátria, pelo seu empenho na consolidação da unidade territorial, pela sua vigilância constante sobre a observância das leis, a honestidade da administração e da justiça pública, pela sua contribuição

como fazia a similar francesa, o grande modelo inspirador; aqui, "ao ordenar o passado, que até então se mostrava disperso, os acadêmicos estabeleceriam uma história oficial, instituiriam mitos e recontariam uma memória literária, mostrando, por fim, a existência de uma tradição nas letras brasileiras. [...] Para conquistar o respeito caro a toda corporação desse caráter, era preciso construir um passado que a sustentasse, por mais que este fosse forjado e selecionado. $\mathrm{Na}$ verdade, a sugestão de acrescentar aos números das cadeiras os nomes de seus patronos partiu de Nabuco, a quem repugnava a ideia de 'surgir a Academia sem uma raiz em nosso passado'. Na falta de antepassados, a única solução seria criá-los. Como disse Nabuco em carta a Machado de Assis: 'Os chins enobreceram os antepassados, nós fizemos mais porque os criamos"”. Alessandra El Far. A encenação da imortalidade. Rio de Janeiro: Editora FGV, 2000 , p. 60 .

${ }^{161}$ Alexandre Eulálio. "Prefácio". In: Carlos Magalhães de Azeredo. Memórias. Op. cit., p. II.

162 Carlos Magalhães de Azeredo. Dom Pedro II. Traços de sua physionomia moral. Rio de Janeiro: Álvaro Pinto, editor, 1923, p. 39. 
incessante pelo progresso moral, intelectual e material do povo confiado à sua guarda, pela altivez inquebrantável, ainda que pacífica da sua política internacional. ${ }^{163}$

Uma pessoa, por conseguinte, ímpar, que deveria ser cultuada e rememorada como um grande exemplo nacional. E foi exatamente isso que Magalhães de Azeredo fez; em 1925, por ocasião do centenário de nascimento do imperador, escreveu o livro Dom Pedro II. Traços de sua fisionomia moral, obra da qual foi extraída a citação acima. Logo na nota introdutória, está esclarecido que se trata de um livro com um fim específico; qual seja, o de divulgar o monarca, para o público que for, seja estrangeiro ou nacional: "este estudo apareceu em francês na Revue de l'Amerique Latine, de Paris e em italiano na Nuova Antologia, de Roma. Escrito para leitores estrangeiros, não julgo inútil, entretanto, oferecê-lo, no original português, ao público do meu país". ${ }^{164}$ A partir dessa informação, ganha mais sentido o espanto dos estrangeiros, relatado no final do livro, com o fato dos brasileiros terem destronado d. Pedro II; alguns "intelectuais" europeus, confusos, questionavam por que, afinal de contas, se tinha deixado ir "um imperador tão bom e sábio?" Uma pergunta que Azeredo diz ter ouvido até mesmo da boca de vultos importantes; "um deles chegou a acrescentar: 'Pois nós, se cá o tivéssemos, e ele quisesse deixar-nos, o faríamos prisioneiro para que não se pudesse ir embora!". ${ }^{165}$ Levado isso em conta, fica perceptível que perpassa a obra, da introdução ao fim, filtrado pelo olhar estrangeiro e através da combinação produtiva de políticos e apolíticos, certo sentimento de que a deposição de d. Pedro II fora um equívoco; logo, era preciso encontrar a melhor forma de lidar com sua memória, de saber entender o seu legado, de colocar essa fisionomia moral no lugar em que merecia.

No início de seu livro - ressalte-se que não se trata mais das memórias, e sim de um perfil do imperador -, Magalhães de Azeredo dá o tom pessoal do texto, a memória surge atrelada à lembrança particular; segundo suas palavras, "a figura de Dom Pedro II prende-se às reminiscências de minha infância. Eu nasci numa família conservadora, em que o sentimento monárquico era muito acentuado". ${ }^{166}$ Isso não impediu, contudo, que ele, assim como muitos outros jovens de sua época, uma tendência comum à "precocidade tropical" (expressão que vem bem a calhar num livro feito, inicialmente, para estrangeiros), fosse inclinado ao pensamento liberal e ao abolicionismo. Sua

\footnotetext{
${ }^{163}$ Carlos Magalhães de Azeredo. Dom Pedro II. Traços de sua physionomia moral. Op. cit., pp. 71-72.

${ }^{164}$ Carlos Magalhães de Azeredo. Dom Pedro II. Traços de sua physionomia moral. Op. cit., p. 7.

${ }^{165}$ Carlos Magalhães de Azeredo. Dom Pedro II. Traços de sua physionomia moral. Op. cit., p. 97.

${ }^{166}$ Carlos Magalhães de Azeredo. Dom Pedro II. Traços de sua physionomia moral. Op. cit., p. 9.
} 
geração era, conforme relata, fascinada pelo "prestígio de Joaquim Nabuco", pela sua verve de orador e batalhador pelo fim da escravidão. Entretanto, essa tendência de impulso tropical não fora suficiente para ofuscar sua fascinação de menino pela "grande e empolgante personalidade" do imperador, para obliterar "um sentimento de veneração entusiástica”. A transcendência do monarca, portanto, ia além dos fervores juvenis e das paixões mundanas. Tanto é que a própria constituição física do imperador tocava fundo na imaginação do menino; era uma "fisionomia majestosa", "presença genuinamente imperial", algo que poucos tinham ou podiam ter. Azeredo faz questão de, nas páginas iniciais, descrever, com lances poéticos e acentuado detalhismo, o ídolo de sua veneração:

Dom Pedro II era um belo homem, de alta estatura, compleição robusta, e admirável porte. A cabeça pujante pousava com energia tranquila sobre os largos ombros. Os cabelos e as barbas fluentes, cedo encanecidas, de uma finura de seda e de uma brancura de prata, se harmonizavam com a tez alta, levemente rósea. A boca, de um desenho firme e delicado, era relativa de bondade, e o queixo, assaz saliente, denunciava uma vontade tenaz. Sob a fronte ampla, elevada, um pouco saliente também, os olhos, muito azuis, brilhavam serenos, um tanto frios; fitavam o interlocutor decididamente, como buscando penetrar-lhe as paixões e os interesses reais atrás dos meandros da linguagem áulica; mas no silêncio facilmente se velavam de uma expressão pensativa, e como alheia ao ambiente. A voz, apenas, desorientava um instante quem a ouvia pela primeira vez; era delgada, quase feminina; mas o tom seguro, e a rapidez da dicção, corrigiam de pronto essa inferioridade. ${ }^{167}$

Nos próprios traços físicos do corpo, revela-se uma figura de elevadas qualidades morais. Um ser que inspira respeito e admiração, no qual se percebia serenidade, decisão e segurança. Segundo Azeredo, com a maturidade, seus sentimentos com relação ao monarca deixariam de ser impressões de menino e ganharam mais embasamento; com "o estudo mais raciocinado da história nacional", iluminaram-se definitivamente seus "fundamentos morais". Não era mais somente a admiração pelo porte imperial, algo que advinha, a princípio, de características físicas; agora, esse ser ganhava largueza e profundidade, era sustentado por traços de personalidade e pela história da formação da nacionalidade. O passado monárquico, portanto, materializado na própria constituição do imperador, fora de virtudes e glórias: "no primeiro plano do vasto panorama, erguia-se, firme como sempre, e incensado pelo meu respeito, pela minha gratidão de brasileiro, o homem que, por mais de meio século, merecera simbolizar o Brasil perante o mundo". É um livro, este sobre a fisionomia moral do

\footnotetext{
${ }^{167}$ Carlos Magalhães de Azeredo. Dom Pedro II. Traços de sua physionomia moral. Op. cit., pp. 13-14.
} 
imperador, no qual o sentimento do autor para com d. Pedro II - e lembre-se de suas concepções acerca de política e moral - quase escapa aos limites da prática e da atuação enquanto governante; é uma admiração que "paira nos cumes da história, naquelas regiões supremas e eternas, onde misteriosas se tornam as relações do humano com o divino". Por conta disso, fica mais saliente aquela nota de ressentimento que perpassa todo o texto. Essa é uma forma, mesmo que de maneira enviesada, de lançar dúvidas sobre a República brasileira; uma maneira, em suma, de questionar a fisionomia moral do regime iniciado em 1889. Afinal, aquele que fora destronado para o estabelecimento da nova ordem "era o mais democrático príncipe de sua época, e tal como, por ventura, só na América poderia ter nascido". Era, assim, um governante único, formado através da peculiaridade do contexto no qual se inseria; tudo isso contribuía, sobremaneira, para se lamentar a perda de tão importante vulto. Magalhães de Azeredo diz - em uma passagem digna de figurar no livro de Luís Martins, O patriarca e o bacharel - que "a tragédia íntima que amargurou a velhice do soberano, e lhe apressou provavelmente a morte", acrescentou à perda do monarca "a emoção de uma imensa piedade, da piedade que despertam os sofrimentos das almas superiores, e que a elas nos une em uma vibração de heroico misticismo". ${ }^{168}$ Este o homem do qual tínhamos aberto mão; dele era preciso manter viva a memória.

A partir de observações como essa, Azeredo se propõe pensar qual seria o significado da monarquia para o imperador. Diante de uma fisionomia moral como esta, diz que seria algo como uma concepção próxima da magistratura, considerava-se o "primeiro cidadão", o "magistrado supremo". Tratava-se, contudo, por conta de governar uma nação dividida entre dois cenários distintos, de uma "magistratura, simultaneamente, constitucional e paternal"; cabia a ele dirigir um país, "cujas altas camadas sociais", por um lado, "tinham assimilado com diligência maravilhosa a cultura científica, artística, política, da velha Europa”, mas, por outro, “onde a massa imensa da população, esparsa em imenso território, não possuía ainda, nem possuiria por largo período, a capacidade de inspirar, de fiscalizar, mesmo de entender, o complicado jogo dos partidos, que ficticiamente em seu nome, se revezavam no poder". A função do imperador, assim, era extremamente complexa; note-se que, ao tratar desse assunto, Azeredo pensa em termos de uma função dupla:

\footnotetext{
${ }^{168}$ Carlos Magalhães de Azeredo. Dom Pedro II. Traços de sua physionomia moral. Op. cit., pp. 9-12.
} 
a Dom Pedro II tocava por necessidade histórica o duplo papel de chefe de uma elite muito adiantada, e de 'patriarca' de uma gente quase primitiva, que lhe cumpria proteger precisamente contra a desenvoltura dos politicamente profissionais, e encaminhar, através dos colaboradores constitucionais do trono, para destino digno da grande nacionalidade ainda em gérmen. ${ }^{169}$

Era preciso, então, em parte, gerir os interesses da elite, coordenar a ficção do revezamento entre partidos e, em outra, proteger os desvalidos que estavam à mercê dos desmandos e "desenvoltura" daqueles que participavam do jogo político. Com isso, conseguia, superando as dificuldades, manter estável e sempre viva a nacionalidade. Somente um imperador moral e equilibrado, cosmopolita e nacionalista, podia cumprir tal tarefa, ser magistrado e patriarca. Porém, o êxito não dependia só dele; para Azeredo, a fraqueza de nossa vida nacional estava - motivo muito comentado pelos historiadores e intérpretes de então - na falta de uma opinião pública organizada e representativa. Decorrência disso, o imperador, imbuído do poder pessoal, ficava preso numa armadilha, entre uma elite avançada e uma população dispersa e mal formada. Dessa forma, e para desgosto de quem estivesse na oposição, d. Pedro II, por vezes, tinha de agir, baseado nas prerrogativas que lhe eram garantidas pela Constituição, impetuosamente na vida política. Por se tratar de uma "fisionomia moral" das mais elevadas, tais ações nunca são criticadas pelo autor; são, isso sim, sempre tomadas enquanto exemplares. Nessa leitura, o imperador, diante de tal povo criança e da elite interesseira, deveria assumir responsabilidades prementes, não importando se, para isso, se colocasse além do jogo político. Assim, eram “a 'idade', e, por ventura, a própria fisionomia orgânica do povo", que "impediam que o monarca se enclausurasse nos limites quase meramente 'registrativos' da autoridade real na Inglaterra". No Brasil, ao contrário, "tornava-se inevitável que o Estado se fizesse sentir, como propulsor, temperador, ou corretor, mais que em países antigos, nas grandes correntes da vida pública”. Dessa maneira, mesmo que d. Pedro II não pudesse ou não desejasse ser uma espécie de Luís XIV, as condições nacionais acabaram forçando-lhe a ser algo parecido: "sua permanência no trono através de tantas gerações de políticos, em contraste com a ação intermitente dos ministérios e dos partidos trazia por efeito necessário que o Estado fosse ele, mais que todos". ${ }^{170} \mathrm{O}$ que se revela, aqui, é uma maneira positiva de tecer a memória acerca do arranjo de d. Pedro II. Produtividade e risco estão bem nuançados, pois o monarca, pai sábio de um povo criança a ser tutelado e coordenador

\footnotetext{
${ }^{169}$ Carlos Magalhães de Azeredo. Dom Pedro II. Traços de sua physionomia moral. Op. cit., pp. 17-18.

${ }^{170}$ Carlos Magalhães de Azeredo. Dom Pedro II. Traços de sua physionomia moral. Op. cit., p. 20.
} 
dos interesses da elite a partir da sua postura impoluta, o patriarca e o magistrado, por vezes, tinha de intervir com rigor na vida política; no entanto, como o eixo da argumentação de Azeredo é a fisionomia moral do personagem, como o foco está sobre sua transcendência, tais intervenções são sempre legitimadas e entendidas como necessárias. São atitudes de um monarca que paira acima de seus concorrentes no jogo político.

Magalhães de Azeredo, a partir dessa particularidade que cerca d. Pedro II - ser imperador de uma nação bastante jovem e precisar intervir constantemente no jogo político -, em diversos momentos chama atenção para a unicidade desse rei americano. Ele é a combinação de fatores díspares, de diferenças que se fundem para formar uma curiosa originalidade aristocrático-burguesa: "conquanto descendente dos Bragança, dos Habsburgos, dos Bourbons, e aparentado com quase todas as casas reinantes da Europa, havia nele, como imperador do Brasil, algo de self-made man". ${ }^{171}$ Trata-se de um rei que, a um só tempo, era fruto da tradição e da revolução. Azeredo, dessa forma, vai equilibrando duplicidades: rei e burguês, monarca absoluto e fruto de uma revolução, fusão entre Europa e América, coordenador da elite e protetor do povo. Um imperador, portanto, adequado a uma monarquia surgida de uma colônia, um reino do Novo Mundo; governante ideal para um Estado ainda em formação, cujo sentimento de nacionalidade era incerto e precisava ser gerido com cautela e equilíbrio. Um homem, em suma, "honesto, clemente, generoso e intrépido, um defensor estrênuo da lei, do direito, da liberdade, um filósofo coroado que reconhecia, ao lado e acima da soberania dos reis, a transcendente soberania do espírito". ${ }^{172}$

Mesmo após o exílio, o imperador continuaria comprovando a grandeza moral de seu espírito. Nenhuma grande mostra de insatisfação; "nada do rancor ou do profético reproche de Cipião: 'Ingrata pátria, não possuirás meus ossos!' - um 'pugilo' de terra do Brasil, como penhor de futura união com ela. E assim foi”. Aqui, Azeredo retoma, de forma bastante sutil, o tema do retorno do imperador, dando-lhe quase um sentido profético. Era como um reencontro traçado pela história; esta, finalmente, estava sendo guiada pela justiça. Quando da chegada dos despojos,

uma apoteose de veneração e piedade acompanhou o regresso do augusto monarca ao pátrio solo. No esquife ia apenas a cansada veste mortal; mas, certo, o nobre espírito imperecível pairava, confortado, sobre aquela solene

\footnotetext{
${ }^{171}$ Carlos Magalhães de Azeredo. Dom Pedro II. Traços de sua physionomia moral. Op. cit., p. 21.

${ }^{172}$ Carlos Magalhães de Azeredo. Dom Pedro II. Traços de sua physionomia moral. Op. cit., p. 26.
} 
manifestação de justiça, que reconciliava para sempre o passado e o presente.

Os traços morais de d. Pedro II, assim, ao contrário dos motivos de sua deposição, pertenciam à memória pátria, mereciam ser celebrados, era preciso fazer-lhes justiça; "foram um patrimônio do qual o Brasil tem o direito de se orgulhar". São qualidades que só a "má fé lhe poderia questionar". ${ }^{173}$

$\mathrm{O}$ veredito do autor parece bloquear quaisquer opiniões em contrário; em face de uma superioridade tão completa, só podia se opor a mesquinhez de indivíduos menos dotados de espírito moral. É fundamental notar como, dentro da lógica interna do livro, há um crescente: a parte inicial é dedicada a exaltar, de maneira geral, o monarca, sempre o opondo, mesmo que de maneira enviesada, ao regime republicano; depois, na parte final, aborda-se o retorno dos restos mortais, justificando, assim, a importância única deste personagem. Parte-se do gesto injusto para se atingir a justiça maior da história. Dessa maneira, através de um jogo bem elaborado entre subjetividade e objetividade, celebra-se a memória e cultua-se o passado. A obra, com essa dinâmica interna, fecha seu próprio ciclo de sentido e legitimidade; com as duas pontas bem definidas, é possível preenchê-la, através de uma narrativa bem elaborada, da forma que for mais de acordo com a proposta. O resultado é positivo; Azeredo tece a imagem de um monarca desinteressado, que "não fez política dinástica", não precisou convocar, em seu auxílio, "as classes conservadoras mais poderosas, nem o exército, que aliás nunca desdenhou nem prejudicou, como foi falsamente insinuados"; também não precisou do auxílio do clero, "que antes irritou e desgostou pela sua atitude na chamada questão dos bispos", nem da "aristocracia agrária, cujas pretensões, aliás notoriamente opostas à justiça e ao sentimento cristão, contrariou abertamente como patrocinador - que foi entre os primeiros e mais resolutos - da emancipação dos escravos". ${ }^{174}$

D. Pedro II, para Azeredo, foi, definitivamente, o monarca que o Brasil precisava. E ele cumpriu com sua tarefa. Não só isso; foi um exemplo, um modelo de cujo legado a República deveria se esforçar por ser digna. A monarquia brasileira fora "fruto de verdadeiro compromisso entre o princípio dinástico e o espírito democrático, 'democracia coroada', disse o general Mitre”; um compromisso que era garantido, acima de tudo, pelo "prestígio da "virtude"” do monarca, único sujeito que podia

\footnotetext{
${ }^{173}$ Carlos Magalhães de Azeredo. Dom Pedro II. Traços de sua physionomia moral. Op. cit., p. 35 e p. 37.

${ }^{174}$ Carlos Magalhães de Azeredo. Dom Pedro II. Traços de sua physionomia moral. Op. cit., pp. 53-54.
} 
"garantir-lhe, como lhe garantiu, meio século de reinado, e o amor do seu povo, reagindo contra a fúria iconoclasta das democracias, implacáveis e insaciáveis reencarnações de Saturno". Para o autor, além do mais, era preciso ressaltar que a República brasileira, inegavelmente, trazia características do regime imperial; o "caráter conservador e temperado" de nossas instituições, assim como a incompatibilidade com "as incandescências e iniquidades do histerismo jacobino", eram sinais disso. Essa é, portanto, uma República privilegiada, pois contou, antes de si, com "meio século de patriotismo intemerato, de culto da lei acima de tudo, foi uma escola moral magnífica". ${ }^{175}$ Dessa maneira, apesar das divergências de fundo, a República não deveria temer o Império; nada havia a fazer a não relembrá-lo e tomá-lo como exemplo. Assim, não havia riscos em cultuar a memória de um grande vulto, tal como fora o do monarca. Tratava-se, em verdade, de uma mostra "da estima e da admiração por Dom Pedro II", algo que deveria ser feito por todos os brasileiros, inclusive, ou principalmente, por "aqueles que tudo subordinam ao interesse político"; estes, sem maiores preocupações, "podem aceitar com serenidade a sua glória, cujo fulgor se reflete na fronte mesmo da pátria". D. Pedro não era ameaça à paz nem à solidez da República; "a monarquia pertence definitivamente ao passado". ${ }^{176} \mathrm{O}$ que resta, acima de tudo, lá nos cumes da história, no reino da moral, não da política, é o homem. Tal com Napoleão fez com Goethe; da maneira como Pôncio Pilatos fez com Jesus; Magalhães de Azeredo, acreditando que nenhuma implicação de maior gravidade há nisso, apresenta, para estrangeiros e brasileiros, o homem. Nada havia a temer.

\footnotetext{
${ }^{175}$ Carlos Magalhães de Azeredo. Dom Pedro II. Traços de sua physionomia moral. Op. cit., pp. 79-80.

${ }^{176}$ Carlos Magalhães de Azeredo. Dom Pedro II. Traços de sua physionomia moral. Op. cit., p. 102.
} 


\section{1. 2. Pedro Calmon: D. Pedro II, entre dois tempos e duas edições}

"A república honrou o Imperador; desde a Constituição de 1891, em que mandou dar-lhe a pensão que assegurasse subsistência decente no exílio, até o retorno piedoso das cinzas, em 1921. Fez-se justa, depois que se tornou indiscutível. Ninguém vai a Petrópolis, sem visitar, na catedral, a capela que lhe exibe o mausoléu. Não é um mito, é um homem. [...] É uma figura que passa, ou antes, não passou. Porque se sobrepôs ao tempo; e dele falamos hoje como se fosse de ontem a sua presença. Este livro é antes de tudo essa presença".

Pedro Calmon, na introdução à edição de 1975 de $A$ vida de d. Pedro II, o rei filósofo

Em 1938, o historiador Pedro Calmon publicou a biografia O rei filósofo: a vida de D. Pedro II, cujo título, por si só, ao juntar política e ciência, já deixa bem a entender qual o tom empregado e sob quais aspectos o imperador será abordado. Tal livro apresenta características formais interessantes que, como não poderiam deixar de ser, casam-se perfeitamente com a temática trabalhada; além do mais, note-se que foi publicado em um período importante da retomada memorialística de d. Pedro II, o ano anterior à inauguração do mausoléu de Petrópolis. Antes, porém, de adentrar os meandros e especificidades, é preciso tratar do autor; Pedro Calmon nasceu em Amargosa, Bahia, a 23 de dezembro de 1902. Sua formação e início da produção bibliográfica foram rápidas: em 1920, adentrou na Faculdade de Direito da Bahia; já em 1922, a pedido de seu padrinho, Miguel Calmon (1879-1935), foi para o Rio de Janeiro secretariar a Comissão Promotora do Centenário da Independência. Nessa cidade completaria, dois anos depois, seus estudos superiores. Sempre ligado à produção historiográfica, habilitou-se para trabalhar "como conservador do Museu Histórico Nacional, tendo sido um dos mais fiéis colaboradores de Gustavo Barroso". Nessa mesma instituição criou, em 1932, “a cadeira de História da Civilização Brasileira, para a qual escreveu um livro com o mesmo título. Em 1935, regeu essa disciplina na Universidade do Distrito Federal". ${ }^{177}$ Foi, também, livre-docente em Direito Público Constitucional na Faculdade Nacional de Direito da Universidade do Brasil e, durante dez anos, entre 1938 e 1948, diretor da mesma instituição. Posteriormente, até 1966, seria reitor da mesma Universidade. Desde 1955, era catedrático de História do Brasil no Colégio Pedro II. Exerceu, ainda, atividades na vida pública e política; foi deputado

\footnotetext{
${ }^{177}$ Regina Abreu. A fabricação do imortal. Op. cit., p. 29.
} 
estadual da Bahia e deputado federal. Entre 1950 e 1951, no governo do presidente Dutra, foi ministro da Educação e Saúde. Era membro da Sociedade de Geografia do Rio de Janeiro e dos Institutos Históricos de vários estados brasileiros, assim como de instituições internacionais afins. Desde 1936, era o terceiro ocupante, na Academia Brasileira de Letras, da cadeira 16, tendo sido recebido pelo acadêmico, e antigo chefe, Gustavo Barroso. Faleceu na cidade do Rio de Janeiro, em 17 de junho de 1985, aos 82 anos. $^{178}$

Como se percebe, Pedro Calmon era uma pessoa muito bem relacionada nos meios intelectuais, transitando, ao longo de sua vida, entre várias instituições culturais e de ensino. Assim, não espanta que, pensando no teor dessas instituições, na biografia de sua autoria venha à tona um $\mathrm{d}$. Pedro II intelectualizado, ligado à cultura e ao saber, um efetivo rei filósofo. Interessante perceber, também, como o autor, apesar de falar de uma posição bastante perceptível, defende uma história que não seja mera apologia e nem influenciada por fatores e interesses políticos; ao longo de seu texto, pretende fazer não um panegírico ou um ataque, mas uma busca pela justiça histórica e por formas definitivas de entendimento. $\mathrm{Na}$ introdução à primeira edição, de 1938 , vem escrito o seguinte, o que revela uma concepção de história que visa a imparcialidade e a escrita narrativa (revela, também, algumas ideias afins com as de Magalhães de Azeredo): “Quando a arte de narrar se desprendesse da influência política - insensível e tenaz que sutilmente lhe corrompe os intuitos, a luz da História, derramando-se pelos panoramas do passado, seria também o bom clarão da verdade". É isso que vai buscar com seu livro, um "clarão da verdade", uma revelação que surja da própria "arte de narrar”. Essa, aliás, é uma informação importante: o eminente caráter narrativo do texto; tanto o é que, em vários momentos, chega a elaborar diálogos entre personagens, o que lhe permite interpretar sentimentos, penetrar subjetividades e lançar vários subentendidos pelo caminho. Ou seja, sua proposta se realiza através da fusão entre forma e tema, de maneira a construir um painel acerca da vida do segundo monarca. Retomando o texto da introdução, entende-se a profundidade dessa proposta, pois biografar d. Pedro II era acender o "clarão da verdade" sobre "homens e coisas das origens nacionais"; à falta de fisionomias modelares e grandes líderes nacionais, era preciso retomar - o que revela, algo que se queria evitar, uma "influência política" do

\footnotetext{
${ }^{178}$ Além do livro de Regina Abreu, as informações biográficas acerca de Pedro Calmon foram retiradas do site da Academia Brasileira de Letras (www.academia.org.br).
} 
autor - os antigos "índices biográficos, as forças condutoras do país, vidas insignes que se não separam mais de sua evolução, as almas-sínteses. Nesta situação está d. Pedro II". 179

Nesse sentido, perceba-se que nem toda vida era insigne, nem todo vulto, um modelo a ser exaltado. Por exemplo, a seguinte colocação: “em 14 de junho de 41 faleceu José de Resende Costa, o último sobrevivente da Inconfidência Mineira. O necrológio do Instituto Histórico habilmente esqueceu esse título: por que falar em Tiradentes, na época de Pedro II?". ${ }^{180}$ Ou seja, para que falar - e novamente surgem as "influências políticas" - de tormentas em tempos de paz, de crise em uma era de glórias, de vultos menos insignes na época do grande imperador? A memória a ser cultuada, e cabia ao Instituto Histórico determinar quem deve sobreviver ao passar do tempo, é a da grandeza do rei filósofo, que fazia sombra a todos os seus rivais. Na relação entre memória e esquecimento, deveria se sobrepor a glória nacional.

A passagem anterior revela outro dado importante: a memória de d. Pedro II sempre é comparada à de outros personagens. $\mathrm{Na}$ biografia feita por Calmon, o monarca, por exemplo, algumas vezes é entendido em paralelo com seu avô e pai; logo na introdução, aos três, o autor chama "reis magos do Brasil". D. João VI foi o Rei do Brasil; Pedro I, o cavalheiro; Pedro II, o filósofo. Em momentos como a questão Christie ou a Guerra do Paraguai, encerrou-se, no espírito do segundo imperador, o ciclo de d. João VI e iniciou-se o de d. Pedro I. Depois, com o amadurecimento, se afirmariam seus traços próprios, notáveis na figura do monarca-cidadão, de trajes civis e cultura vasta. Era, portanto, um rei que, acima dos demais, se afirmava por sua sabedoria e moderação; não precisava expor seu grande poder, nem utilizar da força. Bastava por si só. Nesse sentido, é possível perceber como Pedro Calmon, ao longo de seu texto, revela sempre o lado transcendente do arranjo de d. Pedro II, o seu lado filósofo, sobrepondo isso ao aspecto imanente e político de seu regime.

Ao tratar da infância do monarca, Pedro Calmon ressalta, logo de início, a excepcionalidade do imperador; antes dos seis anos, ele "era uma entidade política. Juntava ao nome um algarismo: Pedro II". Assim, o jovem, “um menino-símbolo", era ele próprio uma representação da monarquia; precisava, portanto, ser formado da melhor maneira possível, a fim de cumprir bem com as demandas do destino. Cercado

\footnotetext{
${ }^{179}$ Pedro Calmon. O rei filósofo: a vida de D. Pedro II. Rio de Janeiro: Companhia Editora Nacional, 1938 (Coleção Brasiliana, vol. 120), pp. 13-14.

${ }^{180}$ Pedro Calmon. O rei filósofo: a vida de D. Pedro II. Op. cit., p. 67.
} 
por iminentes pessoas, foi educado, desde cedo, para ser um monarca; era imprescindível - e note-se, nessa passagem, como a transcendência mística do monarca vai se fundindo à transcendência garantida pelo saber - "que estudasse, que se convencesse de sua posição, que fosse como os príncipes excelsos, justos como santos, instruídos como sábios, de halo místico, sobre a coroa...". ${ }^{181}$ De acordo com Calmon, essa missão educativa foi favorecida pela deposição de d. Pedro I, a qual, tão sugestivamente, chama de "revolução brasileira"; essa revolução não destronou o jovem herdeiro, mas o legou, de certa maneira, ao esquecimento, dando-lhe condições de se preparar com calma e dedicação. Seria essa outra forma de banimento que, apesar de garantir, por um lado, muitas infelicidades e o sacrifício da infância - "a primeira pessoa do Império era também a mais infeliz", pois, quantas vezes "não invejou a selvagem independência dos meninos pobres de sua idade, que se rebolavam, como pequenos potros bravos, no gramado verde feito para rolarem crianças e saltitarem pássaros"182 -, assegurava, por outro, o recolhimento e a atenção necessária aos estudos; contribuía, assim, para a excepcionalidade do monarca. Percebe-se, no que diz respeito a esse assunto, um pouco da arte narrativa do autor; ao tratar da infância de d. Pedro II, consegue criar, de maneira hábil, imagens impressionistas e despertar compaixão pelo biografado, uma criança reclusa, sem amigos e folguedos. Era um "César minúsculo"; dentro em pouco, seria coroado imperador, "um imperador de festa procissão do Santíssimo: 14 anos!". 183

Na lógica narrativa de Pedro Calmon, portanto, essa infância fora, dentre outras coisas, fundamental para d. Pedro II desenvolver e firmar noções essenciais para sua vida, assim como para seu regime. Era um governante que sabia a exata dimensão do sacrifício ao qual tinha de se submeter; "foi a sua ideia imutável: a de quem cumpre a obrigação, e não vê heroísmo nisso. Limitava-se a exigir dos outros igual honestidade". Era, assim, um ser disposto a sacrifícios; a negar seu gozo próprio em nome do bem nacional. "Nascera para servir" e "não se rebelava contra isso". Jamais denunciava, em seus gestos, qualquer insatisfação ou desgosto; "silenciava as impaciências com um pudor invencível. Os lábios não o traíram”. Seu consolo, quando a fadiga das obrigações começava a pesar-lhe demais, quando o destino passava quase a sufocá-lo,

\footnotetext{
${ }^{181}$ Pedro Calmon. O rei filósofo: a vida de D. Pedro II. Op. cit., pp. 24-26.

${ }^{182}$ Pedro Calmon. O rei filósofo: a vida de D. Pedro II. Op. cit., p. 30.

${ }^{183}$ Pedro Calmon. O rei filósofo: a vida de D. Pedro II. Op. cit., p. 64.
} 
era "sonhar com um retiro, onde o tempo corresse discretamente, entre livros...". ${ }^{184}$ Dedicação, sacrifício e recolhimento em meio a livros, essas as características essenciais desse rei filósofo. Um exemplo, sem margem para dúvidas, a ser exaltado: afastado das intrigas e interesses políticas, era um vulto insigne da nação.

Dessa forma, muito além de um tema menor na biografia, ou de ser entendido como curioso exercício diletante e exibicionista, o "enciclopedismo", ampla rede que o monarca "atirava a todas as manifestações culturais", era um traço necessário e fundamental; além de lhe resolver dilemas pessoais e funcionar como válvula de escape particular, "atendia-lhe à índole liberal, à neutralidade que se impusera, em livros de todo gênero: uns áridos e práticos - das descobertas do século, aplicadas ao progresso da nação - outros mimosos e sentidos, seus poetas, seus romancistas, seus ensaístas prediletos". Pedro Calmon comenta que uma imagem negativa sobre esse excesso de ciência existia já nos tempos do Segundo Reinado; outrora, se duvidava "das imperiais leituras", feitas com suposto fingimento e superficialidade; além disso, valia-se o imperador do "privilégio de perguntar o que queria, sem que lhe perguntassem, a ele...". ${ }^{185}$ Segundo Calmon, entretanto, d. Pedro II fazia de seus conhecimentos - o que revela o efeito político do arranjo entre rei e filósofo - um meio de afirmar autoridade e neutralidade face aos ministros, evidenciar superioridade intelectual e colocar os outros sempre um nível abaixo. Precisava situar-se, mesmo que de forma dissimulada, como a autoridade máxima do país. Logo, não há maneira de entendê-lo, por completo, sem relevar essa busca insaciável por saber; era prazer, informação e, também, uma ferramenta política. Por isso, esmerava-se em ser um sábio e um exemplo: “onde houvesse concurso de professores, e pudesse ir, lá o encontrariam, na mesa, pincenê acavalado no nariz fino, ouvindo a arguição". Ocupava-se, além do mais, da papelada que lhe era constantemente enviada pelos ministros, referente aos concursos realizados no país. Seu rigor era, na perspectiva de Calmon, uma característica positiva, e não atitude mesquinha de um monarca entediado. Nesse sentido, note-se a sutileza da seguinte observação:

A política, era deles [dos ministros]; o professorado, do monarca. Compartimentos estanques; magistraturas apartadas. Insensivelmente tornara-se o grande Censor. Mestre-escola do Império. Inspetor de ensino. O policiador da moralidade. Instrução, Justiça, Senado... .

\footnotetext{
${ }^{184}$ Pedro Calmon. O rei filósofo: a vida de D. Pedro II. Op. cit., p.94.

${ }^{185}$ Pedro Calmon. O rei filósofo: a vida de D. Pedro II. Op. cit., pp. 118-119.
} 
Os compartimentos, entretanto, não são tão estanques assim como queria o autor, pois do campo estrito da instrução nacional, a supervisão de d. Pedro II, insensivelmente, se transformava na do grande Censor, policiador não só da educação, como também da justiça e do senado. Ou seja, o monarca estava, ao menos moral e intelectualmente, acima dos demais políticos; era capaz de julgá-los, censurá-los e condená-los. Calmon, dessa maneira, marca uma linha divisória entre o imperador transcendente, de um lado, e os políticos, do outro. Daí porque afirma, em uma conclusão evidente de sua argumentação anterior, que o mesmo arbítrio que empregava na vistoria da educação e dos concursos,

punha na nomeação dos senadores, indicados na lista tríplice das províncias, na oportunidade da despedida do gabinete, na escolha do presidente de conselho em substituição dele, na seleção das figuras recomendadas, pelo partido dominante, para os cargos de confiança.

E é exatamente esse conjunto superior de faculdades que os descontentes e prejudicados chamavam, "indignadamente”, “o 'poder pessoal', a 'coroa absorvente', 'caprichos do Olimpo', o 'despotismo do trono"'. Calmon não se preocupa em negar esse suposto "poder pessoal"; diz, pelo contrário, que d. Pedro "exerceu-o sem dúvida, com uma centralização crescente e macia, a cujo sistema se acomodaram os políticos mais intratáveis e autoritários". Interessante notar, então, que d. Pedro, à frente de um Estado tão complexo quanto o Brasil, "misturava velhos e modernos processos de reinar”, aliava inteligência e poder de forma peculiar; quem fosse a São Cristóvão, lá depararia um tipo distinto de governante, era "como um presidente dos Estados Unidos, na Casa Branca, como um czar patriarcal, no imenso império". ${ }^{186}$ Um republicano que não deixava de assumir seu poder monárquico e superior; de uma só vez, era presidente e czar, fusão de diferenças, velhos e modernos processos de reinar.

Tratando, ainda, desse modo peculiar de fazer política, Pedro Calmon comenta um aspecto contraditório - o risco da política apolítica - de d. Pedro II: seu "hábito da minúcia", "que a idade agravou" e acabou por tornar-se, afinal, "um embaraço para ver largamente as questões públicas". O imperador, "munido de lentes grossas, espiava os escaninhos da administração e perdia os aspectos globais e amplos da política". Rigoroso inspetor da moralidade, tornava o regime pouco funcional; era "absorvente, meticuloso, prudente, como se na dobra de cada papel houvesse um alçapão, por onde

\footnotetext{
${ }^{186}$ Pedro Calmon. O rei filósofo: a vida de D. Pedro II. Op. cit., pp. 124-125.
} 
se afundasse o Império... Um terrível funcionário inexorável, vigilante, incansável". ${ }^{187}$ Um problema, talvez, é que essa fiscalização de d. Pedro II se fazia sem as necessárias manhas de um homem político; por isso, ao ver em tudo uma ameaça, um defeito que podia comprometer o todo, não se deu conta de onde estavam, efetivamente, os reais problemas e perigos. É curiosa, nesse ponto, a opinião do historiador, pois, se ele aponta, por um lado, como o imperador soube lidar com temas espinhosos, mesmo aqueles que podiam ir contra sua índole mais aburguesada, tais como os conflitos do Prata, o fim da escravidão e as relações com a Inglaterra, indica, por outro, que o monarca não soube tratar tão bem de assuntos internos, foi incapaz de controlar plenamente, apesar de ter as rédeas em mãos, a politicagem que medrava entre liberais e conservadores, ministros e gabinetes.

Apesar dessa breve crítica, sobressai, ao longo de todo o texto, sempre o d. Pedro estrategista, nem que seja o estrategista do detalhe. Um caso de atuação consistente do monarca, no campo da política interna, foi a criação, tratada como obra espontânea sua, do ministério de Olinda, em 1848. Com este novo gabinete, Pedro II teria controlado parte do jogo político e encaminhado, a bom termo, a questão do tráfico negreiro. Mais do que isso; a crer em Calmon, teria dado um passo decisivo, após ter tirado tudo o que podia dos saquaremas, no sentido da conciliação, o seu grande projeto de governo. No que diz respeito ao controverso tema da conciliação, Calmon lança luz, a todo o momento, sobre a figura do imperador; assim, o acordo político entre os partidos teria funcionado enquanto se ouviu a advertência do monarca, a de que era preciso haver harmonia entre os agrupamentos políticos. ${ }^{188} \mathrm{Ou}$ seja, aquele que está acima dos demais é capaz de fazer o chamado à concórdia, o apelo à prudência; tudo isso, contudo, aparece sem conexão com interesses mundanos, é como se o monarca, garantido por sua transcendência de filósofo, pudesse negociar e não ser influenciado pelo processo de negociação. Nesse período de concordância, era nítido que "o pesadelo da Regência pertencia à História", que a geração dos que viveram os anos atribulados da deposição de d. Pedro I estava superada. Os novos brasileiros, "educados no clima pacífico da Maioridade, não se dignariam examinar as teses do passado: separação das províncias, república, xenofobia". Os tempos eram outros; o que acontecia ao redor do mundo, na segunda metade do século XIX, dava razão ao que dizia e fazia d. Pedro II,

\footnotetext{
${ }^{187}$ Pedro Calmon. O rei filósofo: a vida de D. Pedro II. Op. cit., pp. 126-127.

${ }^{188}$ Pedro Calmon. O rei filósofo: a vida de D. Pedro II. Op. cit., pp. 159-164.
} 
não havia maneira de negá-lo: "Luís Napoleão apossara-se da democracia francesa, a Rainha Vitória restaurara, em Londres, o prestígio da coroa, a Prússia era uma escola militar, os carbonários italianos preferiram um rei, o de Piemonte...". Era a própria história mundial, portanto, quem dava crédito à monarquia brasileira, quem legitimava nosso peculiar imperador. Daí, talvez, o porquê de Pedro Calmon sentir-se tão à vontade para comentar o excesso de minúcia e o apego ao detalhe de sua majestade; eram pequenos defeitos que podiam, e deviam, ser descontados. O Brasil girava junto com a roda do mundo; se, na Europa, estava em voga o ímpeto monarquista, não havia porque rejeitá-lo. $^{189}$

Um momento fundamental no qual se afirmaram as convicções de d. Pedro II foi a Guerra do Paraguai; em um contexto de crise, a coerência e a madura reflexão do imperador se sobressaíram, ficou nítido que, "uma vez adotado um sistema ou aceito um plano", o imperador não mudava facilmente de opinião - uma inflexibilidade, como se pode perceber, que não é entendida como negativa, posto que é legitimada pela excepcionalidade do monarca. Essa foi "a alma da Guerra do Paraguai"; tudo titubeou no decorrer do conflito, ministérios, generais, a política dos países aliados; permaneceu o imperador, "seguro dos seus objetivos, sem esmorecer nem precipitar, árbitro das soluções, fiel ao programa. Se a política exterior do Brasil teve então uma lógica inflexível, foi porque a fez o imperador. Fez pessoalmente". ${ }^{190}$ A guerra, contudo, apesar de afirmar definitivamente seu poder, custou caro ao monarca; findo o conflito, era visível o envelhecimento precoce. Tratava-se de um novo sacrifício: por ser o único capaz de assumir as responsabilidades que assumiu, sofreu as consequências disso em seu próprio físico. A intensidade que empregou nos "tempos aflitos da luta externa", consumiu as "energias de corpo e inteligência", acabou com sua mocidade; tornara-se, imagem que ficara gravada nas memórias, o "velho". Como aponta Calmon, a mudança era notória: “em 1840 fora o 'menino'; o ai Jesus do Brasil. Em 1845 'o homem': a mão forte. Em 1870 o 'velho': tão cedo principiara, como ia acabando...". ${ }^{191}$ No entanto, mesmo gastando a mocidade do monarca, a guerra dilatou-lhe a autoridade, tornou possível iniciar uma verdadeira mudança nacional. Segundo nosso autor, "o Imperador cansara-se de governar um país de rotina" e "promovia ele próprio a revolução social"; "agora, poderoso, inabalável, exigia que o ouvissem"; era o momento de não recuar

\footnotetext{
${ }^{189}$ Pedro Calmon. O rei filósofo: a vida de D. Pedro II. Op. cit., pp. 165-166.

${ }^{190}$ Pedro Calmon. O rei filósofo: a vida de D. Pedro II. Op. cit., p. 223.

${ }^{191}$ Pedro Calmon. O rei filósofo: a vida de D. Pedro II. Op. cit., p. 270.
} 
mais em uma questão que julgava absolutamente necessária: o fim da escravidão. Reuniam-se as condições, "soara a hora da liberdade". Além disso, desgastado, física e mentalmente, desejava, depois de muito esperar, viajar pelo mundo; de acordo com Calmon, surgia um dilema, no qual se imbricavam o nacional e o pessoal: "como se apresentaria na Europa, com o rótulo de Imperador dum tropical país negreiro, espécie de bárbaro fazendeiro cujas passagens, nos barcos de luxo, eram pagas pelo suor dos cativos?",192

Sobre a abolição do trabalho escravo - tema que nosso autor chama, tão sugestivamente, o "rochedo de Sísifo" -, merece destaque a conduta de d. Pedro II, que, mesmo sendo partidário da redenção, soubera evitar, com medidas prudentes, qualquer possível catástrofe. Se dependesse somente do imperador a solução do assunto, não haveria mais demora, ele "cortaria o nó górdio, de uma vez". O problema é que havia interesses em disputa, e é justamente nesse ponto que Pedro Calmon ressalta a sabedoria do monarca. De acordo com o autor, "os homens eram fracos diante das circunstâncias: o eleitorado, a lavoura, a riqueza, apoiavam-se no eito da fazenda onde a raça cativa mourejava de sol a sol". ${ }^{193}$ Coube ao imperador, portanto, colocar-se acima de interesses econômicos e políticos, garantir a manutenção da ordem e saber conter tanto os ímpetos abolicionistas quanto os reclamos dos grandes proprietários; esse foi o seu papel: “moderador, algodão entre cristais, magistrado. Realmente, tudo, à volta dele, era diferente e novo. Continuava igual a si mesmo. Os outros - afirmava - teriam juízo; eram brios de classe, nuvens que passavam". ${ }^{194}$ Perceba-se como Calmon realiza um interessante jogo em sua narrativa: aquilo que é positivo, tal como a vitória na Guerra do Paraguai, resulta da ação pessoal do imperador; aquilo que pode ser questionado, como é o caso da demora na abolição, apesar da sábia mediação do monarca, depende de fatores que escapam ao pessoal. Aquilo que ele pode garantir é o bom encaminhamento da questão, mesmo que a solução não seja imediata.

Neste ponto fundamental, o texto ganha em drama. Justamente no mais aceso da questão escravocrata, o imperador adoeceu; o organismo não aguentou, o físico traiu, fraquejou a superior inteligência do homem. Convalescente, seguiu para a Europa a fim de tratar-se; ia sem saber se voltava. Ao abordar esse contexto de dificuldades, a biografia de Calmon vai se tornando, no que diz respeito ao imperador, volúvel: em

\footnotetext{
${ }^{192}$ Pedro Calmon. O rei filósofo: a vida de D. Pedro II. Op. cit., p. 279.

${ }^{193}$ Pedro Calmon. O rei filósofo: a vida de D. Pedro II. Op. cit., pp. 354-355.

${ }^{194}$ Pedro Calmon. O rei filósofo: a vida de D. Pedro II. Op. cit., p. 369.
} 
alguns momentos ele aparece nostálgico, abatido pela doença e pela crise; em outros, surge disposto, passeando atarefado pela Europa, ávido por "livros, interlocutores, movimento". Depois da abolição, quando retorna ao Brasil, é recebido calorosamente pelo povo carioca. Essa sinuosidade é, talvez, decorrência do fato de que, neste livro, o foco está sempre sobre d. Pedro; assim, esses detalhes dão ritmo novelesco à obra e constroem uma história nacional que segue sempre colada à história pessoal.

Falando sobre os momentos posteriores à abolição da escravatura, breves tempos de júbilo para o imperador, Calmon se permite uma cena de metalinguagem, pois comenta que, "no Instituto Histórico, lembraram que era urgente nomear-se a comissão que coligisse os dados, para a grande biografia do Imperador. Vinha aí o jubileu...". O marco do Segundo Reinado, os cinquenta anos de d. Pedro II no poder, merecia uma comemoração, um livro a celebrar-lhe as glórias; logo, que se escrevesse uma obra. Interessante é ler qual teria sido, diante do aventado projeto, a resposta do monarca:

- Biografia? - surpreendeu-se; e com benevolência: Não pensem nisso. Aliás, é simplíssima. No alto de uma folha de papel escrevam a data de meu nascimento e do dia em que subi ao trono; no fim, quando faleci. Deixem todo o intervalo em branco para o que ditar o futuro; ele que conte o que fiz, as intenções que sempre me dominaram e as cruéis injustiças que tive de suportar em silêncio, sem poder jamais defender-me. ${ }^{195}$

Em passagens como esta, interessantíssimos diálogos que se fazem como em uma obra literária, sem referência a nenhum documento que certifique as palavras do autor, como diferenciar este livro de um romance? A diferença, evidentemente, está na intenção, no sentido da obra, na abordagem do tema. No entanto, no que diz respeito à forma, são marcantes as semelhanças; o texto de Calmon, em alguns instantes, e quase que deliberadamente, ganha claros contornos ficcionais, tal como nesta passagem, em que se quer exaltar a modéstia do imperador e salientar a importância de uma biografia a seu respeito. Nesse sentido, o trecho que trata do embarque na lancha que levaria a família imperial, no meio da noite, para o exílio, é emblemático. Pedro Calmon cria uma cena de rara tensão, na qual o movimento das ondas, o balançar da embarcação, o risco do imperador cair na água - "no abismo"- e afogar-se na escuridão, é metáfora da situação vivida com a proclamação da República, das dúvidas e dilemas, dos remorsos já perceptíveis nos militares e partidários do novo regime. É uma passagem notável, que expressa bem o sentido de todo o livro; após toda a tensão, o monarca, ao amanhecer,

\footnotetext{
${ }^{195}$ Pedro Calmon. O rei filósofo: a vida de D. Pedro II. Op. cit., pp. 393.
} 
olha para a baía de Guanabara, para a bela paisagem e, a crer em Calmon, sente a tristeza de ter de deixar a terra natal:

O imperador imobilizara-se num banco, fitando a costa, as penedias coroadas de arvoredo, o recorte da terra brasileira marginada de praias brancas. Uma suave insensibilidade chumbava-o àquela contemplação, em que se misturavam reminiscências, melodia, saudade, indulgência. Governara esse grande Império tanto tempo que nem se lembrava de quando - apenas príncipe - lhe chamavam Alteza. Vira-o crescer. Cresceram juntos. Envelhecera ele; podia morrer. Mas o país era cada vez mais jovem, mais trepidante, mais imprevisto. E que linda paisagem! Concordavam a Imperatriz, D. Isabel, o Conde d'Eu: mais lhe amargava o abandono da terra querida. ${ }^{196}$

A família imperial, deposta e expulsa do Brasil, é descrita como um conjunto de vítimas. Depois do Quinze de novembro, o texto assume ares sentimentais e consternados, revela grande preocupação com o destino dos exilados; a linguagem se torna carregada e centrada em descrições, nos detalhes físicos e psicológicos dos personagens. A primeira baixa entre as vítimas foi o jovem Pedro Augusto, cuja frágil compleição psíquica não suportou os eventos de novembro de 1889; já no trajeto do exílio tivera sérias crises nervosas, que culminariam em sua internação na Suíça. A segunda, uma perda das mais dolorosas, era a imperatriz Teresa Cristina, cuja morte, ocorrida em Portugal, a 28 de dezembro de 1889, fez d. Pedro chorar, ficar incapaz de concentrar-se nos livros, "sentir Vontade de tombar de joelhos". 197

O tema do exílio abre perspectivas para uma nova discussão, que revela a permanência de d. Pedro II na memória nacional. Nos anos finais de sua vida, Calmon fez parte do Conselho Editorial da Biblioteca do Exército; e foi pela editora dessa instituição que, em 1975, no contexto do sesquicentenário do imperador, publicou nova edição, revista e com algumas alterações, de seu livro. Além do título, que foi invertido - A vida de D. Pedro II, o rei filósofo - as modificações limitam-se, em sua maior parte, a questões de linguagem, tais como a exclusão de algumas palavras carregadas de sentidos e subentendidos: "selvagem", "radical”, "autoritarismo", dentre outras; é como se se quisesse purgar o texto de maiores comprometimentos ideológicos e torná-lo mais politicamente correto. Mudanças realmente significativas, contudo, aparecem nos dois últimos capítulos, justamente os que tratam do exílio e morte do imperador. O capítulo "Sol posto", o penúltimo, na edição de 1938 apresenta uma narrativa detalhada e consternada dos sofrimentos de d. Pedro II em seus últimos momentos de vida. O

\footnotetext{
${ }^{196}$ Pedro Calmon. O rei filósofo: a vida de D. Pedro II. Op. cit., p. 423.

${ }^{197}$ Pedro Calmon. O rei filósofo: a vida de D. Pedro II. Op. cit., p. 456.
} 
monarca está doente, com uma gangrena no pé e abandonado pelo seu país, sem notícias de sua terra natal; foi esquecido mais rápido do que poderia ter imaginado, vive o silencioso martírio do exílio. Apesar de tudo, segue obstinado na sua busca por conhecimento, frequenta o Instituto e a Academia Francesa. Essa é a tônica: o imperador, completamente abandonado, luta, da forma como melhor consegue, por sua sobrevivência.

Na edição de 1975, um pouco melhor documentada, a narrativa é mais leve; nela não surge um d. Pedro II tão vitimado - o espírito é o mesmo do que aparece, por exemplo, na epígrafe dessa seção. É um texto não de todo seco, mas menos propenso a sentimentalismos e impressionismos. Diferença mais evidente, entretanto, se percebe no que diz respeito ao derradeiro capítulo, intitulado, na primeira edição, "Um pouco de terra..."; na de 1975, “O fim”. O título original foca no detalhe, naquilo que, a partir de sua pequenez, consegue expandir-se e consagrar o mito, tornando-lhe quase infindo, tal como dão a entender as reticências. A segunda versão é objetiva, sua função está clara na definição, não deixa rebarbas, nem subentendidos; é o fim, ponto final, sem reticências. Direto e utilitário. Já que o foco é no detalhe, perceba-se um fato curioso: o pouco de terra citado no título original é o que estava dentro da almofada que ficou junto ao corpo do monarca no momento de seu velório. Na publicação de 1975, a tal almofada, no decorrer da narrativa, não fica sob a cabeça do falecido, mas serve de apoio aos pés. É uma diferença mínima, mas insinuante; inversão curiosa e pontual, que indica - da mesma forma que a inversão no título do livro - uma intenção de reconhecer o mito e, ao mesmo tempo, contê-lo, encerrá-lo dentro de um limite aceitável e com o qual se possa trabalhar sem ser por ele englobado. Muito intrigante perceber que as maiores diferenças entre as duas edições aparecem exatamente no momento em que d. Pedro II vai deixando de ser um personagem histórico para se tornar um elemento de memória; no momento em que o foco sai do Império para recair na República. Nesse movimento de transição, surgem os maiores dilemas. A passagem citada a seguir, retirada da edição de 1938, carrega nas tintas do drama; comentários como esse, que podiam ter muito significado nos anos finais da década de 1930, no contexto de crise vivido à época, certamente gerariam incomodo na edição de 1975:

A revolução fora mais profunda do que imaginava [d. Pedro II]. Antes de ser das armas - em choque - era dos espíritos - perplexos... No princípio, todos tinham pensado como Saraiva, que justificava a adesão ao novo regime dizendo, paternalmente: é preciso guiar os meninos... Não tinham experiência! Mas, de fato, não caíra somente o trono, desabara uma 
época. Havia pressa em sepultar-se um século. O positivismo pretendia varrer a Igreja; a República, como ordem mental, como outra "forma" de organização social, substituía o Império; desapareceram "vossas excelências", e todos se tratavam por "vós"; apenas alguns caturras insistiam em assinarem-se barões ou viscondes; o "encilhamento" desequilibrara o consenso público, a latente agitação do país fizera o resto... Governo forte, repressão da imprensa de oposição, jacobinismo enfurecido (devia-se pôr abaixo a estátua de D. Pedro I, raspara-se das fachadas dos prédios o escudo imperial, andara-se a demolir quanto símbolo falasse da monarquia defunta, entre ruidosas cóleras populares), intolerância, frenesi de Bolsa, acomodação tímida, produziam um ambiente nervoso e indefinível. [...] $\mathrm{O}$ carro do Estado leigo triturava, numa áspera escalada, um chão de relíquias. Seria lógico que a um repelão mais insólito se desbancasse Deodoro de sua boleia. Foi o que aconteceu. ${ }^{198}$

Essa passagem, sintomaticamente, não aparece na reedição publicada pela editora do exército. As referências a uma época de agitação, questionamentos ao poder, repressão, jacobinismo e mudança de ordem política, não tinham como agradar aos patrocinadores da nova edição. Há, portanto, uma espécie de autocensura por parte do autor, que descarta um trecho de seu texto original, talvez por achá-lo, agora, um tanto exagerado. Assim, a memória, através da narrativa histórica, vai sendo purgada de seus aspectos conflituosos; surge uma história de mudanças, mas desde que feitas sem lutas e debates. Levando além essas colocações, será permitido, aqui, fazer algumas especulações? O que significava, em 1975, o exército patrocinar a publicação de uma biografia de d. Pedro II? Lembre-se que, três anos antes, os militares haviam restaurado na memória nacional a figura de d. Pedro I, trazendo, inclusive, os seus restos mortais para o Brasil. As relações entre o exército e o segundo imperador, contudo, sempre foram complicadas e ambíguas, marcadas por aproximações e afastamentos; além disso, foram os militares que, não havia como negar, o derrubaram, através de um golpe. No contexto do regime militar, notadamente do governo Ernesto Geisel (1907-1996), publicar uma obra como a de Pedro Calmon não seria um sinal, por mínimo que seja, de que os militares queriam ser menos d. Pedro I e mais d. Pedro II? Desejavam, como já fizera Getúlio Vargas algumas décadas antes, cultuar a memória de um governante moderado, conciliador, metido a sábio e ligado ao progresso e a moral, de um verdadeiro rei filósofo? Na apresentação à edição de 1975, o tom voluntarista, laudatório e conciliador fica evidente:

Ao associar-se às homenagens que vêm sendo prestadas a D. Pedro II em razão de seu Sesquicentenário de Nascimento, a Biblioteca do Exército - Editora inclui a presente obra em sua programação, livro cuidadoso e

\footnotetext{
${ }^{198}$ Pedro Calmon. O rei filósofo: a vida de D. Pedro II. Op. cit., p. 454.
} 
especialmente preparado para os assinantes da coleção General Benício por Pedro Calmon, historiador acima dos qualificados. / A Biblioteca do Exército, que tem sua criação diretamente vinculada a D. Pedro II, uma vez que foi esse Monarca quem assinou o Decreto de sua instituição, nos idos de 17 de dezembro de 1881, não poderia deixar de estar presente com sua contribuição, justamente agora que se comemora, em todo o País, os cento e cinquenta anos de nascimento de tão ilustre varão. ${ }^{199}$

Nessa mesma introdução, Pedro Calmon ressalta que o objetivo é oferecer ao público, "que aprecia os sinceros e velhos, os grandes e famosos modelos humanos, preferindo a verdade - na memória - à ficção - na fábula", nada menos do que "a longa verdade sobre esse indivíduo raro, aos seis anos de idade imperador, aos 14, soberano, durante perto de cinquenta anos encarnação da autoridade - e árbitro do poder”. O autor estabelece uma oposição entre verdade-memória e ficção-fábula; o que dá a entender que, em sua perspectiva, sempre houvera obras negativas acerca do monarca, mas que somente mereciam ser entendidas como fábulas, textos de ficção, pouco reputáveis de respeito. A verdade, portanto, estaria na escrita da história, na celebração da memória, no resgate dos grandes modelos humanos e nacionais. O interessante é que, como já comentado, em muitos momentos o próprio texto de Calmon, mesmo não o sendo, se aproxima bastante de uma obra de ficção, posto que cria diálogos, investe na linguagem floreada e na criação de impressões fortes.

Ainda nessa introdução de 1975, Calmon continua rasgando elogios ao biografado, ressaltando seu preparo e seu poder sem excessos - "o chefe de Estado que mais se demorou no governo, o único educado exatamente para isso, nesta América em que se enquadrou a sua existência sem cobiça e o seu império sem imperialismo" -, mas também é rápido em, de maneira sutil, realçar qualidades de seu próprio trabalho. Logo, diz assim:

longe de ser uma apologia, é um estudo da personalidade tranquila, da mania de erudição, da tolerância instituída, do proveitoso bom-senso, do nacionalismo crédulo, da administração diuturna, da política hábil, dos acertos e dos erros do estadista, cuja vida Joaquim Nabuco sonhou escrever". ${ }^{200}$

É curioso perceber que, ao elogiar o biografado, ao comentar acerca das características e intenções de seu trabalho, Pedro Calmon refere-se ao intento frustrado de Joaquim Nabuco; dessa forma, acaba por situar a si próprio na historiografia: afinal,

\footnotetext{
199 Pedro Calmon. A vida de D. Pedro II, o rei filósofo. Edição especial comemorativa do sesquicentenário de seu nascimento. Rio de Janeiro: Biblioteca do Exército, 1975, p. V.

${ }^{200}$ Pedro Calmon. A vida de D. Pedro II, o rei filósofo. Op. cit., p. VIII.
} 
fez, em duas ocasiões distintas, aquilo que Nabuco, o grande Nabuco, não fizera. Portanto, o narrador da vida do rei filósofo, era, ele também, uma notável inteligência a ser louvada. Além do mais, lembre-se que nesse mesmo ano de 1975, vinha a público, através da pena de Calmon, a obra definitiva sobre o monarca: uma imensa História de D. Pedro II, composta de cinco volumes ilustrados. Outra obra, outro monumento de palavras dedicado à memória do imperador. Assim, permeado pelo contexto vivido, estruturado pela escrita e legitimado pela instituição de onde fala, fecha-se sempre um ciclo de legitimidade entre biografado, obra e autor. Cada um dos fatores situando e dando sentido aos outros.

\section{1 .3. Max Fleiuss: um rei prometido, para uma terra prometida}

"O processo industrial, comercial, econômico e financeiro do Brasil, como a sua cultura científica, artística e literária tudo deveram a d. Pedro II".

Max Fleiuss, em Dom Pedro Segundo.

No ano de 1940, por ocasião do centenário da proclamação da maioridade de d. Pedro II, o historiador Max Fleiuss - que, conforme já comentado, foi, entre outras coisas, responsável pela alocução proferida no dia da inauguração do mausoléu de Petrópolis, em 5 de dezembro de 1939 -, publicou, sob os auspícios do Instituto Histórico e Geográfico Brasileiro, o livro Dom Pedro Segundo. O teor laudatório de tal obra fica evidente a todo o momento; por exemplo, o comentário inicial do autor, feito à guisa de introdução, vem datado de 23 de julho de 1940; ou seja, exatos cem anos da maioridade. A intenção de criar uma relação com o passado é nítida; aproveita-se o estabelecimento de um novo marco cronológico para se cultuar os tempos idos.

Max Fleiuss era figura de grande destaque nas fileiras do IHGB, sendo seu secretário desde 1905; de acordo com Lilia M. Schwarcz - que o caracteriza como "um profissional de institutos", já que, entusiasta desse modelo de instituição, era membro de diversas academias, sociedades e organizações afins, tanto nacionais quanto internacionais -, no Instituto, ele "cumpriu no primeiro período republicano o mesmo papel que seus colegas haviam desempenhado durante o regime anterior". Tal 
informação é, como se verá, de grande importância, porque o autor, ao menos no que diz respeito a d. Pedro II, efetivamente realizou, em nome do ideal nacional, uma comunhão entre temporalidades e regimes políticos. Schwarcz chama atenção, ainda, para o interessante fato de que, a partir de sua nomeação como secretário, Fleiuss alterou "a data das sessões magnas - realizadas até então no dia da primeira participação do imperador no IHGB - para 15 de novembro, como homenagem ao novo regime". Dessa forma, "sem esquecer a monarquia, e em especial d. Pedro II, considerado 'protetor perpétuo' do estabelecimento, Fleiuss garantia uma nova aliança com os representantes da República, que a partir de então ganhavam um acesso mais formalizado aos recintos do instituto". ${ }^{201}$ Vislumbra-se, então, a partir desses comentários, uma ideia central a nortear a obra em questão, uma chave de leitura e interpretação; qual seja, a de que a República não era, necessariamente, uma ruptura na história do Brasil, mas sim uma efetiva continuação do processo de construção nacional - processo que, é possível assim imaginar, atingira o ápice com o Estado Novo. Dessa maneira, somente pela concórdia entre passado e presente é possível vislumbrar uma possibilidade harmônica de futuro; d. Pedro II serve como o elemento fundamental para reatar o fio da história nacional e para, além do mais, legitimar o lugar do IHGB na historiografia brasileira.

Tal postura fica evidente antes mesmo do início do texto propriamente dito. $\mathrm{O}$ livro se abre com quatro citações, das quais as duas primeiras merecem destaque. A epígrafe inicial é de ninguém menos que Getúlio Vargas; o que vem citado é o seguinte: "Vencido pela revolução política, destronado, exilado, d. Pedro conduziu-se, por sua vez, com admirável dignidade, acatando silenciosa e resignadamente a decisão do seu povo e desaconselhando as maquinações reacionárias contra o novo regime". ${ }^{202}$ Fica notória a ideia de que o próprio presidente em exercício, à época da publicação do livro, era o primeiro a reconhecer que o monarca se sacrificara por seu país; mais do que isso, verdadeiro exemplo de dignidade e respeito para com o povo, ele não aceitara nenhum tipo de revanchismo ou de maquinação contra o regime republicano. D. Pedro II, pelas palavras de Vargas, é um exemplar homem público, que entende os limites e necessidades de seu cargo, que atende aos interesses nacionais, mesmo que sejam contrários aos seus próprios.

\footnotetext{
${ }^{201}$ Lilia M. Schwarcz. O espetáculo das raças. Op. cit., p. 107.

${ }^{202}$ Max Fleiuss. Dom Pedro Segundo. Op. cit., p. 3.
} 
A epígrafe seguinte é de Epitácio Pessoa (1865-1942), presidente em exercício quando do retorno dos restos mortais do casal imperial ao Brasil. $\mathrm{Na}$ frase atribuída a Pessoa, além de estarem destacados os fatos de que d. Pedro II era o único representante "verdadeiramente nacional da dinastia a cuja sombra nascera a nossa pátria e se consolidara a nossa independência", e de que fora um chefe que nos dera "meio século de moralidade, de justiça e de progresso", um efetivo "coração magnânimo", retoma-se a ideia fundamental de que ele "nunca deixara escapar uma queixa contra aqueles que de tudo o haviam despojado; patriota que até o último sopro de vida não tivera outro pensamento que não fosse a felicidade da terra comum". ${ }^{203}$ São, portanto, duas citações que se encontram em um feixe de ideias comuns; além do mais, dois comentários feitos pelos presidentes da República que deliberadamente se ocuparam em resgatar a imagem de d. Pedro II: Pessoa com o retorno, Vargas com a construção do mausoléu. Dois políticos, em outras palavras, que cultuaram o passado a partir de necessidades e interesses presentes. A partir dessas citações, cabe a seguinte pergunta: se d. Pedro II não nutrira um espírito revanchista, por que caberia aos contemporâneos, republicanos bem esclarecidos, ter sentimentos afins para com ele? Mais do que isso, o imperador fora um destacado agente histórico e, de certa forma, símbolo nacional; sua memória era de grande importância para o Brasil, pois era, acima de tudo, a memória de um patriota; através do arranjo de duplos sobre o qual se estabelecera, sua imagem não estava ligada a nenhuma corrente específica, a nenhum projeto político partidário. Era, assim, um vulto envolvido por aparente neutralidade, um ídolo a ser lembrado por todos; não sem motivo que, mais para o fim do livro, o autor afirmará, de forma categórica:

A figura de d. Pedro II não mais exprime um credo político; não é a bandeira de um partido; não é um programa de oposição. Ninguém hoje deixa de reconhecer que o imperador foi o Brasil de 1840 a 1889 . O grande parêntesis revolucionário em que viveu, reinou e caiu foi indiscutivelmente um dos trechos mais brilhantes de nossa história, a qualquer aspecto que o encaremos. ${ }^{204}$

Nessa linha de pensamento, é preciso resgatar essa figura que foi, durante quase cinquenta anos, o próprio Brasil; conhecer os detalhes de sua biografia e cultuá-la naquilo que possa legar ao presente enquanto modelo de conduta. Necessário, portanto, partir para o estudo da vida do grande líder. Em um primeiro momento, Fleiuss vai abordar, como não poderia deixar de ser, a infância do monarca. No que diz respeito à

\footnotetext{
${ }^{203}$ Max Fleiuss. Dom Pedro Segundo. Op. cit., p. 5.

${ }^{204}$ Max Fleiuss. Dom Pedro Segundo. Op. cit., p. 92.
} 
linguagem, notam-se lances poéticos: "na meninice do imperador, brincam raios de ouro da aurora através de densos véus de crepe mortuário". ${ }^{205}$ Se o destino, por conta dos raios de ouro, se mostrava alvissareiro e luminoso, as notas de tragédia, tal como a morte precoce de sua mãe, D. Leopoldina (1797-1826), e a partida do pai e madrasta para Portugal, já estavam nuançadas nos densos véus de crepe mortuário. Está traçada, desde cedo, uma vida de glórias, na mesma proporção que de sacrifícios e sofrimentos; trata-se, com provações e superações, de um efetivo arquétipo de herói nacional.

A infância de d. Pedro II, assim como, segundo sugere Fleiuss, soe ocorrer a todos os reis e "homens célebres", foi uma fase encantadora de sua biografia. De acordo com o autor, a do imperador guarda grande semelhança com a do "legislador hebreu, que conduziu o povo de Israel pelo deserto em demanda da terra de promissão". Aparece, aqui, de maneira um tanto estonteante, uma das características mais marcantes do texto de Fleiuss: as constantes referências bíblicas, que lhe servem de inspiração para tratar da vida do imperador. Se Moisés tivera seu rústico cesto de vime emaranhado lançado ao Nilo, sujeito às violentas intempéries e cheias do rio, d. Pedro II também se vira à mercê de grandes perigos: seu berço fora "abandonado pelo destino entre os sargaços das revoluções liberais" e esteve à mercê de turbulências, "prestes também a ser absorvida pela maré montante da guerra civil que convulsionava o país; um movimento sísmico que ameaçava o país de esfacelamento". Dois caminhos trágicos, que não inspiram grandes perspectivas e esperanças. No entanto, apesar de tudo, e assim como acontecera ao povo de Deus, "ao da Terra de Santa Cruz valeu sempre a providência divina". ${ }^{206}$ A imagem mítica elaborada pelo historiador impressiona. Trata-se, então, nada menos do que de um rei prometido para uma terra prometida; logo, desde o começo da colonização, quando a América portuguesa era ainda chamada Terra de Santa Cruz, havia uma obra divina em marcha, um destino grandioso estava sendo traçado. Perceba-se um pequeno, porém importante, detalhe: a publicação, segundo consta na dedicatória do volume, foi feita em "homenagem a Portugal", o que, em parte, torna possível compreender a referência feita à "Terra de Santa Cruz”. Está-se falando, assim, de uma história única e que avança a passos decididos; desde o momento da chegada dos primeiros colonizadores lusitanos, até o contexto presente, há uma unidade de sentido e uma comunhão de interesses, uma

\footnotetext{
${ }^{205}$ Max Fleiuss. Dom Pedro Segundo. Op. cit., p. 51 e p. 53.

${ }^{206}$ Max Fleiuss. Dom Pedro Segundo. Op. cit., p. 9.
} 
epopeia nacional que se conduz a partir da ação dos homens e de Deus. A história do Brasil é tratada de forma contínua, sem rupturas ou divisões; mesmo que tenha chamado o Segundo Reinado de "parêntesis revolucionário", o sentido que Fleiuss dá ao termo é de aceleração e modernização, "um dos trechos mais brilhante de nossa história"; não se trata, portanto, de uma mudança traumática, e sim de uma transformação conduzida, de forma ordeira e progressiva, pelo rei prometido, o Moisés da pátria. Dessa maneira, da colonização ao Estado Novo, emerge uma história teleológica; vem à tona uma grande nação que já se podia vislumbrar desde o século XVI. O período fundamental para que isso tivesse ocorrido, a grande guinada, o dínamo acelerador: os cinquenta anos nos quais d. Pedro II governou.

Max Fleiuss, algo recorrente nos textos favoráveis ao monarca, na parte inicial da obra, dá bastante destaque à figura de D. Mariana Carlota Verna de Magalhães Coutinho, depois titulada Condessa de Belmonte, camareira-mor do Paço. Essa distinta senhora cumprira função fundamental, fora uma espécie de segunda mãe para o jovem órfão da pátria; teria sido uma das pessoas que, desde cedo, incutiu fortes lições de moralidade ao futuro imperador. De acordo com o autor, ela "ensinou-lhe a ser o que foi"; o que significa dizer, numa apreciação que quase não deixa margens a críticas, "um dos maiores chefes de Estado em todas e quaisquer formas de governo que o mundo conhece". Para Fleiuss, então, d. Pedro II foi um rei excepcional, acima de sistemas políticos e disputas de poder; foi, como diz um pouco mais adiante, "o grande vulto de um rei bíblico, patriarcal como Davi, e simultaneamente herói criador, como Washington, e chefe de uma das maiores democracias coroadas, como disse Mitre". ${ }^{207}$ Salta aos olhos o cabedal de referências que o autor aborda para construir o retrato deste monarca: no seu repertório contam elementos bíblicos e referências a grandes líderes, mesmo que fossem, como é o caso de George Washington (1732-1799), um dos fundadores de uma República. Logo, e trata-se de um fato de grande relevância, o d. Pedro II abordado no texto é alguém que escapa aos limites da política e está além de imposições cronológicas. É uma figura memorável e insuperável, pairando pelo tempo e beirando o mítico. Daí porque, como fica claro desde as epígrafes, este livro é uma interpretação que visa, acima de tudo, reatar os laços, superar desavenças, vencer conflitos, redimir a República de qualquer injustiça cometida contra o monarca; é uma proposta de aceitação do novo, mas desde que isso não represente a negação de um dos

\footnotetext{
${ }^{207}$ Max Fleiuss. Dom Pedro Segundo. Op. cit., pp. 12-13.
} 
grandes vultos do passado nacional. Afinal, negar d. Pedro II seria rejeitar a própria grandeza da história pátria.

A fim de esquematizar seu estudo, Max Fleiuss estabelece uma divisão do Segundo Reinado em três etapas. A primeira, entre 1840 e 1850, "corresponde ao período de consolidação de paz interna e assinala o sufocamento das rebeliões oriundas, umas da indisciplina militar dos últimos anos do Primeiro Reinado, e outras do interregno regencial, ou surtas depois da Maioridade". A segunda fase, que vai de 1850 a 1870 , se refere ao período em que estão concentrados todos os conflitos na região do Prata; nela, a figura de d. Pedro II "começa a surgir na mais forte expressão política do papel de assegurador da paz entre Brasil e as Repúblicas do Prata, extinguindo as ditaduras de Rosas, Aguirre e López". ${ }^{208}$ Salta aos olhos, a partir da referência a outros governantes latino-americanos, como d. Pedro II - através de sua transcendência garantida pela combinação do sagrado e da ciência -, assegurador da paz e inimigo das arbitrariedades, não podia ter concorrentes, não podia ser superado por nenhum rival. A terceira fase iria de 1870 até a deposição do monarca, e teria sido marcada pelas leis de abolição do trabalho escravo e pelo surgimento do movimento republicano, sendo que, em ambos os fatores, a figura do monarca cumpriu importante papel, posto que jamais reprimiu nenhuma manifestação, nem retirou seu apoio a nenhuma medida antiescravista.

No conjunto, uma característica específica dessa obra - que se propõe, mesmo, mais ligeira e centrada em d. Pedro II - é que os assuntos são tratados de forma um tanto quanto acelerada; não aparecem processos sociais a dar corpo e sentido a disputas e lutas, tudo gira em torno do monarca, que sabe o melhor para o país e toma as medidas adequadas. Por exemplo, uma das grandes conquistas do imperador, feita na segunda fase de seu regime, teria sido a conciliação política, posto que, com a concórdia política estabelecida, foi possível fazer melhorias. Como diz Fleiuss, quando o marquês de Paraná, a 6 de setembro de 1853, foi convocado para organizar o gabinete chamado de "Conciliação", quem mais ganhou com isso foi o próprio Brasil; a partir de então, foram "construídas as suas primeiras vias férreas; estabelecerem-se as primeiras linhas telegráficas; fundaram-se as primeiras linhas de navegação fluvial"; se viu "apurar-se a instrução pública; tratar-se da imigração e da colonização; executar-se, enfim, toda a

\footnotetext{
${ }^{208}$ Max Fleiuss. Dom Pedro Segundo. Op. cit., p. 61 e p. 63.
} 
natureza de reformas úteis". ${ }^{209}$ Dessa maneira, "socialmente, encetava-se a obra colossal do Segundo Reinado que, depois de pacificar o Brasil-político, passou a criar o Brasil administrativo, intelectual, econômico, industrial, científico e artístico". Entende-se, agora, com mais clareza, o que Fleiuss quis dizer com o "parêntesis revolucionário" do Segundo Reinado; o Brasil, nesse período, passava por intensas transformações internas, começava a ter, mais do que nunca, uma administração interna organizada e dinâmica. À cabeça de tudo estava o imperador, que recebera o país com quase nada, nenhuma infraestrutura, "sem um quilômetro de estrada de ferro" ou "uma locomotiva em tráfego, sem um barco a vapor a navegar em nossos rios e nossa costa, sem um fio telegráfico a eliminar longitudes, a ligar a vastidão sem fim de nosso território; sem um combustor público do primeiro gás a iluminar a capital do Império”. A marca principal de tão distinto governante, contudo, era a dedicação e o sacrifício; afinal, “d. Pedro II nada encontrou e tudo fez pelo Brasil". ${ }^{210}$ Entretanto, mais do que a obra de modernização e a estruturação de um país administrativo, a principal conquista de d. Pedro II, cuja atuação política, mesmo que contida em alguns momentos, era inconteste, foi que ele conseguiu "evitar com a sua investidura, a perturbação da ordem, senão a dissolução do Império", "sendo, nas últimas décadas do regime, quem mais completa noção possuía de todos os negócios públicos, conhecendo também o valor e a aptidão dos grandes servidores da pátria". ${ }^{211}$ Portanto, tudo o que representa algum avanço neste país, seja no campo administrativo, econômico ou cultural; tudo o que emana da ordem política e social; tudo, enfim, que é necessário para a existência e prosperidade de uma nação, devemos a esse grande monarca.

A intenção, então, é fomentar o reencontro do rei destituído com sua terra e sua gente. Nesse esforço, fica evidente a seleção dos fatos perpetrada pelo historiador, tanto que, após o capítulo de abertura, intitulado "Primeiros tempos", emenda logo o seguinte, sugestivamente chamado "Dom Pedro Segundo no Instituto Histórico". Constrói-se a imagem de um d. Pedro II extremamente sábio e honesto, ligado às artes e à cultura; assim, nada melhor do que fazer tudo a partir da perspectiva, órgão tão prezado pelo imperador, do IHGB. Note-se um aspecto fundamental: ao abordar seu tema, o autor acaba legitimando a si próprio e ao lugar de onde fala. Segundo Fleiuss, “d. Pedro II foi, antes de tudo, um desvelado estudioso dos homens e das coisas

\footnotetext{
${ }^{209}$ Max Fleiuss. Dom Pedro Segundo. Op. cit., p. 64.

${ }^{210}$ Max Fleiuss. Dom Pedro Segundo. Op. cit., p. 63.

${ }^{211}$ Max Fleiuss. Dom Pedro Segundo. Op. cit., p. 135.
} 
pátrias". Sua sede de conhecimento era imensa, não havendo assunto pelo qual não demonstrasse interesse. Apesar da multiplicidade de interesses, o monarca era

dotado de prodigiosa memória e vasta cultura no tocante às matérias a que especialmente se dedica o Instituto, difícil era mesmo surpreendê-lo no mais leve engano acerca de um nome, de uma data, ou do mais insignificante traço de um episódio da história universal, de que, desde menino, fez seu estudo predileto. ${ }^{212}$

O texto, dessa maneira, vai se fechando em um ciclo de autolegitimidade. Aborda-se uma figura excepcional, reconhecida, ao redor do mundo inteiro, pelos grandes sábios de seu tempo. Tal figura era grande apoiadora do Instituto; mais que isso, era seu primeiro membro e defensor, um estudioso apaixonado de história e geografia, a quem nada escapava, nenhum mínimo detalhe. Como reconhece o autor, mais de uma vez, o imperador se recusava a ser somente um "protetor coroado de nossas letras, artes e ciências, ou um mecenas, ignorante da arte do belo, que só buscasse o convívio dos nossos vates para com eles improvisar-se artista ou libertar-se às regiões etéreas do Parnaso". Muito além de cumprir o papel de incentivador, o que, por si só, já seria de grande importância para o Brasil, o monarca, e isso the garantia autoridade política, era um "senhor de cultura clássica pouco vulgar"; talvez, "o brasileiro mais culto da sua época e a par de todo o movimento artístico e científico do mundo". ${ }^{213}$ Ao falar de sua vida, então, qual a melhor forma de abordá-la se não fazer, a partir da perspectiva do IHGB, uma historiografia erudita, detalhista, voltada para a minúcia, a descrição, o reconhecimento dos grandes homens? Não seria esse um modelo de história amplamente admirado pelo próprio imperador? Assim, ao mesmo tempo em que se defende o biografado, se legitima a forma de abordá-lo e a instituição a partir da qual se faz isso, cada coisa justificando e constituindo a outra. Tema e forma, assunto e estilo, ideia e método, são todos fatores que não se separam. É um ciclo, portanto, garantido pelo próprio fazer historiográfico. ${ }^{214}$

\footnotetext{
${ }^{212}$ Max Fleiuss. Dom Pedro Segundo. Op. cit., p. 28.

${ }^{213}$ Max Fleiuss. Dom Pedro Segundo. Op. cit., p. 33.

${ }^{214}$ Sobre o esforço de autolegitimação, leia-se, também, a seguinte passagem: "A leitura era o seu prazer favorito. Lia sempre, e a prova disso é que dos 60 mil volumes de sua coleção bibliográfica, existente hoje no Instituto Histórico e Geográfico Brasileiro e na Biblioteca Nacional, composta do mais variado gênero, compreendendo astronomia, história, ciências naturais, literatura, etc. - quase todos encerram sob a forma de anotações, de próprio punho, comentários, reveladores de erudição, sobretudo no tocante à glotologia, filosofia, arqueologia, etnografia, geografia e história, ciências naturais, sociais e políticas". Max Fleiuss. Dom Pedro Segundo. Op. cit., pp. 48-49. É um esforço impressionante, uma tentativa de louvar, de forma exaustiva e repetitiva, os conhecimentos todos do monarca, essa sabedoria que lhe fazia legítimo e necessário ao Brasil. É um acúmulo de interesses que parece não ter fim e que transpõe os limites do humano. Perceba-se, contudo, um detalhe sutil, mas muito pertinente: d. Pedro II legara à
} 
No que diz respeito ao caráter do imperador, assim como aos eventos ligados a suas práticas pessoais, o livro é pormenorizado e minucioso. Datas, horários, locais, personagens, genealogias; neste texto, apesar da brevidade, tudo tem seu lugar, tudo é informado ao leitor. As festas e celebrações, por exemplo, são comentadas quase que com perícia fotográfica. Está-se lidando, assim, com uma narrativa que, através do detalhe e da referência aos mínimos eventos, tenta criar um lugar de verdade; através do cuidado na descrição dos fatos, exalta o personagem que se quer descrever de forma grandiosa. Mais que isso, a certa altura, boa parte da obra é dedicada à reprodução de cartas, pertencentes ao arquivo do conselheiro José Antônio Saraiva, escritas pelo monarca e de anotações que d. Pedro II fez no livro de Tito Franco de Almeida, $O$ conselheiro Francisco José Furtado. É uma forma de documentar, de maneira concreta e infalível, a argúcia e inteligência do imperador. Como diz o autor, com a leitura dessas anotações, pode-se apreciar, "nas suas expressões íntimas, o caráter desse príncipe, digno sem dúvida das palavras de Renan, referindo-se a Marco Aurélio: 'Un moment, grâce a lui, le monde a été gouverné par l'homme de meilleur et le plus grand de son siecle"". Com sua narrativa e referências documentais, o autor estrutura uma obra que demonstra como, ao longo desse reinado de cinquenta anos nada pode, "sem quebra da verdade", ser dito de muito grave contra o imperador; "mesmo na expansão íntima, jamais deixou transparecer sentimentos menos comedidos. Quando muito, da linha de imperturbável serenidade que se traçara, ressumava justo pessimismo". ${ }^{215}$ A intenção, a todo o momento, é exaltar a excepcionalidade de d. Pedro II, principalmente em face de um povo ainda jovem e inseguro, que precisa ser instruído e conduzido.

Após comentar acerca da pujança intelectual do monarca, um aspecto que não deixa de ser tratado, para o bem ou para o mal, por nenhuma apreciação biográfica, Fleiuss parte para outro tema recorrente: a força moral do imperador, "essa grandeza d'alma que lhe valeu o epíteto histórico de d. Pedro II, o Magnânimo". Segundo o autor, "ninguém elevou mais alto do que ele o prestígio e autoridade e a probidade ilibada na difícil e vasta ciência de governar por meio século a terra brasileira, e fazê-la uma nação opulenta e feliz como a nossa". Sobre esse assunto, note-se que Max Fleiuss vai citar o texto de Carlos Magalhães de Azeredo, sensivelmente a parte em que este diz que d.

posterioridade, através de uma biblioteca pública e do IHGB, este o legitimo herdeiro de seu legado, todos seus livros; deixara aos brasileiros do futuro, portanto, a sua maior riqueza. Ou seja, ao falar da cultura do monarca e exaltá-la, está-se falando não só do imperador, mas também da própria posição de destaque que o IHGB ocuparia na inteligência nacional.

${ }^{215}$ Max Fleiuss. Dom Pedro Segundo. Op. cit., p. 132 e pp. 134-135. 
Pedro II foi, “em todo o significado moral do termo, 'um homem', a quem a posterioridade e a justiça da história apontarão sempre: 'Ecce homo'!’. Um homem magnânimo, evidentemente, figura semelhante àqueles biografados por Plutarco, ou "desses dos quais nos fala Shakespeare, afirmando que, de cada polegada da sua estatura moral, poder-se-ia fazer um grande homem". Novamente vemos referências importantes quando se trata de d. Pedro II; agora, porém, ao invés de temas bíblicos, o autor resgata a cultura clássica e o grande dramaturgo inglês. Dessa maneira, apoiado em todo esse repertório, nosso imperador aparece como um vulto que, em suma e de forma incontestável, "domina largo trecho da História do Brasil”. 216

O livro de Max Fleiuss, como se pode perceber, é breve, leve e se propõe instrutivo. Ao longo da narrativa, quase não há conflitos, tudo corre de forma a beirar o idílico; mesmo quando aparece alguma referência a guerras e motins, os fatos são decorrências de virtudes ou vícios pessoais, é como se o autor os usasse para compor um cenário, uma paisagem que deixe em destaque o monarca, que o coloque em relevo diante de seus contemporâneos. A obra, portanto, apresenta uma visão bastante positivada do imperador e, uma relação direta, da própria história do Brasil. Seu texto tem um interesse unívoco: retomar a memória de d. Pedro II, lançando luz sobre o passado, de forma a dar sentido nacional profundo às mudanças perpetradas no presente. Tudo o que somos, devemos ao segundo imperador; por isso, cultuemos sua memória, olhemos para seu exemplo sem preconceitos de época e ódios políticos. Essa é uma lição a ser ensinada às gerações presentes e futuras, tão suscetíveis a esquecer dos grandes exemplos do passado, tão passíveis de escutar os apelos "dos impenitentes e dos injustos". Apesar de um pouco longa, perceba-se o tom da seguinte passagem:

Após cinquenta anos de reinado de uma das mais prósperas nações do globo, sem que ninguém lhe haja imputado jamais um só ato menos digno, um ímpeto sequer de vingança ou do mais leve ressentimento contra quem quer que seja, deixou o trono pelo exílio, como o assumira a 23 de julho de 1840 , com a alma branca, a fronte erguida, somente aureolada pela velhice e pelo sofrimento, as mãos limpas como a consciência.

Fora ele um desonesto, e ao invés das dificuldades com que teve de lutar em terra do exílio e nos dois anos que sobrevieram, teria falecido não na pobreza honrada que, com a glória do nome, soube legar aos seus descendentes.

Nem se vislumbre nestas expressões a grandiosidade de uma lisonja: ninguém bajula os mortos numa época de individualismo absorvente em que o conflito vital de interesses faz esquecer facilmente o pó dos túmulos.

\footnotetext{
${ }^{216}$ Max Fleiuss. Dom Pedro Segundo. Op. cit., p. 82 e p. 83.
} 
Entretanto, nem a grandeza da morte, nem os reveses do ostracismo superam em d. Pedro II a majestade da estatura moral e a intelectualidade, que os mais célebres homens das ciências e letras do mundo inteiro consagraram. Só os impenitentes e os injustos por anomalia de visão moral, postos em face do límpido cristal de uma consciência histórica inatacável, como a de d. Pedro II, supõem que lhe podem diminuir a memória, consagrada pelos mais célebres vultos de estadistas e sábios, de homens de letras, e de artes do mundo inteiro, tanto do passado como do atual século. ${ }^{217}$

É como um resumo da ópera. Individualismo e anomalias de visão moral, esses os dois maiores inimigos da memória do imperador, um sujeito, por sua vez, tão preocupado com seu povo e tão apegado a rígidos valores morais. São essas deturpações que legam ao esquecimento o "pó dos túmulos", assim como a conduta dos grandes sábios de outrora e a grandeza da pátria. Max Fleiuss elabora uma interpretação norteada pelo interesse nacional, pelas mudanças do presente e pela necessidade de legitimar o lugar do Instituto Histórico e Geográfico Brasileiro. Para isso, recorre aos sábios de várias épocas e aos textos bíblicos, tecendo uma verdadeira epopeia nacional, na qual, desde a colonização, desde que o Brasil era ainda Terra de Santa Cruz, até o atual momento, se desenrolara uma história gloriosa e heroica. D. Pedro II fora o grande dinamizador desse épico, o agente modernizador; esquecê-lo seria olvidar de nossa grandeza e falhar com o destino. Seria, acima de tudo, negar um rei prometido, o rei de uma terra prometida.

\footnotetext{
${ }^{217}$ Max Fleiuss. Dom Pedro Segundo. Op. cit., pp. 43-44.
} 


\section{1. 4. Heitor Lyra: um monumento feito de palavras}

"Se o Imperador não tinha a envergadura de homem de Estado, era apenas nesse sentido: que ele não percebia muito além das grandes necessidades de seu tempo. A visão que possuía das coisas presentes era mais ou menos exata; faltava-lhe, entretanto, a intuição das coisas futuras. Ora, gouverner c'est prevoir, dizia Thiers. Mas o grande serviço que ele nos prestava, não era tanto o de preparar um Brasil de amanhã, mas sobretudo o de consolidar o Brasil do presente, o Brasil do seu tempo; dar-lhe uma estrutura política e social bastante resistente, para que as gerações vindouras pudessem construir o grande edifício que seria o Brasil do futuro, sem receio de vê-lo um dia por terra. Ele era, neste particular, um dos grandes consolidadores dos alicerces da nossa nacionalidade, que uma política colonial sem método e sem finalidade e um Primeiro Reinado turbulento, nos legara incompletos e já abalados. Era essa a tarefa civilizadora, a grande obra que conscientemente ou inconscientemente nos prestava o Imperador".

Heitor Lyra, em História de D. Pedro II

Entre 1938 e 1940, Heitor Lyra publicou, um a cada ano, os três volumes de sua História de D. Pedro II: Ascensão, Fastígio e Declínio. Apesar do caráter monumental - somados os três livros, são mais de mil páginas -, e da visão positivada que acaba por elaborar, dentre as biografias de d. Pedro II, esta é uma das mais rigorosas no que diz respeito à documentação, além de ser, com sua redação articulada, uma das mais bem escritas. O que mais chama a atenção, contudo, não é o tamanho, nem a capacidade narrativa do autor, e sim a visão que lança sobre o biografado; mesmo sendo elogiosa, não deixa de ser pontuada por algumas observações que podem ser entendidas, no fundo, enquanto comentários tendentes ao negativo. Essa é uma postura que, em meio às flores sem espinhos, raramente acontece; quando soe ocorrer, é algo menor e enviesado. No texto de Lyra, entretanto, não há nenhuma exaltação gratuita do personagem - o que, talvez, numa interessante estratégia interpretativa, acabe por evidenciar ainda mais a excepcionalidade do biografado.

Para entender essa característica da obra, é preciso conhecer a história por trás dela, de sua concepção e elaboração. Heitor Lyra era formado em direito e, ainda muito jovem, em 1916, assumiu o cargo de adido à Secretaria de Estado das Relações Exteriores. De acordo com Alexandre Eulálio, o novo funcionário causou admiração nos seus colegas; no prefácio à edição de 1977, o crítico diz o seguinte: “indiferente ao 
espanto dos funcionários do Itamaraty, o bacharel recém-egresso do seu Direito pede para ser lotado na Seção do Arquivo". O espantoso disso é que, nesse tempo, "a Seção do Arquivo não era apenas a menos brilhante mas ainda a mais, literalmente, empoeirada de toda a Casa". ${ }^{218}$ Foi como responsável por essa seção que Lyra imergiu no estudo da história brasileira e fez publicar diversos artigos, dentre os quais se destacam aqueles que, coerente ao seu ofício, tratam das relações internacionais brasileiras.

A pesquisa sobre d. Pedro II, mais especificamente, surgiu no horizonte quando foi lotado, em 1928, na cidade de Roma. Cerca de quatro anos, ele irá servir na embaixada junto à Santa Sé; lá conviveu, diretamente, com Carlos Magalhães de Azeredo, seu chefe imediato e, como já abordado nesta pesquisa, eminente admirador do monarca. A crer em Alexandre Eulálio, Lyra teria se despertado para sua grande obra numa tarde do ano de 1930, um dia em que Magalhães de Azeredo ofereceu, ao filho primogênito da Princesa Isabel, o senhor Pedro de Alcântara de Orléans e Bragança (1875-1940), uma recepção na embaixada brasileira. Foi nessa ocasião que, de acordo com Eulálio, o jovem secretário, conversando amigavelmente com o neto de d. Pedro II, "comentou o fato de que, na sua opinião, a figura e a obra do monarca eram então quase desconhecidas na própria terra dele; isso apesar dos cinquenta anos de reinado e das comemorações em sua homenagem que, de tanto em tanto, aí tinham lugar”. Na sequência, Lyra teria completado da seguinte forma: era "mais necessário do que nunca o aparecimento de obra séria, consistente, que abordasse como um todo o estadista e o homem; um tal livro permitiria a avaliação da presença de um e outro em mais de meio século de história nacional". ${ }^{219}$ Dito isso, o filho da princesa Isabel, respondendo aos comentários, teria incitado o secretário a, ele mesmo, realizar tal empreitada; para isso, prometia livre acesso aos arquivos da família imperial, guardados em sua propriedade, o Castelo d'Eu.

Esse é o começo da história; um jovem secretário de embaixada, sob a chefia de um admirador notório de d. Pedro II e instigado, pelo neto do próprio imperador, a escrever uma biografia. Poderia culminar em mais um texto transbordando de emoção e admiração; em uma verdadeira exacerbação da memória, exaltação absoluta e gloriosa do monarca. No entanto, História de D. Pedro II é um livro que escapa dessas fáceis

\footnotetext{
${ }^{218}$ Alexandre Eulálio. “O ofício de escrever de Heitor Lyra”. In: Heitor Lyra. História de Dom Pedro II. Volume I: Ascensão (1825-1870). Belo Horizonte: Editora Itatiaia; São Paulo: Edusp, 1977, p. I.

${ }^{219}$ Alexandre Eulálio. "O ofício de escrever de Heitor Lyra". Op. cit., p. III.
} 
armadilhas. Perceba-se, nesse sentido, na resposta que, segundo Eulálio, Heitor Lyra teria dado ao neto do imperador, a perspicácia acerca da duplicidade que envolve a memória de d. Pedro II; era preciso, segundo o pesquisador, ressaltar o estadista e o homem. Isso revela que o autor, de certa forma, sabia estar lidando com um personagem complexo, que precisava ser abordado por suas características específicas e humanas e, ao mesmo tempo, ser enquadrado em seu contexto e posto em diálogo com aqueles que o cercavam. Se d. Pedro II deve, evidentemente, ocupar o lugar de destaque na trama, isso, porém, não significa que ele deva sufocar o entendimento da história como um todo. Com razão, Alexandre Eulálio ressalta que, no texto de Heitor Lyra,

existe sempre um contraponto cuidadoso, alerta, sistematicamente organizado, entre análise e descrição, perfil e vista de conjunto. Assim, mais do que simples vida do Imperador a obra se torna verdadeira biografia do Segundo Reinado, um panorama complexo e orgânico, em que a personagem central firma a linha dos acontecimentos, contracenando com os mais diferentes aspectos, problemas e questões do momento. ${ }^{220}$

Antes de adentrar o texto propriamente dito, um fato salta aos olhos: o autor - a exemplo do que fizera, em 1929, Carlos Sussekind de Mendonça, só que por motivos diametralmente opostos (a obra de Mendonça será analisada em seção futura desta dissertação) - dedica a obra a seu pai, A. A. Pereira de Lyra. Este fora deputado provincial durante o Império, eleito "pelos liberais pernambucanos"; posteriormente, membro da Assembleia constituinte de 1891 e deputado federal por mais de vinte anos. Conforme salientado na dedicatória, foi na companhia de seu pai que o autor aprendeu, "desde a infância, a respeitar e a fazer justiça a Dom Pedro II". Ou seja, o pessoal e o histórico se tocam nessa obra; o pai e o imperador, ambos, são exemplos a serem rememorados e admirados. Pela carreira da figura paterna, um político entre o Império e a República, talvez seja possível, também, entender porque, apesar de admirador de d. Pedro II e tendente a uma interpretação do Segundo Reinado pelo viés conservador, Heitor Lyra não faz um julgamento da República, não tece, em seu texto, comentários evidentemente embasados por uma perspectiva monarquista. Fazer isso, afinal, seria colocar em risco a posição política ocupada pela pessoa a quem a própria obra é dedicada. No final do terceiro volume, é reveladora a forma como Lyra trata do suposto republicanismo de d. Pedro II; essa preferência, às vezes manifesta na vontade de preferir ser presidente a ser monarca, não era esnobismo; refletia, em realidade, "a tendência, que sempre existiu no Imperador, de se despregar, ao menos em imaginação,

\footnotetext{
${ }^{220}$ Alexandre Eulálio. "O ofício de escrever de Heitor Lyra”. Op. cit., p. V.
} 
de uma posição que, pela tradição histórica e significação política, era a menos compatível com a sua natureza patriarcal e inteiramente desambiciosa”. Era, portanto e note-se a recorrência, bastante produtiva, de uma política apolítica e do desapego pelo poder -, "um desencantado da coroa que o destino lhe pusera na cabeça". Daí porque podia dizer, com certa tranquilidade, "formas de governo, escreveu certa vez o Imperador, são meras questões de estética!". ${ }^{221}$ A tônica da biografia é a mesma desse último comentário: quer-se evidenciar d. Pedro II enquanto um exemplo de governante e enquanto um consolidador da nacionalidade, o que está além do regime político adotado. Formas de governo são meras questões de estética; grandes governantes, aqueles que merecem ser louvados e rememorados, não.

Nos agradecimentos, Heitor Lyra ressalta que a biografia de d. Pedro II foi escrita, desde 1930, quase que integralmente na Europa, principalmente em Roma. Foi aí, na capital italiana, que pode utilizar, a fim de realizar suas pesquisas, a biblioteca pessoal de Carlos Magalhães de Azeredo. A admiração por Azeredo, apesar de suas obras serem bastante distintas em vários aspectos, tanto formais quanto temáticos, era grande; assim se refere o autor ao seu chefe: "O Sr. Magalhães de Azeredo é um dos que melhor conhecem atualmente esse longo período da nossa história [o Segundo Reinado]; e o belo perfil que traçou do último Imperador é, sem favor, uma obra-prima de observação e de estilo". ${ }^{222}$ Outro agradecimento, evidentemente, vai para Pedro de Orléans e Bragança, que acolheu o autor em seu castelo, na França, e franqueou-lhe o arquivo da família imperial, no qual pôde consultar inestimável documentação, muita da qual permanecia inédita.

A volumosa obra de Heitor Lyra, mais do que uma história de d. Pedro II, como vem no título, é uma biografia do Segundo Reinado, de acordo com a caracterização de Alexandre Eulálio. O monarca, nela, aparece enquanto um personagem envolto por intrigas; a sua capacidade de decisão e ação, apesar de sempre afirmada, é mediada por todos aqueles que o cercam. O imperador, assim, nunca está sozinho, jamais é tomado como elemento isolado. No que diz respeito aos seus primeiros anos, o que chama atenção é o destaque dado por Heitor Lyra à pessoa de Da. Mariana de Verna, aia do jovem príncipe. É com a história dela, inclusive, que o livro se abre; conta-se acerca de

\footnotetext{
${ }^{221}$ Heitor Lyra. História de Dom Pedro II. Volume III: Declínio (1880-1891). Rio de Janeiro: Companhia Editora Nacional, 1940 (Coleção Brasiliana, vol. 133-B), pp.257-259.

${ }^{222}$ Heitor Lyra. História de Dom Pedro II. Volume I: Ascensão (1825-1870). Rio de Janeiro: Companhia Editora Nacional, 1938 (Coleção Brasiliana, vol. 133), p. 16.
} 
sua família, de sua vinda de Portugal para o Brasil e, finalmente, do convite feito por d. Pedro I: queria que fosse a encarregada de seu filho. Da. Mariana, assim, é a via pela qual o autor vai perscrutar a vida intima do jovem; além disso, no capítulo II, “José Bonifácio, tutor de Sua Majestade”, ela vai servir de contraponto ao tutor. É a aia quem se preocupa com o jovem monarca, lhe dá alento e atenção; Bonifácio, por sua vez, estaria mais preocupado com os lances da conturbada política imperial - nos anos da Regência, segundo o autor, "tudo concorreu para tornar essa época a prova de fogo da nacionalidade em formação" 223 -, o que lhe fazia descuidar dos deveres mais sensíveis de tutor. Nesse capítulo, aliás, Lyra vai esforçar-se, cerca de três dezenas de páginas, usando para isso de documentação, notadamente diplomática, por combater o mito do patriarca da independência. Tomando Bonifácio por suposto herói, trata-o de "oportunista e aderente" - "como bom oportunista, preferia ficar na expectativa, para ver em que davam as modas" -, cuja atuação no movimento de emancipação do Brasil teria sido modesta, obscura e, até mesmo, nula. Bonifácio era um homem que levava Portugal no coração, lá vivera e se formara; fizera amigos e estabelecera laços. Não se devia estranhar, então, sua posição duvidosa em 1822; não haveria motivo "por que emprestar ainda hoje a José Bonifácio um papel que não teve nos acontecimentos que nos levaram a nos separar de Portugal. A lenda do Patriarca, sobre ser contrária a todos os fatos históricos, é ridícula". ${ }^{224}$ A crer em Lyra, Bonifácio era marcado por um pendor absolutista e antiliberal, rescaldo do século XVIII, que era, em verdade, o seu século; tinha, além do mais, uma necessidade constante de prestígio, o que lhe fazia atacar, de maneira feroz e ácida, aqueles que o estavam deixando à sombra.

Interessante notar como, ao desbancar o mito do patriarca, Heitor Lyra ataca os outros membros da família dos Andradas. Todos eles "não passavam de oportunistas, liberais hoje e conservadores amanhã, conforme conviesse às suas políticas e às possibilidades de alcançarem ou não o poder, todo o verdadeiro escopo de suas ambições". ${ }^{225}$ Eram, portanto, representantes de uma gama de políticos interesseiros e

\footnotetext{
${ }^{223}$ Heitor Lyra. História de Dom Pedro II. Volume I: Ascensão (1825-1870). Op. cit., p. 55.

${ }^{224}$ Heitor Lyra. História de Dom Pedro II. Volume I: Ascensão (1825-1870). Op. cit., p. 72 . O tom sempre é duro com o patriarca: "Pergunta-se: que amor podia ele ter a essa terra [o Brasil], que quase não conhecia, onde não tinha amigos e era por assim dizer desconhecido, longe da qual passara quase toda a existência, identificado com a vida, os costumes e a gente de Portugal? O velho Reino, pelo contrário, fora até então a sua verdadeira pátria. Ali desembarcara quase uma criança, fizera os estudos, desenvolvera o corpo e o espírito, criara o círculo de amigos. Mas sobretudo fora o país que o amparara materialmente, de quem recebera sempre os proventos para a manutenção. Nesse particular, José Bonifácio aparece como o verdadeiro cabide de empregos portugueses”, p. 68.

${ }^{225}$ Heitor Lyra. História de Dom Pedro II. Volume I: Ascensão (1825-1870). Op. cit., p. 183.
} 
imorais, emblemáticos daquilo que Lyra queria denunciar enquanto uma forma negativa de fazer política. Assim, ao tratar do tema da maioridade, por exemplo, o autor nega a versão de que d. Pedro II, ao ser consultado, teria assentido e requisitado o poder, desde que "este negócio fosse realizado pelos Andradas e seus amigos", antes de atingir os dezoito anos. Lyra faz isso exatamente porque, em momento tão angular da história nacional, não quer dar preponderância aos irmãos de Bonifácio. $\mathrm{O}$ curioso é que, na tentativa de fazer isso, não se preocupa em desmentir algo tão falado pelos apólogos do monarca: a sua predisposição precoce a governar. No entanto, ressalta como essa predisposição se dava de forma inocente, alheia aos conflitos de interesses, sem ambições e era controla pela rotina de estudos:

Dom Pedro II era então um rapazola de pouco mais de 14 anos de idade, sem nenhuma ambição pessoal, e avesso, por índole e por educação, a tudo quanto fossem golpes de audácia ou conjuras parlamentares. Suas preocupações iam então para os estudos, que lhe absorviam, pode-se dizer, todas as horas. Andava quase que inteiramente alheio às competições políticas que se teciam em torno de sua pessoa. Os debates no Parlamento, a agitação nos clubes e nas ruas, as polêmicas na imprensa, tudo isso mal lhe chegava aos ouvidos. E se, alguma vez ouviu conversarem no Paço a respeito da antecipação da maioridade, não fora solicitado nem dera jamais opinião sobre o assunto. Mesmo porque não a tinha. ${ }^{226}$

O assentimento do monarca, segundo nosso autor, ocorreu somente após ouvir conselhos do tutor Itanhaém e do preceptor Frei Pedro. Ao invés de uma decisão firme, do audacioso quero já, o que tivera lugar fora um tímido sim, proferido por necessidade e urgência, posto que estava ameaçada a ordem pública. O imperador, nessa concepção, subira ao trono porque, diante das disputas que medravam ao redor do país, todos o viam como "o único recurso possível de salvação"; porque, conforme ressalta Lyra, havia "a necessidade urgente de enterrar-se para sempre a Regência, antes que, por causa dela, lavrasse o incêndio de uma grande revolução no Brasil, da qual a mais séria das consequências seria o desmembramento da grande pátria". ${ }^{227} \mathrm{O}$ jovem monarca seria, seguindo essa lógica, o único capaz, mesmo que de forma indireta, de serenar os ímpetos e reorganizar, com tranquilidade e legitimidade, ordem e paz, a nação sob o Segundo Reinado. Diante de sua coroa, tanto os liberais exaltados quanto os governistas, aceitariam diminuir suas disputas. Sem dúvida, muitos, tais como Evaristo da Veiga, Feijó, Bernardo de Vasconcelos e Olinda, contribuíram para "fundar a ordem civil em um país que iniciava a sua vida de nação independente", que lutava contra a

\footnotetext{
${ }^{226}$ Heitor Lyra. História de Dom Pedro II. Volume I: Ascensão (1825-1870). Op. cit., pp. 126-127.

${ }^{227}$ Heitor Lyra. História de Dom Pedro II. Volume I: Ascensão (1825-1870). Op. cit., p. 130.
} 
"onda de anarquia" que dominava o país de norte a sul; todos foram "obreiros da nossa nacionalidade". Contudo, elemento neutro, puro e transcendente, "havia acima deles e de todos, acima das paixões, acima dos despeitos, acima das malquerenças, das competições partidárias e das ambições pessoais, a doce figura do Imperador menino, do pequeno Monarca, do pupilo da nação". Era como "a luz salvadora do farol, que nas noites tormentosas guia e acolhe os navegantes desamparados. Todos o fitavam com uma profunda esperança. Todos lhe queriam bem". ${ }^{228}$ Era preciso, então, cuidar desse jovem tão especial, cercá-lo de cuidados; esse órfão se tratava, acima de tudo, de um símbolo da nação, uma garantia de unidade e harmonia. Aqui, justamente no momento da maioridade, surge bem nuançada a perspectiva de Heitor Lyra: mesmo não podendo intervir diretamente nos fatos, d. Pedro II era uma presença fundamental. Não dominava a cena, porém tampouco deixava de atuar e ser necessário; essa característica, que se manifestava já no início do seu reinado, vai ser uma constante ao longo dos próximos quase cinquenta anos.

Sobre os primeiros momentos do Segundo Reinado, Heitor Lyra comenta acerca da retidão de caráter do jovem monarca, da dificuldade em decifrar-lhe os sinais e intenções; era um verdadeiro enigma, "que despistava a todos sem se deixar descobrir por ninguém". Diante das tormentas vividas no passado recente, todos se colocavam questões: o que esperar do jovem, será que vingariam todas as suas potencialidades? Seria ele - e esses são os riscos da transcendência em política - "um rei déspota e sanguinário com Luís XI? Um imbecil como Afonso VI? Um soberano pachorrento e maleável, mas no fundo emperrado, com o avô João VI? Um estabanado como o pai?”. As respostas para essas perguntas não eram simples; somente o tempo se encarregaria delas. Além disso, ressalte-se que, mesmo tendo sido elevado ao poder como uma garantia de paz, o jovem monarca viveu, nos primeiros tempos de seu reinado, um cenário de sérias disputas políticas, das quais não conseguia fazer pleno juízo. Dessa maneira, quase um gesto de autodefesa, "se recolherá ainda mais em seus sentimentos íntimos"; isso, a crer em Lyra, mais do que devido à timidez ou ao assombro com a repentina posição de imperador, era um sinal do "seu excepcional bom senso, precocemente revelado, bem maior nesse menino de quinze anos do que em muitos velhos estadistas que o cercavam". Afastado de "intrigas e baixas competições", "das

\footnotetext{
${ }^{228}$ Heitor Lyra. História de Dom Pedro II. Volume I: Ascensão (1825-1870). Op. cit., pp. 56-57.
} 
facções e da politicagem", vivia isolado, "em sua verdadeira posição de rei constitucional", 229

Importante notar que, na biografia de Heitor Lyra, os anos entre 1840 e 1847 são de aprendizado político para d. Pedro II; nesse período, quem esteve junto dele foram figuras pertencentes àquilo que o autor chama de facção áulica; pessoas próximas, de dentro do Paço, cujos representantes mais destacados eram Aureliano Coutinho e Paulo Barbosa da Silva. O primeiro é o que ganha maior destaque na biografia; esteve constantemente interferindo, no que diz respeito às grandes decisões, junto ao jovem. A evolução política do imperador, nesse sentido, vai se dando na medida em que ele consegue detectar os interesses por trás daqueles que o cercam e, a partir dessa consciência, se tornar cada vez mais autônomo. Tanto é assim que, quando a intromissão da gente do Paço nos assuntos públicos se tornou inoportuna e ganhou contornos de escândalo, o imperador decide-se - e este é um tema fundamental na linha de raciocínio de Heitor Lyra - "pelo que, desde algum tempo, era já anseio de alguns de nossos homens públicos: a criação de uma presidência do Conselho de Ministros. Na história política do Reinado, ela tem grande significação: assinala o fim do professorado de Aureliano". ${ }^{230} \mathrm{O}$ monarca começa, assim, a esboçar seus primeiros passos políticos. Até esse momento, o nosso autor, apesar de dar crédito a alguns dos políticos que cercavam d. Pedro II, não transmite uma imagem plenamente confiável de nenhum deles; o imperador surge, no mais das vezes, como um suporte no qual todos, em busca de legitimidade, tentavam se escorar. A sensível mudança no tom da obra se dá a partir do capítulo VIII do primeiro volume, não sem motivo intitulado "Primeiras afirmações de autoridade". Somente com o "ostracismo de Paulo Barbosa", o "afastamento de Aureliano Coutinho de toda ingerência nas organizações ministeriais" e "com a criação da presidência do Conselho, que o Imperador obtém a sua completa emancipação". Ao concretizar essas medidas e se livrar de interferências áulicas, que passavam já a ser empecilhos, "seu caráter toma logo uma nova feição. Torna-se mais expansivo, mais comunicativo. Começa a perder aquele véu suspeitoso e retraído que o cobria". ${ }^{231}$

\footnotetext{
${ }^{229}$ Heitor Lyra. História de Dom Pedro II. Volume I: Ascensão (1825-1870). Op. cit., p. 143, p. 151 e p. 153.

${ }^{230}$ Heitor Lyra. História de Dom Pedro II. Volume I: Ascensão (1825-1870). Op. cit., p. 197.

${ }^{231}$ Heitor Lyra. História de Dom Pedro II. Volume I: Ascensão (1825-1870). Op. cit., pp. 278-279. Ainda sobre a criação da presidência do Conselho, Heitor Lyra comenta que tal medida podia não resolver, de pronto, "todos os problemas de direito público, tanto de ordem constitucional como de ordem política e administrativa. Mas era certo que iria atenuar-lhes os pontos de maior atrito; tiraria às organizações ministeriais o seu caráter clandestino e improvisado; unificaria o pensamento político e administrativo dos
} 
Um caso emblemático dessas "primeiras afirmações de autoridade", muito por conta das idas e vindas envolvidas no caso, é a volta de Olinda ao poder, em setembro de 1848, quando foi nomeado para o posto de chefe do Conselho; esse foi, também, de acordo com Lyra, o primeiro momento em que se falou de abuso do poder pessoal. $\mathrm{O}$ certo é que, na lógica do autor, com esta atitude, o jovem monarca estabelece o fim do liberalismo radical, cujo último ato se dera, nesse mesmo ano, em Pernambuco, e dá o primeiro passo no sentido da consolidação de uma política eminentemente nacional. Para fazer isso, não haveria outro recurso senão apelar para o "elemento conservador", pois

havia ali um punhado de homens de valor, com passado político intacto, e cujas políticas exprimiam, nesse momento, o anseio das classes laboriosas da nação, de todos os verdadeiros patriotas ou todos quantos desejavam entrar definitivamente numa era de paz, de ordem e trabalho.

Dentre esses homens, Olinda era, sem dúvida, o principal, o vulto mais eminente, "nenhum outro o valia em autoridade. Por sua idade, por seu passado, por seus serviços, por todas as suas qualidades, ele se distanciava de todos os demais". ${ }^{232}$ No entendimento de Lyra, portanto, a criação da presidência do conselho, assim como a reentrada em cena de Olinda, foram fatores de estabilidade política, a primeira grande conquista do monarca que começava a se emancipar. Ao comentar esses fatos, o autor deixa transparecer, de forma mais evidente, o seu posicionamento em relação à política do Segundo Reinado: "de tudo isso podia-se tirar uma conclusão: que a entrega do poder aos conservadores estava na ordem natural das coisas”. Dessa forma, não havia como culpar "o Imperador da inversão que se operava na política do país, com a volta ao poder de Olinda e dos maiorais do partido conservador”. Esta era, em suma, a única solução para a crise de 1848, rescaldo dos anos de Regência, que todos queriam superar. Além disso, o autor justifica tal intervenção ao dizer que, mesmo que d. Pedro II tenha dado seu assentimento a essa solução, "nada prova, entretanto, que tenha sido ele o seu inspirador, que tenha partido dele a ideia dessa reviravolta política". ${ }^{233}$ Através dessas palavras, Lyra faz uma leitura muito habilidosa dos meandros políticos do inicio de Segundo Reinado, pois dá crédito ao monarca, mas jamais o compromete completamente. É uma forma, por assim dizer, de dar sentido ao arranjo entre política e

Gabinetes; exprimiria uma concessão ao sentimento parlamentarista da nação; e, sobretudo, cobriria a Coroa dentro do mais rigoroso espírito da Constituição", p. 294.

${ }^{232}$ Heitor Lyra. História de Dom Pedro II. Volume I: Ascensão (1825-1870). Op. cit., p. 299.

${ }^{233}$ Heitor Lyra. História de Dom Pedro II. Volume I: Ascensão (1825-1870). Op. cit., pp. 301-302. 
apolítica que permeia a biografia: ao mesmo tempo em que se coloca o personagem no epicentro das ações, se evidencia que ele, em si, não é propriamente o centro dessas mesmas ações. Assim, reafirmam-se, sem que se possa julgar o biografado, as qualidades do imperador, os seus traços de espírito.

A crer em Lyra, a primeira manifestação efetiva, clara e firme do monarca teria sido, curiosamente, a demissão do próprio Olinda, isso no ano seguinte, em 1849 , ocorrida por conta da política a ser assumida na região do Prata. O dilema, segundo o autor, era o seguinte: guerrear ou ser diplomático com Rosas? Olinda, mesmo não se iludindo com as intenções do líder argentino, teria divergido do resto de seu gabinete, que não queria mais contemporizar e, sem mais acordos, apelar para a força. A fim de bloquear a "reconstrução do Vice-reinado do Prata", o grande sonho de Rosas, a única alternativa era partir para o combate. $\mathrm{O}$ imperador, mesmo sendo um partidário da paz, teve de contrariar o chefe do gabinete. No entanto, essa era uma decisão complicada, que colocava em questão os seus ideais. No que diz respeito à política interna, sua divisa era "nada de violência" - "com ela governará durante cinquenta anos uma nação de insubordinados". Com relação à política externa, "seus propósitos pacíficos e conciliadores eram ainda mais decididos. Ele nada ambicionava para o Brasil. Entendia que o Brasil se bastava a si mesmo". Porém, não se resguardou diante dos interesses e atitudes do "ditador argentino"; daí a opção em apoiar os ministros, e não o chefe do gabinete. Isso é uma evidência de que não existia mais "o menino tímido", "baixo e atarracado, silencioso, suspeitando de tudo e de todos" de quem Olinda fora regente; agora, era "um homem já formado, senhor de si, alto, de barbas longas, olhar aberto e atitudes decididas. Era, em suma, um homem”. A demissão do grande vulto conservador - e isso só vem comprovar, no escopo da narrativa, como o monarca era apartidário -, marca, portanto, uma época no Segundo Reinado e na vida de d. Pedro II: "é a sua primeira vontade, afirmada sem rebuços nem subterfúgios". 234

À época, outro assunto ganhava claros contornos na política nacional: o fim do tráfico negreiro. A essa questão o imperador deu todo seu apoio. Sobre isso, nosso autor diz que "ele nunca pôde ocultar a repulsa que lhe causavam os traficantes de escravos", que "manifestava abertamente o pensamento, sem nenhuma preocupação de poupar fosse a quem fosse"; já dissera, até mesmo em uma sessão do Conselho de Estado,

\footnotetext{
${ }^{234}$ Heitor Lyra. História de Dom Pedro II. Volume I: Ascensão (1825-1870). Op. cit., p. 304, p. 307 e p. 311.
} 
"quando se levantaram ali certas objeções a essa sua atitude desassombrada", "que preferia perder o trono, a tolerar a continuação do tráfico de Negros". Uma repulsa, portanto, completa, "antipatia visceral, que ele guardaria pelos anos vindouros, contra todos quantos se tinham envolvido no degradante comércio". Heitor Lyra aproveita-se da oportunidade para reafirmar uma imagem superior do monarca, a sua diferença em relação aos demais políticos, sua transcendência pautada na moral e na civilização: "a condescendência que nesse particular sempre tiveram os homens políticos, mesmo aqueles tidos então ou posteriormente como abolicionistas, ele nunca a teve". ${ }^{235}$ Notese, além disso, que, no que diz respeito ao fim do tráfico, Heitor Lyra não tece maiores comentários; é um tema que fica um tanto quanto em aberto. Ressalta, de modo geral, a aversão do imperador à prática do trafico negreiro e algumas das medidas tomadas no sentido de coibi-lo; comparado a outros temas, contudo, é um dos menos perscrutados e analisados pelo autor. Ao invés disso, aproveitando o mote das críticas ao tráfico, prefere retomar comentários acerca das características e virtudes de d. Pedro II. Comenta que, a princípio, "com seu feitio retraído e suspeitoso, o jovem Imperador não é popular". No entanto, com o passar dos anos, "seu feitio democrata, despido já, inteiramente, de qualquer veleidade de mando ou sentimento aristocrático, seduzia francamente a todos". Começava a ser visto, em sua despretensão e aversão "a qualquer espécie de esnobismo", com certo respeito. Com isso, se, por um lado, começava a capturar atenção da plebe, por outro, não era querido pelos políticos que o cercavam; sobre estes últimos, Lyra ressalta que o imperador começava a se tornar incômodo, pois os tinha "sob seu controle", continha-os "em seus excessos partidários, em suas querelas políticas, polindo-lhes as arestas e dando-lhes, por vezes, lições de moral política”. D. Pedro II, assim, não era, na definição do autor, um político no sentido estrito da palavra. Não dava apoio a nenhum dos partidos, não tinha preferências; "trata os dois no mesmo pé de igualdade. Suas simpatias ou antipatias vão indistintamente para os dois partidos". E é justamente essa atitude sóbria e independente o que lhe garantiu autoridade para, um fruto sensato do pensamento augusto, fomentar e pleitear, “junto aos políticos, em 1853, uma trégua geral nas lutas partidárias, e obter deles a

\footnotetext{
${ }^{235}$ Heitor Lyra. História de Dom Pedro II. Volume I: Ascensão (1825-1870). Op. cit., pp. 324-325.
} 
formação de um Governo de união nacional, que congregue em torno de uma mesma bandeira gregos e troianos, liberais e conservadores". 236

O imperador - em novo exemplo de abnegação -, a princípio um grande entusiasta da política de conciliação, teria sido, de acordo com Lyra, um dos primeiros a, a partir do momento em que ela passou a ser entendida enquanto corrupção e mistura de interesses, dela descrer. Em 1856, com a morte repentina de Paraná, em decorrência da febre amarela, a conciliação, já bastante criticada, perdia seu grande coordenador; o próprio termo, em si, ficava vazio de significado - "passara a ser uma palavra que nada mais exprimia, sobre o sentido da qual ninguém se entendia"; "assinalava uma época já vivida e para sempre enterrada". Daí para frente, seguiria em decadência até ser, enfím, finalizada pelo monarca, em 1859. Contudo, de acordo com o autor, é preciso fazer justiça à Conciliação, pois foi com ela que se diluiu, definitivamente, o espírito revolucionário dos anos anteriores; com ela se consolidou a paz e o regime constitucional. Além do mais, no seu escopo, pela valorização do interesse público ao invés do partidário, se "preparou um punhado de homens novos para o Governo do país". ${ }^{237}$ Interessante notar que, no entendimento de Lyra, esse seria o momento no qual d. Pedro II poderia ter se consolidado plenamente, isolando-se no poder e assumindo a posição de um governante ditatorial; no entanto, "faltavam ao Imperador todos os atributos de um ditador". Tinha repulsa por tudo que "fosse prepotência", "não compreendia nem aceitava nada que não fosse dentro do espírito e da letra da Constituição. Tinha por esta um verdadeiro culto. Era para ele um dogma infalível e indiscutível", 238

Outro tema que merece destaque no primeiro volume da História de D. Pedro II é a Guerra do Paraguai. A esse respeito, Lyra comenta que "o Imperador não nutrira jamais a menor simpatia pelos caudilhos que infestavam as Repúblicas do Continente". Isso já se fizera notar no caso da demissão de Olinda, quando da guerra contra Rosas. Estes "caudilhos" eram o oposto de tudo o que representava o imperador: "turbulentos, dominados quase exclusivamente pela ambição do mando político, e sempre perigosos para a tranquilidade e segurança de nossas fronteiras". Um exemplo de abnegação e respeito, inimigo da violência e respeitador da Constituição, d. Pedro não podia se

\footnotetext{
${ }^{236}$ Heitor Lyra. História de Dom Pedro II. Volume I: Ascensão (1825-1870). Op. cit., pp. 330-332 e p. 369.

${ }^{237}$ Heitor Lyra. História de Dom Pedro II. Volume I: Ascensão (1825-1870). Op. cit., pp. 357-358.

${ }^{238}$ Heitor Lyra. História de Dom Pedro II. Volume I: Ascensão (1825-1870). Op. cit., p. 347.
} 
curvar a esses flagelos, por isso "timbrou em mantê-los numa linha de respeito para com o Império". Nesse ponto, Heitor Lyra deixa vislumbrar como entendia o monarca enquanto um modelo de civilização e avanço das ideias, algo muito diferente daqueles, "na sua generalidade homens rudes do campo, educados, por assim dizer, no lombo dos cavalos, acostumados, desde o nascer, ao uso da garrucha, e desprovidos da menor noção de moral política". Dessa maneira, ao ser afrontado pela ação de Solano López, não restavam muitas opções ao imperador; novamente, teve de contrariar sua natureza e aceitar o desafio do conflito bélico, "era preciso castigar o autor de um gesto tão contrário à sua índole de homem civilizado e sua natureza visceralmente pacífica". Se a índole de d. Pedro nada tinha de guerreira, era preciso se superar e, em nome do patriotismo e da civilização, adentrar o campo de combate; "quem, como ele, era profundamente patriota, não podia deixar de ter, como tinha, na mais alta conta tais atos de abnegação". ${ }^{239}$ Nas passagens sobre a Guerra do Paraguai, portanto, a imagem de d. Pedro II - sempre tomada em contraste à dos governantes das repúblicas vizinhas ganha ares mais heroicos; em nome da pátria e da civilização, o imperador se dispõe a cometer sacrifícios e superar dificuldades. Diretamente ligado a isso, nos termos formais, a narrativa de Heitor Lyra se tece a partir de traços romanceados, ganha contornos de uma crônica da guerra, na qual se notam o trágico e o ardor do conflito.

Após a rendição de Uruguaiana, muitos acreditavam finda a guerra. Mera ilusão: ela "duraria cinco anos, cinco anos de pesados sacrifícios para todos, e que ficariam, nos anais da história militar do Brasil, como os melhores atestados do patriotismo, do espírito de sacrifício e de heroísmo do nosso povo". O imperador, segundo Lyra, foi um dos poucos que não se iludiu completamente; sua própria presença no Rio Grande do Sul era prova disso; foi ele, mais do que qualquer outro, que, diante das exigências do momento, se dedicou "com maior ardor, com mais entusiasmo, com mais acentuado patriotismo"; "ele foi o grande animador da resistência. Sua atividade desdobrou-se. Fez verdadeiros milagres" ${ }^{240}$. O uso do termo resistência, nesse contexto, é dos mais interessantes; o imperador, de feitio sempre pacato, assumia a dianteira da ação, resistia contra a cegueira daqueles que julgavam a disputa contra López como algo simples e resolvido. O conflito bélico exigia uma superior capacidade de entendimento; era preciso, portanto, se colocar acima de interesses políticos e partidários. Ou seja, a ação

\footnotetext{
${ }^{239}$ Heitor Lyra. História de Dom Pedro II. Volume I: Ascensão (1825-1870). Op. cit., pp. 425-426 e pp. 429-430.

${ }^{240}$ Heitor Lyra. História de Dom Pedro II. Volume I: Ascensão (1825-1870). Op. cit., p. 453 e p. 455.
} 
imanente necessitava da elevação transcendente. Na origem da crise que levaria à queda de Zacarias, percebe-se esta abnegação partidária do monarca; de acordo com Lyra, o imperador, uma personalidade singular, "pela sua posição e alto senso patriótico olhava as coisas por outro prisma, conseguiu, com aquela dose de habilidade que nunca the faltou, desfazer todos os preconceitos partidários do Gabinete”. Ou seja, d. Pedro II, a partir de sua posição, de seu "outro prisma", surge como efetiva consciência da pátria; fez da guerra

não uma questão de facção, como era a tendência dos políticos, mas o que realmente devia ser, uma questão nacional, que interessava indistintamente a toda a nação, e cujo triunfo dependia do concurso de todos os Brasileiros de boa vontade, fossem de que partido fossem. ${ }^{241}$

O texto de Lyra guarda pequenas sutilezas, tais como o uso do termo "resistência" e o emprego desse muito sugestivo "Brasileiros", grafado com maiúscula; no fundo, o que se percebe é que, novamente, emerge um imperador muito acima dos políticos, posto que estes, ao contrário do rei e do povo, seriam os brasileiros com minúscula, não dispostos a levar a luta até os limites necessários.

O problema, e esse é o risco do arranjo, é que a queda do gabinete liberal e a nomeação de Caxias como general das tropas no Paraguai ficariam marcados na história, ao menos naquela que era escrita pelos liberais, como um "golpe de poder pessoal", "um dos maiores atentados da Monarquia no sistema representativo". Esta seria uma visão deturpada; de acordo com nosso autor, esses foram atos arrojados e necessários. Para d. Pedro II, que via a situação acima das rusgas partidárias, "o que cumpria, antes de tudo, era vencer o inimigo estrangeiro, debelar completamente a guerra, isto é, salvar a integridade e a independência do país"; não importavam, então, a posição política do gabinete ministerial e, muito menos, as tendências ideológicas do general em chefe. Dessa forma, "a conservação de Caxias à frente das tropas apresentava-se, portanto, como um caso de salvação nacional". Durante a guerra, mais do que nunca, “d. Pedro teve de se desdobrar no seu papel de árbitro, de acomodador de rivalidades, dos ciúmes e das competições que diariamente se levantavam entre os chefes, civis ou militares". Diante dos desajustes, vaidades e brigas recorrentes, "o Imperador intervinha, tolerante, paternal, apelando para o patriotismo dos chefes, para o bem do país, para os altos interesses da nação". ${ }^{242}$ Chama atenção a maneira como são

\footnotetext{
${ }^{241}$ Heitor Lyra. História de Dom Pedro II. Volume I: Ascensão (1825-1870). Op. cit., p. 465.

${ }^{242}$ Heitor Lyra. História de Dom Pedro II. Volume I: Ascensão (1825-1870). Op. cit., pp.500-504.
} 
tratadas, em oposição, os políticos e o imperador; aqueles são mesquinhos, interesseiros, briguentos e aproveitadores; este, é a superioridade em pessoa, abnegado, cerebral e neutro. É como um adulto responsável em meio a crianças agitadas e imaturas, que brigam por brinquedos ou pelo maior pedaço de um doce.

Assim, com o avanço da guerra, coube ao monarca injetar vigor aos que perdiam o ímpeto, "dar ânimo aos desanimados, dar força aos fracos, reacender a chama amortecida de uns, apelar para o patriotismo de outros". A nomeação do próprio genro, o Conde d'Eu, para liderar as tropas, após a retirada de Caxias, era um exemplo dessa conduta inabalável; era um novo sacrifício, o marido da própria filha assumia a "responsabilidade do período mais ingrato da guerra, o mais inglório, o mais despido de láureas, prestando-se ao papel que a Princesa sua mulher chamava de capitão do mato atrás de López". Heitor Lyra, ao comentar tais fatos, sente a necessidade de explicitar quais seriam os motivos do imperador para, de forma tão imperativa, seguir até o fim em uma "perseguição impolítica, se se pode dizer assim, e que só serviu ou serviu sobretudo para emprestar à memória do caudilho paraguaio uma auréola que esteve longe de merecer". O autor, de pronto, ressalta que muita inverdade foi dita acerca desse caso; a maior de todas era a que se referia a uma suposta afronta à honra pessoal cometida por López, quando este teria pedido a mão de uma das princesas imperiais em casamento. Ou seja, o autor é enfático em negar qualquer envolvimento passional do monarca na guerra; afinal, uma figura de estatura moral tão elevada não podia se envolver e persistir no conflito por motivo banal e fútil. De acordo com Lyra, o que, em verdade, almejava d. Pedro era "uma paz que fosse realmente definitiva, com a vitória do Brasil e a pacificação completa do Paraguai, e que ficasse, ao mesmo tempo, como um exemplo a todo caudilho dos Estados vizinhos, que tentasse repetir contra o Império a triste proeza de López". ${ }^{243}$ Motivo, portanto, que estava muito além de afrontas pessoais e da honra particular. Era em nome de uma paz superior que se lutava até o fim, que se prolongava, mesmo contra diversos indícios, a guerra. Impor a derrota absoluta a um sanguinário e fazer disso um exemplo, este o sentido de uma luta tão encarniçada. A guerra surge aos olhos do leitor, então, como um conflito entre civilização e barbárie, no qual a monarquia brasileira assumia, conduzida pela figura de

\footnotetext{
${ }^{243}$ Heitor Lyra. História de Dom Pedro II. Volume I: Ascensão (1825-1870). Op. cit., p. 509, p. 529 e pp.535-536.
} 
seu imperador, uma posição firme e corajosa. Assim diz Heitor Lyra, não deixando margem para dúvidas:

Quando o desenlace da luta começou, afinal, a tornar-se uma coisa certa, e ficou de antemão assegurada a vitória completa de nossas armas, a preocupação do Imperador foi toda para o destino de López, acuado nas matas pelas forças do conde d'Eu. Solano López era certamente um homem bravo, e disto deu várias provas, sendo a última e a mais impressionante delas a sua própria morte; e tinha, a par disso, outras qualidades não comuns. Mas era sem nenhuma dúvida um sanguinário, um desses tipos degenerados, que a História, infelizmente, está acostumada a encontrar de vez em quando, um pouco em toda parte, mesmo nos países de grande cultura. Foi esse sanguinário, que pelos seus próprios atos se colocara fora da lei natural, que o Imperador quis a todo custo castigar. Ninguém pode dizer, honestamente, que ele desejasse a morte do tirano. A cultura de seu espírito, os princípios cristãos que a alimentavam, a generosidade, sempre grande, de seu coração, como ainda todos os atos de sua vida, tudo nele se revoltaria contra um sentimento menos humano para com o ditador paraguaio. Mas ele exigia o seu castigo, que devia consistir unicamente na deposição e expulsão para fora do país que tanto infelicitava. ${ }^{244}$

$\mathrm{Na}$ lógica interna da obra, esse é o último grande momento, a apoteose do volume primeiro; está consolidada, assim, a Ascensão. Um monarca virtuoso, capaz de ver além dos interesses político-partidários mais imediatos, pautado pela civilização e pelos princípios cristãos; pelas vias do sagrado, da moral e da sabedoria, marca seu lugar na História. Ao sustentar uma guerra que parecia finda há muito, d. Pedro II dá o exemplo, mostra que para ser bom e justo é preciso ser severo e firme. Interna e externamente, colocara-se como figura de relevo; apostando alto em estratégias e lances políticos como a criação da presidência do Gabinete, a Conciliação e a Guerra do Paraguai, por vezes errando, na maior parte das vezes, acertando, conseguiu se afirmar. Não havia dúvidas quanto a isso. Agora, abre-se nova etapa, é a glória, o Fastígio. Inicia-se, na sequência, um novo volume. Como diz Heitor Lyra, logo na abertura do novo tomo: "a terminação da guerra do Paraguai marca o apogeu do regime imperial no Brasil. É a idade de ouro da Monarquia. O Império, pode-se dizer, alcança a sua plena madureza". As instituições nacionais, com "sua natureza conservadora", estavam estáveis e pacificadas; além disso - não sem motivo, a partir deste momento, Lyra assume com notável frequência a primeira pessoa do plural -, gozávamos de boa imagem no exterior:

o requinte de nossa sociedade e, sobretudo, a personalidade inconfundível, frisante, respeitável sob todos os sentidos do nosso Imperador, tudo

\footnotetext{
${ }^{244}$ Heitor Lyra. História de Dom Pedro II. Volume I: Ascensão (1825-1870). Op. cit., pp.540-541.
} 
concorria para emprestar-nos lá fora uma reputação que, exceção dos Estados Unidos, a nenhum outro país da América era dado gozar.

O país se desenvolvia e estava no caminho certo do progresso, "havia como que um renascimento geral”. O modelo de desenvolvimento, como já se fez notar, eram os Estados Unidos; se era impossível igualá-los, pois lá ocorria "a mais formidável transformação material que já se vira", dentro de nossas limitações "dávamos, contudo, o exemplo de um país desejoso de adaptar-se o mais prontamente possível, dentro das condições especiais que eram as nossas, ao temperamento propulsor da época". ${ }^{245}$

Na parte inicial do segundo volume, merece destaque a posição que d. Pedro II ocupa em meio a todas essas inovações. De acordo com nosso autor, tudo o que estava ocorrendo mostrava "que o Imperador, apesar do seu espírito especulativo, estava longe de ser um inimigo do progresso material do país". Mesmo que ele não fosse "um homem audaz" e intrépido, não se pode dizer, a partir dessas características pessoais, "que fosse avesso às tendências progressistas do tempo, nem que procurasse, de qualquer modo, impedir ou estorvar a ação dos Ministros, no sentido de uma maior expansão agrícola, industrial e comercial do Império". Além do mais, era preciso atentar para o fato de que, comumente, nossos homens públicos eram marcados pela negligência no que diz respeito aos "grandes problemas nacionais", pela "falta de continuidade de suas políticas", pela "indolência de muitos, para julgar da soma de esforços precisos para tocá-los pelo bom caminho e chamá-los às verdadeiras realidades do país". Mais do que isso, preconceitos contrários às "empreitadas de largo vulto, que marcavam a evolução material do século", existiam, também, nos "países cultos da Europa". ${ }^{246}$ Ou seja, d. Pedro II estava inserido em um contexto, em uma determinada maneira de pensar que tendia à desconfiança em relação ao progresso; isso, aliado à sua reafirmada retidão de caráter e ao seu pendor de tudo moralizar, por vezes, podia

\footnotetext{
${ }^{245}$ Heitor Lyra. História de Dom Pedro II. Volume II: Fastígio (1870-1880). Rio de Janeiro: Companhia Editora Nacional, 1939 (Coleção Brasiliana, vol. 133-A), pp. 3-4 e p. 13. A respeito dessa idade de ouro da monarquia, é importante ressaltar um aspecto do livro que, infelizmente, não pode ser tratado em profundidade no escopo dessa pesquisa. A parte inicial do segundo volume, principalmente o capítulo II, "A vida na Corte", é um interessante estudo de costumes e modos de vida, uma apreciação da cidade do Rio de Janeiro e de seu cotidiano; algo bem parecido, em alguns pontos, e guardadas as devidas proporções, com os trabalhos que Gilberto Freyre vinha desenvolvendo desde o começo dos anos 1930. Quase nada escapa ao olhar atento de Lyra: alimentação, vestimentas, hábitos de consumo, inovações feitas na paisagem urbana, divertimentos, etc. Tudo entra na sua apreciação, na sua descrição material do fastígio de d. Pedro II.

${ }^{246}$ Heitor Lyra. História de Dom Pedro II. Volume II: Fastígio (1870-1880). Op. cit., pp. 14-15, pp. 1920 e pp. 24-26.
} 
fomentar entendimentos equivocados. Como diz Lyra, referindo-se à personalidade de d. Pedro II:

um homem como ele, avesso ao luxo, inimigo do supérfluo, arredio a toda preocupação de grandeza, que tinha o maior desprezo pelo dinheiro, viesse de onde viesse, fosse qual fosse seu modo de aquisição, e com mais forte razão se ilícita - que admiração, mesmo que simpatia podia nutrir pelos fazedores de fortuna rápida, que são em geral os homens de grandes negócios, os iniciadores de grandes empreendimentos práticos? Não estará aí a explicação de seu pouco entusiasmo pelos projetos grandiosos do visconde de Mauá?

Sobre a relação do monarca com Mauá, Lyra tece interessantes comentários que deixam entrever como a sua interpretação do reinado de d. Pedro II segue um entendimento mais conservador. Segundo o autor, mesmo que se quisesse apresentar Mauá "como um dos grandes consolidadores da unidade nacional", o empresário era, antes de tudo, "um espírito cosmopolita", "o nacionalismo nunca fora uma de suas virtudes - ou de seus defeitos. O conceito de pátria era para ele uma coisa muito relativa, como o é, aliás, em geral, para todos esses homens de grandes negócios". A partir dessas observações, afirma que, "mais que um Brasileiro, ele foi um Americano, um grande Americano, se quiserem”. O Imperador, por outro lado, pela própria função que detinha, "pela serenidade de suas atitudes, pelo seu alto senso patriótico, foi o agente propulsor da centralização, quer dizer, da unidade nacional, solidificada pela espada e pelo bom senso de Caxias, aquele bom senso que Cotegipe tanto exaltava". ${ }^{247}$ Há, aqui, um contraste, dos mais reveladores, entre unidade nacional e internacionalização, centralização e cosmopolitismo. Por mais profícuo que pudesse ser o progresso brasileiro, por mais necessárias que fossem as inovações, a grande obra do imperador - a epígrafe dessa seção mostra isso claramente - era o estabelecimento, firmes e fortes, dos alicerces nacionais. Ao invés de grandes especulações, consolidou as bases para as gerações vindouras, estabilizou o presente para possibilitar o futuro. Esse era o grande legado de d. Pedro II - ao menos o que merecia ser celebrado na virada da década de 1930 para a de 1940 -, algo que só poderia ser feito através de uma centralização, sustentada na política conservadora e, quando necessário, no fio da espada. Dos mínimos detalhes aos grandes assuntos, a "vontade imperial tornava-se então uma realidade”. Ele estava

acima dos homens, pela realeza; acima dos partidos, pela natureza de seu cargo. Pairando bem alto, constitucionalmente inacessível e inviolável, sua

\footnotetext{
${ }^{247}$ Heitor Lyra. História de Dom Pedro II. Volume II: Fastígio (1870-1880). Op. cit., p. 30 e p. 32.
} 
personalidade ainda mais se impunha ao país pelas excelsas qualidades morais de sua pessoa. Entendia ser, e era realmente, o Monarca. A serenidade, que sabia guardar diante de qualquer ataque mais brusco, que pretendesse atingi-lo, longe de o diminuir ou o depreciar no conceito de seus concidadãos, ainda mais o elevava e impunha. ${ }^{248}$

Após tratar da consolidação de d. Pedro II no campo político, Lyra parte para o tema obrigatório de qualquer biografia do imperador, assunto que está diretamente ligado à política: a cultura do monarca. Segundo o autor, ele, definitivamente, "não era um sábio". Sua ciência, e seria essa a maneira correta de tratar do assunto, mais do que profunda, "abrangia uma larga superfície". Interessante notar como Lyra, apesar de admirar o monarca, não se deixa levar por certos temas tão comentados, tal como é o caso de o imperador ser ou não um sábio; daí porque afirma, mudando um pouco o foco da questão, que, "se ele não chegou a ser um sábio, tão pouco se limitou a ser apenas um homem instruído. Foi mais do que isso: foi um verdadeiro erudito". Essa caracterização do monarca, se não deixa de ser positiva, revela uma forma distinta de abordar o tema; não há nenhum rasgo de admiração, nenhum exagero ou apologia. Há como que uma constatação do fato; assim, não há problema algum em dizer que d. Pedro não era um sábio genuíno, mas "possuía aquela sede insaciável de saber, aquele interesse, jamais diminuído, por tudo quanto se relacionava com as coisas da inteligência". O que lhe faltava, em suma, era a verve do verdadeiro humanista. Em contrapartida, sobrava-lhe a do pedagogo. De acordo com Lyra, "essa predileção pela cátedra ele a manifestara toda a vida”, o que se confirmava no seu tão comentado desejo de, ao invés de imperador, querer ser mestre-escola; mais do que isso, seu maior interesse "não foi outro senão o de ensinar aos homens públicos do Brasil a governarem um país de regime constitucional representativo"; o imperador, quase uma obsessão, queria ensinar o que era uma verdadeira democracia, "somente ele esquecia que faltava

\footnotetext{
${ }^{248}$ Heitor Lyra. História de Dom Pedro II. Volume II: Fastígio (1870-1880). Op. cit., p. 120. "Sua intervenção se exercia tanto nos mais altos como nos mais insignificantes detalhes da administração pública. Junto aos Ministros, essa vigilância era então sem limites. Não os deixava sossegados. Com cartas, com bilhetes - além das interpelações verbais - com lembretes, com arrazoados (que ele chamava reflexões, sempre preocupado em não chocar nenhuma susceptibilidade mais aguda, em não parecer que estava querendo impor sua opinião) o Imperador não dava uma folga naquilo que entendia ser, por excelência, o cumprimento de seu dever de chefe de Estado. Nisto era infatigável, quase tirânico. Mais tarde se dirá que ele só exercera uma tirania: a da moralidade", pp. 162-163. Outro exemplo de sua ação junto aos políticos: "De fato o Imperador era de uma intransigência irredutível sempre que se tratava de isolar a política ou a administração pública de todo o interesse que não fosse propriamente o do país. Nisto o seu espírito de moralidade era insuperável. Pode nem sempre ter evitado que políticos menos escrupulosos, mesmo dos mais acatados, ou funcionários prevaricadores, fugissem a uma justa punição. Mas, em regra, sempre que um fato menos justificável the vinha ao conhecimento, ele não deixava de punir o responsável com os recursos que lhe dava a lei", pp. 430-431.
} 
ao Brasil o principal requisito, que era, afinal, a própria democracia". Neste momento, Lyra comenta que são muito coerentes aqueles que afirmavam e afirmam que d. Pedro "levou cinquenta anos a fingir que governava um povo livre". No entanto, faz apenas uma pequena ressalva, o que torna as coisas mais claras: "seria talvez mais exato dizer, em vez de um povo livre, um povo culto, porque a liberdade não pode existir onde não há cultura. E o Brasil de então não era, como não é ainda hoje e não será tão cedo, um povo culto". ${ }^{249}$ Seguindo a tônica de toda a obra, d. Pedro II nunca é tomado enquanto elemento isolado; assim, suas fracassadas pretensões de cultura, se não encontravam ressonância, era devido à pobreza do ambiente. Isso não significa que algumas atitudes do monarca não guardassem certo exagero. Essa é uma característica marcante do texto de Heitor Lyra: quando surge um dilema interpretativo, há sempre um equilíbrio nas apreciações acerca do monarca; o fundamental é entendê-lo como o consolidador dos alicerces nacionais, mesmo que tenha havido equívocos pelo caminho. $\mathrm{O}$ tema da sapiência, assim, apesar de central, não aparece enquanto tal para o leitor; o autor, de maneira habilidosa, reconhece os riscos que aí estão envolvidos e dribla as críticas que sobre isso podem ser feitas. Note-se, por exemplo, que, ao comentar as poesias de d. Pedro II e a sua possível falsa autoria, Heitor Lyra é categórico. Sobre esse assunto que alguns autores fizeram carro chefe de suas interpretações - ele simplesmente puxa uma breve nota de rodapé para dizer que, primeiro, não pode emitir opinião acerca da autoria por falta de provas; segundo, "sem embargo, concorda com que há, de fato, uma grande diversidade de técnica, de sentimento e de maneira entre várias dessas produções". ${ }^{250} \mathrm{O}$ autor, assim, dá mostras de sagacidade, pois sabe que está inserido em um debate; ao reconhecer os riscos da transcendência garantida pela sabedoria, elabora uma concepção positivada, mas não definitiva, o que lhe permite, de certa forma, englobar algumas opiniões contrárias.

No final do volume sobre o fastígio, um tema é abordado de forma mais demorada; trata-se da aprovação da lei Saraiva. É interessante notar como Heitor Lyra, que dedica bom número de páginas ao assunto - ressalte-se, desde já, uma coisa interessante: em nenhum momento, Lyra toca na questão do senso literário, o que tornava a lei Saraiva, ao mesmo tempo, tão progressista e excludente -, dá destaque à ação do imperador que, mesmo ressabiado, contribui muito para a aprovação da reforma

\footnotetext{
${ }^{249}$ Heitor Lyra. História de Dom Pedro II. Volume II: Fastígio (1870-1880). Op. cit., pp. 172-174.

${ }^{250}$ Heitor Lyra. História de Dom Pedro II. Volume II: Fastígio (1870-1880). Op. cit., p. 183.
} 
eleitoral. Um motivo da desconfiança: o monarca acreditava que qualquer mudança política consistente só se daria pela educação do povo, e não por uma reforma na legislação. De acordo com o autor, as primeiras eleições seguintes à reforma, confirmando a opinião do monarca, deixaram clara a ineficiência da reforma e evidenciavam as fraudes da politicagem. A lei não funcionara plenamente, não por culpa dela, mas

por culpa dos homens, votantes e votados, por culpa dos chefes, grandes, médios, pequenos; por culpa também dos partidos, mal constituídos, desarticulados, inorgânicos, inexpressíveis - numa palavra, por culpa da escassa cultura política do país. [...] Os vícios, portanto, as deficiências do sistema eleitoral vigente, não resultavam de leis nem de processos de eleição incompletos ou inadequados; eram, como muito bem dizia Joaquim Nabuco, uma questão de moral social, política e privada. É que, infelizmente, faltava aos nossos homens públicos essa probidade cívica, tão necessária na vida das nações quanto a probidade moral na vida do homem livre. ${ }^{251}$

O imperador, a partir de sua posição privilegiada, tentava combater essa situação, tentava estabelecer e praticar "uma obra verdadeiramente saneadora e nacional". De acordo com Lyra, a volumosa correspondência trocada entre d. Pedro II e os Ministros, revela essa luta por eleições que fossem efetivas, que pudessem se dar sem “falhas, fraudes, compressões, falsificações, etc.”. E essa dedicação pela "realidade das eleições", uma questão ligada à moralidade do regime, "foi um dos traços principais do Imperador, visto como chefe de Estado, e que o separara distintamente dos políticos do seu tempo". Assim, mais do que nunca, d. Pedro surgia imbuído de seu "papel de civilizador", tendo de agir contra a corrente, "no centro da escassa cultura que era então o Brasil". 252

Outra tarefa que o monarca exerceu dentro de seu papel civilizador: a rotatividade dos partidos políticos. Elemento moral e regulador, ele era um "freio que a paixão partidária não cegava nunca"; era quem continha "os partidos nos seus limites objetivos, quer dizer, naqueles que honestamente lhes era lícito aspirar, dentro de um exato regime representativo". Era ele, portanto, que estava no centro de todo o esquema político-partidário; daí porque Lyra se sente à vontade para dizer que o sistema brasileiro, o regime parlamentar vigente no Segundo Reinado, era uma farsa. Nesse sentido, afirmar, novamente, que o imperador levou cinquenta anos fingindo que governava um país de homens livres era "a maior verdade política que já se disse do

\footnotetext{
${ }^{251}$ Heitor Lyra. História de Dom Pedro II. Volume II: Fastígio (1870-1880). Op. cit., pp. 484-485.

${ }^{252}$ Heitor Lyra. História de Dom Pedro II. Volume II: Fastígio (1870-1880). Op. cit., pp. 490- 492.
} 
regime constitucional representativo do Império". Acima dos partidos liberal e conservador, o que havia, de fato, "era uma partido do governo e um partido de oposição, não no sentido clássico do parlamentarismo inglês, mas no sentido puramente de política partidária". O ponto de referência de todo o regime, então, era o imperador, que tinha de lidar com "o que se chamava entre nós a "fome do poder". Ao utilizar-se do poder moderador e exercer o cargo de chefe do executivo, d. Pedro II era uma espécie de - em uma combinação exemplar de transcendência e imanência - "Deus ex machina do regime, o homem que faz e desfaz, que manda e desmanda". Assim, aquilo que podiam acusar como sendo poder pessoal "não era, portanto, produto da vontade ou da ambição de mando do Imperador, mas da própria organização constitucional do país, e da falta de cultura política do povo". Não era por interesse pessoal que se intrometia "arbitrariamente na economia dos partidos, elevando-os e apeando-os do poder ao seu inteiro talante, criando situações políticas e pactuando, até certo ponto, com os Gabinetes, na formação de maiorias parlamentares". Era, antes de tudo, uma necessidade do tempo, uma obrigação a ser cumprida diante da fraqueza política do país. De acordo com Lyra, em um comentário que soa quase estranho, "esse seu procedimento era sem dúvida absolutista, e falseava, até certo ponto, o verdadeiro sistema representativo". Em outras palavras, posto que a intervenção do monarca era de vital importância para a manutenção da ordem, um político eleito pelo sufrágio popular, "único mandatário direto da soberania popular, não gozava da independência a que tinha direito". ${ }^{253}$ Feitas no fim do segundo volume, essas colocações, mesmo que não sendo negativas ao imperador - pelo contrário, acabam por reafirmar a sua importância para o regime -, revelam um desgaste, dão a entender que o período de fastígio atingia seu limite. Como ressaltado, uma das características mais marcantes dessa biografia é a sinceridade no trato com temas espinhosos; no entanto, é nítido que, a partir da reforma eleitoral, estava em risco a própria dinâmica do regime. Ficava perceptível a necessária parcela de farsa do sistema, assim como o necessário absolutismo do monarca. De certa forma, estava em risco a legitimidade do regime; é, portanto, o início do declínio.

No terceiro volume, o primeiro grande tema a ser abordado é o abolicionismo. Foi com a campanha abolicionista que se sentiram, com mais vigor, "os primeiros sintomas de declínio do Império". A partir dela ficava claro que "as instituições

\footnotetext{
${ }^{253}$ Heitor Lyra. História de Dom Pedro II. Volume II: Fastígio (1870-1880). Op. cit., p. 507, p. 510, p. 513, p. 521 e pp. 524-525.
} 
monárquicas no Brasil já tinham dado o que deviam ou podiam dar”; tinham cumprido "sua principal finalidade histórica, que fora preservar e transmitir às gerações vindouras a unidade de raça e do país, tão duramente abaladas nos anos difíceis da adolescência". As tradições imperiais chegavam ao limite, a fé monárquica "começava francamente a desaparecer". ${ }^{254}$ Acerca das manifestações pela libertação dos escravos, de acordo com Lyra, d. Pedro II manteve - e aqui se revela toda a produtividade do arranjo - "uma atitude de simples espectador”. A simpatia que demonstrava pela causa da emancipação se limitava ao âmbito puramente pessoal; "porém, como chefe de Estado, nada há de que se lhe possa atribuir. Toda a sua ação até então, e mesmo até o fim da campanha, foi muito mais reservada, muito mais discreta, do que durante o período de elaboração da lei do Ventre-livre". O seu discreto posicionamento teria durado até o momento em que a causa adquiriu "proporções de uma verdadeira campanha nacional, cívica e social, transformando-se no que Graça Aranha chamaria mais tarde a loucura da abolição". Nesse contexto, era preciso agir, marcar uma posição; mesmo não se engajando diretamente ao lado dos abolicionistas, tinha de "assumir ao menos uma atitude claramente definida, atitude de equilíbrio, equidistante entre a perronice dos escravocratas e o radicalismo dos extremistas" ${ }^{, 255}$. Assim, com sua constante postura equilibrada e justa, era o farol necessário para não afundar o país em uma disputa de interesses opostos; era aquele que podia, ao contrário dos demais envolvidos, proporcionar o melhor desenlace para o interesse nacional. $\mathrm{O}$ grande mérito do imperador fora justamente essa abnegação, o equilíbrio de entendimento, não se deixar "vencer totalmente pelo medo ou pela inércia dos estadistas". Somente por causa dele, por sua atuação corajosa e apartidária, evitou-se

uma luta armada talvez mais terrível, e certamente de muito piores consequências para nós do que fora para os Estados Unidos a guerra de Secessão. O serviço que nos prestou o Imperador foi, portanto, o de acordar a consciência entorpecida dos políticos, e de servir-se dela para obrigar o Parlamento a enfrentar corajosamente o problema. 1871, 1885, 1888, para não citar também a primeira delas, 1850 , são datas que ficarão na história do Império a bem dizer traçadas pela mão de Dom Pedro II. ${ }^{256}$

A campanha abolicionista, se, por um lado, revelava o limite das instituições monárquicas no Brasil, por outro, coincidiu com a crise da saúde do imperador. Nesse ponto, Heitor Lyra comenta como a própria aparência do imperador não fazia mais jus

\footnotetext{
${ }^{254}$ Heitor Lyra. História de Dom Pedro II. Volume III: Declínio (1880-1891). Op. cit., pp. 59-60.

${ }^{255}$ Heitor Lyra. História de Dom Pedro II. Volume III: Declínio (1880-1891). O. cit., p. 14.

${ }^{256}$ Heitor Lyra. História de Dom Pedro II. Volume III: Declínio (1880-1891). Op. cit., p. 56.
} 
ao que se deveria esperar de "um Imperador, no sentido histórico da palavra". Era uma crise, portanto, que se manifestava nas instituições políticas e, também, em aspectos físicos e materiais, pois nada era mais anti-imperial "do que aquele ancião de gestos brandos e lento caminhar, de aspecto pesado, sempre vestido de preto, com a sua indefectível casaca"; que passeava pelas ruas de Petrópolis, "sempre polido, sempre cortês para com todos, muito simples e natural, mesmo um pouco acanhado, parecendo até vexado com a cerimoniosa atitude que lhe dispensavam os passantes". Assim, o homem, com sua saúde frágil e conduta aburguesada, estava um tanto desajustado de sua função, começava a falhar o seu feitiço; como diz Lyra, d. Pedro II estava como que em um "divórcio do mundo objetivo", vivia um retraimento que "concorria não pouco para fortalecer no espírito público a crença, que se formara, de ser o Imperador um homem de sentimentos inexpressíveis, insensível às vibrações do mundo exterior". ${ }^{257} \mathrm{~A}$ natureza era severa com o imperador; perdia, quando mais era necessária, a energia demonstrada em outras épocas; "sentia-se que lhe faltava aquele vigor moral dos bons tempos da questão Christie e da guerra do Paraguai”. Não se impunha mais diante das controvérsias entre partidos e políticos; não conseguia cumprir com sua função de coordenador de disputas; deixara de ser o ponto de equilíbrio de todo o regime. $\mathrm{O}$ nó do arranjo começava a perder firmeza, seu aspecto apolítico se sobrepunha ao político; dessa forma, vinha à tona a piada e a caricatura. Com o crescimento do movimento republicano, "para muitos, ele não passava agora do velho, como se dizia, quase uma sombra de si mesmo; era o Pedro banana, na expressão irreverente do povo, sempre impiedoso na apreciação daqueles que a fortuna abandona, mesmo transitoriamente". ${ }^{258}$

Por fim, Heitor Lyra se propõe uma questão, para a qual, a partir de uma concepção peculiar de história, formula explicações curiosas, que não implicam condenações dos personagens, mas que não são, seguindo a lógica de toda a obra, completamente isentas de críticas. A citação é um pouco longa, mas vale a pena ser feita:

Como se explica que um Império de quase setenta anos de existência, e um Monarca cujo reinado, se não fora uma época de grande brilhantismo, de lances heroicos, de fausto e de largas farturas, fora, contudo, meio século de esforços em prol do progresso material e moral da nação, do bem estar e sossego de todos, tivessem desaparecido da noite para o dia, diante da simples ameaça de alguns batalhões, reunidos numa praça pública, em atitude quase de parada? Uma pedrada, dizia Voltaire, um pouco

\footnotetext{
${ }^{257}$ Heitor Lyra. História de Dom Pedro II. Volume III: Declínio (1880-1891). Op. cit., pp. 83-84.

${ }^{258}$ Heitor Lyra. História de Dom Pedro II. Volume III: Declínio (1880-1891). Op. cit., p. 152.
} 
mais forte do que aquela que recebeu Mahomet [sic] no seu primeiro combate, daria um outro destino ao mundo. Os grandes acontecimentos históricos são na maioria das vezes produtos de pequenos incidentes, e a mola que os faz deflagrar não é senão um detalhe. O ambiente que os forma é que é tudo. A psicologia das revoluções está em que elas contam menos pelo que fazem os seus promotores, do que pelo que deixam de fazer os seus adversários. Deixem amadurecer os acontecimentos, dizia Montesquieu, e eis as revoluções! Sem referir a fatores já sobejamente conhecidos, diremos que nada concorreu tanto para preparar os acontecimentos que nos levaram à República do que o espírito frondeur, mais que isso, demolidor das instituições, que ostentaram sempre os próprios estadistas da Monarquia. Isto por um lado. Por outro lado, não concorreu menos a displicência do Imperador, o seu indiferentismo quase budista pela sorte do regime. E, finalmente, se bem que em menor escala, a propaganda republicana. ${ }^{259}$

A explicação da crise do Império está na combinação do detalhe e do acaso com o contexto. Assim, mesmo que o monarca tenha sido condizente com a crise do Império, ela não foi culpa sua. O regime estava desgastado, o que fazia com que qualquer pequena indignação, qualquer propaganda republicana, ganhasse ares de revolução. $\mathrm{O}$ monarca, displicente que foi, não se exime de responsabilidades; no entanto, não pode ser julgado como o grande agente da crise. Ao elaborar essa imagem, a de que a queda do Império pode ser entendida como consequência de "pequenos incidentes", Heitor Lyra está consolidando d. Pedro II como grande governante. Independente de regimes políticos, interesses partidários e disputas pelo poder, quem restava, pairando acima de todos, era o imperador, um dos "grandes consolidadores dos alicerces da nossa nacionalidade", responsável por manter a ordem presente e possibilitar, às gerações futuras, uma nação bem estruturada. Afinal, d. Pedro II herdara pouco e legara muito. Nesse raciocínio, se as revoluções são consequências de pequenos incidentes feitos grandes pelo ambiente que os cerca, detalhes potencializados ao acaso, o regime de $\mathrm{d}$. Pedro II não era nada disso, por isso resta nas páginas mais gloriosas da história nacional. Não era um acaso, mas uma realidade bastante sólida. D. Pedro II, durante os dois últimos anos de sua vida, dando uma prova da grandeza moral de seu espírito de patriota, "não manifestava a menor sombra de despeito ou de rancor. A possibilidade de rever a pátria seria quase uma ideia fixa nele. Voltaria - mas se o chamassem, era a condição que impunha. Não tentaria jamais obrigar ninguém a aceitá-la”. Desejava o melhor para seu país e para o novo governo; “de conspirações para o restabelecimento da Monarquia e de sua família no trono, nem queria ouvir falar”. Essa postura, apesar de todas as amarguras e percalços do exílio, jamais a abandonou; "não se lhe mudara o

\footnotetext{
${ }^{259}$ Heitor Lyra. História de Dom Pedro II. Volume III: Declínio (1880-1891). Op. cit., pp. 227-229.
} 
caráter; guardava ainda aquela altiva nobreza que o caracterizava, e que não era senão o reflexo da probidade de seu espírito. Jamais se lhe ouvia uma queixa; jamais uma crítica severa" ${ }^{260}$ Nessa interessante obra, feita por um viés conservador, dedicada ao pai, político do Império e da República, pensada na dinâmica entre indivíduo e contexto, pesquisada em documentos franqueados pelo neto do biografado, esse é o exemplo feito objeto da memória: um governante que, patriota e disposto a consolidar seu país, coloca-se acima de disputas fúteis e interesseiras; em alguns momentos, até por demais. Trata-se, então, de um vulto insigne, merecedor desse monumento, bastante sincero, feito de palavras.

${ }^{260}$ Heitor Lyra. História de Dom Pedro II. Volume III: Declínio (1880-1891). Op. cit., p. 281 e p. 298. 


\section{2. FLORES COM ESPINHOS}

\section{2. 1. Vicente Licínio Cardoso: as bases precárias}

"A história exige, para ser honesta e verdadeira, o fundamento de condições estruturais econômicas. A vida dos povos é uma vida de necessidades orgânicas, anônimas e inconscientes muitas vezes, as que, por isso mesmo, exigem dos historiadores robustos o esforço de uma exumação clarividente. [...] O problema último do historiador é em verdade dar, na tessitura do relato, consciência social aos acontecimentos inconsciente e organicamente evoluídos".

Vicente Licínio Cardoso, em

"À margem do Segundo Reinado".

Conforme já comentado, completo o primeiro quartel do século $\mathrm{XX}$, era tempo de um novo e espinhoso momento para o regime republicano: o centenário de nascimento do imperador, a ser celebrado em dezembro de 1925. As comemorações não foram tranquilas e instigaram importantes debates, encarniçando desilusões e críticas de republicanos recalcitrantes; até mesmo improváveis reverberações monarquistas espocaram na ocasião. Provas dessa tensão memorialística podem ser encontradas em algumas das obras escritas por causa da efeméride. Homenagens laudatórias, como a de Magalhães de Azeredo, por certo, foram realizadas; alguns dos principais intelectuais da época, contudo, quando se debruçaram sobre o tema, ao invés de apologias e saudações personalistas, realizaram interpretações amplas do Segundo Reinado - um evidente intento de buscar, no passado nacional, alguns dos alicerces nos quais se baseou a formação do regime republicano. Essa investigação do passado para encontrar respostas aplicáveis ao presente é sintomática do modelo intelectual de então; até cerca de 1930, quando não se havia estabelecido ainda a pesquisa das ciências sociais em instituições de ensino superior, os estudos de História e Sociologia eram carregados de proposições e interesses de intervenção social. Tratava-se de um pensamento engajado ou, conforme a caracterização de Nilo Odália, um pensamento fundante. ${ }^{261}$ Exemplos dessa postura,

\footnotetext{
261 "No caso da historiografia brasileira, do século XIX até mais ou menos os anos 30 deste século [XX], a corrente predominante, majoritariamente predominante, foi a que se caracterizou por seu caráter fundante e/ou engajado. Que tenha sido assim, é mais do que compreensível, pois não podemos esquecer que o Brasil se transformou, de um dia para o outro, de colônia em país independente". Nilo Odália. $A s$ formas do mesmo. São Paulo: Ed. UNESP. 1997, p. 122.
} 
no que diz respeito ao centenário de d. Pedro II, estão nos estudos de Capistrano de Abreu e Oliveira Vianna, feitos em 1925, além do balanço da monarquia brasileira, realizado por Oliveira Lima no ano de 1927.

Um dos mais intrigantes trabalhos sobre o assunto, entretanto, é obra de um autor pouco comentado, pelo menos nos dias de hoje: $\grave{A}$ margem do Segundo Reinado, de Vicente Licínio Cardoso. Este intelectual, nascido no Rio de Janeiro, em 1890, reveste-se de certa obscuridade por conta da escassez de informações biográficas. Sergio Miceli, em seu breve livro a respeito da Primeira República, dá notícia de que Licínio Cardoso era engenheiro, professor da Escola Politécnica e da Escola Militar, "filósofo e autor de diversos ensaios sobre a sociedade brasileira". ${ }^{262}$ A principal vertente teórica adotada pelo autor foi o positivismo - mesmo que algo ressabiado em certos momentos -, o que se faz sentir nas suas obras e nos diversos textos que publicou pela imprensa, dentre os quais, além de análises políticas e históricas, despontam estudos literários e biográficos. Na vida do autor contam fatos curiosos, alguns flertando com o quixotesco, tal como a expedição que realizou por todo o curso do rio São Francisco, a fim de relacionar as potencialidades de seus recursos hídricos, e o envolvimento, um traço de distinção amadora e apego à modernidade, com a fundação do Botafogo Football Club - atual Botafogo de Futebol e Regatas. O fim de tão peculiar figura foi trágico: suicidou-se no ano de 1931, o que dá traços ainda mais nebulosos à sua biografia. O certo mesmo é que Licínio Cardoso é o típico intelectual da virada do século XIX para o XX; inspirado ainda pelo pensamento cientificista e pela noção de progresso, atua em um campo não específico, no qual cultura e política, teoria e prática, discurso e ação, todos dialogam muito próximos. Inegável, também, é a importância desse autor no cenário intelectual da Primeira República. Em seu O império brasileiro, Oliveira Lima toma Licínio Cardoso como "um representante da nova geração intelectual da República" e, mais ainda, "um dos espíritos mais argutos" de sua época. Em 1922 - mais um esforço interpretativo e memorialístico surgido no contexto do centenário -, ele foi o responsável por coordenar um renomado grupo de intelectuais Gilberto Amado, Pontes de Miranda, Antônio Carneiro Leão, Tristão de Ataíde, Ronald de Carvalho e Oliveira Vianna - que, tendo vivido as primeiras décadas da República, se reuniu para realizar um balanço do novo regime. O resultado foi a obra coletiva $\grave{A}$ margem da história da República, da qual, apesar da rica diversidade de temas e

\footnotetext{
${ }^{262}$ Sergio Miceli. Poder, sexo e letras na República Velha. São Paulo: Perspectiva, 1977, p. 77.
} 
posicionamentos dos autores, emergia uma opinião inequívoca: o regime implantado em 1889 havia falhado em muitas de suas propostas e precisava buscar novas alternativas. $\mathrm{Na}$ conclusão do volume, o organizador dava o veredito: "foi profunda a nossa desilusão, por certo. [...] Vemos a cada momento, em torno de nós, a negação - não só de tudo o que sonhamos, também de tudo o que pensamos". ${ }^{263}$

Imbuído deste espírito inquieto, dois anos depois e parafraseando o título da obra anterior, nosso autor fez sua leitura do Segundo Reinado. Apesar do tom pessimista, Vicente Licínio nega qualquer remorso ao falar da proclamação da República, porque, um dado fundamental, é uma lógica progressista a que caracteriza o seu pensamento; logo, a história tem de avançar no compasso das mudanças. Por conta disso, parte para a crítica da historiografia: ressalta, a princípio, que a maioria das interpretações acerca do reinado de d. Pedro II, feitas até então, muito ajustadas que estavam "à nossa imaginação tropicalista" (expressão que, curiosamente, lembra aquela usada por Magalhães de Azeredo), tinham-se focado em aspectos políticos, deixando de lado aquilo que efetivamente dizia respeito às "realidades brasileiras". Uma figura do calibre de Joaquim Nabuco, por exemplo, um dos que fomentou o amargo arrependimento, teria sido um analista distraído, posto que focado nas vias oficiais de manifestação política, se esquecendo da força que assumia o republicanismo na vida política

\footnotetext{
${ }^{263}$ Apud: José Murilo de Carvalho. "Introdução". In: Oliveira Vianna. O ocaso do Império. Rio de Janeiro: Academia Brasileira de Letras, 2006, p. X. Gilberto Freyre, em Ordem e progresso, faz os seguintes comentários acerca de tal obra coletiva, o que dá boa noção de seu teor: "Uma das expressões daquela inquietação dos jovens, mais marcada pelo espírito da crítica e pelo desejo de renovação, se não de revolução, se refletiria nos depoimentos de intelectuais brasileiros nascidos no Império ou nos primeiros anos da República, e crescidos com a República e na República: depoimentos reunidos no livro À margem da história da República (Rio, 1922). Um dos colaboradores, o professor Pontes de Miranda, escrevia aí contra o estadualismo reinante: 'o Estado que se acha no poder, qualquer que seja ele [...] feitoriza o Brasil como o escravocrata feitorizava a fazenda'. E acrescenta que, contra semelhante estadualismo, só a 'reação agregante' que, 'sem desatender a legítimos interesses locais', considerasse principalmente a 'unidade nacional'. Outro, Ronald de Carvalho, assim se exprimia: 'Deixemos de pensar em europeu. Pensemos em americano. Temos o prejuízo das fórmulas, dos postulados e das regras que não se adaptam ao nosso temperamento'. Vicente Licínio Cardoso veria os políticos republicanos - os dominantes - preocupados só com 'problemas secundários', 'questões partidárias', 'regionalismos deletérios' e 'comentários constitucionais esdrúxulos ou fetichistas', e esquecidos dos problemas importantes de saneamento, comunicação, educação, higiene. Oliveira Viana [sic.] pregaria a necessidade, para o Brasil, de uma legislação, de uma 'arquitetura política', de um novo 'sistema político', em que o legislador, o reformador, o reorganizador, 'antes de se mostrar um homem de seu tempo', se mostrasse 'de sua raça e de seu meio'. Poderia talvez ser acrescentado: do seu passado. E o professor Gilberto Amado insistiria em tese já antiga, por ele defendida com uma nitidez latina de pensamento e de palavra desde 1915: a necessidade de se considerarem os problemas brasileiros de administração e de governo em relação com o meio social. Com os antecedentes sociais peculiares ao Brasil”. In: Ordem e progresso. Op. cit., pp. 81-82.
} 
brasileira. $^{264}$ Já Euclides da Cunha (1866-1909), uma das principais referências intelectuais de nosso autor, teria ido além: evitando falar somente dos registros do Parlamento, do imperador ou de qualquer outra fonte oficial, Euclides preocupou-se em entender a "formação da ideia republicana" ${ }^{265}$ Partindo desta perspectiva euclidiana, Licínio Cardoso rastreia as "condições estruturais econômicas" sobre as quais erigir o seu ensaio; a partir disso, demonstra como o Segundo Reinado foi marcado por iniciativas político-econômicas ineficazes e pelo não aproveitamento das potencialidades da nação que se constituía.

À margem do Segundo Reinado, dessa maneira, é um entendimento amplo do regime de d. Pedro II, uma proposta analítica de quem, pensando o passado com olhos postos nas questões do presente, não se prende aos aspectos superficiais da história e procura a formação profunda da nação. Só consegue conceber essa interpretação aquele que escapa do centro intelectual e vai à margem do pensamento estabelecido; aquele que parte, imbuído de aparelhagem intelectual adequada, atrás do problema (lembre-se sempre: Euclides da Cunha é o paradigma). Nesse sentido, são questões econômicas que vão pautar todo o texto; sem entender a estrutura da produção, não haveria como apreender o sentido amplo e orgânico da formação nacional. O principal tema que exaspera Licínio Cardoso é a falta de investimentos e diversificação na economia brasileira da segunda metade do século XIX, o que manteve limitada a capacidade agrícola e não impulsionou a indústria nacional. Isso, justamente, no século que foi das inovações, "do carvão, do aço, da máquina. O século da transição econômica mais violenta até hoje operada entre os povos: o destronamento do binário ouro e escravo pelo binário mais enérgico, máquina e carvão". O Brasil, nação de imensas potencialidades, ficou descompassado, não pelo atraso na comunhão com as inovações, mas pela falta de mudanças estruturais em sua economia, pela política centralizadora

\footnotetext{
${ }^{264}$ Lembre-se que Oliveira Vianna também se mostrou, mesmo que por razões diversas, extremamente crítico desse remorso republicano: "Veio a República. Veio a Democracia. Veio a Federação. E para logo se levantou um sussurro de desapontamento do seio da turba fanatizada - e esse desapontamento se acentuou, com o tempo, numa permanente desilusão. Os mais fortemente desiludidos foram precisamente os mais ardentes evangelizadores do novo credo. Os Cristos da Nova Revelação foram justamete os que mais alto fizeram ressoar o refrão do seu desanimo. - Não era esta a República dos meus sonhos! diziam, sucumbidos, amargados de melancolia." Adiante, completa: "Para eles, a causa do fracasso não estava no regime, tal como ele foi ideado na constituição [de 1891]; mas apenas nos homens - ou porque 'inexperientes', ou porque 'corruptos'. [...] Evidentemente, deve haver uma causa mais profunda, que explique tamanha incapacidade e tão longo e continuado insucesso. Esta causa existe e é, como já assinalamos, o desacordo entre o idealismo da Constituição e a realidade nacional". Oliveira Vianna. $O$ idealismo da constituição. São Paulo: Companhia Editora Nacional, 1939, pp. 84-85 e pp. 92-93.

${ }^{265}$ Vicente Licínio Cardoso. "À margem do Segundo Reinado". In: À margem da história do Brasil. São Paulo: Editora Nacional, 1979, (Coleção Brasiliana; v. 13), p. 74.
} 
descontextualizada e pela pobreza em que restou o "pensamento econômico brasileiro, sem ter havido nenhuma compreensão oficial suficientemente enérgica de nossas realidades mais prementes". 266

No que diz respeito à organização econômica, Licínio Cardoso trabalha com a ideia de "realidades brasileiras", o que pode ser entendido, grosso modo, como a estrutura herdada dos tempos coloniais. Nesse sentido, a economia do Brasil monárquico vai permanecer atrelada à produção agrícola, ao trabalho escravo e aos interesses da exportação. As grandes conquistas da independência e da formação do Império teriam sido, nessa lógica de permanência, a manutenção da unidade territorial mesmo com o legado centrífugo do período colonial - e do regime de trabalho escravo; tais fatores, além de preservarem as características coloniais, vão manter o poder centralizado nas mãos da elite proprietária. Diante desse quadro, ficou impossível acontecer aquilo que Licínio Cardoso chama de "democratização pela terra"; sinal político disso, os ímpetos republicanos rebeldes foram, desde cedo, prontamente combatidos, como na revolta pernambucana de 1824. Segundo o autor, somente com a produção cafeeira baseada na mão de obra livre é que iria florescer o ideal republicano no Brasil. Com a vida política enfraquecida e a economia de base agrária mantida, a escravidão, com todos os seus significados econômicos e sociais, passou a ser o principal elemento de equilíbrio do nascente Estado. Mesmo nos momentos em que a centralização ficou mais flexível, como no período regencial, quando vigorava o Ato Adicional (aprovado em 1834), as revoltas que espocaram por todo o país demonstraram claramente para as elites imperiais que a centralização política, jurídica e fiscal era elemento inevitável para a manutenção das estruturas do país, pelo menos se se quisesse isso com a unidade nacional e com o regime de trabalho escravo.

Foi nesse contexto conturbado que o jovem Pedro de Alcântara assumiu o trono, apoiado por uma reação conservadora e por liberais assustados com as aventuras federalizantes do período regencial. De acordo com Licínio Cardoso:

Pedro II conseguiu, pela individualidade de sua pessoa, protegido por condições especiais da evolução brasileira na América, retardar de meio século o advento da República, protelar, em suma, aquilo que a Regência experimentara antes com perigo, por isso que fora prematura, mas sem desfalecimentos de energia. ${ }^{267}$

\footnotetext{
${ }^{266}$ Vicente Licínio Cardoso. “À margem do Segundo Reinado”. Op. cit, pp. 90 e 91.

${ }^{267}$ Vicente Lícinio Cardoso. "À margem do Segundo Reinado". Op. cit, p. 123.
} 
Uma das consequências dessa política de protelação foi que o país independente, ao se consolidar em Estado nacional, não rompeu plenamente com seu passado de exploração exógena, não conseguiu mudar substancialmente sua inserção no quadro da economia mundial, mesmo acabando com o tráfico de cativos, aprovando leis comerciais e colocando em pauta a imigração. Sobre esta última, por exemplo, comenta o autor, demonstrando a pouca efetividade de planos que não foram acompanhados por investimentos em infraestrutura e pela mudança com relação ao regime de trabalho:

os projetos de colonização eram oficiais: ficaram oficiais, teóricos, artificiais. A opinião pública pouco cuidou, excetuando São Paulo [...]. Há histórias da colonização: são histórias administrativas apenas. Não houve a realidade esplêndida de uma colonização intensa em pleno Império. ${ }^{268}$

A partir de 1860, uma série de medidas legais previa a estabilização do câmbio e a exclusividade em emitir moedas ao Banco do Brasil, que só o faria respaldado nas reservas de metal; porém, estas medidas não foram capazes de apagar as consequências das especulações bolsistas dos anos anteriores e nem de saldar dívidas de investidores particulares. Nesse cenário, uma crise na produção cafeeira na primeira metade da década culminou na quebra de importantes casas bancárias, dentre elas uma das mais respeitadas da praça, a Casa Souto. Esta situação escancarava as bases precárias de uma economia sem alicerces sólidos, que se pautava ainda na lavoura monocultora e voltada para exportações; a falta de diversidade econômica e de mercado interno era mais do que evidente, não criando canais de desafogo. A constatação mais óbvia, conforme argumenta Licínio Cardoso, é que "a economia brasileira só tinha uma fonte, e essa fonte era a lavoura. Qualquer crise dela se propagava a todas as partes e se distribuía a todos os escalões do edifício social, político e econômico". Para o autor, portanto, a crise bancária era somente um reflexo, um "reverbero violento" da verdadeira, "profunda, surda, tormentosa" crise agrícola; o fenômeno vinha de longe, da "deslocação abrupta" de capitais com o fim do tráfico negreiro, o que inaugurou o tempo da "jogatina dos negócios" e a "febre pletórica de companhias que avassalou o Rio". Daí, a constatação:

Isso era a realidade. Certo, não a vislumbraram os políticos do tempo. Olhos fixos na Europa, imitavam com pompa fofa o parlamentarismo inglês, e nenhum deles via o incêndio que ia sobre a riqueza do país, a única riqueza nacional do tempo: a agricultura. ${ }^{269}$

\footnotetext{
${ }^{268}$ Vicente Licínio Cardoso. “À margem do Segundo Reinado”. Op. cit, p. 88.

${ }^{269}$ Vicente Licínio Cardoso. “À margem do Segundo Reinado". Op. cit, pp. 78 a 80.
} 
Para piorar, ao mesmo tempo em que a economia nacional chafurdava em crise, o comércio e as casas bancárias eram majoritariamente dominados por estrangeiros, o que não mantinha parte substancial dos lucros no país. Nesse sentido, a proibição do tráfico negreiro - feita sob a influência da Inglaterra, que buscava novos meios de entrar com seus capitais na economia nacional - fora, segundo Licínio Cardoso, uma luta contra o "capitalismo português", pois eram dessa nacionalidade os maiores importadores de escravos. Diante dessa disputa, os agricultores brasileiros ficaram desprotegidos, continuando a colher a safra dos cafezais, mas sem "nenhuma dilatação de cultivo de novas terras". A produção agrícola, estruturada sobre o trabalho escravo e a grande propriedade, era o sustentáculo da economia nacional, determinando as taxas de câmbio e a circulação de riquezas; porém, a grande lavoura era, também, um repressor que impunha à economia brasileira os seus limites. A crise de 1864 , no dizer de nosso autor, não foi uma crise comercial, e sim uma consequência da desorganização da produção agrícola, da debilidade estrutural da economia brasileira; por conta disso, deveria ter sido "um aviso e um índice". "Não o foi. A lição posterior de 1888 haveria de ser, como foi, por isso mesmo, bem mais séria". 270

Diante do abalo econômico, o comércio, já bastante restrito, ficou paralisado; tal estagnação rapidamente se fez sentir na própria produção agrícola. $\mathrm{O}$ governo teve de agir sem esperar pelo legislativo; esperar pelas resoluções dos congressistas, pelas tais "fofas pompas" - chama atenção a forma como o autor se aproxima, nesse ponto, de Oliveira Vianna, quase reverberando a noção de idealismo utópico ${ }^{271}$-, significaria perda de tempo em face de um cenário caótico. Tomaram-se medidas especiais para as falências e liquidações da bolsa, algumas em favor de banqueiros, outras dos endividados; além disso, vigorou a prática de desvalorização cambial, principal medida do governo para manter os rendimentos com a exportação do café. A Guerra do Paraguai, que começaria logo após o período mais dramático da crise, continuaria a expor as deficiências da economia brasileira. Para bancar o esforço bélico, o governo imperial realizou, às vésperas do conflito, um empréstimo de 7 milhões de libras, cujas condições apelativas deixavam clara a situação de precariedade das finanças

\footnotetext{
${ }^{270}$ Vicente Licínio Cardoso. “À margem do Segundo Reinado”. Op. cit, p. 80.

271 "Idealismo utópico é, para nós, todo e qualquer sistema doutrinário, todo e qualquer conjunto de aspirações políticas em íntimo desacordo com as condições reais e orgânicas da sociedade que pretende reger e dirigir. $\mathrm{O}$ que realmente caracteriza e denuncia a presença do idealismo utópico num sistema constitucional é a disparidade que há entre a grandeza e a impressionante euritmia da sua estrutura e a insignificância do seu rendimento efetivo - e isto quando não se verifica a sua esterilidade completa." Oliveira Vianna. O idealismo da Constituição. Op. cit, pp. 10-11.
} 
nacionais. ${ }^{272}$ Com o início dos combates, os gastos públicos subiram a níveis altíssimos, resultando no aumento de impostos e na necessidade, a fim de não travar as finanças, de voltar a emitir moeda. Licínio Cardoso acusa certa irresponsabilidade do gabinete liberal, então no poder, em lançar o Brasil no conflito; mas, por outro lado, ressalta que a guerra foi, contraditoriamente, uma válvula de escape da economia e da política nacionais:

sedentos de glória e de renome, temerosos quanto à situação interna, calamitosa mais tarde (mesmo em 1864) refletida através da crise violentíssima da capital do Império, aproveitando o incêndio do patriotismo popular em consequência da questão inglesa (em 1864) [trata-se da questão Cristhie], lançaram os liberais na aventura de uma guerra externa. ${ }^{273}$

Enquanto ao menos 50 mil soldados brasileiros morriam nos campos de batalha, a derrubada do gabinete liberal para a elevação dos conservadores ao poder lançou a figura do imperador sob grave suspeita, o que significava colocar em dúvida a própria estrutura de poder do regime monárquico. De acordo com Vicente Licínio Cardoso, o evento bélico, decorrência das relações externas brasileiras, acabou se transformando no "divisor de águas especialíssimo" da política interna. A guerra, assim, acrescentou novos fatores à vida nacional, funcionou tal como um dínamo ideológico, separou

a agitação monárquica, fermentada dentro dos partidos - de acanhada significação política, aliás - da evolução democrática republicana firmemente esboçada desde 1870. Passa-se, em verdade, da figura isolada de Teófilo Otoni, agitador destimerato de 1862, às reações de 1869 e 1870, em que os manifestos dos liberais e dos republicanos indicam, de fato, um começo de unidade de vistas, uma agremiação de ideias, um programa em suma. $^{274}$

Os militares teriam encontrado no cenário político brasileiro um espaço propício para dar vazão aos seus ideais salvacionistas, afinal, no juízo de Licínio Cardoso: "seja como for, a guerra do Paraguai, serena e friamente analisada, mostrou pelo próprio desencadear dos acontecimentos, a situação lamentável de fraqueza dos partidos políticos do Império"275. Esta situação ganharia contornos nítidos após a aprovação da Lei do Ventre Livre, em 1871, momento em que os dramas políticos surgidos em 1868 se aprofundariam, evidenciando todos os dilemas do sistema partidário brasileiro. Ademais, a participação direta do imperador na aprovação da lei foi entendida pelos

\footnotetext{
${ }^{272}$ Leslie Bethell. "O Brasil no Mundo". Tradução de Denise Bottmann. In: José Murilo de Carvalho (coord.). A construção nacional (1830-1889) - volume 2. Rio de Janeiro: Objetiva; Madri: Fundación Mapfre, 2012, p. 141

${ }^{273}$ Vicente Licínio Cardoso. “À margem do Segundo Reinado”. Op. cit, p. 76.

${ }^{274}$ Vicente Licínio Cardoso. "À margem do Segundo Reinado". Op. cit, p. 75.

${ }^{275}$ Vicente Licínio Cardoso. “À margem do Segundo Reinado”. Op. cit, p. 76.
} 
proprietários como traição, a eles e aos interesses do país. Os efeitos negativos não se restringiram somente ao imperador; para o sistema político as consequências também foram desestabilizadoras. Vicente Licínio Cardoso, comentando a vida política dos primeiros anos do Segundo Reinado, afirma que a aproximação entre os partidos faziase sem problema, pois eram os interesses econômicos das elites dirigentes que ditavam a política brasileira; e onde se lê "interesses econômicos", entenda-se manutenção do trabalho escravo: "havendo sido o negro escravizado o movimentador oculto dos partidos, fica suficientemente claro que não havia propriamente ideias políticas de vitória"; logo, não havia um debate propriamente estabelecido. ${ }^{276}$ Dessa maneira, ao se retirar o elemento escravo do campo comum, era preciso rearranjar a relação de forças político partidárias; ao se mudar o regime de trabalho, ficava evidente a debilidade política; ao balançar as bases, o superficial se desorganizava.

Sobre esse assunto, note-se o que escreveu, no mesmo ano de 1925, Oliveira Vianna, o que demonstra como havia, neste ano de celebração, um senso crítico em relação ao Segundo Reinado, mesmo que feito por vias distintas. Em seu estudo sobre $O$ ocaso do Império, Vianna entendeu o enfraquecimento das disputas partidárias como algo congênito à própria política brasileira. Segundo o sociólogo, o sistema partidário carecia de significação prática; o fato de não só as leis abolicionistas, mas de todas as grandes reformas liberais do Império - eleição direta, reforma judiciária, leis de emancipação da mão de obra escrava - terem sido aprovadas por gabinetes conservadores era uma prova disso, um sinal de que o idealismo utópico estava impregnado em ambos os partidos, e em todos os grupos sociais; inclusive nos grandes proprietários de terras as utopias estariam presentes, isso por conta da ação dos filhos “doutores", que haviam estudado nas Faculdades de Direito de São Paulo ou Recife. Para Vianna, os partidos não atuariam, no Brasil, pela disputa de ideias e implementação de projetos; a política seria, acima de tudo, um jogo de apadrinhamentos e disputas entre clãs, cujo objetivo seria ocupar a máquina do Estado:

entre nós a política é, antes de tudo, um meio de vida: vive-se do Estado, como se vive da Lavoura, do Comércio e da Indústria - e todos acham infinitamente mais doce viver do Estado do que de outra coisa. ${ }^{277}$

Daí a importância central do imperador, que deveria ser o símbolo de poder que estivesse acima dos clãs e das divisões regionais. A questão é ambígua, pois, ao mesmo

\footnotetext{
${ }^{276}$ Vicente Licínio Cardoso. “À margem do Segundo Reinado”. Op. cit, p. 75.

${ }^{277}$ Oliveira Vianna. O ocaso do Império. Recife: FUNDAJ, Editora Massangana, 1990, p. 42.
} 
tempo em que, para Vianna, os grandes proprietários representavam a particularidade nacional construída durante a colônia, a partir da independência, com a formação do Estado-Nacional, era preciso contê-los em nome da unidade, esse o fato que os idealistas utópicos não conseguiam compreender. ${ }^{278}$ As reformas deveriam, portanto, ser um sistema de freios e contrafreios capazes de aproveitar o que há de melhor no clã, assim como de eliminar suas mazelas.

Indo adiante na questão dos partidos, Oliveira Vianna entendia o problema como sendo mais profundo do que uma mera questão de lances e jogadas políticas; para ele, na sociedade brasileira do século XIX, não existia opinião nacional, pois não existia espírito público, nem liberdade civil ou organização de classes. Consequência disso, aqueles que acorriam às urnas iam sem consciência de seu papel, alienados de qualquer pertencimento de classe, quando não intimidados por "caudilhos territoriais" - Vianna chega inclusive a entender que o censo econômico deveria ter sido mais excludente durante todo o período imperial. A partir dessa perspectiva, o processo eleitoral não tinha "uma significação realmente democrática" e a vida política concentrava-se numa classe única, "a grande aristocracia rural". Segundo Vianna, "esta preponderância tão absorvente da grande aristocracia da terra fazia com que nem a classe média rural, nem a plebe dos campos tivesse, ou pudesse ter, opinião"; mais do que isso, fazia os interesses das classes populares e senhoriais acordarem-se - evidentemente, essa comunhão não se dava de forma corporativa. No cenário urbano, repetia-se a mesma estrutura social, pois conflitos como os emergentes nas sociedades industriais não tinham razão de ser no Brasil. Em síntese:

pela grande simplicidade da nossa estrutura social; pela ausência de antagonismo de classes; pela feição acentuadamente patriarcal da nossa sociedade, a "opinião do povo", sob o $2^{\circ}$ Império, estava ainda em condição muito rudimentar. $\mathrm{O}$ processo de sondagem por meio das eleições não podia trazer, pois, ao Imperador nenhum elemento seguro de orientação ${ }^{279}$.

Apesar de excluir peremptoriamente a participação popular do jogo político e delimitar como campo de análise somente as vias oficiais de expressão e participação

\footnotetext{
${ }^{278}$ Nesse sentido, é importante compreender que, de acordo com Nilo Odália, para Oliveira Vianna, os idealistas utópicos realizavam meras especulações sem base cientifica. "É essa fé na ciência como um instrumento de racionalidade que leva Oliveira Vianna a, recorrentemente, insistir naquilo que o diferencia, como um idealista orgânico, daqueles que, por desconhecerem a realidade histórica de nosso país, persistirem em ter ilusões quanto à possibilidade de adaptar às nossas condições societárias modelos de organização social e política importados; são os idealistas orgânicos". Nilo Odália. As formas do mesmo. Op. cit, p. 125.

${ }^{279}$ Oliveira Vianna. O ocaso do Império.Op. cit, 1990, pp. 35 e 36.
} 
políticas - vias que ele mesmo deslegitima, apontando a sua inadequação para o contexto brasileiro -, a argumentação de Oliveira Vianna não deixa de ser incômoda em um sentido, pois evidencia a elitização da vida política do Segundo Reinado. ${ }^{280}$ A ideia de República, portanto, não teria, no raciocínio de Vianna, embasamento ideológico e nem substrato humano, porque não havia povo para essa suposta República. De acordo com o sociólogo, “onde o pensamento republicano podia encontrar campo propício de germinação era na elite cultivada das capitais e das cidades importantes, no patriarcado da riqueza e da cultura, nos quadros da direção dos partidos, nos centros universitários e literários", nas "classes de letrados inexperientes, cheios de entusiasmo juvenil, mas sem grandes responsabilidades sociais". ${ }^{281}$ Dessa forma arremata o autor, clamando contra modismos e ideologias de ocasião; a ação republicana dos militares também seria questionada, pois estava baseada, essencialmente, na crença cientificista do positivismo, não "lhes era dada por nenhum grande movimento da opinião nacional"; tramara-se o golpe contra os "casacas" civis e indisciplinados nos "bastidores dos quartéis", sem qualquer rescaldo na opinião pública. Faltaria para o Brasil, então, uma oligarquia, uma elite efetivamente nacional; só assim - Vianna flerta com uma centralização autoritária -, e não com iniciativas populares ou de bacharéis pomposos, seria efetiva a mudança de regime.

De forma parecida (mas não igual) Licínio Cardoso, tratando da vida política, chamou atenção para a "inércia do meio" brasileiro - no qual as iniciativas educacionais (tanto ensino escolar quanto profissional) eram limitadíssimas e a opinião nacional bastante acanhada -, e para a encenação parlamentar do Segundo Reinado, na qual teriam acreditado muitos "historiógrafos", sem terem percebido a miragem enganadora que era esta vida política imperial, mero mimetismo de letras, instituições e livros.

\footnotetext{
${ }^{280}$ Nelson Werneck Sodré, que tinha uma interpretação distinta da de Vianna sobre o Segundo Império, também entendia que faltavam princípios fortes nos quais basear a opinião pública, o que gerava uma vida política verborrágica e vazia de sentido: "Um dos males que afligiu o regime findo em quinze de novembro de 89 foi, certamente, essa ausência de princípios fortes e básicos, a orientar as campanhas de opinião e a arregimentar as forças vivas do país, a sua produção agrícola e o surto das iniciativas que constituiriam a nossa incipiente indústria. Nem se caracterizava a existência dos partidos que ornamentaram a vida do segundo império pela luta sem desfalecimentos em defesa de certos postulados políticos a que se subordinassem, que marcassem a trajetória de cada um deles. [...] É por isso que a história do segundo império é uma continuidade de transigências e de abdicações. É por isso que esses partidos, anteriormente tão fortemente apoiados, diluem-se numa temperatura morna, onde prevalecem os conceitos externos, os conceitos copiados, as atitudes humílimas ante a sapiência de uma citação, as acomodações, não tanto para ajudar o regime e a coroa, mas para alicerçar situações provinciais, para suportar prestígios locais e supremacias em declínio". Nelson Werneck Sodré. Panorama do Segundo Império. Op. cit, pp. 145 e 146.

${ }^{281}$ Oliveira Vianna. O Ocaso do Império. Op. cit., 1990, pp. 91 e 98.
} 
Teriam, os historiadores, dado vazão a esse bacharelismo vazio, vício de uma sociedade escravocrata, para a qual a menor profissionalização é motivo de calafrios e desconforto. Admirados com debates vazios e personalidades pomposas, teriam os intérpretes se esquecido

das necessidades sociais ocultas e profundas, mal dissimuladas nos princípios e nas ideias dominantes na época, já por si difíceis de serem focalizadas, dado o feitio simplista costumeiro dos que, historicamente, bordam comentários à vida dos organismos sociais. ${ }^{282}$

D. Pedro II, sob o viés crítico de quem pensa as necessidades "ocultas e profundas", não foi o imperador que o Brasil precisava; essa, a opinião de nosso autor. Mesmo com todas as suas possíveis qualidades e valores, "falhou como realizador político em nosso meio"; faltou-lhe iniciativa e sistematização, o tato para aplicar em seu país algumas das inovações tecnológicas que tanto conhecia. A crítica, a certa altura, assume uma feição, por assim dizer, mais bem humorada:

Cético por não poder ser pessimista, visceralmente bom, honesto, sem nenhum esforço ou alarde, liberal por ser tolerante, tolerante por ser culto, Pedro II teria sido admirável governando a Inglaterra: teria sido talvez o melhor e o maior monarca de todos os tempos, de todas as raças ${ }^{283}$.

No Brasil, ao contrário da Inglaterra, era preciso construir um Estado nacional e governar com organização, cercar-se de gente comprometida e atuante; Pedro II o fez nos casos (importantes, apesar de restritos ao campo da oficialidade) do escritor Gonçalves de Magalhães, do pintor Pedro Américo e do músico Carlos Gomes. No entanto, deixou a desejar - e muito, para quem ficou quase meio século no poder naquilo que diz respeito a reformas sociais e econômicas. Licínio Cardoso chega a aventar a imagem mutante de um imperador ideal:

O Brasil carecia da cultura de José Bonifácio, da energia de Diogo Feijó e da crença de Pedro II, para com eles fundir a figura complexa de modelador de sua nacionalidade. A cultura do patriarca, porque ela era de fato grande, sólida e sadia, embebida que estava nas ciências naturais compendiadas em seu tempo; a energia de Feijó, por ter sido eloquentemente vigorosa num momento por demais crítico de nossa história; a crença de Pedro II no Brasil, porque ela foi tão serena e confortadora, que constituiu a sua própria religião, a finalidade, em suma, de sua vida. Espanta, em verdade, a fidelidade do crente. [...] Foi o único monarquista que respeitou a República, nos dias ingratos dos primeiros anos. Não perdeu a compostura cívica de seus ideais, nem a linha elegante de suas crenças. ${ }^{284}$

\footnotetext{
${ }^{282}$ Vicente Licínio Cardoso. “À margem do Segundo Reinado”. Op. cit, pp. 81 e 82.

${ }^{283}$ Vicente Licínio Cardoso. "À margem do Segundo Reinado”. Op. cit., pp. 94 e 95

${ }^{284}$ Vicente Licínio Cardoso. "À margem do Segundo Reinado”. Op. cit., p. 97.
} 
Nessa curiosa criatura - na qual faltou só lembrar o empreendedorismo de seu admirado Mauá: “o caso é que, se a mentalidade de Pedro II tivesse o vigor constitutivo da cerebração de Mauá, teríamos constituído um caso de evolução interessantíssima”"285 - fica bem clara a filiação republicana e o ranço de politécnico, a sua crença progressista: era exigência do momento um governante enérgico e sábio, que coordenasse um programa de reconhecimento do Brasil - o próprio Licínio Cardoso realizou, no ano de 1923, aquela sua viagem por todo trajeto do rio São Francisco para, a partir do conhecimento empírico e não só teórico, explorar suas riquezas naturais, modificar investimentos, modernizar a economia e pôr fim ao trabalho escravo. A missão, sem dúvida, era árdua; difícil foi manter-se otimista.

Para Licínio Cardoso, em uma conclusão, talvez, até certo ponto rigorosa, o que Pedro II fez foi fingir que governava, isso durante quase cinquenta anos - lembre-se que, anos depois, Heitor Lyra vai desconstruir essa ideia. Cardoso afirma, ainda, que seu governo foi fictício; de tanta leitura feita, o imperador acreditou que reinava em um país de homens cultos - Oliveira Lima, anos antes, comentando o mesmo assunto, carregava nas tintas positivas e moderadas ao dizer que o imperador, em detrimento da prática, sempre foi marcado por certa "impulsão teórica", daí porque, ao mesmo tempo em que foi o verdadeiro caráter democrático da sociedade brasileira, efetivo déspota da

\footnotetext{
${ }^{285}$ Vicente Licínio Cardoso. "À margem do Segundo Reinado". Op. cit., p. 92. A questão do empreendedorismo, principalmente quando se fala de Irineu Evangelista de Souza, barão e visconde de Mauá, deve ser tratada com cautela, isso porque há o risco de se fazer um personalismo às avessas. $\mathrm{O}$ notável livro de Jorge Caldeira, Mauá: empresário do Império, é um exemplo dessa postura. Na bem articulada narrativa do autor, d. Pedro II e Irineu disputam para decidir quem é o verdadeiro imperador do Brasil. O monarca representa a vontade de poder absoluto, o atraso econômico, é inimigo do progresso, mas amante da civilização, da astronomia, da ópera, etc.; para ele, as exigências do momento seriam grandes e desinteressantes maçadas. $\mathrm{O}$ segundo, o empreendedorismo em pessoa, a iniciativa inteligente $\mathrm{e}$ o futuro, o visionário incompreendido e que lutava contra a corrente, pisava onde ninguém ousara e estava acima de disputas partidárias. Trata-se do empresário que ia contra uma estrutura de mentalidade e enfrentava as dificuldades: "a verdade é que Mauá não conseguira enraizar seus negócios na base fofa de um país escravista, onde o mercado era ralo e dependente do governo, e onde os homens de fortuna queriam o progresso que não colocasse em risco seus privilégios - e a mina de ouro dos fazendeiros endividados" (Jorge Caldeira. Mauá: empresário do Império. São Paulo: Companhia das Letras, 1995, p. 414). D. Pedro II, é certo, não era o maior dos entusiastas pelas mudanças - fato constatado, tido como um de seus poucos defeitos, até mesmo por Oliveira Lima: "não obstante suas maneiras democráticas, atinha-se ao Brasil como prolongamento do passado, a um Brasil fortificado pela defesa de suas glórias e pela vibração ininterrupta de seus sofrimentos" (Oliveira Lima. Formação histórica da nacionalidade brasileira. Op. cit., p. 232). No entanto, ao invés de opostos, talvez seja o caso de pensar d. Pedro e Mauá como duas faces de uma mesma moeda. Mais do que lutar contra a corrente, o que Mauá fez foi encontrar meios de investimento nas brechas deixadas pela inserção do Brasil na economia mundial, muitas vezes com auxílio e financiamento do próprio Estado. Assim, seus projetos, tomados como incompreendidos, nasciam viciados pela própria estrutura econômica brasileira, daí serem sempre malfadados; o problema é entender como esses projetos só existiam porque inseridos nessa mesma estrutura. Portanto, é importante ter consciência de que, se há mitos e memórias sobre d. Pedro II, esses também existem para Mauá, aos montes.
} 
moralidade e quase um "modelo perfeito de realeza", faltou-lhe "a decisão dos grandes homens de Estado". ${ }^{286}$ A crítica de Licínio Cardoso evidencia um dos riscos da estratégia de governo de Pedro II, algo recorrente nos últimos anos de seu regime, quando da emergência do monarca de casaca e cartola: o de ser entendido como um diletante despreocupado. O desinteresse político, dessa forma, cruza o limite e deixa de ser um aspecto positivo; passa, pelo contrário, a ser motivo de críticas e condenações, quando não de chistes e pilhérias. ${ }^{287}$

O esforço analítico de Vicente Licínio Cardoso é o do intérprete que se pensa à margem do pensamento estabelecido, formulando, dessa perspectiva, uma reflexão crítica e propositiva, permeada pelos dilemas de seu tempo. Para ele, a política de Pedro II foi ineficaz - assim como os idealistas utópicos o foram para Oliveira Vianna - em realizar mudanças profundas e necessárias; além do mais, foi conservadora, manteve a unidade nacional, conciliou as elites e prolongou o trabalho escravo até o ponto em que este ficou incompatível com a existência do Império, até o momento em que precisaram mudar as formas conservadoras. $\mathrm{O}$ autor parece ter percebido, de forma bastante arguta, que a economia brasileira da segunda metade do século XIX viveu um processo de modernização conservadora e pautado por surtos de crescimento, o que não significou efetivo desenvolvimento; este, afinal, só ocorre quando, como lembra o economista João Antônio de Paula, o conjunto da sociedade usufrui de seus benefícios, não se

\footnotetext{
${ }^{286}$ Oliveira Lima. Formação histórica da nacionalidade brasileira. Op. cit., p. 205. Mais adiante, diz ainda o historiador pernambucano: "Se sua influência tivesse sido tão real e eficaz sobre a orientação das mais importantes questões de governo quanto sobre as minudências da administração - o que era o caso, ainda que ele possuísse ideias gerais, mais do que revelava o gênio dos negócios públicos -, D. Pedro II teria deixado impressão de um grande homem de Estado e não apenas de um grande homem de bem. Foi a esse último título que deveu ser um soberano notável" (p.206).

${ }^{287}$ Pouco tempo depois de Vicente Licínio Cardoso publicar seu texto, Paulo Prado, em Retrato do Brasil, pensava o reinado de d. Pedro II nos seguintes termos, aproximando-se das ideias do primeiro crítico e mostrando como, na época, consolidou-se, fora dos círculos "áulicos", uma determinada forma de interpretação: "Em seguida ao Primeiro Reinado, período heroico em que se fundou num ímpeto romântico a nossa nacionalidade - entramos nesse estranho Segundo Reinado de homens eminentes, ilustrados (apesar do acentuado atraso português), de ilibado caráter, mas que passaram cinquenta anos a representar, com seriedade e numa terra que era um deserto com povoados esparsos de população mestiças, a comédia do parlamentarismo à inglesa. Além das leis liberais, que eram votadas como se destinassem ao mais esclarecido dos condados da Inglaterra, e além dos discursos de admirável eloquência parlamentar, só nos ficou, talvez, dessa época falsa e estéril, a consolidação da unidade nacional e a abolição. Apenas duas datas para um longo reinado. O país desconhecia geralmente o que fosse administração pública. O imperador, pouco inteligente, substituindo pelo patriotismo o que the faltava em dotes de homem de Estado, não escondia o desprezo pelas preocupações terra a terra da gestão dos negócios públicos. Deu-lhes, porém, uma feição característica, que é a glória da monarquia: o respeito religioso do dinheiro público". Paulo Prado. Retrato do Brasil. São Paulo: Companhia das Letras, 2012, pp. 140 e 141.
} 
caracterizando por ser heterogêneo, fragmentário e seletivo. ${ }^{288}$ Além de entusiasta da ideia de república, Licínio Cardoso condenou, apoiado nos escritos de Tavares Bastos, o excesso de centralismo do Segundo Império, o que teria criado um governo fictício e desarticulado da realidade nacional; pensa em uma república ilustrada e com força produtiva diversificada e moderna, distante do legado colonial. Essa República, é certo, não fora empregada no Brasil a partir de 1889, pois o que se viu aqui foi um regime marcado pela especulação financeira e pelo predomínio da agricultura exportadora; o problema, para o nosso autor, portanto, não estava em um federalismo descentralizado, e sim na política econômica, que ainda mantinha o país no modelo do Segundo Reinado.

\section{2. 2. Capistrano de Abreu: outra sorte de espinhos, espinhos do sertão}

"O ideal da história do Brasil seria uma em que o lugar ocupado pelas guerras flamengas e castelhanas passasse aos sucessos estranhos a tais sucessos. Talvez nossos netos consigam ver isso".

Capistrano de Abreu, em carta a João Lúcio de Azevedo, 14 de setembro de 1916

Em 1845, a revista trimestral do Instituto Histórico e Geográfico Brasileiro publicou um breve texto de Carl F. P. von Martius (1794-1868) - botânico bávaro, integrante da missão científica que percorreu o Brasil, do Rio de Janeiro ao Amazonas, durante os anos de 1817 e 1820. Tal ensaio, que seria vencedor de um concurso realizado, dali a dois anos, pelo próprio IHGB, versava sobre um assunto de grande importância para uma jovem nação: "Como se deve escrever a história do Brasil" - o título, em si, já é bastante claro - representou o alicerce sobre o qual se fundou a historiografia produzida pelo Instituto. No artigo, tema dos mais comentados, von Martius lançou as bases daquilo que ficaria conhecido como o mito da "democracia racial” brasileira. Segundo José Carlos Reis, "para ele, a identidade brasileira deveria ser buscada no que mais singularizava o Brasil: a mescla de raças". ${ }^{289}$ No entanto, essa mescla teria sempre o elemento branco como o fator preponderante; para se explicar, o

\footnotetext{
${ }^{288}$ João Antônio de Paula. "O processo econômico". In: José Murilo de Carvalho (coord.). A construção nacional (1830-1889). Op. cit., p. 222.

${ }^{289}$ José Carlos Reis. As identidades do Brasil-de Varnhagen a FHC. Rio de Janeiro: Ed. FGV, 2005, $7^{\mathrm{a}}$. Edição, p. 26.
} 
botânico utilizou uma metáfora interessante, bem adaptada à natureza brasileira, o seu tema principal de estudo: "O sangue português, em um poderoso rio, deverá absorver os pequenos confluentes das raças índias e etiópicas". ${ }^{290}$ Por baixo da aparente naturalidade, percebe-se uma proposta de formação de uma sociedade de matriz europeia; isso fica mais bem especificado ao se tomar conhecimento dos outros pontos que o cientista julgava importantes para a escrita dessa história: "uma obra histórica sobre o Brasil deve, segundo a minha opinião, ter igualmente a tendência de despertar e reanimar em seus leitores brasileiros amor à pátria, coragem, constância, indústria, fidelidade, prudência, em uma palavra, todas as virtudes cívicas"; deve, também, ressaltar a "necessidade de uma Monarquia em um país onde há um tão grande número de escravos"; incentivar o sentimento de unidade nacional e, muito importante, "deverá ser escrita em estilo popular, posto que nobre". ${ }^{291}$ A proposta de von Martius, portanto, na maioria de suas colocações, atendia bem aos interesses vislumbrados pelo IHGB: uma dissertação objetiva, pautada em exemplos claros e pragmáticos, que ressalte a importância do elemento branco-europeu, valorize a monarquia e o cristianismo, tudo feito através de um discurso escrito em "estilo popular, posto que nobre", o que, dessa maneira, poderia garantir um alcance considerável entre o público leitor e servir de modelo patriótico.

Publicada entre 1854 e 1857, a História Geral do Brasil, de Francisco Adolfo de Varnhagen (1816-1878), acabaria se consolidando como uma aplicação de parte das ideias de von Martius; mais que isso, seria considerada a história do Brasil, aquela que serviria de base para a historiografia tradicional e para o ensino predominante nas escolas. Nessa obra pode-se perceber a influência marcante do historicismo alemão e um trato refinado com a documentação. Foi exatamente este aspecto formal - e também o discurso de caráter oficial - que lhe garantiu a fama de marco da historiografia brasileira; mesmo que tivessem existido narrativas anteriores, nenhuma era tão completa, tão documentada e confiável. A obra monumental de Varnhagen é um efetivo desfile de nomes ilustres, datas e acontecimentos - desde a colonização realizada pelo homem branco nos trópicos, até o Segundo Reinado, ápice da formação nacional. O indígena é tratado como um selvagem e inimigo do Estado; uma ameaça à civilização, que precisava ser combatida e controlada. O negro, como já era de se esperar, recebe o

\footnotetext{
${ }^{290}$ Carl F. P. von Martius. "Como se deve escrever a história do Brasil". In: O estado do direito entre os autóctones do Brasil. Belo Horizonte: Ed. Itatiaia, p. 88.

${ }^{291}$ Carl F. P. von Martius. "Como se deve escrever a história do Brasil". Op. cit, p. 106 e 107.
} 
mínimo de atenção, apenas o necessário para caracterizá-lo como um ser bárbaro e inferior ao branco. Este último é o grande personagem da História de Varnhagen - o rio caudaloso, como diria von Martius. Num esforço de tentar realizar uma compilação geral de nosso passado, o historiador narra acontecimentos que elevam o colonizador europeu ao posto de herói, de civilizador.

Essa proposta interpretativa, no entanto, apesar de largamente aceita, não passaria sempre incólume. Foi na cidade de Maranguape, sertão do Ceará, num ambiente bastante diverso da corte, que nasceu, em 1853, João Capistrano de Abreu, aquele que seria responsável pela primeira obra historiográfica de vulto a seguir uma direção oposta às diretrizes lançadas pelo IHGB. A formação intelectual de Capistrano é considerada uma verdadeira façanha, o que cria certa aura ao redor de sua figura. Para alguém nascido no sertão do Ceará, nos idos do século XIX, e criado num ambiente de rigidez e severidade, marcado pela figura autoritária do pai e pelo dogmatismo católico, as perspectivas que se abriam não eram das mais animadoras; a vida, quase que naturalmente, se limitaria ao trabalho duro e exaustivo da roça. Entretanto, as coisas foram diferentes; alfabetizado no próprio sítio da família, Capistrano frequentou, depois, sempre de modo instável, o Ateneu Cearense, em Fortaleza. Posteriormente, tentaria ingressar na Faculdade de Direito de Recife; sua dificuldade com os exames, porém, o impediu de continuar. Acabou tendo de voltar a Maranguape, onde não poderia ficar sem ter de trabalhar na lavoura. A solução foi migrar para a corte. No ano de 1875, Capistrano - que "era psíquica e fisicamente um autêntico sertanejo, um caboclo matuto, feio, agreste, desagradável: 'Um desconfiado tapuia transplantado para o meio civilizado', alguém disse" 292 -, chegava ao Rio de Janeiro, trazendo consigo boa bagagem intelectual, adquirida, na sua maioria, com estudos realizados de maneira autodidata. Trazia, também, uma carta de recomendação feita por seu ilustre conterrâneo, o escritor José de Alencar (1829-1877), a quem tivera a ocasião de conhecer. Na corte, conseguiu um emprego público estável e seguro: passara no concurso para preenchimento de uma vaga na Biblioteca Nacional. O ofício era talhado para a pessoa: avesso ao convívio social, poderia passar horas estudando sozinho, os livros bem próximos, nas próprias estantes da Biblioteca. Chegou a lecionar no Colégio Pedro II, um cargo, à época, de grande relevância; porém, a passagem foi rápida: sua cátedra, História do Brasil, havia sido extinta e incluída na História Universal. Além do

\footnotetext{
${ }^{292}$ José Carlos Reis. As identidades do Brasil. Op cit., p. 86.
} 
mais, o convívio com os alunos não agradava o historiador cearense. Capistrano de Abreu faleceria em 1927, na cidade do Rio de Janeiro.

Sua obra mais comentada, Capítulos de História Colonial, foi lançada no início do século XX, em 1907. Nela fica nítido que o seu Brasil era outro, distante da corte e da costa, ficava nos confins do território, no sertão. Era no interior do país que se tinha formado o verdadeiro brasileiro, era lá, nessa terra onde o indígena e o mestiço mostravam o seu valor, que se deveria pesquisar a formação nacional. O livro, por assim dizer, assume uma verdadeira função de "história de guerrilha": dividido em onze capítulos que, apesar de sempre parecerem um projeto para uma futura história do Brasil, são ágeis como pequenos grupos que podem desmontar com mais facilidade a historiografia tradicional, abrir novas veredas na selva fechada dos acontecimentos políticos e militares, tendo sempre à frente o caboclo Capistrano que, facão em punho, vem cortando o mato virgem. Isso é um fato notório: cada capítulo joga uma nova perspectiva sobre o tema que aborda; cada um parece ser um pequeno manifesto sobre a necessidade de se dar um novo enfoque à história do Brasil, sobre a necessidade de romper os "quadros de ferro" da historiografia brasileira. ${ }^{293}$ A título de exemplo, tomem-se os dois primeiros capítulos da obra em questão. “Antecedentes indígenas", o primeiro deles, caracteriza-se por ser, em sua maior parte, uma descrição dos aspectos naturais do Brasil: vegetação, clima, hidrografia, fauna, relevo, todos os fatores geográficos entram nessa descrição. Apenas uma parte do capítulo é dedicada à abordagem antropológica dos povos que aqui viviam antes de 1500; porém, mesmo

\footnotetext{
${ }^{293}$ Em carta ao seu amigo Rio Branco, datada de abril de 1890, Capistrano assim se referia a seu projeto de escrever uma história do Brasil, que resultaria, anos depois, nos Capítulos: "escrevo-a porque posso reunir muita coisa que está esparsa, e espero encadear melhor certos fatos e chamar atenção para certos aspectos até então menosprezados. Parece-me que poderei dizer algumas coisas novas e pelo menos quebro os quadros de ferro de Varnhagen que, introduzidos por Macedo no Colégio de Pedro II, ainda hoje são a base de nosso ensino. As bandeiras, as minas, as estradas, a criação de gado pode dizer-se que ainda são desconhecidas, como, aliás, quase todo o século XVII, tirando-se as guerras espanholas e holandesas". No ano de 1878, no necrológio que escreveu a Varnhagen, que morrera agraciado pelo título de Visconde de Porto Seguro, Capistrano expressa, de acordo com José Honório Rodrigues, como principal defeito do autor da História Geral do Brasil a falta de espírito plástico e simpático. Na nota fúnebre, se lê o seguinte: "A história do Brasil não se lhe afigurava um todo solidário e coerente. Os pródromos da nossa emancipação política, os ensaios de afirmação nacional que por vezes percorriam as fibras populares, encontram-no severo e até prevenido. Para ele, a Conjuração mineira é uma cabeçada e um conluio; a Conjuração baiana de João de Deus, um cataclisma de que rende graças à Providência por nos ter livrado; a Revolução pernambucana de 1817, uma grande calamidade, um crime em que só tomaram parte homens de inteligência estreita, ou de caráter pouco elevado. Sem D. Pedro a independência seria ilegal, ilegítima, subversiva, digna da força ou do fuzil. Juiz de Tiradentes e Gonzaga, ele não teria hesitado em assinar a mesma sentença que o desembargador Diniz e seus colegas". Capistrano de Abreu. Capitulos de história colonial (1500-1800). Edição anotada e prefaciada por José Honório Rodrigues. Belo Horizonte: Itatiaia; São Paulo: Publifolha, 2000 (Coleção Grandes nomes do pensamento brasileiro), p. 3 e p. 22.
} 
pequena, é rica ao comentar os usos e costumes dos habitantes nativos. Merecem destaque a antropofagia, a vida em pequenas comunidades, o "talento artístico" (produtos em cerâmica, trançados, pinturas em cuias, máscaras, adornos, danças e músicas) e as línguas (que permitiram à etnografia moderna conseguir agregar em grupos certas tribos mais ou menos conexas entre si). No segundo capítulo, "Fatores exóticos", ainda se observam descrições dos aspectos culturais, neste caso, de brancos e negros. Ponto mais relevante: o historiador transforma o branco em elemento exótico (o negro também não pertencia a este continente, era uma consequência da vinda do homem branco). As índias, sem vergonha de estar com suas vergonhas à mostra, e a pureza dos habitantes nativos do Novo Mundo, fatos que muito haviam espantado o velho Caminha, não seriam mais, de acordo com nosso autor, os fatores exóticos; o elemento estranho passava a ser o europeu, completamente alienígena a essas terras.

Capitulos de História Colonial ganha novos contornos quando entra na análise da conquista do sertão; como diz José Carlos Reis, "seu [de Capistrano] grande tema foi a ocupação do território, a sua conquista pelo novo povo brasileiro". ${ }^{294}$ Mas por que, pode-se perguntar, tanta relevância dada à ocupação do interior do território? Porque o sertão fugia às discussões "exóticas" e alienígenas tão vigentes no litoral, destoava da normalidade da colonização, escapava aos interesses econômicos coloniais europeus. Se havia uma identidade brasileira, era lá, nos recônditos da colônia, que ela estaria. Nesse sentido, o bandeirante, exemplar típico de mameluco, ganha papel fundamental: filho de pai branco e mãe índia, de hábitos rudimentares e gênio forte, é a figura do caboclo que fugia do elemento europeu, ao mesmo tempo em que também não era índio. Era um homem novo, fruto da dominação "exótica" em terras tropicais, capaz de desbravar um continente desconhecido e selvagem; era a contradição concentrada em um único indivíduo. No entanto, a ação dos bandeirantes não passará batida pelo sempre incisivo questionamento do nosso autor: "compensará tais horrores [cometidos durante as bandeiras] a consideração de que por favor dos bandeirantes pertencem agora ao Brasil as terras devastadas?". 295

O último capítulo, diretamente ligado ao que trata do sertão, é o mais inovador; nele podemos observar claramente a posição contrária de Capitulos de História Colonial à historiografia vigente à época, herdeira daquela feita pelo Instituto Histórico

\footnotetext{
${ }^{294}$ José Carlos Reis. As identidades do Brasil. Op cit., p. 96.

${ }^{295}$ Capistrano de Abreu. Capítulos de história colonial (1500-1800). Op. cit., p. 131.
} 
Brasileiro e por Varnhagen. Em "Três séculos depois", o autor dá sua visão sobre a colonização portuguesa no Brasil, um panorama que vai até o início do século XIX. Para fazer isso, deixa de lado os grandes nomes da história e mergulha na vida cotidiana da colônia, nos trazendo descrições precisas dos usos e costumes, do porte físico, da alimentação, das festas, e de tantas outras coisas que estavam ligadas ao dia a dia. Através de sua descrição, pode-se notar que a colônia se trata de um lugar onde os senhores andavam de ceroulas, as crianças nuas e descalças, onde se comia com as mãos, onde medrava a miscigenação e vivia uma população cuja "maioria constava de mestiços". ${ }^{296}$ O fato mais relevante que podemos observar dessa descrição é que o Brasil, em vias de se tornar independente, era um país extremamente dividido: cada região possuía sua própria cultura, seu próprio ambiente, seus próprios habitantes; o que quer dizer que, com a colonização, não havia se criado um profundo senso de unidade entre a população do vasto território.

Curiosamente, aquele que tentou romper os "quadros de ferro" de Varnhagen foi quem fez melhor audiência a uma lição de von Martius, deixada de lado pela história oficial. O cientista bávaro, em seu texto sobre como se deveria escrever a história do Brasil, já salientara a importância de se estudar a diversidade da cultura popular que se desenvolvera no Brasil. Capistrano dá voz ativa em seu texto às cantigas, trovas, festas e provérbios populares, faz o que nenhum outro historiador oficial havia feito: dialoga com a cultura popular. Os relatos de viajantes estrangeiros que estiveram no Brasil durante o século de XIX, incluso o próprio von Martius, foram de grande ajuda para o autor cumprir a tarefa. O texto chama atenção pelo minucioso trato que Capistrano dedica a suas fontes, todas bem indicadas em notas de referência, o que garante o crédito de sua fala. No Brasil da virada do século XVIII para o XIX, o que existia era a diversidade, muito mais do que a unidade. Esta era a obra da colonização:

cinco grupos etnográficos, ligados pela comunidade ativa da língua e passiva da religião, moldados pelas condições ambientes de cinco regiões diversas, tendo pelas riquezas naturais da terra um entusiasmo estrepitoso, sentindo pelo português aversão ou desprezo, não se prezando, porém, uns aos outros de modo particular - eis em suma ao que se reduziu a obra de três séculos. ${ }^{297}$

Como interpretaria, um historiador tão peculiar, o reinado de d. Pedro II? Capistrano de Abreu, em 2 de dezembro de 1925, exatos cem anos de nascimento do imperador, publicou, no periódico carioca $O$ Jornal, o texto "Fases do Segundo

\footnotetext{
${ }^{296}$ Capistrano de Abreu. Capítulos de história colonial (1500-1800). Op. cit., p. 221.

${ }^{297}$ Capistrano de Abreu. Capítulos de história colonial (1500-1800). Op. cit., p. 242.
} 
Império", um breve ensaio que, na mesma lógica do texto de Vicente Licínio Cardoso, toma a efeméride como motivo para, não só tratar do próprio d. Pedro II, mas de todo o seu reinado - ressalte-se que este texto foi republicado, postumamente, em 1938, no livro Ensaios e estudos, $3^{a}$ série, o que quer dizer que se enquadra nos critérios estabelecidos para a seleção de obras neste capítulo. Capistrano começa tratando da partida de d. Pedro I e dizendo que, "o fundador do império" acertou, no que diz respeito aos interesses da dinastia, em legar o filho aos cuidados da tutoria de José Bonifácio; assim, "de um só golpe redimiam-se todos os erros e todas as culpas do reinado". Com a explosão das revoltas nos anos da Regência, quando, "de repente, o Brasil inteiro estrebuchou nas convulsões de um delírio muscular", a presença do jovem herdeiro foi fundamental, pois, se "a tudo resistiam os Regentes", isso se devia à "existência, por assim dizer, simbólica do imperador-menino" e à força "sobrenatural" que ele lhes transmitia; além disso, "o desinteresse com que se batiam colocou-os a coberto de desconfianças". Essa última afirmação revela um entendimento diferente, por exemplo, daquele que teria Heitor Lyra, que se preocupa tanto em demolir o mito dos Andradas, acerca dos políticos mais próximos ao menino. Pelo esforço dos regentes, "o Brasil apaziguou-se, o vírus subversivo atenuou-se, quase todo o país volveu ao aprisco e, até, foi perdendo a capacidade de novas revoluções". Capistrano ressalta como o Ato Adicional de 1834, que minorou "a centralização que sucedera ao regime colonial", foi positiva à Regência; não só por ter deliberado que, agora, ao invés de três, haveria só um regente, como por ter diminuído as atribuições deste, pois, "dando liberdade às províncias manietadas, munido-as de poder legislativo, dando-lhes atribuições que pareceram depois excessivas, facilitou a obra da regência, o caldeamento da unidade brasileira". ${ }^{298}$ Trata-se, esta, de uma leitura interessante: ao contrário dos defensores do centralismo, para Capistrano de Abreu, foi a descentralização o que permitiu ao poder central manter seu foco e garantir a unidade nacional. $\mathrm{O}$ ato adicional evitava boa parte dos problemas, "afastando causas de descontentamento". 299

Mesmo assim, não estavam findas as revoltas e, com a eleição do Marquês de Olinda - "amparado em Bernardo Pereira, mineiro tido pela mais forte cabeça política da época" - para o cargo de regente, tomou-se o caminho da reação; nesse novo cenário,

\footnotetext{
${ }^{298}$ Capistrano de Abreu. "Fases do Segundo Império". In: Ensaios e estudos: crítica e história, $3{ }^{a}$ série. Nota liminar de José Honório Rodrigues. Rio de Janeiro: Civilização Brasileira; Brasília: INL, 1976, p. 75. Uma reprodução da edição original pode ser consultada no site www.brasiliana.usp.br.

${ }^{299}$ Capistrano de Abreu. "Fases do Segundo Império". Op. cit., p. 76.
} 
"o ato adicional pareceu excessivo: a interpretação legislativa reduziu as fraquezas nele contidas". De acordo com o autor, os políticos que haviam sido deslocados do poder com a renúncia de Feijó, o regente anterior, "não podiam conformar-se com a ideia de que só em 1843 o imperador atingiria a maioridade e cessaria o período regencial"; como estavam afastadas as possibilidades da tomada do poder pela via das armas, "surgiu, então, a ideia de uma revolução palaciana em que o imperador mesmo entraria de comparsa". Nesse ponto se percebe como o autor escapa a qualquer idealização acerca da maioridade; d. Pedro não surge como um líder precoce e predestinado ao poder; pelo contrário, é um comparsa da articulação política que o colocaria no poder; articulação na qual, ressalta o autor, "o nome dos Andradas serviu de senha". O quero já ocorreu somente para confirmar o golpe que vinha em execução e para afastar qualquer possibilidade de contragolpe. O jovem herdeiro estava longe de tomar grandes decisões; à época, "vegetava no Paço de São Cristóvão com as duas irmãs pouco mais velhas"; aquele que poderia ter conduzido sua formação da melhor forma, José Bonifácio, "as facções dominantes arrancaram violentamente do paço". Assim seguia-se no passo de certo marasmo; segundo Capistrano, a d. Pedro se não faltaram mestres, "houve-os até demais". Dentre aulas de literatura, línguas estrangeiras, matemática e história contemporânea - nesta última matéria, frei Pedro, o professor, ressaltava "as estroinices que deram a grandeza e a decadência paterna: em uma só delas nunca incorreu" d. Pedro II - o autor chama a atenção para as aulas de direito constitucional; nelas, o mesmo frei Pedro, dosando a matéria para melhor adequá-la ao entendimento do menino, insistia sobre um dos artigos, o de número 98, justamente aquele que versava sobre o poder moderador. Com este artigo em mente desde os tempos de menino, "o imperador atravessou seu longo reinado". 300

No ensaio de Capistrano, o Segundo Reinado começa de maneira turbulenta, com troca de ministérios e "medidas reatoras", tais como o reestabelecimento do conselho de Estado, que fora dissolvido pelo Ato Adicional, a votação de "leis restritivas da liberdade individual" e o reforço do "organismo policial a ponto de tornálo irresistível". Contra essas medidas houve reação em São Paulo e Minas Gerais, além da continuidade dos conflitos no Rio Grande do Sul. Segundo nosso autor, ao longo desses "anos e anos de desordem", poderia ter ocorrido a fragmentação definitiva do país em diversas províncias; isso teria acontecido se não fosse a espada de Luís Alves

\footnotetext{
${ }^{300}$ Capistrano de Abreu. "Fases do Segundo Império". Op. cit., pp. 76-77.
} 
de Lima, "que da Balaiada trouxera o nome de Caxias, tomado a uma obscura cidade sertaneja, que não quis nunca permutar por outro mais vistoso ou mais sonoro". Foi ele que subjulgou as províncias rebeldes; o mais foi garantido por uma "anistia generosa", que "realçou a vitória da Ordem". ${ }^{301}$ A última das revoltas, rescaldo ainda dos tempos da regência, foi a Praieira, consequência do gabinete conservador de 1848, que, "com leves mudanças de rótulo e substituição de figurantes, durou até a era de 60". A derrota da revolta, rapidamente abafada no litoral, mas duradoura nas matas e catingas, na interpretação de Capistrano, era a "prova de quanto foi fecundo o regime regencial: novas revoluções tornaram-se impossíveis a beira-mar; só nas brenhas alongadas podiam rebentar e arrastar-se distúrbios, sem importância para a coletividade". ${ }^{302}$

A respeito das jogadas políticas que se seguiram nesses primeiros anos de Segundo Reinado, Capistrano faz observações interessantes; diz, por exemplo, que a resistência do imperador face aos seus opositores se dava não por meio de apoios políticos suspeitos, como o do suposto Clube da Joana, do qual faria parte Paulo Barreto da Silva, o mordomo imperial, e sim por conta da "repugnância imperial às injustiças". Isso não significa que não as cometesse, "mas o epíteto de redresseur de torts, assentava-lhe bem". Para Capistrano, daí advém "a confiança em sua retidão e integridade com que a multidão anônima o cercou até o fim". Na sequência, para melhor se explicar, vai ao nível do detalhe: “o lápis fatídico, o livro negro, a memória peregrina, herança dos Braganças, tolheram grandes gravames, valeram honrosas reparações, conferiram recompensas imprevistas e bem merecidas". De acordo com o autor, d. Pedro II, de maneira bastante imanente, utilizava-se de inteligentes artifícios para garantir seu poder; um expediente, "várias vezes repetido", era escolher, quando da sucessão ministerial, "um magnata qualquer não indicado pela opinião, apenas escolhido por seu capricho ou por intrigas cortesanescas. Com isso desorganizava os partidos em formação, desmentia todas as previsões, e o poder moderador dava mais uma volta à sua chave". ${ }^{303}$ Quem emerge dessas páginas, portanto, é um imperador que, se dono de certas virtudes, não era dos menos inteligentes e estrategistas. No entanto, nem sempre sabia lidar com tanta desenvoltura com as situações que se apresentavam; segundo Capistrano, "no começo do reinado, ele perpassava pelos candidatos como um passarinho sobre flores que mais lhe agradavam ao olfato ou à vista". Era algo que

\footnotetext{
${ }^{301}$ Capistrano de Abreu. "Fases do Segundo Império". Op. cit., pp. 78.

${ }^{302}$ Capistrano de Abreu. "Fases do Segundo Império". Op. cit., p. 80.

${ }^{303}$ Capistrano de Abreu. "Fases do Segundo Império". Op. cit., p. 79.
} 
exasperava os políticos; desejosos de encontrar meios de "limitar-lhe o arbítrio", "descobriram a cunha, nulidade no meio de dois homens de peso". Ou seja, a fim de evitar grande perda de poder de qualquer das partes, havia como que um elemento neutro; assim, "o imperador escolhia a cunha, com grande gáudio das galerias". No que diz respeito ao tema da cunha, Capistrano levanta uma questão pertinente e incômoda à memória de d. Pedro II: “essa suscetibilidade, este desforço impróprio das supremas responsabilidades serviam os interesses da pátria ou acautelavam os destinos da dinastia?"304

Com essa tônica ressabiada, o autor entra na análise da década de 1850, "a mais brilhante do império", período em que se fechou o "livro miserável do tráfico negreiro"; "ajudou-se a Argentina a libertar-se da tirania de Rosas"; "tratou-se de liquidar a onerosa herança dos limites, legada pelas metrópoles peninsulares"; "regularizam-se e amiudaram-se as comunicações por vapor com a Europa"; Mauá "rasgou muitas das faixas coloniais, começou a remodelar o Brasil moderno". ${ }^{305}$ Foi, também, o momento em que, a partir da ação de Honório Hermeto Carneiro Leão, organizou-se o gabinete que "tomou por mote a conciliação". De acordo com o autor, "a conciliação implicava abrandamento de paixões, renúncia a meios violentos, defesa contra o rotativismo ensaiado em São Cristóvão, crença na virtude saneadora de comícios”. Essa prática conciliatória deveria ser acompanhada por uma lei eleitoral, que garantiria "todas essas maravilhas, substituindo os círculos às províncias". No entanto, diante disso tudo, é difícil não ficar temeroso; Capistrano lança nova questão, essa ainda mais contundente: “serão compatíveis com a índole brasileira eleições honestas?” De forma habilidosa, traz à tona o momento atual, a época em que escreve seu texto, para pensar o passado:

Hoje a fraude começa pelo alistamento eleitoral, prossegue pelo depósito fosfórico do voto, quando não se prefere quebrá-la ou roubá-la pela apuração fraudulenta da urna, pelo viciamento de diplomas, pela entrega à comissão verificadora. A República trouxe uma novidade essencial: alguém que pode estar ou não no Catete superintende o reconhecimento de poderes, isto é, o direito ao subsídio e mais achegas: é o homem mais poderoso do Estado, é o Poder Moderador das instituições vigentes. ${ }^{306}$

Assim, ao introduzir o tema da Conciliação e a questão eleitoral, Capistrano encontra a brecha na qual fazer críticas à República; perceba-se que, ao fazer isso, não elabora uma visão positivada do Império, tal como fariam os aduladores de Sua

\footnotetext{
${ }^{304}$ Capistrano de Abreu. "Fases do Segundo Império". Op. cit., pp. 80-81.

${ }^{305}$ Capistrano de Abreu. "Fases do Segundo Império". Op. cit., p. 81.

${ }^{306}$ Capistrano de Abreu. "Fases do Segundo Império". Op. cit., pp. 81-82.
} 
Majestade. Tanto o é que, de forma um tanto abrupta, algo próprio da dinâmica deste texto breve e panorâmico, Capistrano muda de assunto e foca no imperador; nesta década de júbilo, que atingiria o ápice com a questão Christie, ia muito bem o monarca: "belo, sadio, augusto, ninguém lhe disputava a autoridade". Patrocinava obras de arte, teatro e literatura; "Varnhagen esforçadamente erigia sua ciclópea História Geral. O Instituto Histórico reunia os sábios da cidade e entre eles fazia figura de destaque $\mathrm{S}$. Majestade". Além do mais, angariava, com sua integridade, a confiança do povo, "isto é, a massa dos não politiqueiros de profissão"; além disso, "a maior parte de seu subsídio - oitocentos contos anuais - ia-se em esmolas à pobreza envergonhada, em subvenções a estudantes pobres e artistas incipientes". Não tinha favoritos e, dessa maneira, favorecia inúmeras vocações, talentos que, sem ele, acabariam restando na obscuridade. De acordo com Capistrano, em uma apreciação interessante e que revela a desconfiança marcante do imperador para com o seu entorno, d. Pedro II não tinha favoritos "porque não admitia homens necessários". ${ }^{307} \mathrm{O}$ único necessário, pessoa imprescindível ao Império, era ele próprio, mais ninguém.

Nova guinada nessas "fases do segundo império" ocorreria com a Guerra do Paraguai; antes de qualquer coisa, salta aos olhos a forma como Capistrano dá certo sentido pessoal ao início do conflito. Assim, segundo ele, o aprisionamento do vapor mercante brasileiro e a invasão do Mato Grosso e Rio Grande do Sul, estopins do conflito, "só a psiquiatria pode oferecer explicação"; o imperador, por sua vez, "recebeu em cheio a afronta, nasceu-lhe um ódio a López que nada pode arrefecer; nem mesmo as condições, algumas bem humilhantes, do tratado da Tríplice Aliança, o fizeram hesitar". Está-se longe, neste momento, da figura de um monarca comedido; o interessante é perceber como o autor não fornece maiores explicações para o conflito, nada que vai além dessas questões inexplicáveis até mesmo para a psiquiatria. A guerra, assim, seguia terrível por conta de rusgas pessoais; o entusiasmo inicial já se perdera, mas o conflito não diminuía a marcha; por conta disso, "o recrutamento revestiu as formas mais bárbaras; foram agraciados os ricaços que libertavam escravos e lhes sentavam praça, até criminosos foram admitidos". Começava a se nuançar uma crise, cujo emblema maior foi a demissão de Zacarias e a dissolução da Câmara; dessa vez, no entanto, as coisas não eram como antes; a cidade crescera, "não tardariam os bondes em

\footnotetext{
${ }^{307}$ Capistrano de Abreu. "Fases do Segundo Império". Op. cit., pp. 82-83.
} 
atirá-la por aí afora, baralhando em democracia barata todas as pretensões sociais"; a imprensa, outro fator a ser levado em conta,

neutra e próspera, amamentada por testas de ferro, não conhecia barreiras. [...] Surgiam caricaturas e o lápis do litógrafo desafiava o lápis fatídico. Sentia-se a necessidade do desrespeito, da bombochata. Esvaía-se o nimbo imperial e o Imperador era puxado para o fandango.

Nenhum autor analisado, neste capítulo, elaborou de forma tão profunda, levando em conta até a disposição urbana carioca, o início da crise do Segundo Reinado; neste texto, não se trata de uma crise ministerial, e sim de uma efetiva crise social. Não havia mais, diante desse novo cenário, o apoio fácil, nem o encantamento ou a admiração com a figura imperial. O monarca, por sua vez, além de insistir na guerra, que terminaria somente com o "extermínio de López e no quase extermínio de seu povo", não percebeu como as coisas mudavam, "da diferença não deu fé". Pelo contrário, agora, "absorvia-o novo divertimento intelectual", qual seja, o estudo, muito incentivado por Gobineau, das línguas orientais. ${ }^{308} \mathrm{Ou}$ seja, aparece, aqui, um d. Pedro descompassado de seu contexto, um tanto alienado dos problemas de seu império. Quando não bem articulada à prática, esse é o risco da transcendência pautada no saber, da política apolítica. Aparece, também, uma abordagem da história que, conforme expresso na epígrafe desta seção, busca temas profundos, não eventos pontuais, que se desenrolam ao sabor dos governantes.

Nesse momento, além do mais, algo que ficava evidente após a Guerra de Secessão nos Estados Unidos, a questão da escravatura aparecia no horizonte como fator premente - agora, sim, um tema muito pertinente. Na visão de Capistrano, ao invés de, do alto de sua experiência, resolver a questão e deixar o governo provisório, já "livre desta monstruosidade", nas mãos de sua filha, preferiu rumar para a Europa, "em parte por motivo da saúde da imperatriz, em parte para conhecer e tornar-se conhecido no outro hemisfério", legando o problema à inexperiente princesa. No Velho Mundo, longe dos dilemas da questão escrava, angariou simpatias, mas não sem certos imprevistos; como diz Capistrano, "obrigado a convivências que não conhecia, ele que olhava sempre os outros de cima para baixo e para a lei aonde quer que pisava, cometeu não poucas descaídas". Na imprensa brasileira, tais "descaídas" sempre apareciam ressaltadas naquilo que tinham de ridículo e caricato; assim, "a imprensa indígena tudo deformava”. É interessante notar como, desde o tema da Guerra do Paraguai, Capistrano

\footnotetext{
${ }^{308}$ Capistrano de Abreu. "Fases do Segundo Império". Op. cit., pp. 84-85.
} 
muda sua maneira de tratar com o imperador, torna-se mais duro e, até mesmo, irônico; isso, no entanto, não significa que passava a ser um crítico sem parâmetros, tal como se pode ver nessa condenação da "imprensa indígena". Parece haver sempre um equilíbrio na sua interpretação; não está ocupado em julgar a pessoa do monarca, nem em exaltála; como dito na abertura dessa seção, no escopo de sua produção, as questões pessoais estavam longe de serem preocupações suas. A outra viagem do imperador, desta feita para os Estados Unidos, também causaria algum embaraço à princesa, pois, após a partida do pai, ela anistiou os bispos de Olinda e Pará, o que deu início a "uma campanha odienta: era carola, lavava as igrejas de Petrópolis, movia-se aos acenos dos padres, Joana a louca, Maria primeira, etc." Com isso, muito por conta de certa irresponsabilidade do imperador itinerante, ia ficando em dúvida a existência de um possível terceiro reinado, ainda mais quando se leva em conta os ressentimentos para com a princesa regente, "originados da lei do ventre livre". Na percepção de Capistrano, o melhor que se podia entender do caso dos bispos foi que, "com o travo episcopal ganhou a República que separou a igreja do estado, como nem um outro país católico jamais o logrou". Da abolição, por sua vez, podia-se entendê-la como o reparo de dois dos "maiores erros causados pelas dinastias de ultramar", quais sejam, "um país uno de capitanias separadas" e uma economia que parecia "só poder subsistir" com escravos. ${ }^{309}$ A lei Áurea, de forma incompleta, é certo, unificava o país pela questão da mão de obra e cortava as raízes de uma herança colonial, a mais danosa de todas.

D. Pedro II, quando da volta de sua última viagem à Europa, na qual sofrera com problemas de saúde, agonizando em Milão nos momentos mais acesos do 13 de maio, é recebido, reflexo da abolição, com certo entusiasmo. Não passavam, esse calor momentâneo e a acolhida positiva, na visão de Capistrano, de "mera fantasmagoria". Transcendência e imanência se desligavam uma da outra; o imperador, já há algum tempo, "não conciliava mais respeito". Não havia mais admiração pela sua figura, tornava-se um tanto anacrônica, motivo de chacota:

despertavam chacota o manto e os papos de tucano com que se dirigia, de voz pouco imperatória, aos augustos e digníssimos senhores representantes da nação, a canja que preferia na sua sobriedade invencível, os cochilos que dava nos atos públicos, as conferências da Glória, as palestras literárias do Pedro II, as sessões do Instituto Histórico. A moléstia não permitia longos anos de vida ${ }^{310}$.

\footnotetext{
${ }^{309}$ Capistrano de Abreu. "Fases do Segundo Império". Op. cit., pp. 85-86.

${ }^{310}$ Capistrano de Abreu. "Fases do Segundo Império". Op. cit., pp. 86-87.
} 
A partir disso, a monarquia vai caindo, quase como um castelo de cartas. Capistrano lista três estágios na "catástrofe final": o assassinato, cometido "às barbas da polícia”, de Apulcro de Castro, redator do periódico Corsário, fato que mostrava claramente o caráter dos militares e revelava como a "monarquia contava seus dias pela paciência da guarnição"; as desavenças com os militares; e a confusão que cercou o Quinze de novembro, quando o que era para ser uma mudança de gabinete se transformou em uma mudança de regime. De acordo com o autor, não estava decidida previamente a alteração na forma de governo; se não foi assim, como explicar, então, "que esperassem as sombras da noite para proclamá-la sem solenidade, por meio de um boletim só divulgado no dia seguinte?". Diz ainda que, para explicar a hesitação de Deodoro e a sua decisão final "tem-se recorrido a diversas histórias sem necessidade"; não havia nisso nada de grande mistério, afinal, "unido o exército, submetida senão jubilosa a população da cidade, preso o ministério, cercado o imperador, só restava enterrar os mortos, e tratar dos vivos. Não havia que escolher nem hesitar". Assim, foi proclamada a República e em 17 de novembro, "o cruzador Parnaíba levava o imperador e toda a sua família à ilha Grande, donde o Alagoas o transportou para a Europa". 311

Esse final, pontuado por certa melancolia, deixa claro o teor deste texto, breve e panorâmico, porém propositivo. Capistrano, ao longo de poucas páginas, se embrenha por uma história factual, ligada a nomes e detalhes; esse, contudo, apesar de um caminho necessário, não parece ser o essencial. Por conta disso, talvez, afirme que no final do Império não havia motivos para escolher ou hesitar; a partir do momento em que a crise se tornara social, condenando a aceitação da monarquia, e que mudara a questão da mão de obra, qualquer intriga de quartel ou palácio seria apenas a gota d'água. O fundamental já estava dado, era um caminho sem volta. Isso confirma a opinião de José Honório Rodrigues (1913-1987), que diz o seguinte acerca de Capistrano: para ele, "a história não é somente uma questão de fato; ela exige imaginação que penetre o motivo da ação, que sinta a emoção já sentida, que viva o orgulho ou a humilhação já provados"; assim, o que importava "não era só a coisa, era o espírito da coisa". ${ }^{312} \mathrm{Na}$ queda do Império, o espírito da coisa não era o golpe, e sim a

\footnotetext{
${ }^{311}$ Capistrano de Abreu. "Fases do Segundo Império". Op. cit., pp. 87-88.

312 Ainda segundo José Honório Rodrigues, comentando a obra de Capistrano de Abreu: "o mundo histórico é um mundo de símbolos e o historiador não pode determinar e compreender as coisas e os acontecimentos sem proceder antes a uma análise destes mesmos símbolos. O conhecimento dos fatos em
} 
crise que se nuançara a partir de transformações socioeconômicas. A partir disso, é possível compreender porque, mesmo não tecendo maiores críticas ao monarca, o artigo de Capistrano de Abreu tenha sido incluído entre as flores com espinhos; d. Pedro II, um pouco alienado, parece sempre gravitar distante dos pontos fundamentais, mas jamais deixa de fazer política, essa é a ideia que se pode tirar do texto. Dos Capítulos de história colonial já fícava claro que era preciso focar na formação do povo e na conquista do sertão, naquilo que era fundamental e possuía um sentido, por assim dizer, estrutural; nessas "Fases do Segundo Império" percebe-se que, no momento em que temas fundamentais foram tratados, d. Pedro II não se sustentou. A monarquia caiu, mesmo com todas as hesitações. O espírito estava dado, e fora com ele que o monarca não soubera tratar. Faltava somente a coisa. Esses são espinhos, portanto, de outro tipo, mais profundos; espinhos de plantas do sertão.

ordem cronológica dá-nos apenas um esqueleto da história, mas não nos dá a compreensão da vida humana. $\mathrm{O}$ ato último e decisivo cabe à imaginação produtiva, à adivinhação que busca nos documentos sua justificativa, como dizia o próprio Capistrano". José Honório Rodrigues. "Explicação”. In: Capistrano de Abreu. Capítulos de história colonial (1500-1800). Op. cit., p. 5 e p. 20. 


\title{
4. 2. 2. Medeiros e Albuquerque: muito além de uma impostura literária
}

\author{
Alma podre de rei, que, não podendo \\ ganhar amigos pelo teu heroísmo, \\ as outras almas ias corrompendo \\ pela baixeza, pelo servilismo, \\ por tudo quanto a consciência abate, \\ - alma podre de rei, procura em volta \\ do teu ruído trono desabado \\ que amigo te ficou, onde a revolta \\ possa encontrar indômito soldado. \\ De tanta infâmia e tanta covardia - \\ só covardia e infâmia, eis o que resta! \\ A matilha, a teu mando, que investia \\ contra nós, - nesta hora tão funesta, \\ volta-se contra teu poder passado! \\ Os vendidos da fé republicana, \\ os desertores de ontem - desertores, \\ hoje volta de teu para o nosso lado! \\ Vai! Que as ondas te levem mansamente... \\ Por esse mar, que vais singrar agora, \\ - arrancado a um cadáver ainda quente - \\ anos há que partiu, oceano a fora, \\ o coração do heroico Ratcliff. \\ A mesma vaga que, ao levá-lo, entoava \\ do livre mar eterno o canto, \\ como o não redirá, sublime e brava, \\ ao ver que passa no seu largo manto, \\ da monarquia o lutuoso esquife!
}

Medeiros e Albuquerque, no poema 17 de novembro de 1889 (fragmento)

As páginas do prefácio às Poesias completas de D. Pedro II não passam de vinte; contudo, apesar de poucas, transbordam, todas elas, uma pungente e afiada indignação. O curto texto é perpassado de uma necessidade de denúncia e de combate à mitificação. Quem assina o texto é um sujeito de nome grande, José Joaquim de Campos da Costa de Medeiros e Albuquerque, ou, como comumente era conhecido, Medeiros e Albuquerque (1867-1934). Natural do Recife, o escritor realizou seus primeiros estudos em casa e, depois, no Colégio Pedro II. Entre 1880 e 1884, permaneceu na Europa, onde realizaria estudos em Lisboa. De volta ao Brasil, fez o curso de História Natural com Emílio Goeldi e foi aluno particular de Silvio Romero, de quem, possivelmente, aprendera a arte de ser um polemista. Participou do movimento republicano e, quando da proclamação do novo regime, ocupou cargos públicos importantes, como os de ministro do interior e vice-diretor do Ginásio Nacional. Ao 
longo de sua vida, além de ter trabalhado no funcionalismo público e exercido mandato político como deputado federal, também foi jornalista e professor de diversas e importantes instituições de ensino, tal como a Escola de Belas Artes, na qual passou a lecionar a partir de 1890. Página das mais salientes de sua biografia, ele foi um dos criadores da Academia Brasileira de Letras, tendo fundado a cadeira de número 22. No que diz respeito à sua produção literária, escreveu contos, romances, teatro e ensaios; destacam-se, entretanto, as obras poéticas, notadamente aquelas marcadas por características estéticas simbolistas e que lhe valeram fama. Uma informação importante, talvez a que lhe garanta maior notoriedade, e a que permite entender o teor do texto a ser analisado: Medeiros e Albuquerque é o autor do hino da República. ${ }^{313}$

O prefácio em questão, apesar de ter sido publicado anteriormente, na forma de um estudo sobre a poética do imperador, ganhou maior audiência ao ser inserido como introdução, na edição organizada pelo próprio Medeiros e Albuquerque, às poesias completas de d. Pedro II. Tal edição, lançada em 1932, a crer no organizador, teve boa parte de seus poemas pesquisados e copiados de livros pertencentes à biblioteca particular de Joaquim Nabuco, seu colega de fundação da Academia de Letras, falecido anos antes, em 1910. Dentre as Poesias completas de d. Pedro II, constam versos de autoria do monarca, inclusos os controversos Sonetos do Exílio, além de traduções de poemas escritos por Victor Hugo, François Coppé, Félix Anvers, Jean Richepin, Sully Prudhomme, Lecont de L’Isle, Longfellow, Dante.

O curioso é que, em uma verdadeira inversão de fatores, o prefácio se trata de uma completa detração das poesias que foram compiladas e estão sendo introduzidas ao leitor; mais do que as poesias em si, é uma desqualificação quase que absoluta do autor delas. O imperador que surge dessas páginas, muito distante das imagens mais idealizadas, é um sujeito pouco confiável, inábil e insincero; isso, note-se, logo quando se aborda um de seus aspectos mais cultuados, a sua verve literária e cultural. O que quer dizer que arranjo é tomado completamente pelo lado do risco; assim, findo o trânsito virtuoso entre transcendência e imanência, uma e outra passam a se enfraquecer mutuamente. O cerne das críticas vão ser os Sonetos do exílio, supostamente escritos pelo imperador ao longo dos dois anos em que viveu após ter sido deposto. Esses Sonetos, originalmente, foram publicados em Paris, no ano de 1898, em um pequeno

\footnotetext{
313 Todas as informações biográficas acerca de Medeiros e Albuquerque foram retiradas do site da Academia Brasileira de Letras (www.academia.org.br).
} 
folheto de 28 páginas, por iniciativa dos herdeiros de d. Pedro II. Desde o momento em que vieram à tona, despertaram certo interesse da crítica pelas qualidades de alguns versos e pelo teor sentimental do conjunto. De acordo com o autor, contudo, e conforme diz logo no início do prefácio, não há nisso motivos para louvar o imperador, pois os sonetos "são indiscutivelmente apócrifos: uma impostura literária. Para ter certeza disso, basta ler as primeiras poesias que se acham nesta obra [Poesias completas]. O contraste é tão eloquente que dispensa qualquer demonstração". O tom da crítica já está dado: apesar de estar especulando sobre os fatos, a própria evidência dos versos não abre margem para dúvidas; era uma inverdade atribuir tais poemas ao seu suposto autor. O que pode parecer algo mesquinho, arranjar treta por conta de algumas estrofes suspeitas do monarca falecido, ganha vultos mais profundos, principalmente quando se pensa ser possível estabelecer alguns paralelos e comparações entre a atividade de versejador e a posição política ocupada pelo suposto poeta. Levando isso em conta, perceba-se a sutileza do seguinte comentário: "positivamente, o homem que durante 42 anos fez versos no gênero dos da primeira parte do volume que o leitor tem em mãos, não pode ser autor dos sonetos da segunda parte." ${ }^{\text {,14 }}$ A referência aos 42 anos de versos fracos e insossos dá densidade temporal à impostura, à fraude cometida pelo monarca deposto; pode-se perceber, desde o início, que o texto vai avançar sobre temas que vão além do literário, que a questão poética pode ser um meio para se chegar a outros fins.

A princípio, porém, o objetivo imediato é desqualificar d. Pedro II enquanto poeta, evidenciar sua incapacidade literária e, acima de tudo, sua mediocridade. Assim, é preciso continuar a desvendar a fraude: "ora, admite-se perfeitamente que um poeta medíocre tenha uma grande inspiração e faça subitamente uma composição de valor. A história literária registra vários fatos dessa natureza". Nesses casos, porém, os "poetas sabiam fazer versos. As suas outras composições eram medíocres, mas medíocres pelos assuntos. A técnica não se podia dizer muito ruim: o mal estava na substância". No caso do imperador, entretanto, não havia desculpa, nenhum menor indício de que ele poderia ser, bem lá no fundo, um versejador em potencial, alguém que dominasse o ofício apesar de não ter a inspiração necessária para realizar grandes obras. De acordo com o prefaciador, o monarca "sempre foi (podem vê-lo) integralmente péssimo: deficiência de ideias, imperfeição da técnica”. Era impossível aceitar que os sonetos em questão

\footnotetext{
314 “Prefácio". In: D. Pedro II. Poesias completas de d. Pedro II. Prefácio de Medeiros e Albuquerque. Rio de Janeiro: Editora Guanabara, 1932, p. 6.
} 
fossem da autoria de d. Pedro II; como ele diz, de maneira bastante clara e de forma a não deixar margens: "toda uma vida de versos ruins, até os 64 anos, em que não se produziu nada que se possa, mesmo com grande benevolência, chamar, ao menos, sofrível! O que não é péssimo é ultrapéssimo". 315

Dessas duras palavras, é possível pensar que a indignação de Medeiros e Albuquerque, dentre outros fatores, se devia ao desrespeito do monarca com a própria arte poética; ao cometer tal impostura, era como se o imperador tivesse feito pouco caso de tudo o que envolve o ofício de versejar, do qual o autor participava. A técnica, a sensibilidade, a inspiração, a beleza, o sentimento, a estética, e tudo o mais que se quiser incluir, eram como que deturpados pela mentira; para um escritor e poeta, membro fundador da Academia de Letras, isso era ofensa das grandes, um descaso inaceitável. Daí porque o mais importante não era saber quem fora, verdadeiramente, o autor dos sonetos - "é talvez inútil esperar que o mistério seja esclarecido. Quando se diga um nome qualquer, imediatamente aparecerão contestações enérgicas". O fundamental é perceber quais eram os objetivos dessa falsificação; seria, talvez, uma forma de engrandecer a imagem do monarca. O prefaciador coloca essa questão, para depois dizer: "se aquele que fez os versos - fê-los principalmente para aumentar o mérito do imperador, não virá revelar o que se pode chamar a sua piedosa impostura, inspirada em nobres motivos". Toca-se, aqui, uma questão interessante, porque demonstra, a partir de uma crítica ferrenha, como a cultura poderia ser usada enquanto meio de legitimação do imperador; afinal, um rei que cultua as musas e, ele mesmo, arranha seus versos, não poderia ser tão ruim assim. No mínimo, já era melhor que qualquer outro culturalmente menos versado. Haveria de existir, portanto, algum valor em figura tão peculiar. A questão do uso político e memorialístico dos sonetos fica evidente quando Medeiros e Albuquerque, provocativamente, diz que "como essas produções atribuídas ao monarca foram aplaudidas - e deviam realmente sê-lo, porque são dignas disso -, a família imperial, de que alguns membros, a princípio tinham negado a autoria dos sonetos do exílio, acabaram por calar-se, aceitando-a". ${ }^{316}$ E isso quer dizer que, em tudo o que cerca esses sonetos, há uma sombra de fraude; desde a autoria até os interesses que os envolvem. E, por que não, uma fraude no sentimento do exilado, posto que, quem

\footnotetext{
${ }^{315}$ Medeiros e Albuquerque. "Prefácio". Op. cit., pp. 6-8.

${ }^{316}$ Medeiros e Albuquerque. "Prefácio". Op. cit., p. 9.
} 
comete uma inverdade dessas, não sofria realmente com o afastamento da terra natal, não podia sentir falta de seu povo.

Da mesma forma que fala dos sonetos, encarando-os como fraudulentos, Medeiros e Albuquerque, a fim de minar toda a transcendência do rei filósofo, trata de outros aspectos da tão comentada cultura do monarca. Nesse ponto, aborda um episódio recorrente: o encontro de sua majestade com o famoso escritor Victor Hugo. Segundo o prefaciador, muita gente, de forma equivocada, fala maravilhas acerca da suposta admiração do escritor romântico pelo monarca; seria uma indiscutível prova do valor deste rei exemplar, capaz de ser recebido pelo mais republicano dos poetas. Isso, no entanto, seria uma lenda, um mito cunhado e alimentado pelos aduladores de d. Pedro II. Mais que isso, o próprio Victor Hugo era, em parte, responsável pela confusão; afinal, como diz Medeiros e Albuquerque, não é segredo para ninguém que ele "elogiava, a torto e a direito, todos os que lhe rendiam qualquer homenagem". Recebia, todo tempo, uma infinidade de obras que prometia ler, mas que, em realidade, nem chegava a tocar; mandava parabéns aos aspirantes a escritor que, efetivamente, nada de bom produziam. Com nítido espírito provocador, o prefaciador parte para o anedótico, a fim de sacramentar o que quer dizer: "ficou célebre um cocheiro de fiacre que se tornou maluco graças a um elogio de Victor Hugo. Chegou a candidatar-se à Academia francesa". Emerge, dessas palavras, a imagem de um rei caricato que, metido a fazer versos, não se diferenciava de um reles cocheiro de fiacre; se o primeiro queria ser reconhecido pelos sábios de todo o mundo, o segundo queria ir para a Academia francesa. Que grande diferença existiria entre eles? Além do mais, diante disso tudo, é possível "imaginar-se como o velho poeta, que até endeusava cocheiros, ficaria vaidoso com a amizade de um imperador autêntico, que ia a sua casa e dizia que a verdadeira majestade ali era a dele, Victor Hugo". ${ }^{317}$ É uma relação de vaidades, na qual todos acabam, levando em conta as proporções, se igualando em seus sonhos mais patéticos, seja o cocheiro, o rei ou o poeta romântico. Nenhum é mais exemplar que o outro.

O teor acusatório de Medeiros e Albuquerque, após estender-se sobre a incapacidade poética do imperador e a ilusão de seus sonhos de cultura, o que certamente atingia em cheio a imagem positiva que dele elaboravam os aduladores, vai ficando cada vez mais afiado e amplo, a ponto de comentar acerca das "tendências charlatanescas" do monarca, o que, maior parte das vezes, "importava em mentira e

\footnotetext{
${ }^{317}$ Medeiros e Albuquerque. "Prefácio". Op. cit., p. 11.
} 
tolice" ${ }^{, 318}$. O tom, assim, vai subindo em escala progressiva; do detalhe para o geral, $d a$ arte poética para a arte política. Outra coisa: percebe-se, nessa progressão, que os ataques ao imperador queriam repercutir, de forma mais bem acabada, sobre os "louvinhadeiros", tanto os de ontem quanto os de hoje. Para cumprir seu intento, em uma prática bastante comum, Medeiros e Albuquerque recorre, muitas vezes, ao episódico e corriqueiro para fazer seus comentários. Assim, surge, por exemplo, o tema do domínio que o imperador tinha sobre diversas línguas, a sua vertente de poliglota; no caso aqui tratado, mais exatamente o seu conhecimento do tupi: "os louvinhadeiros de d. Pedro II proclamavam por toda a parte que ele falava admiravelmente bem as línguas de todos os selvagens do Brasil”. Note-se que não é sem motivo que o foco recai sobre as línguas dos "selvagens do Brasil”, pois que melhor exemplo de ilustração, exotismo e espírito nacional do que este? No entanto, tudo vai redundar em nova impostura, na corrosão promovida pelo patético da anedota: “ora, aconteceu um belo dia que se aprisionaram alguns e vieram até o nosso museu nacional. D. Pedro para lá se dirigiu e... falou-lhes. Nenhum o entendeu... com esse fiasco, se divertiram os jornais da época". É uma situação ridícula, caso nítido de fraude. Para criar o efeito no texto, perceba-se o uso das reticências, que deixam vislumbrar o dramatismo da situação; é possível imaginar o constrangimento dos aduladores, que sentiam, a cada ponto dessas reticências, cair o véu da sabedoria imperial. Mas não para por aí; diante dos fatos, sustentado pelo gracejo das anedotas, Medeiros e Albuquerque sente-se livre para especular e lançar questões ainda mais amplas. De onde vinha, afinal, todo esse conhecimento do monarca, "quando o imperador poderia ter adquirido a sua encoroada ciência", se "ele era ainda um rapazola quando, sôfrego do poder, apressou a declaração da maioridade e começou a reinar"? No momento em que subiu ao poder - sôfrego de poder, note-se bem -, "os seus conhecimentos não iam além dos cursos preparatórios". Evidentemente, a pergunta fica sem uma resposta conclusiva, pois a intenção é, antes de qualquer coisa, fomentar a dúvida, lançar incômodos, mostrar quão abusivas podiam ser as ilusões, quão desmedidos os elogios louvinhadeiros. O certo, mesmo, é que o monarca, ele próprio, tinha "a mania de passar por sábio. Mania incontestavelmente mais inocente que se ele tivesse querido passar por valentão ou qualquer coisa análoga...." ${ }^{319}$ Novas insinuações, novas reticências, novos ridículos.

\footnotetext{
${ }^{318}$ Medeiros e Albuquerque. "Prefácio". Op. cit., pp. 13-14.

${ }^{319}$ Medeiros e Albuquerque. "Prefácio". Op. cit., p. 11.
} 
Para Medeiros e Albuquerque, portanto - e não se esqueça que se trata, nada mais nada menos, do prefácio das Poesias completas do imperador -, não há meios de louvar uma reputação inexistente. Nessa linha de pensamento, retomando os ataques sob outra perspectiva, os títulos concedidos a d. Pedro II por instituições científicas de todo mundo, sempre tão comentados positivamente, nada representavam, a não ser honrarias dedicadas a chefes de Estado. No caso da Academia de Ciências de Paris, junto à qual a diplomacia brasileira teria se mobilizado para garantir o título ao monarca, o caso foi cômico. Era preciso, diante da obrigação de incluí-lo nas fileiras da Academia, encontrar uma especialidade na qual encaixá-lo. Segundo o autor, depois de muito matutar, "um homem de imaginação descobriu: d. Pedro foi feito sócio correspondente da seção de geografia”. Situação esdrúxula, forçada pela diplomacia e pelas aparências. No decorrer da crítica, sente-se que Medeiros e Albuquerque, talvez, tivesse conhecimento dos reproches que Vicente Licínio Cardoso, no ano do centenário, fizera à Sua Majestade: “os acadêmicos franceses não tiveram, de certo, noção exata de como essa escolha era intensamente cômica, atendendo a que d. Pedro, embora tendo tido um longuíssimo reinado, nem ao menos fizera a descoberta geográfica do seu próprio país, do qual desconhecia a maior parte" ${ }^{, 320}$.

Parece haver, assim, um trajeto comum a alguns críticos: partir do mínimo e do que é supostamente inquestionável, tal como a cultura elevada e os reconhecidos conhecimentos geográficos do monarca, para, a partir da deturpação desses mesmos fatores, subir de nível, desvendar fraudes e evidenciar a falta de ação, o marasmo do Segundo Reinado. Tudo importa, então, nessa figura; não há escape, qualquer detalhe já é suficiente para uma observação negativa, para um julgamento. Difícil perdoar suas faltas. Tais críticas, ressalta-se, não são arbitrárias, pois focam, sobretudo, aspectos políticos, revelam o arranjo pelo seu lado do risco; dessa forma, o que antes era força para o monarca, agora, torna-se prejudicial. Sem conhecer seu país, “esse homem bom, se assim se pode dizer, a quem o povo chamava 'o banana', viajou, foi à Europa, foi aos Estados Unidos, mas não foi... ao Brasil" (novamente, o recurso das reticências). Era o cúmulo do descaso: rodara boa parte do globo, fora ao estrangeiro, onde conhecera sábios e adentrara em escolas e academias; no entanto, nada sabia de seu vasto Império, das carências e urgências, dos investimentos cabíveis e necessários. Uma cultura vazia; um sinal, então, de uma política vazia. Não tinha curiosidade sobre questões práticas;

\footnotetext{
${ }^{320}$ Medeiros e Albuquerque. "Prefácio". Op. cit., p. 16.
} 
um interesse que, por outro lado, "nunca the faltou para durante longas horas de cada dia ler cartas anônimas e anotá-las com o seu lápis, a que então se chamava 'o lápis fatídico". ${ }^{321}$. Aqui surge o detalhe em toda a sua força; algo quase insignificante quanto o "lápis fatídico" - que aparece, para o bem ou para o mal, nos comentários de muitos intérpretes -, se transforma em motivo de críticas, quase paródias. O objeto, mínimo que seja, parece ser tão fundamental quanto qualquer outra coisa, é um feixe de significados e sentidos, do qual se pode retirar aquilo que mais interessa ao intento almejado. Está, então, evidente um risco dos mitos e das suas representações: um lápis, muitas vezes, é mais comentado do que um reinado de quase cinco décadas. O que servira para elogiar - afinal de contas, as anotações com o "lápis fatídico" podiam ser sinal de argúcia e dedicação extremas -, subitamente, se converte em piada, pilheria e corrosão. A subversão pode estar contida, assim, nos poucos centímetros de um lápis; não um lápis qualquer, mas aquele que se relaciona com o mito, que se inscreve em um conjunto amplo de significados. Novamente, trata-se de um jogo de capturas, no qual as possibilidades são múltiplas.

Medeiros e Albuquerque, dentro dessa lógica, trata de temas complexos da vida pública seguindo pelo mesmo viés anedótico do texto. É assim que vai tocar em um dos assuntos mais comentados, positivamente, acerca do imperador: "todas as famas de d. Pedro II foram exageradas, deformadas ou inventadas. Houve, por exemplo, quem falasse na 'ditadura da honestidade' que ele exerceu". A honestidade do monarca era um tema fechado, estava acima de qualquer suspeita; nosso autor, não duvida disso, chega a afirmar que, "de fato, foi um homem honesto, que abominava (era um bom traço) os desonestos". A grande questão é não tomar tudo de forma simples e superficial; é preciso entender o queria dizer a honestidade do monarca, como ela se dava. Nesse sentido, apesar da louvável honestidade, "tudo isso era feito maquinalmente" e de forma a beirar o ridículo. Para provar o que diz, Medeiros e Albuquerque retoma o caso das cartas anônimas - uma cena, aliás, digna de figurar nas páginas da novela As joias da coroa, de Raul Pompeia, quando de uma descrição dos hábitos políticos do Duque de Bragantina: "no fundo do seu palácio um dos seus grandes prazeres era receber cartas anônimas, acusando este ou aquele". O monarca, dessa maneira, "não resolveu nenhum grande problema nacional"; no entanto, “em compensação, podia dizer com segurança se um obscuro amanuense de uma repartição de ínfima classe em Mato Grosso ou Goiás

\footnotetext{
${ }^{321}$ Medeiros e Albuquerque. "Prefácio". Op. cit., p. 18.
} 
tinha ou não tinha uma amante! As cartas anônimas o informavam! Nessa vidinha mesquinha de velha alcoviteira, se passou o seu tempo". Em suma, quer-se falar de honestidade, mas perceba-se sobre que mesquinharia se arvorava essa tão propalada virtude; uma qualidade que, mesmo podendo ser louvada, não deixa de ser fácil e vazia de sentido. Não satisfeito, o autor lança ainda uma última constatação sobre o tema; questiona o efetivo valor de um sentimento de honestidade e uma prática idônea quando d. Pedro II tinha ao alcance tudo "o que precisava, como acontece aos monarcas, para os quais se votam grandes dotações: dotações para ele, para a mulher, para cada um dos filhos... honestidade com menor reconhecimento que a dos pobres". 322

No final do prefácio, Medeiro e Albuquerque, retomando mais uma historieta, marca uma posição clara, evidencia o lugar no qual se situa o seu estudo. Não só situa sua perspectiva, como tece críticas duras ao entendimento excessivamente positivado que se fazia, então, do monarca:

D. Pedro II é uma personalidade histórica, sujeita, portanto, pelos séculos adiante, a quaisquer críticas. É um direito permanente; que todos podem exercer. Não se trata de respeito ou desrespeito ao seu nome. Trata-se de firmar a verdade sobre a sua figura, debaixo de um dos aspectos que mais o interessavam [a poesia], e que por conseguinte não pode desinteressar à posterioridade. O secretário indiscreto de Anatole France contou que quando passou pelo Brasil, admirou-se de que por toda parte lhe falassem de d. Pedro II com uma veneração extrema, gabando-o como sábio, como artista, como administrador e como homem. E em certa ocasião o escritor francês não pôde deixar de perguntar por que, se ele era tudo isso, o tinham deposto. Pergunta perfeitamente lógica. Mas, deveras, o que se sabe é que ele não tinha nenhuma daquelas qualidades. E foi exatamente por isso, que se viu muito justamente deposto. Os aduladores excessivos de sua memória esquecem-se de que, para exaltá-lo, precisam deprimir o Brasil. ${ }^{323}$

Mais do que em qualquer outra parte de seu texto, aqui está evidente que o autor se insere em um debate. Tratando os oponentes por "aduladores excessivos", firma o seu lugar: o de um republicano que não aceita versões idealizadas do passado, que se recusa a deprimir o presente do Brasil em nome de um vulto fraudulento do passado. Para isso, se dispõe a derrubar mitos, negar supostas qualidades do monarca, fazer claros os motivos de sua deposição. A partir dessa postura, surge um fato interessante a ser levado em conta: um exemplo, dos mais excessivos, de adulador, como já comentado, era Carlos Magalhães de Azeredo (que, inclusive, usa história semelhante à de Anatole France em seu livro), um dos colegas de Medeiros e Albuquerque na

\footnotetext{
${ }^{322}$ Medeiros e Albuquerque. "Prefácio". Op. cit., p. 17.

${ }^{323}$ Medeiros e Albuquerque. "Prefácio". Op. cit., p. 20.
} 
fundação da Academia Brasileira de Letras; logo, é interessante notar como não havia, no cerne dessa instituição, um entendimento único no que diz respeito ao monarca. Aduladores e críticos conviviam lado a lado - lembre-se, ainda mais, que Pedro Calmon também será um imortal, só que a partir de 1936, quando Medeiros e Albuquerque já falecera; e que Rodrigo Octavio e Oliveira Lima, autores há pouco citados, foram os fundadores das cadeiras, respectivamente, de números 35 e 39. Azeredo transbordava admiração; Calmon, pouco depois, faria o mesmo; Octavio rememorava tranquilo; Medeiros e Albuquerque, ao organizar e prefaciar as Poesias completas, não se fizera de rogado em mostrar todo o seu repúdio a d. Pedro II. Dessa diversidade, pode-se constatar a variedade e o clima de incerteza que medrava na relação com a memória do monarca, a ponto de nem no bojo de uma instituição, tal como a Academia Brasileira de Letras - talvez, ela mesma um símbolo da difícil transição entre Império e República -, haver um consenso. Sobre a ABL, é importante notar que, antes de qualquer coisa, ela servia como um espaço no qual os escritores podiam sustentar sua legitimidade e garantir inserção profissional. Como diz Alessandra El Far,

esses literatos almejavam criar uma associação que fosse capaz de garantir os interesses de um grupo específico. Uma academia sob a égide da República poderia proporcionar aos futuros acadêmicos reconhecimento público, maiores oportunidades de publicação nos jornais e editoras, melhores remunerações e uma visibilidade social até então inexistente na nascente profissão das letras no país.

Por conta disso, além de dividir-se "em parnasianos, realistas e naturalistas", os acadêmicos, "no terreno da política, igualmente, tinham opiniões díspares. Enquanto alguns eram a favor da República, outros ainda sonhavam com a monarquia ou mesmo com a futura instauração de regimes socialistas no país". ${ }^{324}$ Ou seja, o tema da mudança de regime era candente e permanecerá semeando diferenças por um bom tempo, mesmo dentro de uma instituição voltada para fins profissionais. O monarca, portanto, era mote de acirrados debates, ainda mais quando se tocava em assunto tão cheio de meandros e detalhes, como era a sua verve de poeta.

Sobre o assunto, mais um episódio. Em 1975, o clube Piratininga, órgão social e recreativo sediado na cidade de São Paulo, fez publicar, como separata do número 79 da revista Paulistania, uma edição fac-similar dos Sonetos do exílio. No final da

\footnotetext{
${ }^{324}$ Alessandra El Far. A encenação da imortalidade. Op. cit., p. 34 e p. 65.
} 
introdução, de outubro de 1975 e assinada por Pedro Brasil Bandecchi, escritor e membro da Academia Paulista de Letras, constam as seguintes palavras:

A revista Paulistania, órgão oficial do Clube Piratininga, ao publicar o folheto, na íntegra, presta relevante serviço às letras históricas de nossa pátria, dada a raridade da edição, aparecida há 77 anos corridos. Tudo leva a crer ser esta sua segunda tiragem. De qualquer forma, segunda ou não, é obra dificilmente encontrada e seu aparecimento, neste ano do sesquicentenário do nosso segundo imperador, é oportuno e importante. ${ }^{325}$

Em 1975, assim, por ocasião das comemorações do sesquicentenário do imperador, uma nova edição de seus Sonetos do Exílio vinha à tona. No mesmo ano, como já lembrado, surgira renovada edição do livro de Pedro Calmon, dessa vez feita sob os auspícios dos militares e purgada de seus aspectos mais polêmicos. O tom laudatório das obras e comentários não deixa dúvidas de que o arranjo enfeixado no monarca continuara a existir e a agir. É de se imaginar o que, acerca disso tudo, teria dito o nosso Medeiros e Albuquerque, autor do hino à República e de um prefácio avassalador às Poesias completas de d. Pedro II.

\footnotetext{
${ }^{325}$ Esse exemplar fac-símile estava anexado no volume das Poesias completas de D. Pedro II, consultado na biblioteca da Academia Paulista de Letras; Pedro Brasil Bandecchi ocupou a cadeira número 38 dessa instituição.
} 


\section{2. 3. Carlos Sussekind de Mendonça: o julgamento do monarca e o combate ao saudosismo}

"O que se quis fazer se fez - opor à obra insidiosa e desonesta de achincalhe à República, mal embuçada nos protestos de uma fidelidade insincera e interesseira ao Passado, fatos, datas e algarismos que convençam depressa, logo à primeira vista, de que lado está a razão. De muito pouco valeria ao povo que as estatísticas fossem mais precisas e as citações mais longas. O que importa é possuir-se da convicção de que os Bons Tempos, com que enchem a boca os derrotistas, foram piores que os de hoje. E isso, quando não seja mais uma esperança, ainda é um consolo".

Carlos Sussekind de Mendonça, em Quem foi Pedro II: golpeando, de frente, o saudosismo

Da primeira à última palavra, da epígrafe ao derradeiro ponto final, o livro é, por assim dizer, uma efetiva batalha. Na obra do jurista e ensaísta Carlos Sussekind de Mendonça - autor que Roberto Ventura enquadra numa linha de polemistas que remonta a Sílvio Romero (1851-1914) e Araripe Júnior (1848-1911) ${ }^{326}$-, Quem foi Pedro II: golpeando, de frente, o saudosismo, publicada em 1929, tudo é motivo para críticas; nela, as várias facetas do imperador são expostas para, em sequência, serem demolidas naquilo que podiam apresentar de positivo. Não só as do imperador, como, e principalmente, a de seus defensores, dos sebastianistas e saudosistas, de seus retrógrados aduladores. De início, leia-se, antes de qualquer coisa e para não deixar dúvidas sobre o teor do livro, a própria epígrafe: “É bom que estes velhacos vejam que custa pouco reduzir a cacos um imperador". A frase, desafio lançado aos patifes da memória, é creditada ao escritor, ministro e imortal Lúcio de Mendonça (1854-1909), pai do autor, a quem o livro é dedicado - note-se um fato curioso: à semelhante ao que faria Heitor Lyra, cerca de uma década depois, só que por motivos completamente distintos, trata-se de um livro sobre d. Pedro II feito em homenagem a uma figura paterna. ${ }^{327} \mathrm{Na}$ dedicatória, Sussekind diz que o estímulo para realizar a obra foi, acima

\footnotetext{
${ }^{326}$ Roberto Ventura. Estilo Tropical: história cultural e polêmicas literárias no Brasil (1870-1914). São Paulo: Companhia das Letras, 1991, p. 80.

327 De acordo com a biografia disponível no site da Academia Brasileira de Letras (www.academia.org.br), Lucio de Mendonça estudou na Faculdade de Direito de São Paulo, tendo se formado em 1878; antes disso, por seu envolvimento em polêmicas contra os professores, ficou suspenso por dois anos, período que passou no Rio de Janeiro trabalhando na redação do jornal A República. Com a instauração do regime de 1889, exerceu importantes cargos na magistratura e na alta burocracia, até ser nomeado Ministro do Supremo Tribunal Federal, em 1895. Dali a pouco tempo, em 1897, participaria da criação da Academia Brasileira de Letras, sendo o fundador da cadeira de número 11. Alessandra El Far,
} 
de tudo, a saudade do pai, que falecera vinte anos antes, mas cujo alto exemplo, moral e intelectual, jamais fora esquecido. Sugestivamente, três anos pontuam e servem de moldura para a memória: 1889,1909 e 1929 . O que quer dizer, trocando em miúdos: a proclamação da República, a morte do pai e - exatamente no ano em que se completariam quarenta anos do Quinze de novembro - a publicação do livro. Nessa lógica - de vinte em vinte anos -, a esfera do pessoal está diretamente atrelada à do nacional; são duas instâncias que se cruzam e complementam, não existindo uma sem a outra. A efeméride que motiva a publicação do livro, aquela que justifica a revisão do passado e o balanço crítico, é a celebração de mais um lustro do regime republicano; no entanto, isso só adquire sentido pleno por conta de outro aniversário que se completa: o da morte do pai republicano. Portanto, a partir de um modelo de conduta, o paterno, quer-se desmantelar, "reduzir a cacos", o outro, o do imperador. Dessa maneira, lembrança e esquecimento, em uma verdadeira dialética da memória, estão na origem desse estudo tão combativo e propositivo.

Seguindo adiante, é preciso se deter, agora, na introdução do livro. O texto é assinado pelo jornalista Pedro Motta Lima (1897-1966), membro do Partido Comunista Brasileiro e diretor do jornal $A$ Esquerda, órgão no qual foram publicados, de maneira seriada, os artigos que compõem o livro. Nessa apreciação introdutória, o contexto e a tônica do livro começam a ser nuançados; trata-se de uma reunião dos "artigos que Carlos Sussekind de Mendonça organizou para a 'Semana de Pedro II', com que $A$ Esquerda resolveu, em dezembro de 1927, golpear, de frente, o 'saudosismo"”. Contadas quase quatro décadas da proclamação da República, e face à crise do regime republicano, era preciso fazer um balanço, repensar a figura imperial para lançar luz ao presente; somente assim seria possível combater o saudosismo que ainda medrava na vida política nacional. Segundo Motta Lima, é fundamental ter consciência de que, para

em seu estudo sobre a ABL, aponta Lúcio de Mendonça como um dos principais articuladores da ideia de fundar uma instituição como essa no Brasil; em seu projeto inicial, propunha uma academia neutra e ligada ao regime republicano: "A academia seria, na concepção de Lúcio de Mendonça [em seu projeto, de novembro de 1896], um local neutro, onde seus integrantes não se deixariam levar pelas calorosas defesas do regime republicano ou monárquico. A discussão acadêmica situar-se-ia além de qualquer incompatibilidade política, e a maior prova dessa neutralidade seria eleger como membros homens da estatura de um Joaquim Nabuco, Taunay e Afonso Celso, que ainda defendiam a antiga monarquia, ao lado de declarados republicanos, como Olavo Bilac, Coelho Neto e o próprio Lúcio de Mendonça". Alessandra El Far. A encenação da imortalidade. Op. cit., p. 23. Lembre-se que a ABL foi fundada somente em 1897, como uma instituição privada. Segundo o crítico Alexandre Eulálio, Lucio de Mendonça escreveu alguns dos primeiros "contos rústicos da nossa literatura que valham por si mesmos se se quer, os nossos primeiros contos 'regionais"”. Alexandre Eulálio. "O último bom selvagem: "Luís da Serra' de Lucio de Mendonça”. In: Tempo reencontrado: ensaios sobre arte e literatura. Organização de Carlos Augusto Calil. São Paulo: Instituto Moreira Salles; Editora 34, 2012, p. 61. 
elaborar os textos, o que lhes dá insuspeita credibilidade, o autor foi imparcial na escolha das fontes; foi atrás tanto da "palavra de historiadores sem tendência acentuadamente antimonárquica", quanto das "confissões de uns tantos sebastianistas peróbicos". Contam-se, entre os seus "colaboradores" - conforme diz, de maneira irônica, o próprio Sussekind de Mendonça -, os seguintes nomes: Joaquim Nabuco, Tobias Barreto, Lúcio de Mendonça, Medeiros e Albuquerque, Afrânio Peixoto, Eusébio de Queirós, Nabuco de Araújo, Francisco Otaviano, Cotegipe, José de Alencar, J. M. de Macedo, dentre outros. É uma antologia de opiniões que vai se repetir no decorrer dos artigos; o interessante é perceber a diversidade dos ditos "colaboradores", o que dá ideia da maneira do autor construir sua argumentação, sua busca por opiniões diversas e, de forma a sempre fazer emergir uma opinião crítica ao monarca, a costura que realiza.

A partir dessa multiplicidade de opiniões - tanto "demolidores", quanto "amigos da corte" -, a coletânea de artigos escritos por Sussekind, retomando a introdução de Motta Lima, "mostra à geração atual que o melhor tipo de soberano dos últimos tempos era, afinal, uma exploradíssima 'blague'. Um lugar comum repetido pela má fé de alguns e pela ignorância de muitos". Ou seja, está-se falando, aqui, de uma desconstrução crítica, do combate a um mito do passado que deve ser feito para alertar as novas gerações da República acerca das necessidades de superar o passadismo. Mais que isso - e, agora, tocamos o ponto nodal -, são os "velhos derrotistas", admiradores e cultuadores de d. Pedro II, verdadeiros "reacionários do poder", os maiores responsáveis pelo "achincalhamento" da República; são eles "que a espada revolucionária de Floriano amedrontou mas não abateu convenientemente", eles os que "desafiam, de há muito, uma ação enérgica da parte dos que nascemos após 89 e não toleramos sem revolta a protelação na prática do governo do povo". ${ }^{328}$ A obra, portanto, mesmo tratando de uma figura do passado, que, supostamente, deveria estar morta e enterrada, na verdade, pretende alertar para a necessidade de uma ação presente.

Ainda no prefácio de Pedro Motta Lima, repercutem críticas às "facilidades dos republicanos", que, ao invés de provocar mudanças profundas e romper estruturas, "deixaram, nos mais altos cargos da direção do ensino, barões e condes apaixonadíssimos, e, não satisfeitos, acabaram entregando o governo aos conselheiros

\footnotetext{
${ }^{328}$ Pedro Motta Lima. "Introdução”. In: Carlos Sussekind de Mendonça. Quem foi Pedro II: golpeando, de frente, o saudosismo. Recife: Livraria Brandão, 1929, p. 11.
} 
do antigo regime". Um dos principais desses retrógrados seria o "escravocrata Rodrigues Alves, considerado 'o mais conservador dos conservadores' desde a monarquia...”. Lembre-se que Rodrigues Alves (1848-1919), já morto quando da publicação, fora figura de grande relevo na política brasileira; exercera os cargos de presidente da província de São Paulo, ministro da fazenda, deputado constituinte e senador, além de, entre 1902-1906, ter sido presidente da República; quando faleceu, iria tomar posse de seu segundo mandato na direção do país. Assim, "o mal de hoje é o dos homens formados sob as tortuosidades antigas, deformando o regime para adaptá-lo à monstruosidade de suas corcundas". É preciso, então, “que a nossa gente leia na história do Segundo Reinado a opressão, o embuste, o analfabetismo, as endemias, o cativeiro, a rotina - todo o atraso que nos distanciou quase um século da civilização americana”. Que haja desencanto com um passado entendido enquanto glorioso, que se "perca as ilusões, repila a mentira, crendo nas energias novas do presente, a rasgar perspectivas deslumbrantes ao porvir". ${ }^{329}$ Falta, portanto, uma ruptura libertadora com o passado, uma superação das ideias e mazelas herdadas do Império. Nessas palavras nota-se uma clara, e talvez imediata demais, relação entre monarquia e atraso, república e avanço. O uso da ideia de um "antigo regime" e a crença na civilização americana, da mesma forma que a apologia à espada do marechal Floriano Peixoto, revelam uma concepção revolucionária progressista, que remonta aos marcos 1776 e 1789 (ou 179394), criando mais estereótipos do que análises. Na pena de Motta Lima, portanto, combater o saudosismo era fazer a revolução republicana completa, algo que se tentara nos tempos de jacobinismo, mas que, por ser mais cômodo, devido à desilusão ou interesse político, não se fizera. O que se tinha, agora, era uma República incompleta, que vegetava à mercê dos retrógrados, um regime de continuidade cuja juventude, cultuando ídolos do passado, restava iludida.

Epígrafe e introdução armaram o cenário da obra; entremos, agora, e definitivamente, na seara do texto. No prefácio de Sussekind de Mendonça, chamado "Primeiras palavras", estão definidos, com mais clareza, as intenções e referências de seu livro; está traçada, inegavelmente, uma intenção de debate e polêmica. Um fato se destaca logo de saída, é aquilo que dá o mote à obra: o repúdio às comemorações, em 1925, pelo centenário de d. Pedro II. A partir daí, o principal oponente, que vai ser combatido ao longo de todos os textos, é prontamente discriminado e caricaturado:

\footnotetext{
${ }^{329}$ Pedro Motta Lima. "Introdução". Op. cit., p. 12.
} 
“atendendo ao apelo do Instituto Histórico - que é o último reduto do 'sebastianismo' brasileiro - governo, burguesia, nobreza e clero, todos se persignavam diante da memória secular do "magnânimo"'. O Instituto Histórico e Geográfico Brasileiro - e perceba-se como o IHGB é estratégico tanto para os defensores quanto para os detratores do monarca, o que revela o risco e a produtividade do arranjo entre conhecimento e política -, pego em flagrante delito, surge como o grande vilão; é a organização que, de modo retrógrado e elitista, cultua o passado e, mais do que isso, congrega, na sua festa da memória, todos os setores responsáveis pela exploração de classe. Cria-se, assim, com notória intenção política, uma história de cunho oficial e alienante, que permite aos "lacaios do Paço, que ainda os há entre nós", sorrir e celebrar, dando larga vazão aos seus interesses; "tripudiando sobre as facilidades do governo e a tolerância incorrigível dos republicanos", impingiram "a cerimônia centenária como mais uma prova da "justiça de deus na voz da História"”. A principal preocupação do autor, em meio a todo esse culto passadista, é com o "povo" - que, note-se, não é, em momento algum, bem definido e nuançado, permanecendo sempre uma instância genérica. Que achava ele, o povo, disso tudo? "Eterno espectador bestificado de todas essas farras mais ou menos oficiais - não reprovou, nem aderiu. Fez de Maria vai com as outras”. Apartado dos meios de conhecer a verdade, a população acreditou, conforme lhe diziam as autoridades e os doutos senhores do Instituto, que o monarca "era a maior encarnação do Bem, do Sábio, do Justo e do Perfeito, ele não viu inconveniente em lhe fazer o coro à Bondade, à Sabedoria, à Justiça e à Perfeição". É nesse ponto que se justifica a obra de Sussekind de Mendonça; sua coletânea de artigos visa, justamente, combater essa historiografia pautada em uma concepção transcendente e apolítica do monarca, e lançar vistas largas sobre um futuro que pode ser promissor, desde que se escapa à pasmaceira saudosista. Como ele mesmo diz, revelando aspectos muito parecidos com alguns autores que critica, sobretudo no que diz respeito ao "povo criança":

Ora, já era tempo de que alguém se animasse a esclarecer o povo, libertando-o da praga periódica dessas mistificações.

O Brasil é um país novo, um país que começa, agora apenas, a viver.

Querer, a todo transe, convencê-lo das excelências de um Passado que não teve, da necessidade de se conservar fiel a uma tradição que não existe, do benefício que lhe possa advir da observância de uma norma que nunca foi cumprida senão na ficção de meia dúzia de cretinos, incapazes de entreter em ocupações mais sérias a sua perpétua ociosidade - é tão 
grotesco, é tão estúpido como se se quisesse coagir uma criança, que já anda, a engatinhar de novo.

Fez muito bem, portanto, "A Esquerda", tomando a si, de ânimo sereno e consciência satisfeita, o encargo de mostrar ao nosso povo que o "saudosismo", com que o engodam, não passa de um papão, na verdade bem feito, com todas as aparências necessárias a iludir a mais esperta, a mais prevenida das criaturas, mas, no fundo, papão, como todos os outros, que só assustam e impressionam enquanto iludem por seus truques ignorados. ${ }^{330}$

Uma obra, portanto, pensada e feita para o povo - até onde esse objetivo se cumpre, é difícil dizer; um panfleto, de linguagem solta e desinibida, mas metodologicamente bem firmado, que visa libertar uma jovem nação de um passado idealizado e dominador, da praga das mistificações, do "papão" com a qual lhe nutrem e assustam. D. Pedro II é a pedra angular sobre a qual vertem as críticas; é o tendão de Aquiles dos passadistas, o foco da acusação, a peça a ser removida a fim de desmontar a engrenagem dos mitos saudosistas. A estrutura do livro, nesse sentido, é muito interessante e cumpre bem a função, que advoga deliberadamente para si, de ser um libelo. Além das primeiras e últimas palavras, que vêm como introdução e conclusão, contam-se oito capítulos, que abordam temas distintos, dando um panorama vasto do mito a ser demolido. São eles: "Pedro II de relance"; "Pedro II, político"; "Pedro II, poeta"; "Pedro II, abolicionista"; "Pedro II, pacifista"; "Pedro II, democrata"; "Pedro II, financista"; e, por fim, "Pedro II, o sábio". Todos os capítulos são divididos em pequenos subtítulos, alguns dos quais não passam, às vezes, de parágrafos únicos e breves. Isso garante certo dinamismo ao texto, tornando-o panfletário, verdadeira saraivada de críticas, algumas bastante bem humoradas. O leitor, ao tomar conhecimento dessas linhas, pode ser envolvido de tal forma pelos ataques ao monarca que, talvez, não encontre alternativa, começe a gostar e divertir-se, não conseguindo criar distanciamento. Contribui para isso o fato de que o autor combate, mais do que tudo, os monarquistas da República; logo, os ataques sempre repercutem em um presente que é conhecido e vivido, um contexto próximo. É, portanto, um movimento constante de ida ao passado e volta à atualidade; um vai e volta que, ao se realizar, não deixa pedra sobre pedra.

A obra abre-se de forma dura; ao tratar d. Pedro II "de relance", este é o primeiro comentário de Sussekind de Mendonça: "O estudo relativamente longo, que fiz da história do Segundo Reinado, deu-me convicção de que o maior elogio que se pode

\footnotetext{
${ }^{330}$ Carlos Sussekind de Mendonça. Quem foi Pedro II. Op. cit., pp. 15-17.
} 
fazer ao segundo imperador é chamá-lo de medíocre”. Não há margem para tolerância, nada há que salve; ele foi um sujeito absolutamente pífio, em todos os aspectos: "medíocre como homem público, como homem na vida íntima, medíocre no tocante às coisas de estratégia, medíocre no que tange às concepções científicas. Note-se que, a meu ver, em tal julgamento há excesso de benevolência”. Nessa passagem, percebe-se algo interessante: para combater de frente o saudosismo, é preciso agir de forma indistinta, atacar, com os mesmos golpes, todos os corpos do rei, sua transcendência e sua imanência a um só tempo. Somente assim é possível revelar que, através da fácil e tentadora louvação do passado, foram "atribuídos ao imperador atos que não praticou, sentimentos que não teve, e isso, casado com o espírito de oposição ao governo, existente em nossa terra, leva a grande massa de cidadãos a exaltar a honestidade administrativa, deprimindo, implícita ou explicitamente, a administração republicana". Apesar de uma evidente operacionalização do passado ser usada para balizar o entendimento do presente, de acordo com Sussekind de Mendonça, é preciso perceber, também, os vícios da República, pois esta está longe de ser a ideal. Mas, sem ilusões; a raiz de todos os males, um fato inconteste, é profunda e unívoca, deve ser procurada no Império. E complementa, sempre comprando alguma briga: "tais vícios, em que pese a opinião dos sebastianistas, têm diminuído consideravelmente, e tendem a desaparecer, à medida que surge a nova geração que não teve a infelicidade de presenciar as cenas de cativeiro". 331

O livro, portanto, quer tocar os brasileiros da nova geração, já nascidos sob o regime republicano; é interessante perceber como isso é muito bem trabalhado na lógica interna da obra. No primeiro capítulo, há um subtítulo chamado "Ilusões de menino e estudos de rapaz", no qual o próprio Sussekind faz uma mea-culpa e desvenda a forma como veio revisando, desde a juventude, suas opiniões acerca do imperador; ou seja, o autor cria empatia para com o público que quer alcançar, demonstra como, ele também, já admirou, outrora, aquele que hoje que desbancar. Importante perceber, contudo, como o seu encantamento para com a imperial figura seguiu caminho completamente distinto daquele, a título de exemplo, seguido de Magalhães de Azeredo. Este, ficara magnetizado pela presença do soberano, por seu porte absolutamente imperial; uma admiração completa, desde os aspectos físicos até, principalmente, os morais. Com Sussekind de Mendonça, não; seu encanto e desencanto jamais se deram por fatores

${ }^{331}$ Carlos Sussekind de Mendonça. Quem foi Pedro II. Op. cit., p. 22. 
sensíveis, é sempre o estudo e o esforço intelectual que dão o norte às suas opiniões. Diz assim nosso autor: "fui, na meninice, entusiasta do Sr. D. Pedro II e tive entusiasmo ardoroso que conservei enquanto li apenas as obras onde se dizia que era justo, sábio, patriota, cavalheiro, liberal...”. A crise das ilusões, contudo, sobrevêm quando, libertando-se da bibliografia controlada e laudatória, ampliando o repertório e buscando novas fontes, o ensaísta teve "de ler trabalhos diferentes daqueles que, antes de publicados eram lidos nos serões de S. Cristóvão"; quando precisou, realizando trabalho de historiador, "ler anais do parlamento, falas do trono, correspondências, notas diplomáticas, documentos, em suma, que não podiam ser alterados ao sabor dos interessados". Foi somente a partir desse esforço que adquiriu "convicção oposta à que trazia da puericidade". ${ }^{332}$ Ressoa, nessas palavras, uma crítica pungente, apesar de um tanto escamoteada: qual era, até então, a maneira de abordar d. Pedro II? Como se davam as pesquisas: procurava-se direto nas fontes ou se faziam meras conjecturas laudatórias, frutos de especulação e interesses específicos? Dessa maneira, Mendonça é mais um autor que clama pela inabalável veracidade dos documentos, pelo quinhão de originalidade dos arquivos; diante da materialidade do papel e tinta, não haveria argumentos em contrário. Neste caso, entretanto, não se trata de usar documentos para louvar o monarca, tal como faziam seus defensores; é exatamente o oposto: buscar nos anais do Império tudo aquilo que desmentisse as versões oficiais, que colocasse o saudosismo em maus lençóis.

Apesar dessa apreciação de cunho metodológica, mesmo que feita de modo um tanto enviesado, Sussekind de Mendonça, em seu esforço crítico, não se faz, em momento algum, de muito rogado. Ao longo dos artigos, perscruta diversos detalhes, mesmo os mais pessoais, aqueles que, em certos momentos, poderiam escapar à alçada da objetividade. A certa altura, por exemplo, comenta a relação de Sua Majestade com a imperatriz Teresa Cristina. Nesse sentido, diz que após a superação de todas as dificuldades diplomáticas e a sobreposição das desconfianças - quando, por fim, concluíram-se as imbricadas negociações que resultaram na escolha de uma noiva -, o monarca não teve a hombridade necessária, muito menos a gentileza suficiente para esconder sua decepção em face da aparência da moça. Foi incapaz, também, nos longos anos de convivência matrimonial, de compreender a grandeza moral demonstrada pela imperatriz. Dito isso, e indo mais além, entende-se que "o Sr. Pedro II foi homem

\footnotetext{
${ }^{332}$ Carlos Sussekind de Mendonça. Quem foi Pedro II. Op. cit., p. 23.
} 
incapaz de afetos duradouros e verdadeiros". Era, portanto, acima de qualquer coisa, um homem sem compreensão, sem tato humano e político; incapaz, portanto, de bem governar o povo brasileiro.

Do detalhe quase íntimo, da relação matrimonial entre homem e mulher, Sussekind vai subindo de esfera e de tom, parte em busca de outros exemplos, outras evidencias da aspereza do caráter de d. Pedro II. Estamos, assim, diante de um jogo de escalas e dimensões que, mesmo variadas, estão plenamente conectadas: do mínimo e do pessoal, alcança-se o amplo, o político e o nacional. Dessa forma, o autor toca, por exemplo, o assunto do abolicionismo, pelo qual, supostamente, o imperador demonstrava grande entusiasmo. Segundo Sussekind, a questão dos escravos fornece “provas outras, múltiplas e insofísmáveis, da aridez do coração do monarca decaído". O imperador nada tivera que ver com a abolição; “o aniquilamento da escravidão", como não poderia deixar de ser, ao menos na perspectiva de um autor assumidamente de esquerda, "da abolição do tráfico à lei de 13 de maio, é obra exclusiva de nosso povo. Não houve colaboração dos imperantes que, ao contrário, puseram toda sorte de obstáculos à humanitária e sacrossanta cruzada". Sobre esse tema, Sussekind é irredutível e, contestador, sobe o nível das críticas; propõe um desafio aos aduladores do monarca: "que me citem fatos que demonstrem a colaboração de Pedro II na obra de redenção da raça negra". Afinal, "sempre que a raça perseguida, ingenuamente, quis abrigar-se sob o manto imperial, aí não encontrou corpo onde batesse um coração vivo, e teve a impressão de encostar-se numa estátua de mármore". ${ }^{333} \mathrm{O}$ abolicionismo do monarca, como vem dito em um dos subtítulos da obra, era "puramente verbal", jamais verteu-se em ação. Não se pode, assim, fazer afirmações que não se confirmem nos fatos e relatos; mais do que isso, "não é crível que homens, que consagraram a vida à causa da abolição, não conhecessem o seu histórico ou tivessem a falta de honestidade capaz de negar o título de abolicionista ao imperador, se este o tivesse merecido".334 Seria o mesmo que duvidar da palavra dos grandes heróis nacionais, dos defensores da causa mais justa de todas. Percebe-se como o autor trabalha muito bem o discurso de seu libelo: a expansão do pessoal ao geral, as negações peremptórias e o desafio, o uso de imagens elaboradas e metafóricas, a busca por apoios e alianças, são todos elementos que compõe e dão sabor ao seu texto. No entanto, fica uma pergunta: ao desmantelar as

\footnotetext{
${ }^{333}$ Carlos Sussekind de Mendonça. Quem foi Pedro II. Op. cit., p. 25 e pp. 27-28.

${ }^{334}$ Carlos Sussekind de Mendonça. Quem foi Pedro II. Op. cit., pp. 73-74.
} 
opiniões positivas a respeito do monarca, o autor não acaba, por sua vez, fazendo afirmações discutíveis e saturadas, tal como o seu comentário sobre a redenção dos escravos ser, exclusivamente, uma obra do povo brasileiro, esse mesmo povo que, algumas páginas antes, fora tachado bestializado e Maria vai com as outras? Dessa maneira, cria-se um jogo de opostos, no qual o desmonte de uma memória está na base da elaboração de outra, sendo que uma não está livre dos mesmos dilemas e contradições encontrados na oponente.

Outro exemplo do que vem dito acima: as críticas ao suposto pacifismo do monarca. A crer em Sussekind de Mendonça, d. Pedro II era tudo, menos um defensor da paz; "o imperador foi, ao contrário, sempre e sempre, por vocação, instinto, herança, hábitos e conveniências - belicoso". A guerra contra o Paraguai, nesse sentido, o maior evento bélico do Segundo Reinado, teria sido, além de um meio de dar vazão aos pendores belicistas do monarca, um "expediente para distrair comoções intestinas, meio de se prestigiar e ao trono aos olhos do país, pretexto pueril para persuadir o continente da nossa sempre desastrosa hegemonia". Mas não só isso, e é aqui que podem começar a se fazer sentir com mais força as opiniões negativas, o conflito fora, também, um “truque para tirar desforras pessoais e até - 'capa' para favorecer o armamentismo mercenário do Sr. Conde d'Eu'. O monarca emerge, dessas palavras, um tanto megalomaníaco, sedento de poder e sangue, querendo dominar as Repúblicas fronteiriças e disposto a favorecer os seus próximos. Tanto o é que, de acordo com Mendonça, o imperador só passou a defender a intervenção militar quando ela se tornou, para ele próprio, um bom negócio; antes de haver retornos garantidos, "os interesses do Brasil e a honra dos brasileiros sofriam, sem repulsa, todos os vexames". Ou seja, o arranjo estava descompassado, fatores que deveriam ser complementares surgem isolados e mesquinhos; antes do nacional, o que pesava na balança de d. Pedro II era sua imagem pessoal: "quando se achava em jogo a dignidade nacional - ele se retraía; mas, se o que se expunha era a sorte do trono ou a sua 'grosseira vaidade' hegemonística - todas as cóleras desencadeavam, sem o mínimo controle”. A Guerra do Paraguai, nessa lógica, teria ocorrido, acima de tudo, porque d. Pedro II quis bloquear os ímpetos imperiais de Solano López - não por diplomacia, mas por inveja pessoal, por medo de um rival tão próximo. Sempre se baseando em "documentação", Sussekind demonstra como o Paraguai tivera, durante todo o período precedente à guerra, atitude lisa e diplomática; como foi o ímpeto hegemonista brasileiro, personalizado na figura do 
monarca belicoso, o causador do conflito. A intervenção fora um erro, e a cegueira dos aduladores permanecia uma vergonha para o Brasil, símbolo de preconceito e patriotismo inconsequente. Sussekind de Mendonça, entretanto, pensando nos contraargumentos que poderia ouvir, estruturara suas ideias de forma a superá-los. Dessa maneira, comenta que, mesmo admitindo-se que a causa da mobilização fosse a salvaguarda dos interesses nacionais, "compreender-se-ia, neste caso, apenas, a repulsa à agressão - nunca a 'guerra de extermínio', alimentada unicamente pelo ódio pessoal, durante cinco anos". Quando todos queriam a paz, quando os exércitos estavam extenuados, quando López já entregara os pontos, "o único inimigo da paz no Brasil" era ninguém menos que o próprio monarca; “ele, Pedro II, o 'magnânimo' o 'pacifista', queria ir até o fim, até a morte de seu adversário pessoal". Nessa busca da desforra particular, a guerra ganha ares de comédia teatral, principalmente quando o monarca vai para frente de batalha. Segundo nosso autor, ele fez isso porque queria explorar ao máximo o que a guerra lhe podia oferecer. $\mathrm{Na}$ corte, em meio à crise política e financeira, Olinda discursava e chorava na câmara, lembrando o sacrifício do monarca, que deixara para trás o conforto e a segurança para representar o país no fronte; na imprensa, nacional e estrangeira, desenhos, por certo bastante bem remunerados, representavam um Pedro II destemido e em poses triunfais. Tudo, na pena de Sussekind, vai ganhando contornos patéticos e falaciosos. O que mais revolta o autor, no que tange à Guerra do Paraguai, algo que se refletiria tão bem nas loas de seus aduladores saudosistas, é a hipocrisia e o aspecto ardiloso do monarca, a "dupla-face com que ele assume todas as suas atitudes guerreiras"; assim, "no mais aceso das lutas, no período mais agudo das crises, suas falas do trono têm sempre blandícias e protestos de vítima". 335

Demolida a imagem do pacifista, hora de ir atrás de outros focos para, a partir deles, continuar a desatar o arranjo. No que diz respeito à faceta de versejador e homem culto de Sua Majestade, nenhum autor vai ser tão citado por Sussekind, os motivos para isso são óbvios, do que Medeiros e Albuquerque. Os comentários desse "colaborador" acerca das poesias do imperador, além da suposta fraude nos Sonetos do Exílio, são um prato cheio; na lógica interna dos artigos, que vão, à semelhança da introdução de Albuquerque às poesias completas de d. Pedro II, do detalhe ao todo, é fósforo riscado sobre um barril de pólvora. Com algum requinte de crueldade, Sussekind cita vários dos

\footnotetext{
${ }^{335}$ Carlos Sussekind de Mendonça. Quem foi Pedro II. Op. cit., pp. 83-85, p. 89 e pp. 98-99.
} 
poemas do monarca, ridicularizando-lhes as qualidades literárias, apontando-lhes as fragilidades estéticas e fazendo pouco caso dos versos e estrofes imperiais. Sobre um dos sonetos, chamado "Saudade da pátria", diz o seguinte: "na indulgência de rimas e ideias, o versejador chega a rimar saudade com saudade - o que, como rima rica, é o mais que se pode desejar, sobretudo sabendo-se que, em português, há cerca de 450 rimas em "-ade"". 336 Quanto às traduções, essas Sussekind chama de "atentados", "desgraça", "massacres", "corpo de delito", "crime". Os autores traduzidos são tratados como "vítimas"; o tradutor, como "bárbaro". A intenção, pura e simples, é ridicularizar, mostrar provas de tudo o quanto fala; quer reproduzir, além de analisá-los, vários poemas e traduções, somente para não ser acusado de ter escolhido os piores dos sonetos imperiais para figurar em seu livro. Como se propõe, desde o título, golpeia o saudosismo, de frente; se a verve poética de sua majestade, tal como seu conhecimento múltiplo e vasto, era um dos aspectos mais lembrados por todos aqueles que o defendiam, esse deveria ser um dos principais focos. Por conta disso, é preciso desmistificar, evidenciar as falhas, dar provas cabais da incapacidade do monarca.

As informações do parágrafo anterior são importantes para inserir o autor na polêmica, no debate que queria fomentar. Como já comentado, seu maior opositor era o Instituto Histórico e Geográfico Brasileiro; e é esta instituição que será o alvo das críticas mais furiosas e avassaladoras. Antes, recorde-se um aspecto: se Max Fleiuss, como já comentado, veria, no ano de 1940, em d. Pedro II o rei prometido, o monarca ideal para esta nação, pátria que rumava para as glórias desde os tempos da colonização; se d. Pedro II seria o elemento de conexão entre o passado e o presente, o elo harmônico de ligação, conector de uma história sem rupturas e conflitos, Sussekind de Mendonça, por seu lado, faz justamente o contrário. Seu Pedro II só pode ser criticado e combatido, nada além disso; não é um exemplo ou modelo a ser seguido, é, pelo contrário, um vulto a ser demolido e, depois, prontamente esquecido. Neste texto de 1929, aborda o monarca para propor uma ruptura, negar a continuidade, combater o vislumbre encantado do passado que achincalha o presente e bloqueia as perspectivas de futuro. Interessante perceber como é justamente ao tratar do d. Pedro II versejador que começa, de forma mais evidente e aguda, a atacar o IHGB. Ou seja, justamente aquilo que garantiria autolegitimidade à obra de Max Fleiuss - o ciclo fechado: tema, estilo e instituição - é o que vai servir de marreta destruidora para Sussekind de Mendonça. É o

\footnotetext{
${ }^{336}$ Carlos Sussekind de Mendonça. Quem foi Pedro II. Op. cit., p. 61.
} 
desmonte da imagem do imperador culto e sábio, aquilo que parece ferir mais o orgulho de seus aduladores. Este o ponto sensível, porque é precisamente ele que consolida a legitimidade dos saudosistas. Nesse sentido, assim diz nosso autor: "qualquer sobrecasaca do Instituto Histórico a quem se peça opinião sobre as quadrinhas do Bragança, dirá que elas são 'magníficas' e 'dignas de figurar no escrínio de qualquer literatura". Tudo se trata de ilusão, uma mentira imposta ao público; este, o povo, o elemento mais importante da equação, não "lê nem os elogios dos Srs. Afonso Celso, Max Fleiuss ou Mesquita Pimentel - nem as tolices do Sr. Pedro II. O público ouve dizer que o velho imperador fazia versos". O pior de tudo é que, nessa toada segue a crítica, "como nenhuma história da literatura brasileira os encerre [os versos de d. Pedro II], nem a eles se refira, para o louvor ou para a oposição - a versão dominante terá de ser, forçosamente, a única”. Dessa maneira, escondendo os rastros e ludibriando o entendimento do passado, "o senhor Pedro II passará por ter sido, realmente, um poeta, um bom poeta mesmo".337

Sobre o tema da cultura científica do monarca e "os zelos que lhe despertavam o preparo próprio e o do seu povo", Sussekind parte para o ataque pesado; seria esse um assunto sobre o qual "o 'saudosismo' se demora, com acentuada volúpia”. Os elogios ao conhecimento múltiplo do imperador andariam, como bem se sabe, "por todos os panegíricos que fazem ao Segundo Império". Mas, onde mais se faziam sentir era na “interjeição histérica das perpétuas da Lapa, quando ostentam casaca e os crachás dos grandes dias e se sentam nas mesmas cadeiras em que o magnânimo, se dava aí desfastio de sentar, também, às vezes, as suas partes vergonhosas". E quem seriam essas perpétuas da Lapa, trajadas de casaca e ostentando crachás, senão os membros do IHGB, instituição cuja sede, até hoje, fica nas proximidades do bairro da Lapa? Toda essa falação acerca da cultura do rei "não passa, todavia, de uma grande, de uma fantástica, mistificação. Pedro II não foi sábio - nem nunca se importou, senão para perorá-las, com as coisas da instrução". Por conta disso, o autor brada a viva voz: "Reflita, um pouco, o 'saudosismo e - que diabo! - confesse que, ainda aí [na tão propalada cultura do monarca] como das outras vezes, como sempre, 'a justiça de Deus' não está muito de acordo com 'a voz da História'”, 338

\footnotetext{
${ }^{337}$ Carlos Sussekind de Mendonça. Quem foi Pedro II. Op. cit., pp. 52-53.

${ }^{338}$ Carlos Sussekind de Mendonça. Quem foi Pedro II. Op. cit., p. 149, p. 151 e p. 163.
} 
Desse tema, me parece que seja possível concluir uma ideia. Ao criticar a suposta cultura de d. Pedro II, o que está em jogo é toda uma produção historiográfica e intelectual que trata desse tema, assim como a legitimidade de uma determinada forma de fazer política, de um arranjo político ligado à cultura. Só defenderia a inteligência do monarca aquele que quer justificar seu próprio lugar na inteligência e na política brasileiras pós-Império, tal como é o caso das "perpétuas da Lapa", que precisam celebrar o passado para manter viva sua legitimidade, para não serem engolidas pelas novas teorias e produções. Os detratores, por outro lado, são aqueles que querem conquistar seu espaço, querem propor mudanças, não só de cunho cultural, como também político e social. O caso de Sussekind de Mendonça é exemplar: a agressividade de seus ataques - e é isso o que está em sua base - não se limita a uma revisão historiográfica, ao questionamento de uma prática e método antiquados; é, isso sim, uma efetiva tomada de posição política, uma afirmação da República em detrimento do passadismo saudosista. Logo, clama por uma nova visão acerca da história, uma concepção que mire as gerações futuras e não seja "retrospectiva"; que, diferente do olhar "vesguinho, viciado, interpolado, das perpétuas da Lapa", seja "o honesto, o leal, o desprevenido, o desinteressado, das estatísticas e dos depoimentos livres". 339

Somente assim, endireitando a perspectiva sobre o passado, seria possível negar os ímpetos "sebastianistas" e questionar as supostas virtudes abolicionistas, pacifistas, democráticas e culturais do velho imperador. Pois são exatamente dessas virtudes que “o ‘saudosismo' faz questão fechada; acredita-se, por exemplo, que o monarca foi quem fundou a democracia brasileira, instituindo-a sobre bases rígidas e inflexíveis que fazem hoje inveja às práticas republicanas". A crer em suas afirmações, não é possível perceber as falácias do discurso saudosista, não se evidencia a herança negativa do Império, não se criam novas perspectivas. Segundo Sussekind, ao invés de democracia e inteligência, "recrutamento, Guarda Nacional, polícia e magistratura - tais eram os quatro pés em que se assentava a 'legitimidade' monárquica no Brasil”. Mais ainda, quando das eleições - tão cultuadas pelos aduladores como um símbolo do espírito democrático de d. Pedro II -, caso fosse preciso para se apurar a vitória do governo, "intervinham os capangas, o cacete rufava e, ao reluzir das facas e ao estrugir dos tiros, espargindo por vezes, sangue nos altares da religião oficial [as votações se realizavam

\footnotetext{
${ }^{339}$ Carlos Sussekind de Mendonça. Quem foi Pedro II. Op. cit., p. 112.
} 
dentro das igrejas]". É essa, tal como conclui nosso autor, “a democracia do Sr. Pedro II", a democracia que foi herdada pelo regime de Quinze de novembro. No entanto, "para quem assiste a uma sessão retrospectiva do Instituto Histórico", não restam dúvidas de que a "República desgraçou o país arremessando-o da 'fartura e da prosperidade' que fruía com o Sr. Pedro II para a 'anarquia e o descalabro' que nos vem perseguindo desde 1889 ".340

Mas, fica uma pergunta ainda em aberto; diante de tantas inverdades e ilusões, o que é preciso fazer? Como derrotar de vez esse saudosismo que deturpa o entendimento do passado e prejudica a ação no presente? A resposta de Sussekind de Mendonça, como ele diz em suas "últimas palavras", é bastante clara e direta: é preciso, de uma vez por todas, esquecer o imperador. Apesar de um pouco longa, a citação merece ser integral:

Já é tempo, pois, de que se faça ao Sr. Pedro II a única justiça que merece - a de o esquecermos.

O Brasil vive, hoje, uma hora de grandes anseios, que ninguém pode, por enquanto, precisar até onde nos conduzam.

$\dot{E}$ uma grande nação que olha pra frente e não tem tempo, absolutamente, de voltar, mais, os olhos para trás.

O que ficou, ficou - tem de ser este o lema, simples, cômodo talvez, mas necessário, imprescindivel mesmo, ao cumprimento do dever que nos assiste a todos, moços, velhos e crianças - gente do Brasil.

$O$ "saudosismo" é pulha, no entretanto.

Ele não perde ocasião de espreitar os menores desfalecimentos dessa luta que a República já trava com uma aspiração maior, mais ampla, mais nova do que a sua.

E é de ver a torpeza com que golpeia, à traição, os espíritos mais fracos, vingando o golpe de 89 com um derrotismo sem finalidade, feito somente para destruir a obra dos adversários triunfantes. repeli-lo.

Urgia, assim, que alguém parasse, em meio do caminho, para

E derrubasse, de uma vez por todas, os seus ídolos, os seus bonzos, os seus fetiches e tabus de toda espécie, papões indignos de atemorizar, nos dias de hoje, a mais tola das crianças.

Foi o que eu quis fazer e acredito ter feito.

\footnotetext{
${ }^{340}$ Carlos Sussekind de Mendonça. Quem foi Pedro II. Op. cit., p. 114, p. 126 e p. 130. Note-se um fato curioso, que demonstra a habilidade argumentativa do autor. Sussekind de Mendonça acusa d. Pedro II de ter, ao longo de seu reinado, aumentado a sua dotação e a de sua família, além de ter feito gastos abusivos, como os de 1842, quando de seu casamento. Mais interessante é que, para fazer tais críticas, ele utiliza dados presentes na obra do mais famoso "saudosistas" do IHGB, o Sr. Max Fleiuss e sua História administrativa do Brasil. Outro ponto de acerbadas críticas é o ano de 1864, quando do início da Guerra do Paraguai e do auge da crise financeira; nesse ano, segundo o autor, os gastos foram excessivos e, pior, superficiais e inúteis. Como resultado disso tudo, ficou o (trata-se de um subtítulo) "déficit que a República herdou do Império": "Aí têm, portanto, os "saudosistas' de todos os matizes este fato eloquentíssimo - o Império, o próspero, o florescente, o rico Império do Brasil, sob as rédeas do egrégio financista, Sr. Pedro II, passou o erário nacional à República - é o Sr. Max Fleiuss quem diz - com déficit de 26.115:000\$000! Será preciso comentar a eloquência destes números?”, p. 146.
} 
Fixem-se, pois, mais uma vez, os únicos propósitos deste livro.

Não pretendo aventurar mais um estudo sobre Pedro II.

Não tenho tempo, nem vontade, nem dinheiro para isso.

O que quis foi tornar acessível a qualquer inteligência - foi colocar à mão do povo - o antídoto que, às vezes, é preciso ministrar às gerações republicanas para que se defendam do veneno "saudosista".

Fiz mal? Fiz bem? Não sei. Sei, só, que fiz. E isso me basta. ${ }^{341}$

O autor, como bem se nota, encerra o texto de forma irredutível. Atribui, a si próprio, uma missão que era necessária e premente, e que por isso mesmo a cumpriu. Se fez bem, se fez mal, não é exatamente essa a pergunta a ser colocada. Sussekind, e isso lhe basta, advoga uma autolegitimidade, uma função de consciência crítica do povo e da nação, que há bastante tempo andavam necessitados de romper com os saudosismos. Certamente, há muito de exagero e pretensão, mas há, e isso é marcante quando se pensa no contexto e na supervalorização da memória do monarca, uma corajosa tomada de posição. Com seus prós e apesar de seus contras, é interessante dar ouvidos a essas palavras finais, principalmente à ideia de esquecimento nelas manifesta. Porém, é preciso nuançar um pouco a proposta de esquecer o imperador, a única justiça que poderia ser-lhe feita, como supõe o autor. O esquecimento, como já foi dito ao longo deste trabalho, pode ser uma forma de entendimento e reflexão, uma recusa de todo excesso memorialístico que bloqueie e impossibilite o pensamento crítico. Sussekind de Mendonça, entretanto, quando fala em esquecer o imperador entende isso, ao que parece, de forma literal; quer apagar, definitivamente, uma parte do passado para que se possa, finalmente, olhar com liberdade para o futuro. Quer extirpar qualquer possibilidade de saudosismo, qualquer traição passadista a espreitar os espíritos mais fracos. Isso, porém, e felizmente, é impossível; por mais que se queira, o passado não se esvai por completo, o esquecimento jamais é absoluto, nada pode ser tão perfeito a fim de garantir buracos de esquecimento, como diria, num contexto bastante diverso, a filósofa Hannah Arendt. Além do mais, como lembra Beatriz Sarlo, “o julgamento amnésico da história é, entre outras coisas, uma afronta ao presente". ${ }^{342}$ Por isso, então, essa proposta de esquecer d. Pedro II soa tão incômoda aos ouvidos.

A conclusão de Sussekind, se um tanto exagerada, a ponto de se tornar quase uma falácia, é bastante reveladora em sua indignação, pois, assim como todas as flores com espinhos aqui selecionadas, mostra como a supervalorização do passado no

\footnotetext{
${ }^{341}$ Carlos Sussekind de Mendonça. Quem foi Pedro II. Op. cit., pp. 167-168.

${ }^{342}$ Beatriz Sarlo. "A história contra o esquecimento". In: Paisagens imaginárias: intelectuais, arte e meios de comunicação.Op. cit., p. 40.
} 
presente pode ser danosa e sufocante. Os excessos memorialísticos, quaisquer que sejam, devem, ao invés de repercutidos, ser problematizados e, talvez, combatidos. A proposta de esquecer sua Majestade, portanto, guarda certa relevância, mesmo que, na perspectiva defendida nesta dissertação, não seja exatamente a desejada pelo autor do candente libelo em questão. Golpear o saudosismo, mesmo que de frente, não significa que o ataque será, ao fim e ao cabo, completamente bem sucedido. Porém, de alguma forma, é necessário tentar. 


\section{Em vias de conclusão, mais algumas flores}

"É que meio século de viver no mundo deixa muita raiz que não morre assim. E talvez é uma só raiz, mas funda, e rija de febra e de seiva, que as folhas morrem, os ramos secam, o tronco apodrece, e ela teima a viver."

Almeida Garrett, em Viagens na minha terra

De tanto que se tratou de detalhes e fragmentos, paradoxos e controvérsias, esta dissertação, em si mesma, possivelmente guarda algo de fragmentário e paradoxal. Partiu da ideia dos dois corpos do rei para elaborar uma chave interpretativa sobre a forma de fazer política arranjada a partir de d. Pedro II; perscrutou a bibliografia mais conhecida e recente acerca do imperador para enfeixar um problema; se deteve sobre questões teóricas a respeito das relações entre história e memória para pensar o tema proposto; adentrou as décadas de 1920 a 1940, transitando entre textos de gêneros variados, a fim de rastrear indícios do imperador; abordou obras de oito autores distintos, cada qual lançando sua interpretação sobre o monarca, para documentar a diversidade de opiniões; finalmente, chegou até este ponto. Tal trajetória tortuosa e diversificada, talvez, seja uma consequência do próprio tema abordado; afinal, como se pode constatar, d. Pedro II, esse duplo ambíguo, foi motivo para diversas representações e controvérsias, muitas das quais se estendem na vida política brasileira - se meio século de viver no mundo já deixa muita raiz, como escreveu Almeida Garrett, o que dizer, então, de uma vida na qual meio século foi de reinado em uma nação escravocrata, surgida de uma colônia pontuada por interesses regionais distintos, cujo sentido, na famosa expressão de Caio Prado Júnior, era ser exportadora de gêneros tropicais para o mercado europeu?

Nas fontes analisadas, o monarca emergiu enquanto tema de elogios e críticas; alvo de pilhérias e contestações, foco de interpretações e leituras enviesadas da história nacional. Herói e vilão, apolítico e apático, messias e vulto a ser esquecido. Foi exilado e esquecido; retomado e exaltado. Amado e odiado. Seu corpo, cujos restos mortais foram trazidos de volta ao Brasil, foi velado, enterrado e celebrado. Agora, está em vias de ser exumado. Um tema, então, efetivamente, repleto de idas e vindas, que exige vistas largas para o seu entendimento. Além do mais, em momento algum a intenção foi restringir a pesquisa estritamente ao recorte estabelecido. Os anos entre 1920 e 1940, 
pela força memorialística que possuem, por representarem um contexto de confluências para se pensar a questão da memória, foram o foco aglutinador, o eixo pelo qual as questões e problemas teriam de passar; mas não foram, em absoluto, um limite e uma contenção. A relação entre memória e história, ao que parece, exige a circulação por temporalidades distintas; necessita, para ir além da superfície, do diálogo entre passado e presente. Afinal, como disse José Honório Rodrigues ao comentar a obra de Capistrano de Abreu, "o conhecimento dos fatos em ordem cronológica dá-nos apenas um esqueleto da história, mas não nos dá a compreensão da vida humana"; é preciso, portanto, instigar a "imaginação produtiva", preencher a problemática estabelecida com múltiplas indagações e referências.

Foi com essa ideia em mente que fiz a pesquisa. Não sem motivo, portanto, que o gatilho de todas as questões, o disparador inicial de indagação e estranhamento, tenha sido um artigo jornalístico, de novembro de 2007, retirado de uma revista de grande circulação. Artigo que, antes de qualquer coisa, evidenciou um modo controverso de tratar da história, assim como a longevidade de alguns temas que perpassam a memória de d. Pedro II - tais como o aspecto político de sua transcendência entre ciência e sagrado, modernidade e tradição; a valorização de seus sacrifícios, sua abnegação e sua postura conciliadora; a persistência de uma política baseada em preceitos morais, de uma política sem política. Em suma, no arranjo produtivo e complementar, mesmo que arriscado, de fatores de ordem aparentemente diversa; na combinação, o que cria um lugar legítimo e privilegiado de atuação, da erudição com o governo, da ciência com as estratégias políticas, da transcendência com a imanência. Ou, ampliando as referências, na fusão do poder com o sorriso, (tal como se lê no subtítulo de uma biografia recente sobre Getúlio Vargas ${ }^{343}$ ), do sociólogo com o presidente, do paz e amor com a reforma social.

Fica claro, então, que tal arranjo se mostra de longa duração na vida política brasileira e matéria rica para a memória; contudo, o risco também se revela, haja em vista que, ao longo dos anos e focadas sempre nos mesmos assuntos, emergem interpretações positivas e negativas acerca do imperador. José Lins do Rego e Sérgio Buarque de Holanda, Mário de Andrade e Menotti Del Pichia, cada qual tratou do monarca em termos parecidos para chegar a conclusões diferentes, para atingir, através de suas colocações, alvos distintos. Carlos Magalhães de Azeredo pensou em um d.

\footnotetext{
${ }^{343}$ Boris Fausto. Getúlio Vargas: o poder e o sorriso. São Paulo: Companhia das Letras, 2006.
} 
Pedro II pairando acima dos interesses político-partidários, nos "cumes da história”, nas regiões onde se dão os contatos entre "o humano e o divino"; era a combinação exata de um patriarca com um magistrado, cuja fisionomia moral deveria ser rememorada e servir de parâmetro para a República. Vicente Licínio Cardoso, ao tentar entender a formação profunda do Brasil, chega à constatação de que o imperador não soube lidar com as "realidades brasileiras"; o autor não olha para os cumes, mas para os subsolos da história, e, com tal mirada, conclui que o monarca falhou enquanto "realizador político". Emerge, nessa linha de pensamento, o imperador cuja transcendência está desconexa de sua imanência, o diletante e despreocupado, aquele que seria um bom rei para a Inglaterra, mas não para o Brasil. Nenhum autor exaltou tanto o rei-filósofo quanto Pedro Calmon, poucos trataram tão bem a produtividade da transcendência legitimada pela sabedoria, da política fora da política; fez disso, inclusive, uma ferramenta política nos meados da década de 1970, quando o regime militar precisava mostrar alguma abertura. Seguindo caminho oposto, nenhum autor identificou tanto os riscos desse arranjo quanto Medeiros e Albuquerque, ao ponto de escrever uma introdução para as poesias completas de d. Pedro II com o intuito único de revelar a fraude da cultura do monarca, o que nada mais era do que a fraude de sua política e de seu regime. Heitor Lyra, mesmo que tenha feito ressalvas e lembrado que nem tudo dependia da excepcionalidade do imperador, ressaltou, ao longo de três grandes volumes, a versatilidade de d. Pedro II, sempre o diferenciando dos políticos-políticos, tal como eram, por exemplo, os Andradas. Capistrano de Abreu, adotando o caminho da brevidade, ressaltou como d. Pedro II foi um estadista habilidoso, isso desde os tempos de menino-símbolo, quando foi comparsa da maioridade e teve mestres em excesso; não perdendo seu caráter transcendente, o monarca agiu sempre de forma imanente, foi um articulador e negociante, elemento ativo e inteligente, que se valia de artifícios e estratégias. Contudo, o foco de Capistrano é outro, daí porque mostra como o monarca não conseguiu lidar com o processo social que culminou na crise e no fim do Império. Max Fleiuss, a partir de referências bíblicas e clássicas - um repertório que lhe garante autoridade transcendental e imanente -, pensou em um d. Pedro II atemporal e apolítico, elemento capaz de reatar, da colonização ao Estado Novo, as fases de um verdadeiro épico nacional. Sussekind de Mendonça, ao querer combater de frente o saudosismo, atacou tudo aquilo que compunha o arranjo ambíguo do imperador, deslegitimou seus defensores e propôs apagá-lo da memória nacional; quis, acima de tudo, marcar a 
ruptura entre Império e República. Todos esses autores, sem exceção, cada qual a sua maneira, trataram do arranjo enfeixado no imperador, sempre lançando luz para aquilo que poderia estar mais de acordo com suas finalidades; assim, o arranjo de duplos é retomado e rearranjado, ora por seu aspecto apolítico e transcendente, ora por sua face política e imanente. Através da memória e da história revelaram riscos e produtividades, pensaram, para exaltá-los ou condená-los, aspectos duradouros da vida política e cultural brasileira.

Já que tudo começou a partir de um texto jornalístico, e a fim de reafirmar como permanece a força do arranjo e de sua memória, gostaria de abordar, em vias de conclusão, outra revista periódica; qual seja, o número 86, de novembro de 2012, da Revista de História da Biblioteca Nacional, cujo artigo de capa é dedicado a d. Pedro II. A principal reportagem que trata do imperador, assinada por Lorenzo Aldé, apesar de preocupada, por diversos momentos, em chamar atenção para o que é estranho no monarca e para alguns causos exóticos e curiosos, é muito interessante na medida em que trata de acesas controvérsias e contradições que envolvem o personagem, sem se ocupar, por conta disso, em operacionalizar o passado, em usá-lo enquanto uma referência banalizada para sugerir críticas políticas - o autor cita, inclusive, a conferência a respeito do "monarca cinzento nos trópicos", proferida por Gilberto Freyre na Biblioteca do Recife, e as biografias de Roderick J. Barman e José Murilo de Carvalho.

No texto da revista, o monarca é foco de divergências múltiplas; como vem dito a certa altura da reportagem, "juntar seus pedaços significa esbarrar, sempre, em grandes enigmas". Isso, contudo, não significa que esteja interditado problematizar o presente a partir da figura do monarca; em determinado ponto do artigo, o autor aborda uma entrevista feita com Roderick J. Barman, na qual o brasilianista, transitando entre temporalidades distintas, aproxima d. Pedro II e Luiz Inácio Lula da Silva. Trata-se de "uma tese controversa": ambos os governantes seriam populares, "encarnação das aspirações do país"; dignos e imponentes, são legítimos chefes de Estado; transformaram a imagem do Estado nação, tornando-a conhecida e repeitada pelo mundo; não representaram grandes ameaças, conseguiram se comunicar "com a gente simples e identificar suas necessidades". São dois personagens, nessa visão, cujos espectros possuem características em comum; duas figuras erigidas sobre ambiguidades 
e arranjos de duplos - acerca dessas ambiguidades e arranjos, note-se que um recente livro sobre o fenômeno do "lulismo" começa com as seguintes e intrigantes colocações: "O lulismo existe sob o signo da contradição. Conservação e mudança, reprodução e superação, decepção e esperança num mesmo movimento. É o caráter ambíguo do fenômeno que torna difícil a sua interpretação". ${ }^{344}$ A ideia de Barman, tal como aparece na reportagem, se pode soar estranha, não deixa de ter relevância, pois é apresentada enquanto uma hipótese (e, talvez, uma provocação?); em suma, é mais uma controvérsia a ser pensada e problematizada, não uma certeza. Como diz Lorenzo Aldé, o autor do artigo em questão, "a liberdade interpretativa é um direito inalienável de quem se propõe a ler a história, e tem o potencial de abrir novos caminhos". ${ }^{345}$

Nesse sentido, o que Barman fez foi abordar, em paralelo, dois personagens históricos, mas não com o intuito de criticar um deles à sombra do outro; o foco, assim, não resta estritamente nas qualidades individuais e nos traços biográfico, e sim nas questões de fundo que perpassam tais personalidades. Trata-se de um entendimento que leva em conta fatores comuns e estruturantes, e não um cotejamento limitado de diferenças e particularidades - o risco das comparações ficou claro, assim espero, ao longo do capítulo 4, por exemplo, quando, para o elogio ou para a crítica, vários autores pensaram a República a partir da referência a d. Pedro II e fizeram disso a chave de compreensão do presente. A intenção de Barman é, tomando o assunto em perspectiva ampla, propor uma indagação acerca da formação nacional e da consolidação do Estado brasileiro, e não apontar qual foi o melhor governante. A partir disso, cabe ao leitor fazer suas críticas; não há um bloqueio, por assim dizer, da opinião contrária e divergente. Há, como se percebe, um convite à reflexão. Dessa maneira, não se efetiva uma apropriação, com fins intransigentes, da memória; ela é, por outro lado, tomada de forma aberta e enquanto núcleo de problemas e indagações. Não se desequilibra, portanto, a correlação entre história e memória; não se obliteraram as mudanças e as continuidades históricas e nem se fazem comparações indevidas; afinal, a memória,

\footnotetext{
${ }^{344}$ André Singer. Os sentidos do lulismo. Op. cit., p. 9. Mais adiante, ao comentar os possíveis "sentidos do lulismo", o autor faz a seguinte, e historicamente tão lúcida, observação: "ao promover um reformismo suficientemente fraco para desestimular conflitos, ele [o lulismo, mesmo sendo um efetivo fator de modificação, sobretudo no combate à pobreza (monetária) absoluta] estende no tempo a redução da tremenda desigualdade nacional, a qual decai de modo muito lento diante de seu tamanho, em compasso típico dos andamentos dilatados da história brasileira (escravatura no Império, política oligárquica na República, coronelismo na modernização pós-1930)”, p. 22.

${ }^{345}$ Lorenzo Aldé. "D. Pedro II, quem explica?" In: Revista de História da Biblioteca Nacional. Ano 8, número 86, Rio de Janeiro, novembro de 2012, pp. 18-19.
} 
quando estabelecida sobre lugares-comuns, não esbarra em conflitos nem em controvérsias, ela cria lacunas e justificativas, favorece o bloqueio em relação ao outro, a negação da alteridade e o relato ensimesmado.

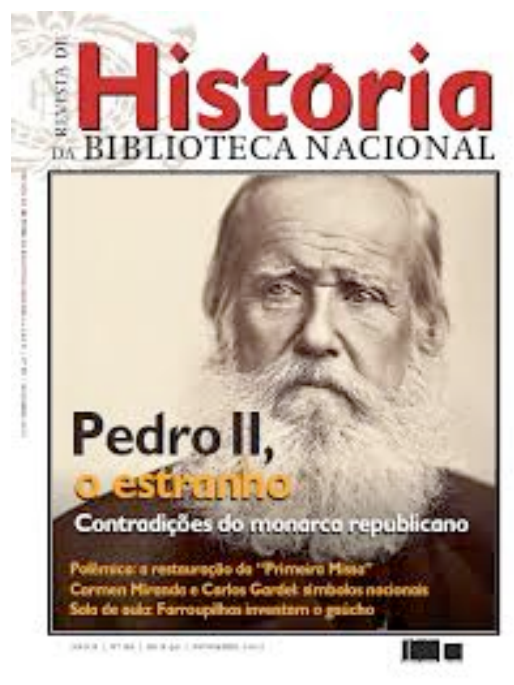

Capa da revisa $R H B N$, edição de novembro de 2012.

Dessas colocações se compreende, acima de tudo, como d. Pedro II continua sendo, ainda nos dias de hoje, personagem fundamental para se pensar a história do Brasil, como a eficácia histórica de sua memória continua forte. Mesmo com todas as tentativas de, positiva ou negativamente, enterrá-lo e superá-lo, permanece, em alguma forma, paradigmático; mesmo com os vários monumentos, obras historiográficas, biográficas e literárias, segue, com sua emblemática barba branca e sabedoria enciclopédica, a ser uma referência, efetiva superpessoa da memória nacional. Assim, no que diz respeito ao imperador, cujo legado continua vivo e atuante, a fim de escapar às armadilhas do passado, é sempre mais proveitoso pensar em retrospectiva. Daí porque é necessário, quando se trata de sua memória, pesar bem as medidas da lembrança e do esquecimento, olhar para o passado antes de pensar o futuro, fazer a crítica detida dos textos já escritos antes de produzir os novos. Lançar hipóteses e provocações, ao invés de certezas e verdades estabelecidas de antemão, esse pode ser o melhor caminho para perscrutar e compreender as formas como o passado vem à tona, $\mathrm{o}$ melhor caminho para medir o que as interpretação possuem de relevante e revelador - a intenção, portanto, não é julgar a historiografia, mas, através da leitura e crítica detidas, bem compreender as controvérsias, o sentido proposto e adquirido pelas ideias dos "sebastianistas", "louvinhadeiros" e "saudosistas", assim como pelas dos "demolidores", "desmistificadores" e "detratores". Pensar em retrospecto pode ser o 
melhor caminho, assim, para problematizar os excessos da memória que parecem, no limite, sufocar o presente. Como bem disse Beatriz Sarlo, entender é mais importante que lembrar, embora, para se fazer isso, é inevitável o próprio ato de lembrar. Lembrança e entendimento, então, aparecem como indissociáveis. Logo, está-se diante - tal como em toda a relação entre história e memória - de uma complexa complementaridade de fatores distintos. De qualquer forma, o esforço em compreender os elogios e as condenações feitos no passado, sobretudo em um período de tantas celebrações, confluências e controvérsias como os anos 1920/40, provavelmente é um bom começo, uma boa maneira de procurar por problemas e alternativas.

Nesse sentido, penso que, mesmo indiretamente, o caso de d. Pedro II traz à mente o paradoxo identificado por alguns intérpretes do livro Raízes do Brasil. Em linhas gerais, nessa obra de Sérgio Buarque de Holanda, o Brasil, a fim de superar suas raízes ibéricas, fomentar uma sociedade moderna e administrada com objetividade, deveria realizar uma revolução de cunho liberal, centrada em uma burocracia imparcial e funcional. Isso, porém, se consolidaria a superação de muitos dos dilemas nacionais, seria, no outro extremo do problema, uma desatenção à própria formação brasileira - o que evidencia como um pensamento de matriz liberal, mesmo sendo referência importantíssima para formular uma proposta de mudança, não dá conta de todos os problemas, nem permite estabelecer todas as questões. O historiador, dessa forma, ao mesmo tempo em que identifica um processo de formação e sugere possibilidades de transformação, se depara, entre continuidade e mudança, com um dilema. Nessa linha de pensamento, como disse Fernando Novais, ao comentar os capítulos finais do livro numa resenha publicada em maio de 1995, “o 'homem cordial' ficará sempre como referencial para indagar caminhos ou os descaminhos de nossa modernização, criticar a vulgata liberal e ao mesmo tempo apontar riscos de soluções extremadas à direita e à esquerda". Assim, no caminho de nossa modernização, emerge, como bem colocado por Novais, uma nota de controvérsia e pessimismo, uma esfinge que, mesmo não sendo definitiva, vem nos lançar o enigma: "ou nos modernizamos, e deixamos de ser o que somos; ou nos mantemos como somos, e não nos modernizamos". ${ }^{346}$ Abordar um legado como o de d. Pedro II, no limite, ao mesmo tempo em que revela, por um lado, os aspectos mais controversos de sua ambiguidade, fatores ainda presentes e atuantes

\footnotetext{
346 Fernando Novais. "De volta ao homem cordial". In: Aproximações: ensaios de história e historiografia. São Paulo: Cosac \& Naify, 2005, p. 323.
} 
em nossa vida cultural e política, torna essa mesma vida menos característica de seu próprio processo formativo (as colocações de Barman, logo acima, transparecem um pouco disso). De certa forma, Gilberto Freyre, em seu Ordem e progresso - um livro quase inviável, escrito sob o signo da crise, tanto do autor quanto do tema -, já pontuara essa questão, ao dizer que "o repentino triunfo republicano pôs alguns brasileiros em face do problema do futuro nacional, ao mesmo tempo em que os obrigou a considerar, no seu passado, singularidades que vinham sendo mal estudadas". ${ }^{447}$ A mudança de regime político colocara em primeiro plano algumas questões que estavam sendo esquecidas; ou seja, as transformações do presente, quando efetivamente ocorrem, trazem consigo um necessário pensamento sobre o passado. Dessa forma, percebe-se como nada se modifica sem despertar uma nota de paradoxo; o trato que se vai ter com o dilema, essa é a grande questão a ser posta em debate - ao longo desta dissertação, e espero que isso tenha ficado nítido ao leitor, foi possível compreender como esse trato pode ser muito variável e repleto de nuances, haja em vista, por exemplo, as formas como o povo é abordado, nos casos de Carlos Magalhães de Azeredo e de Sussekind de Mendonça, um defensor, o outro detrator do monarca, como um povo criança, um aglomerado amorfo a ser instruído por uma instância maior: seja pelo pai/sábio/imperador, seja pelos republicanos conscientes do caráter postiço da sabedoria de d. Pedro II. Pode-se entender tudo isso, de maneira diversa e em outras palavras que, por não se focarem estritamente nas relações sociais, afastam possíveis sombras de conteúdos e essências nacionais, e lançam luz sobre formas de organização estruturais da seguinte maneira: "como livrar-se do tradicional pejo hierárquico do Brasil, tal como exigência para a expansão democratizante, mas sem aí destruir seus traços estruturais, não menos antigos, que animam a nossa vida social e a distinguem de outros coletivos?"348

Não atentar a essas nuances e controvérsias, essa necessária crise e reflexão sobre nosso processo formativo, ou mesmo querer ignorar esse paradoxo estruturante, talvez impeça o entendimento do relato que Antonio Candido trouxe de uma de suas visitas à região de Rio Bonito - atual Bofete, no interior paulista -, quando para lá fora, no final da década de 1940, realizar trabalho de campo e coletar informações para a elaboração

\footnotetext{
${ }^{347}$ Gilberto Freyre. Ordem e progresso. Op. cit, p. 231-232.

${ }^{348}$ Stelio Marras. "Entre o êxito e a hesitação: pensamento e militância de Sérgio Buarque de Holanda". In: Stelio Marras (org.). Atualidade de Sérgio Buarque de Holanda. Op. cit, p. 10. Acerca dos "traços estruturais", ver, por exemplo: Claude Lévi-Strauss. "A noção de estrutura em etnologia". In: Antropologia estrutural. Op. cit., pp. 400-401.
} 
de sua tese Os parceiros do Rio Bonito. Trata-se de uma breve conversa com um caipira local, conhecido como nhô Samuel:

Quem esteve em contacto com ele sabe, por exemplo, o quanto é impreciso sobre sua própria idade e como não consegue pôr datas na lembrança, além de não saber o que se passa na sociedade maior, cujos sinais podem estar ao seu lado sob a forma de jornal que ele não lê, de cinema que não vê, de rádio que não escuta, de trem que não toma. "Como vai o imperador?", perguntou-me em 1948 o nonagenário nhô Samuel Antônio de Camargo, nascido no Rio Feio, atual Porangaba. "Vai bem", respondi. E ele, com uma dúvida: "Mas não é mais aquele veião de barba?". E eu: "Não, agora é outro, chamado Dutra" ${ }^{349}$.

Esse caso permite constatar como a memória que se constituiu sobre o segundo imperador foi produtiva e duradoura, assim como os dilemas e riscos que ela traz consigo; a figura do "veião de barba" estava além de seu regime, permanecia, anos depois de sua destituição e morte, uma referência comum, revelando aspectos estruturais, positivos e negativos, de nossa formação. Esta é uma boa exemplificação do dilema: se d. Pedro II, esse imperador pelo qual passam tantas interpretações controversas, trata-se de um governante representativo da história e das controvérsias brasileiras, o verso da moeda é esse nhô Samuel, que, por sua vez, também é significativo da formação nacional. Como diz José Miguel Wisnik, inspirado (e o levando além) por aquele comentário de Fernando Novais acerca de Raízes do Brasil: "o país foi, de certo modo, se modernizando sem deixar de ser Brasil e sendo Brasil sem se modernizar, isto é, entrando de maneira arrevesada numa modernidade compulsória que nem a realiza e nem o realiza [...]". ${ }^{350}$ Talvez seja o caso, então, ao invés de tratar d. Pedro II como estranho - tal como vem na capa da Revista de História da Biblioteca Nacional -, de tomá-lo como uma normalidade da vida política e cultural brasileira. Daí, imagino, seja possível começar a repensar o arranjo que o sustenta; começar a tirar nhô Samuel da sombra do monarca e, ao mesmo tempo, compreender os sentidos que perpassaram a vivência própria do caipira, os significados múltiplos que ele podia dar a esse tal veião de barba.

Dessa forma, e de maneira um tanto diversa, pode ser possível não anular o paradoxo do imperador, mas começar a tratá-lo em outra chave, operá-lo a partir de uma concepção distinta. Nesse sentido, e para finalizar, aí vão mais duas flores. Ambas

\footnotetext{
${ }^{349}$ Antonio Candido. “Caipiradas”, in: Recortes. São Paulo: Companhia das Letras, 1996, p. 250.

${ }^{350}$ José Miguel Wisnik. Veneno remédio: o futebol e o Brasil. São Paulo: Companhia das Letras, 2008, pp. 418-419.
} 
revelam as possibilidades que d. Pedro II ainda nos oferece. São dois poemas de Murilo Mendes, os dois presentes no mesmo livro, publicado em 1932:

\author{
O brasileiro D. Pedro II \\ ou \\ No Brasil não há pressa \\ Uma vasta sonolência \\ Invade toda a fazenda. \\ Sucedem-se os ministérios, \\ As guerrilhas se sucedem \\ Pro povo se divertir. \\ A corte faz pic-nics, \\ Ou organiza quadrilhas \\ Nos bailaricos reais. \\ A Inglaterra intervém \\ No mercado das finanças, \\ Todos acham muito bom. \\ Houve entrudos famosíssimos... \\ O imperador, de pijama, \\ Lê o Larousse na rede \\ O fato é que com essa calma \\ Cinquenta anos se aguentou.
}

\section{Glória de D. Pedro II}

Um anjo de sobrecasaca, de [chinelas,

Passou matutando no ar:

A terra não é mais uma colônia, Os estadistas caem que nem cocos. As máquinas serão soltas em 1988, O homem ficará lendo seus

No jardim onde tanks [livrinhos Já terão passado.

Os soldados serão presos pra sempre Num cavalo de aço, não é de pau. Aos domingos terá retreta para eles, Começando pela protofonia do

Os ditadores de pijama [Guarani.

Virão comer pé de moleque Com o povo.

Flores com espinhos e sem espinhos, nascidas no mesmo canteiro, dividindo as páginas do mesmo livro; uma obra, tão sugestivamente, intitulada História do Brasil. ${ }^{351}$ A pena do excepcional poeta não deixa mentir o paradoxo, muito menos a atualidade do personagem; pela via da sátira, coisa tão comum quando se trata de d. Pedro II, revela mais um duplo, marcado por desencanto e potencialidade. Deixa nítidas nossas deficiências e possibilidades, nossa raiz funda, "rija de febra e seiva"; faz emergir, novamente, risco e produtividade, ambos constituintes de nossa formação. Torna evidente a riqueza e os dilemas da história e da memória. Mas que sobressaia, afinal, uma nota de esperança: dos legados do imperador, oxalá se supere a tal falta de pressa, e que seja essa "glória de d. Pedro II" o que subexista. Que, algum dia, finalmente, se realize, de forma plena, essa festa embalada a pé de moleque.

\footnotetext{
${ }^{351}$ Murilo Mendes. História do Brasil. Organização, introdução e notas de Luciana Stegagno Picchio. Rio de Janeiro: Nova Fronteira, 1991, p. 48 e p. 83.
} 


\section{Agradecimentos}

Muitas pessoas e instituições, direta ou indiretamente, participaram da elaboração e realização desta pesquisa. A eles e elas, faço meus agradecimentos.

À Coordenação de Aperfeiçoamento de Pessoal de Nível Superior (CAPES), pela bolsa concedida entre maio de 2012 e maio de 2014 .

Aos professores do IEB, em especial a querida Ana Paula Cavalcanti Simioni, professora que, desde o princípio, com sua atenção, argúcia e simpatia, foi imprescindível para a efetivação deste trabalho; o Fernando Paixão, com quem tive a gratificante experiência de realizar o estágio do PAE; o Alexandre de Freitas Barbosa, por me abrir os olhos aos temas da economia; e o Paulo Teixeira Iumatti, por tão atenciosamente ter aceito participar da banca de defesa.

À professora Monica Duarte Dantas, também do IEB, e à Lilia M. Schwarcz, pelas críticas e comentários feitos durante o exame de qualificação.

À Cristina e todo pessoal que trabalhou na Secretaria de Pós-Graduação nesses últimos anos - Carolina, Henrique, Gislene, Rafael e Daniele -, pela dedicação e, sobretudo, pela enorme paciência com meus esquecimentos e irresponsabilidades.

Aos funcionários da Biblioteca Florestan Fernandes (FFLCH/USP), da Biblioteca do Instituto de Estudos Brasileiros, da Biblioteca Central da Faculdade de Direito do Largo São Francisco, da Biblioteca Municipal Mário de Andrade, da Biblioteca Municipal Sérgio Milliet e da Biblioteca da Academia Paulista de Letras; a todos agradeço através da exemplar senhora Maria Luísa, bibliotecária da APL, cujo empenho e simpatia foram notáveis.

Ao Stelio A. Marras que, orientador desta pesquisa, me acompanhou pelas sendas tortuosas da interdisciplinaridade, sempre colocando problemas novos e provocando reflexões inesperadas; sempre compartilhando minhas dúvidas e incentivando meus devaneios. Acima de tudo isso, fica a marca da sincera amizade.

Aos amigos de Bragança, que há tanto tempo me ouvem falar desse mestrado. Abraço especial para o Danilo Serpa, colega de longa data, com quem compartilho muito de minha trajetória. 
Aos amigos de São Paulo, sobretudo os dois Guilhermes: o Rodrigues Leite, com quem cada encontro é sempre um prazer e um aprendizado; e o Pacheco, colega de mestrado e inquietações, com quem tive saudosas conversas no jardim em frente ao antigo IEB.

Aos meus irmãos Pablo e Thiago, companheiros de vida e de casa - a Vanessa também.

Às minhas irmãs Alexandra e Amanda, as duas pontas de uma história que, para minha imensa sorte, é bastante confusa e repleta das mais variadas pessoas.

À Lorena, família que escolhi (e, claro, pela ajuda com o espanhol e com as tramas da academia).

À Tânia, minha mãe, pela sua sabedoria que tanto me espanta e faz pensar.

Ao José de Nicola, meu pai e professor, por ter me ensinado grande parte do que eu sei (e por ter sido, desde sempre, incansável comentador, revisor, incentivador, debatedor e tudo o mais que envolve esta pesquisa).

Enfim, à Alice, por tudo que passou e por tudo que virá. Foi ela quem mais me aturou e inspirou ao longo de todo esse período (tanto é que, talvez, eu lhe deva, na mesma proporção, agradecimentos e desculpas). Ela, historiadora também, quem me ensina a pensar e questionar, todos os dias, os dois lados da questão: a dificuldade do ofício e o risco do saber apático. O mais que há por ser dito, direi a sós - fica para o reservado de nós dois. 


\section{BIBLIOGRAFIA}

ABREU, Capistrano de. Ensaios e estudos: crítica e história, $3^{a}$ série. Nota liminar de José Honório Rodrigues. Rio de Janeiro: Civilização Brasileira; Brasília: INL, 1976.

ABREU, Capistrano de. Capítulos de história colonial (1500-1800). Edição anotada e prefaciada por José Honório Rodrigues. Belo Horizonte: Itatiaia; São Paulo: Publifolha, 2000 (Coleção Grandes nomes do pensamento brasileiro).

ABREU, Regina. A fabricação do imortal: memória, história e estratégias de conservação no Brasil. Rio de Janeiro: Rocco: Lapa, 1996.

ALONSO, Angela. Ideias em movimento: a geração de 1870 na crise do BrasilImpério. São Paulo: Paz \& Terra, 2002.

ANDRADE, Mário de. Os filhos da Candinha. Rio de Janeiro: Agir, 2008.

ANDRADE, Oswald de. Pau-Brasil. São Paulo: Globo, 1991.

ARANTES, Paulo Eduardo. Zero à esquerda. São Paulo: Conrad, 2004 (Coleção Baderna).

ARAÚJO, Maria Paula Nascimento \& SANTOS, Myrian Sepúlveda dos. "História, memória e esquecimento: Implicações políticas", Revista Crítica de Ciências Sociais [Online], 79, 2007, pp. 95-111.

ARAÚJO, Ricardo Benzaquen de. Guerra e paz: Casa-grande \& senzala e a obra de Gilberto Freyre nos anos 30. São Paulo; Editora 34, 1994.

ARENDT, Hannah. Eichmann em Jerusalém: um relato sobre a banalidade do mal. Tradução de José Rubens Siqueira. São Paulo: Companhia das Letras, 1999.

ASSIS, Machado de. Esaú e Jacó. São Paulo: Ática, 1996.

AZEREDO, Carlos Magalhães de. Dom Pedro II. Traços de sua physionomia moral. Rio de Janeiro: Álvaro Pinto, editor, 1923.

AZEREDO, Carlos Magalhães de. Memórias. Transcrição, atualização ortográfica e introdução de Afonso Arinos, filho. Rio de Janeiro: Academia Brasileira de Letras, 2003.

BARMAN, Roderick J. Imperador cidadão e a construção do Brasil. Tradução de Sonia Midori Yamamoto. São Paulo: Ed. UNESP, 2012.

BORGES, Jorge Luis. Obras de Jorge Luis Borges. Volume 2. Tradução de Joseny Vianna Baptista et alli. São Paulo: Globo, 1999.

BOSI, Alfredo. Dialética da colonização. São Paulo: Companhia das Letras, 1992.

BOSI, Eclea. O tempo vivo da memória: ensaios de psicologia social. São Paulo: Ateliê Editorial, 2003.

BOTELHO, André \& SCHWARCZ, Lilia (orgs.). Um enigma chamado Brasil: 29 intérpretes e um país. São Paulo: Companhia das Letras, 2009.

BRANDÃO, Gildo Marçal. "Linhagens do pensamento político brasileiro", In: Dados Revista de Ciências Sociais, Rio de Janeiro, Vol. 48, n² 2, 2005 (texto consultado em www.scielo.com.br).

BRITO, Mário da Silva. História do modernismo brasileiro: antecedentes da Semana de Arte Moderna. Rio de Janeiro: Civilização Brasileira, 1978. 
CALDEIRA, Jorge. Mauá: empresário do Império. São Paulo: Companhia das Letras, 1995.

CALMON, Pedro. O rei filósofo: a vida de D. Pedro II. Rio de Janeiro: Companhia Editora Nacional, 1938 (Coleção Brasiliana, vol. 120).

CALMON, Pedro. A vida de D. Pedro II, o rei filósofo. Edição especial comemorativa do sesquicentenário de seu nascimento. Rio de Janeiro: Biblioteca do Exército, 1975.

CAMPOS, Paulo Mendes. Brasil Brasileiro. Rio de Janeiro: Civilização Brasileira, 2005

CAMPOS, Paulo Mendes. Alhos e bugalhos: crônicas humorísticas. Rio de Janeiro: Civilização Brasileira, 2006.

CANDIDO, Antonio. Literatura e Sociedade. São Paulo: Companhia Editora Nacional, 1965.

CANDIDO, Antonio. Recortes. São Paulo: Companhia das Letras, 1996.

CARDOSO, Vicente Licínio. À margem da história do Brasil. São Paulo: Editora Nacional, 1979 (Coleção Brasiliana: vol. 13).

CARVAlHO, José Murilo de. Os bestializados. São Paulo: Companhia das Letras, 1987.

CARVALHO, José Murilo de. Cidadania no Brasil: o longo caminho. Rio de Janeiro: Civilização Brasileira, 2003.

CARVALHO, José Murilo de. "Introdução". In: VIANNA, Oliveira. O ocaso do Império. Rio de Janeiro: Academia Brasileira de Letras, 2006, pp. IX-XXI.

CARVAlHO, José Murilo de. A formação das almas. São Paulo: Companhia das Letras, 2007.

CARVAlHO, José Murilo de. D. Pedro II: ser ou não ser. São Paulo: Companhia das Letras, 2007.

CARVALHO, José Murilo de. A construção da ordem: a elite política imperial. Teatro das sombras: a política imperial. Rio de Janeiro: Civilização Brasileira, 2012.

CARVALHO, José Murilo de (Coord). A construção nacional (1830-1889) - volume 2. Rio de Janeiro: Objetiva; Madri: Fundación Mapfre, 2012.

CERTEAU, Michel de. A escrita da história. Tradução de Maria de Lourdes Menezes. Revisão técnica de Arno Vogel. Rio de Janeiro: Forense Universitária, 2007.

COPI. Eva Perón. Traducción de Jorge Monteleone. Buenos Aires: Adriana Hidalgo Editora, 2000.

COSTA, João Cruz. Pequena história da República. São Paulo: Brasiliense, 1989.

COSTA, Emília Viotti da. Da monarquia à República. São Paulo: Ed. UNESP, 2007.

COSTA, Emília Viotti da. A abolição. São Paulo: Ed. UNESP, 2008.

D. PEDRO II. Poesias completas de d. Pedro II. Prefácio de Medeiros e Albuquerque. Rio de Janeiro: Editora Guanabara, 1932.

DAMATTA, Roberto. Carnavais, malandros e heróis: para uma sociologia do dilema brasileiro. Rio de Janeiro: Rocco, 1997.

DANTAS, Monica Duarte (org.). Revoltas, motins, revoluções: homens livres pobres e libertos no Brasil do século XIX. São Paulo: Alameda, 2011. 
DARNTON, Robert. O grande massacre de gatos e outros episódios da história cultural francesa. Tradução de Sonia Coutinho. Rio de Janeiro: Graal, 1986.

DARNTON, Robert. Os dentes falsos de George Washington: um guia não convencional para o século XVIII. Tradução de José Geraldo Couto. São Paulo: Companhia das Letras, 2005.

DUBY, Georges. A história continua. Tradução de Clóvis Marques. Rio de Janeiro: Jorge Zahar; Ed. UFRJ, 1993.

EL FAR, Alessandra. A encenação da imortalidade: uma análise da Academia Brasileira de Letras nos primeiros anos da República (1897-1924). Rio de Janeiro: Editora FGV, 2000.

EULÁLIO, Alexandre. "O ofício de escrever de Heitor Lyra". In: LYRA, Heitor. História de Dom Pedro II. Volume I: Ascensão (1825-1870). Belo Horizonte: Editora Itatiaia; São Paulo: Edusp, 1977, pp. I-IX.

EULÁLIO, Alexandre. Tempo reencontrado: ensaios sobre arte e literatura. Organização de Carlos Augusto Calil. São Paulo: Instituto Moreira Salles; Editora 34, 2012.

FAGUNDES, Luciana Pessanha. "Memórias da monarquia: D. Pedro II no cenário político da década de 20". Anais do XIX Encontro Regional de História: Poder, Violência e Exclusão. ANPUH/SP-USP. São Paulo, 08 a 12 de setembro de 2008. Disponível no site: http://www.anpuhsp.org.br/sp/downloads/CD\%20XIX/PDF/Autores\%20e\%20Art igos/Luciana\%20Pessanha\%20Fagundes.pdf (Consultado em 03/09/2013).

FAGUNDES, Luciana Pessanha. "Entre comemorações, rituais e passados construídos: a Monarquia sob o olhar da Primeira República". Seminário cultura e política na Primeira República: Campanha Civilista na Bahia. UESC, 2010. Disponível no site: $\quad$ http://www.uesc.br/eventos/culturaepolitica/anais/lucianafagundes.pdf (Consultado em 03/09/2013)

FAUSTO, Boris. História geral da civilização brasileira - vols. 8 a 11. São Paulo: Difusão européia de livros, 1985/86.

FAUSTO, Boris. História do Brasil. São Paulo: Edusp, 2008.

FAUSTO, Boris. Getúlio Vargas: o poder e o sorriso. São Paulo: Companhia das Letras, 2006.

FLEIUSS, Max. Dom Pedro Segundo. Rio de Janeiro: Imprensa Nacional, 1940.

FONSECA, Rubem. O selvagem da ópera. São Paulo: Companhia das Letras, 1994.

FREYRE, Gilberto. Perfil de Euclides e outros perfis. Rio de Janeiro: Record, 1987.

FREYRE, Gilberto. Manifesto regionalista. Organização e apresentação Fátima Quintas. Prefácio de Antônio Dimas. Recife: FUNDAJ, Editora Massangana, 1996.

FREYRE, Gilberto. Sobrados \& Mucambos: decadência do patriarcado rural e desenvolvimento urbano. Apresentação de Roberto DaMatta. São Paulo: Global, 2003. 
FREYRE, Gilberto. Nordeste; aspectos da influência da Cana sobre a Vida e a Paisagem do Nordeste do Brasil. Apresentação de Manoel Correia de Andrade. São Paulo: Global, 2004.

FREYRE, Gilberto. Ordem e progresso. Apresentação de Nicolau Sevcenko. São Paulo: Global, 2004.

FREYRE, Gilberto. Casa grande \& senzala: formação da família brasileira sob o regime da economia patriarcal. Apresentação de Fernando Henrique Cardoso. São Paulo: Global, 2006.

FREYRE, Gilberto. Vida social no Brasil nos meados do século XIX. São Paulo: Global, 2009.

FREYRE, Gilberto. Em torno de Joaquim Nabuco. Organização de Edson Nery da Fonseca. São Paulo: A Girafa, 2010.

FURTADO, Celso. Formação econômica do Brasil. São Paulo: Companhia Editora Nacional, 1998.

GAY, Peter. O estio na história: Gibbon, Ranke, Macaulay e Burckhardt. Tradução de Denise Bottmann. São Paulo: Companhia das Letras, 1990.

GINZBURG, Carlo. O fio e os rastros. Tradução: Rosa Freire d'Aguiar e Eduardo Brandão. São Paulo: Companhia das Letras, 2007.

GOMES, Angela de Castro. A República, a História e o IHGB. Belo Horizonte: Argvmentvm, 2009.

GRYZINSKY, Vilma. “O rei e nós”. In: Veja, edição n 2034, 14 de novembro de 2007, pp. 109-119.

HALBWACHS, Maurice. La mémoire collective. Édition critique établie par Gérard Namer. Paris: Éditions Albin Michel, 1997 (Bibliothèque de 'L'Évolution de l'Humanité, 28).

HALBWACHS, Maurice. A memória coletiva. Tradução de Beatriz Sidou. São Paulo: Centauro, 2006.

HOBSBAWM, Eric J. Ecos da Marselhesa: dois séculos reveem a Revolução Francesa. Tradução de Maria Celia Paoli. São Paulo: Companhia das Letras, 1996.

HOBSBAWM, Eric J. A era dos impérios (1875-1914). Tradução de Sieni Maria Campos e Yolanda Steidel de Toledo. São Paulo: Paz \& Terra, 2007.

HOLANDA, Sérgio Buarque de. História geral da civilização brasileira - vols. 3 a 7 . São Paulo: Difusão européia de livros, 1985/86.

HOLANDA, Sérgio Buarque de. Raizes do Brasil. São Paulo: Companhia das Letras, 1997.

HOLANDA, Sérgio Buarque de. Capitulos de história do Império. São Paulo: Companhia das Letras, 2010.

HOLANDA, Sérgio Buarque de. Sérgio Buarque de Holanda: escritos coligidos, livro I (1920-1949). Organização de Marcos Costa. São Paulo: Ed. UNESP; Fundação Perseu Abramo, 2011.

IGLESIAS, Francisco. História e Literatura. São Paulo: Perspectiva, 2009. 
KANTOROWICZ, Ernest Hartwig. Os dois corpos do rei: um estudo sobre teologia política medieval. Tradução de Cid Knipel Moreira. São Paulo: Companhia das Letras, 1998.

KOSELLECK, Reinhart. Futuro passado: contribuição à semântica dos tempos históricos. Rio de Janeiro: Contraponto: Ed. PUC-Rio, 2006.

LAFER, Celso. A reconstrução dos direitos humanos: um diálogo com o pensamento de Hannah Arendt. São Paulo: Companhia das Letras, 1988.

LAFETÁ, José Luiz. 1930: a crítica e o modernismo. São Paulo: Duas Cidades, 1974.

LATOUR, Bruno. Jamais fomos modernos: ensaio de antropologia simétrica. Tradução de Carlos Irineu da Costa. Rio de Janeiro: Editora 34, 1994.

LAVABRE, Marie-Claire. "Usages du passé, usages de la mémoire". In: Revue française de science politique. 44e année, $\mathrm{n}^{\circ} 3$, 1994, pp. 480-493. Colsultado no site: $\quad$ http://www.persee.fr/web/revues/home/prescript/article/rfsp 003529501994 num $44 \quad 3 \quad 394841$

LAVABRE, Marie-Claire. "Usage et mésusage de la notion de mémoire". In: Critique internationale. Année 2000, Vol. 7, Num. 7, pp. 48-57. Consultado no site: http://www.persee.fr/web/revues/home/prescript/article/criti_12907839_2000_nu m7 11560

LE GOFF, Jacques. História e memória. Campinas: Editora da Unicamp, 2003.

LEVINE, Robert M. Pai dos pobres? O Brasil e a era Vargas. Tradução de Anna Olga de Barros Barreto. São Paulo: Companhia das Letras, 2001.

LÉVI-STRAUSS, Claude. Antropologia estrutural. Tradução de Beatriz PerroneMoisés. São Paulo: Cosac \& Naify, 2012 (Coleção Portátil, 10).

LIMA, Oliveira. O Império brasileiro (1822-1889). Brasília: Editora Universidade de Brasilia, 1986.

LIMA, Oliveira. Formação histórica da nacionalidade brasileira. Rio de Janeiro: Topbooks; São Paulo: Publifolha, 2000 (Coleção Grandes nomes do pensamento brasileiro).

LLOSA, Mario Vargas. A verdade e as mentiras. São Paulo: ARX, 2004.

LOBATO, Monteiro. Ideias de Jeca Tatu. São Paulo: Globo, 2008.

LOBATO, Monteiro. Na antevéspera. São Paulo: Globo, 2008.

LOUIS, Moreau de Bellaing. "Mémoires de la mémoire : la commémoration". In: L Homme et la société, N. 75 76, 1985. Synthèse en sciences humaines. pp. 237244. Consultado no site: http://www.persee.fr/web/revues/home/prescript/article/homso_00184306_1985_ num $75 \quad 1 \_2200$

LOWENTHAL, David. "Como conhecemos o passado". In: Revista Projeto História, PUC/SP, no 17, nov. 1998, pp.63-104.

LYRA, Heitor. História de Dom Pedro II. Volume I: Ascensão (1825-1870). Rio de Janeiro: Companhia Editora Nacional, 1938 (Coleção Brasiliana, vol. 133).

LYRA, Heitor. História de Dom Pedro II. Volume II: Fastígio (1870-1880). Rio de Janeiro: Companhia Editora Nacional, 1939 (Coleção Brasiliana, vol. 133-A). 
LYRA, Heitor. História de Dom Pedro II. Volume III: Declínio (1880-1891). Rio de Janeiro: Companhia Editora Nacional, 1940 (Coleção Brasiliana, vol. 133-B).

MACEDO, Valéria. "Os impérios da festa: a festa do divino no Rio de Janeiro do XIX"; In: Sexta Feira, número 2, ano 2, abril de 1998, pp. 84-95.

MAGAlHÃES, Domingos Gonçalves de. A Confederação dos Tamoios. Organizado por Maria Eunice Moreira e Luís Bueno. Curitiba: Editora UFPR, 2007.

MARTINS, Luís. O patriarca e o bacharel. São Paulo: Alameda, 2008.

MARRAS, Stelio (org.). Atualidade de Sérgio Buarque de Holanda. São Paulo: Edusp, Instituto de Estudos Brasileiros, 2012.

MARTÍNEZ, Tomás Eloy. Santa Evita. Tradução de Sérgio Molina. São Paulo: Companhia das Letras, 1996.

MARTIUS, Carl F. P. von. "Como se deve escrever a história do Brasil". In: O estado do direito entre os autóctones do Brasil. Belo Horizonte: Ed. Itatiaia.

MARX, Karl \& ENGELS, Friedrich. A ideologia alemã. Tradução: Álvaro Pina. São Paulo: Expressão Popular, 2009.

MAURO, Frédéric. O Brasil no tempo de dom Pedro II (1831-1889). Tradução de Tomás Rosa Bueno. São Paulo: Companhia das Letras / Círculo do Livro, 1991.

MENDES, Murilo. Poemas e Bumba-meu-poeta. Rio de Janeiro: Nova Fronteira, 1988.

MENDES, Murilo. História do Brasil. Organização, introdução e notas de Luciana Stegagno Picchio. Rio de Janeiro: Nova Fronteira, 1991.

MENDES, Murilo. Poesia completa e prosa, volume único. Organização e preparação do texto: Luciana Stegagno Picchio. Rio de Janeiro: Nova Aguiar, 1994.

MENDONÇA, Carlos Sussekind de. Quem foi Pedro II: golpeando, de frente, o saudosismo. Recife: Livraria Brandão, 1929.

MENESES, Ulpiano Toledo Bezerra de. "Do teatro da memória ao laboratório da História: a exposição museológica e o conhecimento histórico". In: Anais do Museus Paulista: história e cultura material. São Paulo, v. 2, 1994, pp. 9-42.

MEYNIER, Gilbert. "Les historiens et la mémoire après Halbwachs et Freud". In: Insaniyat [En ligne], 39-40, 2008, mis en ligne le 30 juin 2012, consulté le 03 septembre 2013. URL : http://insaniyat.revues.org/1880

MICELI, Sergio. Poder, sexo e letras na República Velha. São Paulo: Perspectiva, 1977.

MICELI, Sergio. "Por uma sociologia das Ciências Socais". In: MICELI, Sergio (org.). História das Ciências Sociais - vol. I. São Paulo: Vértice, Editora Revista dos Tribunais: IDESP, 1989, pp. 5-19.

MOREAU DE BELLAING, Louis. "Mémoires de la mémoire : la commémoration". In: L'Homme et la société, n. 75-76, 1985. Synthèse en sciences humaines. pp. 237$244 . \quad$ Disponível no site: http://www.persee.fr/web/revues/home/prescript/article/homso_00184306 1985 num 75_1_2200 (Consultado em 03/09/2013).

MOTA, Carlos Guilherme. Ideologia da cultura brasileira (1933-1974): pontos de partida para uma revisão histórica. São Paulo: Editora 34, 2008.

NABUCO, Joaquim. O abolicionismo. Rio de Janeiro: BestBolso, 2010. 
NABUCO, Joaquim. Minha formação. Apresentação de Alfredo Bosi. São Paulo: Editora 34, 2012.

NORA, Pierre (org). Les lieux de mémoire. Tome 1: La République. Paris: Éditions Gallimard, 1984.

NOVAIS, Fernando A. (coord.) \& SCHWARCZ, Lília M. (org.). História da vida privada no Brasil: contrastes da intimidade contemporânea. São Paulo: Companhia das Letras, 1998 (História da vida privada no Brasil, v. 4).

NOVAIS, Fernando. Aproximações: ensaios de história e historiografia. São Paulo: Cosac \& Naify, 2005.

OCTAVIO, Rodrigo. Minhas memórias dos outros. Primeira Série. Rio de Janeiro: Civilização Brasileira; Brasília: INL, 1978 (Coleção Relatos do Brasil; v. 119).

ODÁLIA, Nilo. As formas do mesmo. São Paulo: Ed. UNESP. 1997.

PAES, José Paulo. Um por todos: poesia reunida. Introdução de Alfredo Bosi. São Paulo: Brasiliense, 1986.

PAES, José Paulo. Armazém literário: ensaios. Organização de Vilma Arêas. São Paulo: Companhia das Letras, 2008.

PANOFSKY, Erwin. Renacimiento y renacimientos en el arte occidental. Madrid: Alianza Universidad, 1994.

PERLONGHER, Néstor. Evita vive e outras prosas. Tradução de Joseny Vianna Baptista. São Paulo: Iluminuras, 2001.

PIGLIA, Ricardo. O laboratório do escritor. Tradução de Josely Vianna Baptista. São Paulo: Iluminuras, 1994.

PINTO, Júlio Pimentel. Uma memória do mundo: ficção, memória e história em Jorge Luis Borges. Prefácio de Maria Angela Ligia Coelho Prado. São Paulo: Estação Liberdade: FAPESP, 1998.

PINTO, Júlio Pimentel. A leitura e seus lugares. São Paulo: Estação Liberdade, 2004.

POMPÉIA, Raul. O Ateneu / As jóias da coroa. Introdução e comentário: José De Nicola. São Paulo: Ed. Scipione, 1995.

PRADO JÚNIOR, Caio. História econômica do Brasil. São Paulo: Brasiliense, 1981.

PRADO, Paulo. Retrato do Brasil: ensaio sobre a tristeza brasileira. Organização de Carlos Augusto Calil. São Paulo: Companhia das Letras, 2012.

QUEIROZ, Suely Robles Reis de. Política e cultura no Império brasileiro. São Paulo: Brasiliense, 2010.

REGO, José Lins do. Ligeiros traços: escritos de juventude. Seleção, introdução e notas de César Braga-Pinto. Rio de Janeiro: José Olympio, 2007.

REIS, José Carlos. As identidades do Brasil: de Varnhagen a FHC. Rio de Janeiro: Editora FGV, 2005.

RENOIR, Jean. O passado vivo. Tradução de Raquel Ramalhete. Rio de Janeiro: Nova Fronteira, 1991.

Revista de História da Biblioteca Nacional. Ano 8, número 86, Rio de Janeiro, novembro de 2012.

RIBEIRO, Renato Janine. A sociedade contra o social: o alto custo da vida pública no Brasil. São Paulo: Companhia das Letras, 2000. 
RICOEUR, Paul. A memória, a história, o esquecimento. Tradução de Alain François et al. Campinas: Editora da Unicamp, 2007.

ROSSI, Paolo. O passado, a memória e o esquecimento: seis ensaios da história das ideias. Tradução de Nilson Moulin. São Paulo: Editora UNESP, 2010.

SAHLINS, Marshall. Ilhas de história. Tradução de Bárbara Sette. Rio de Janeiro: Zahar, 2011.

SAHLINS, Marshall. Esperando Foucault, ainda. Tradução de Marcela Coelho de Souza e Eduardo Viveiros de Castro. São Paulo: Cosac \& Naify, 2013 (Coleção Portátil, 17).

SANCHES NETO, Miguel. A máquina de madeira. São Paulo: Companhia das Letras, 2012.

SARLO, Beatriz. Paisagens imaginárias: Intelectuais, Arte e Meios de Comunicação. Tradução de Rubia Prates Goldoni e Sérgio Molina. São Paulo: Edusp, p. 2005. (Ensaios Latino-americanos: 2)

SARLO, Beatriz. A paixão e a exceção: Borges, Eva Perón, Montoneros. Tradução de Rosa Freire d'Aguiar, Heloisa Jahn, José Marcos Macedo, Rubia Prates Goldoni e Sérgio Molina. São Paulo: Companhia das Letras; Belo Horizonte: Editora UFMG, 2005.

SARLO, Beatriz. Tempo passado: cultura da memória e guinada subjetiva. Tradução de Rosa Freire d'Aguiar. São Paulo: Companhia das Letras; Belo Horizonte: UFMG, 2007.

SARTRE, Jean-Paul. Que é a literatura? São Paulo: Ed. Ática, 2004.

SCHORSKE, Carl E. Pensando com a história: indagações na passagem para o modernismo. Tradução de Pedro Maia Soares. São Paulo: Companhia das Letras, 2000 .

SCHWARCZ, Lilia M. \& ANGELI. Cai o Império! República vou ver! São Paulo: Brasiliense, 1983.

SCHWARCZ, Lilia M. As barbas do imperador. São Paulo: Companhia das Letras, 2008.

SCHWARCZ, Lilia M. O espetáculo das raças: cientistas, instituições e questão racial no Brasil (1870-1930). São Paulo: Companhia das Letras, 2007.

SCHWARCZ, Lilia M. D. Pedro II e seu reino tropical. São Paulo: Claro enigma, 2009.

SCHWARCZ, Lilia M. (coord.) A abertura para o mundo: 1889-1930. Rio de Janeiro: Objetiva, 2012.

SCHWARZ, Roberto. Ao vencedor as batatas: forma literária e processo social nos inícios do romance brasileiro. São Paulo: Editora 34, 2000.

SEVCENKO, Nicolau. Pindorama revisitada: cultura e sociedade em tempos de virada. São Paulo: Peirópolis, 2000 (Série Brasil cidadão).

SEVCENKO, Nicolau. Literatura como missão. São Paulo: Companhia das Letras, 2003.

SINGER, André. Os sentidos do lulismo: reforma gradual e pacto conservador. São Paulo, 2012. 
SODRÉ, Nelson Werneck Sodré. Literatura e História no Brasil Contemporâneo. Porto Alegre: Mercado Aberto, 1987.

SODRÉ, Nelson W. Panorama do segundo império. Rio de Janeiro: Ed. Graphia, 1998.

SOUBLIN, Jean. D. Pedro II - o defensor perpétuo do Brasil. Memórias imaginárias do último imperador. Tradução: Rosa Freira d'Aguiar. São Paulo: Paz \& Terra, 1996.

SOUZA, Laura de Mello e. "Idade Média e Época Moderna: fronteiras e problemas". In: Signum, Revista da Associação Brasileira de Estudos Medievais, nº7, 2005, pp. 223-248.

SOUZA, Gilda de Mello e. "O avô presidente". In: Exercícios de leitura. São Paulo: Duas Cidades; Editora 34, 2008.

SUSSEKIND, Flora. Cinematógrafo de letras: literatura, técnica e modernização no Brasil. São Paulo: Companhia das Letras, 1987.

TARDE, Gabriel. Monadologia e Sociologia. Tradução: Paulo Neves. São Paulo: Cosac Naify, 2007.

TEIXEIRA, Ivan. $O$ altar \& o trono: Dinâmica do poder em O alienista. São Paulo: Ateliê; Campinas: Editora da Unicamp, 2010.

VElloso, Monica Pimenta. História \& Modernismo. Belo Horizonte: Autêntica Editora, 2010 (Coleção História \& ... Reflexões, 14).

VENTURA, Roberto. Estilo Tropical: história cultural e polêmicas literárias no Brasil (1870-1914). São Paulo: Companhia das Letras, 1991.

VIANNA, Oliveira. O idealismo da constituição. São Paulo: Companhia Editora Nacional, 1939.

VIANNA, Oliveira. O ocaso do Império. Recife: FUNDAJ, Editora Massangana, 1990.

VIANNA, Oliveira. O ocaso do Império. Rio de Janeiro: Academia Brasileira de Letras, 2006.

WALSH, Rodolfo. Essa mulher e outros contos. Tradução e apresentação de Sérgio Molina e Rubia Prates Goldoni. São Paulo: Editora 34, 2010.

WISNIK, José Miguel. Veneno remédio: o futebol e o Brasil. São Paulo: Companhia das Letras, 2008. 